\section{Pacific Northwest}

National Laboratory

Operated by Battelle for the

U.S. Department of Energy

\title{
RCRA Groundwater Monitoring Plan for Single-Shell Tank Waste Management Area A-AX at the Hanford Site
}

\author{
S. M. Narbutovskih \\ D. G. Horton
}

January 2001

Prepared for the U.S. Department of Energy under Contract DE-AC06-76RL01830 


\title{
DISCLAIMER
}

This report was prepared as an account of work sponsored by an agency of the United States Government. Reference herein to any specific commercial product, process, or service by trade name, trademark, manufacturer, or otherwise does not necessarily constitute or imply its endorsement, recommendation, or favoring by the United States Government or any agency thereof, or Battelle Memorial Institute.

\author{
PACIFIC NORTHWEST NATIONAL LABORATORY \\ operated by \\ BATTELLE \\ for the \\ UNITED STATES DEPARTMENT OF ENERGY \\ under Contract DE-AC06-76RLO 1830
}

Printed in the United States of America

Available to DOE and DOE contractors from the

Office of Scientific and Technical Information, P.O. Box 62, Oak Ridge, TN 37831;

prices available from (615) 576-8401.

Available to the public from the National Technical Information Service, U.S. Department of Commerce, 5285 Port Royal Rd., Springfield, VA 22161 


\title{
RCRA Groundwater Monitoring Plan for Single-Shell Tank Waste Management Area A-AX at the Hanford Site
}

\author{
S. M. Narbutovskih \\ D. G. Horton
}

January 2001

Prepared for

the U.S. Department of Energy

under Contract DE-AC06-76RLO 1830

Pacific Northwest National Laboratory

Richland, Washington 99352 


\section{Acronyms}

\begin{tabular}{|c|c|}
\hline AEA & Atomic Energy Act of 1954 \\
\hline AR & averaged replicate \\
\hline ASTM & American Society for Testing and Materials \\
\hline $\mathrm{CC}$ & complexant concentrate \\
\hline $\mathrm{CCW}$ & complex concentrated waste \\
\hline CERCLA & Comprehensive Environmental Response, Compensation, and Liability Act \\
\hline CFR & Code of Federal Regulations \\
\hline CPLX & complexed waste \\
\hline DBP & dibutyl phosphate \\
\hline DOE & U.S. Department of Energy \\
\hline DOE-RL & U.S. Department of Energy, Richland Operations Office \\
\hline DSSF & double-shell slurry feed \\
\hline DST & double-shell tank \\
\hline Ecology & Washington State Department of Ecology \\
\hline EDTA & ethylenediaminetetraacetic acid \\
\hline EPA & U.S. Environmental Protection Agency \\
\hline FSP & field sampling plan \\
\hline HDRL & Hanford defense residual liquid \\
\hline HEDTA & $\mathrm{N}$ (2-hydroxyethyl) ethylenediamine tetra acetate \\
\hline HEIS & Hanford Environmental Information System \\
\hline Kgal & one thousand gallons \\
\hline
\end{tabular}


MEMO monitoring efficiency model

Mgal five million gallons

NCPLX non-complexed waste

OWW organic wash waste

PNNL Pacific Northwest National Laboratory

PTA phosphotungstic acid process

PUREX plutonium-uranium extraction

QAPP quality assurance program plan

QA/QC quality assurance/quality control

RCRA Resource Conservation and Recovery Act

REDOX reduction oxidation

RLS radionuclide logging system

SAP sampling and analysis plan

SST single-shell tank

TBP tributyl phosphate

TOC total organic carbon

TOX total organic halides

TPA Tri-Party Agreement

TSD treatment, storage, and disposal units

$\mathrm{uS} / \mathrm{cm} \quad$ microSiemens per centimeter

WAC Washington (state of) Administrative Code

WHC Westinghouse Hanford Company

WMA Waste Management Area 


\section{Contents}

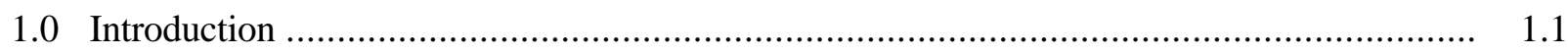

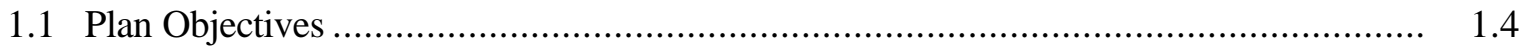

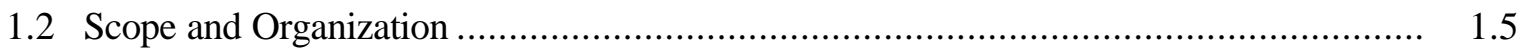

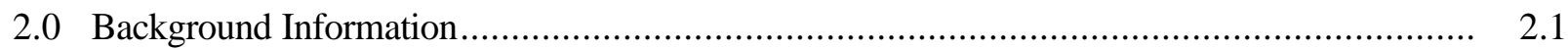

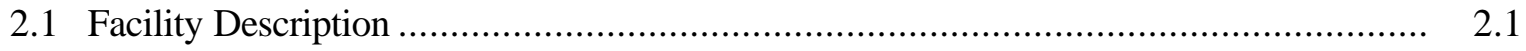

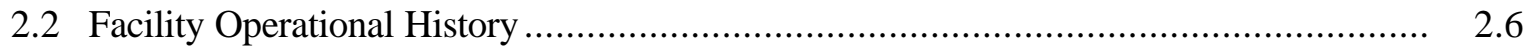





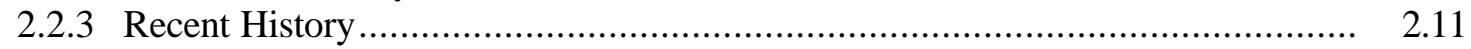

2.3 Waste Characteristics .................................................................................. 2.11

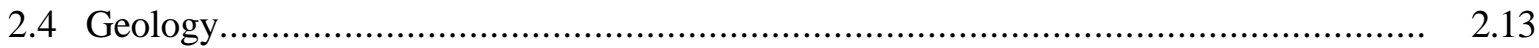

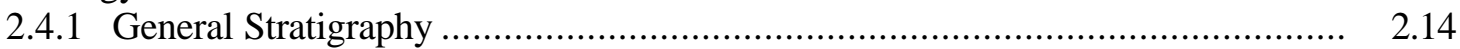



2.4 .3 Aquifer Properties ...................................................................... 2.24

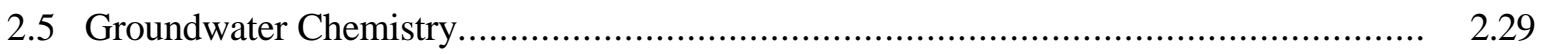

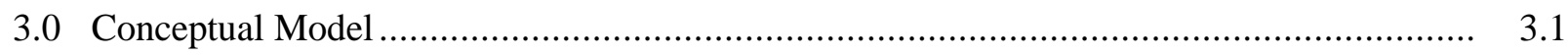

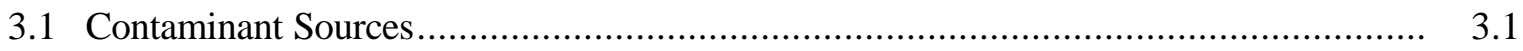

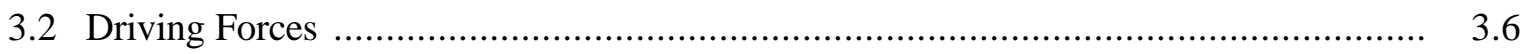

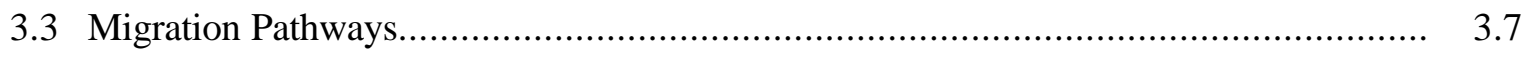



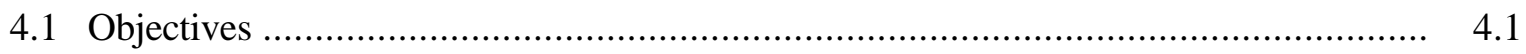

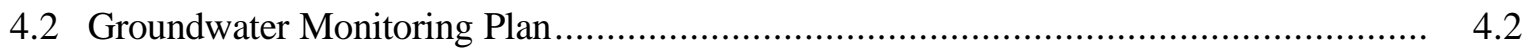

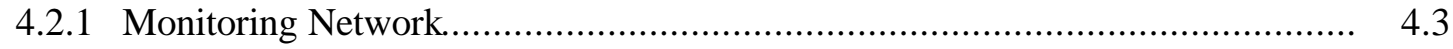

4.2.2 Dangerous Waste Constituents ............................................................. 4.6

4.2.3 Monitoring Issues and Resolutions ..................................................... 4.10

4.2.4 Data Management, Interpretation, and Reporting ....................................... 4.12






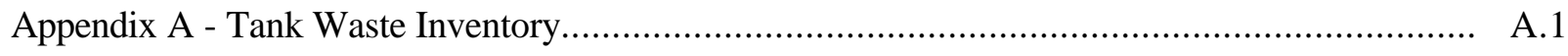

Appendix B - Suggested Approach for First Determination Assessment ............................. B.1

Appendix C - As-Built Diagrams of Single-Shell Tank System Waste Management Area A-AX Groundwater Monitoring Wells .................................................... C. 1

Appendix D - Sampling and Analysis Plan ........................................................ D. 1 


\section{Figures}

1.1 Location of the 200 East Area Within the DOE Hanford Site in Washington State .............. 1.2

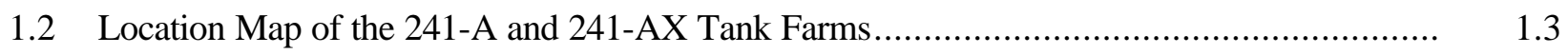

2.1 Schematic Showing the Construction of a Typical Single-Shell Tank with a 1 Million Gal Capacity

2.2 Schematic of the 244-AR Vault, which Consists of Four Smaller Tanks with Dimensions and Storage Capacities as Shown.....................................................................

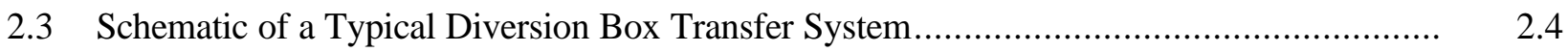

2.4 Map Showing the Locations of Wells and Cross-Sections........................................... 2.16

2.5 Structure Contour Map of the Top of the Ringold Formation ..................................... 2.21

2.6 Structure Contour Map of the Top of the Hanford Formation Sand Sequence .................... 2.23

2.7 Hydrograph Showing Groundwater Elevations Using the NGVD29 Datum, and an Early

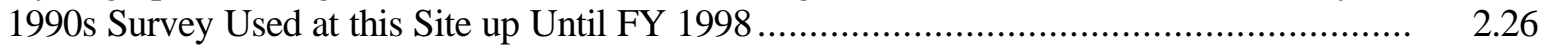

2.8 Hydrograph Showing Groundwater Elevations Referenced to the Datum, NAVD88, and a late 1990s Survey, Except for Well 299-E24-20 ............................................... 2.27

2.9 Trend Plots of Nitrate, Sulfate, and Technetium-99 for WMA A-AX ............................. 2.31

2.10 Trend Plots for Nitrate and Tritium for Well 299-E24-20 Located South of the 244-AR Vault and West of the 241-A Tank Farm........................................................... 2.32

2.11 Trend Plots for Filtered Chromium, Nickel, Manganese, and Iron for Well 299-E24-19 ...... 2.32

2.12 Trend Plots for Well 299-E35-46 Comparing the FY 1997 Data for Technetium-99 and Nitrate

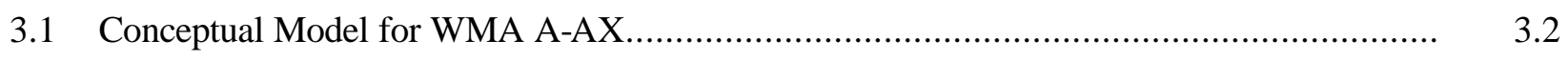

4.1 Series of MEMO Models Used to Evaluate Monitoring Efficiency at WMA A-AX............ 4.7 


\section{Tables}

2.1 Summary Data for Facilities Comprising WMA A-AX ............................................. 2.5

2.2 Tank Leak Volume Estimates .............................................................................

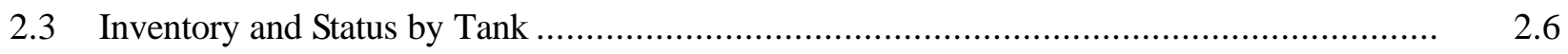

$2.4 \quad$ Sources of Data for Geologic Descriptions ................................................... 2.17

2.5 Data Used to Construct Cross Sections and Structure Contour Maps ............................. 2.20

4.1 Network Monitoring Wells ................................................................................

4.2 Critical Mean Values for the WMA A-AX .........................................................

4.2 Indicator Parameters and Site-Specific Waste Constituents Along with

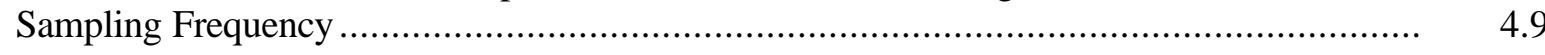

4.4 Reports Required for Compliance with 40 CFR 265, Subpart F, for Groundwater

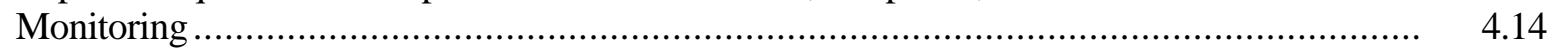




\subsection{Introduction}

This document describes the interim-status groundwater monitoring plan for Waste Management Area (WMA) A-AX. The plan is in accordance with the Resource Conservation and Recovery Act (RCRA) of 1976, as described in 40 Code of Federal Regulations (CFR) 265, Subpart F, by reference of Washington State Administrative Code (WAC) 173-303-400 (3). It is designed to meet interim status requirements for WMA A-AX and replaces the previous plan that included all single-shell tank (SST) WMAs in one document (Caggiano and Goodwin 1991; Jensen et al. 1989). In accordance with requests from U.S. Department of Energy-Richland Operations Office (DOE-RL), separate monitoring plans have been developed for each of the seven WMAs.

Since 1944, radioactive waste has been generated as a byproduct at the DOE Hanford Site during plutonium production for national defense activities (Figure 1.1). Mixed waste (radioactive and dangerous chemical) left from the processing of irradiated fuel rods was stored in 149 underground single-shell tanks since that time. Two single-shell tank farms, 241-A and 241-AX, constitute the WMA A-AX defined for use in developing and operating the groundwater monitoring network. This WMA is located in the 200 East Area of the DOE Hanford Site. The facilities in this WMA are included in the RCRA Dangerous Waste Permit Application, PART A (interim status) submitted in accordance with 40 CFR 265.93. As defined, this WMA may differ from RCRA waste management operable units delineated for remediation under the Comprehensive Environmental Response, Compensation, and Liability Act (CERCLA).

The WMA A-AX consists of six SSTs in 241-A Tank Farm each with a capacity of 1 Mgal $(3,785,000 \mathrm{~L})$ and four SSTs in 241-AX Tank Farm each with a capacity of 1 Mgal $(3,785,000 \mathrm{~L})$ (Figure 1.2). Also included are ancillary equipment consisting of seven diversion boxes, associated piping/diversion stations, valve pits, pumps, and the 244-AR waste transfer vault. The initial groundwater monitoring network was designed for southwest flow and did not include coverage for the 244-AR vault. Recent analysis of the flow direction and inclusion of the 244 -AR vault into the permit dictate that the network be redesigned for current conditions. Tasks required to bring the plan into alignment with current subsurface conditions and the RCRA permit application are identified in this plan.

\section{Current Regulatory Status}

In November 1980, the SSTs were removed from active service and replaced by double-shell tanks (DST) for the receipt of new waste and for transfer of waste from SSTs. Liquid is currently being pumped from various SSTs at the DOE Hanford Site to the DSTs for long-term storage (HNF-EP-0182-131). 


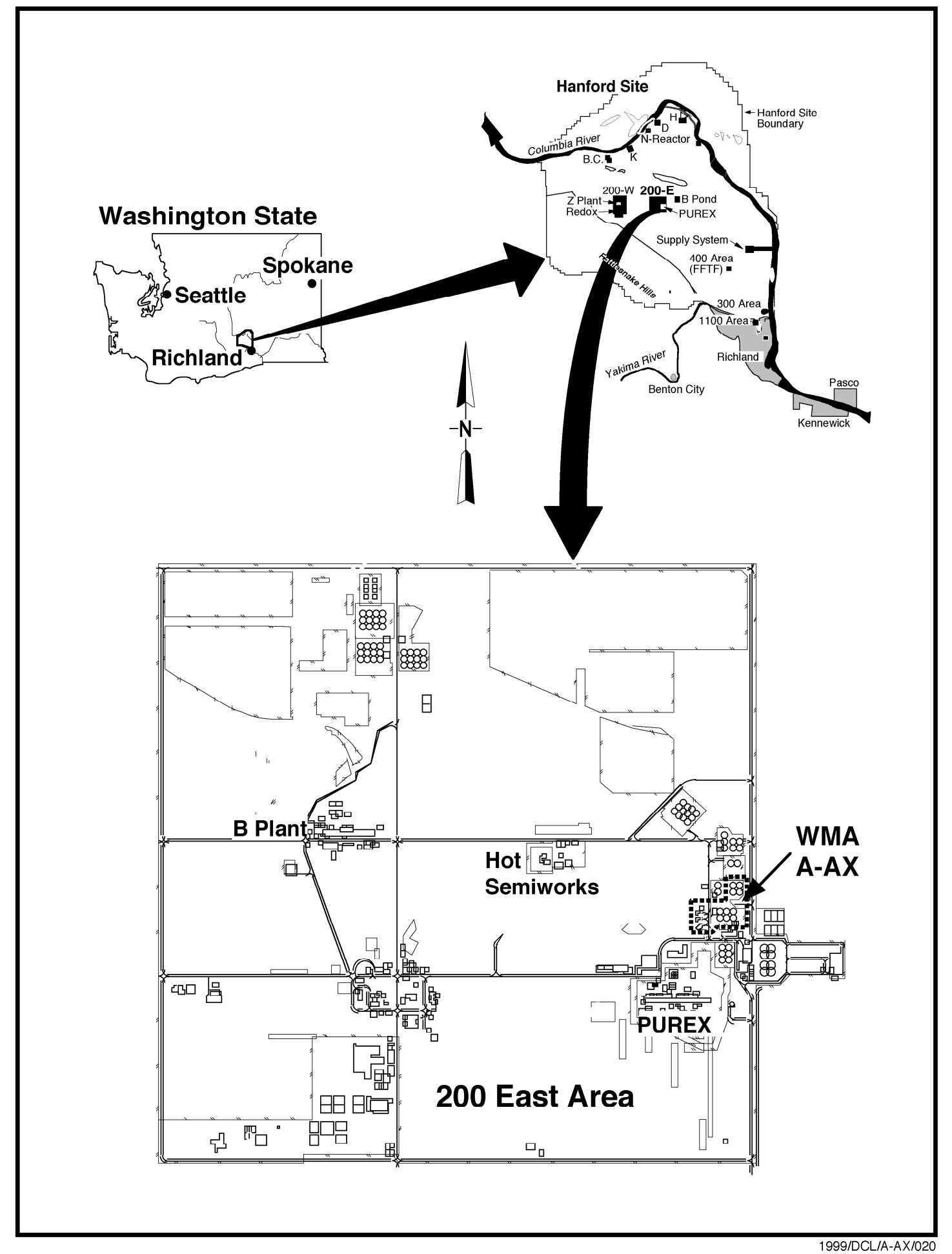

Figure 1.1. Location of the 200 East Area Within the DOE Hanford Site in Washington State 




Figure 1.2. Location Map of the 241-A and 241-AX Tank Farms. These are single-shell tank farms located in the southeast part of the 200 East Area of the Hanford Site. 
In May 1987, DOE issued a final rule (10 CFR 962) stating that the hazardous waste components of radioactive waste, defined as hazardous waste under RCRA, are subject to RCRA regulations. In November 1987, the U.S. Environmental Protection Agency (EPA) authorized the Washington State Department of Ecology (Ecology) to regulate the hazardous component of radioactive mixed waste within the state of Washington (51 FR 24504). Consequently, DOE (radioactive constituents) and Ecology (hazardous chemical constituents) jointly regulate the waste stored in the SSTs.

In May 1989, DOE, EPA and Ecology signed the Tri-Party Agreement (TPA) (Washington State Department of Ecology 1994). This agreement established the roles and responsibilities of the agencies involved in regulating and controlling remedial restoration of the Hanford Site, which includes the SST RCRA WMAs. As part of the RCRA regulatory process, a RCRA Part A (interim status) permit application (DOE/RL-88-21 1996) and closure/work plan (DOE/RL-89-16 1996) have been submitted to Ecology for the SSTs. Although the SSTs are not included in the Hanford Site RCRA permit, the permit application serves as the guidance for groundwater monitoring and delineates specific ancillary equipment (e.g., vaults, diversion boxes) that are included in the WMAs.

\section{Waste Retrieval and Closure Plans}

As a result of negotiating efforts from March to September 1993, DOE, Ecology, and EPA revised the tank waste disposal and closure strategy. Certain aspects of the closure plan affect current and future groundwater monitoring strategies. The plan requires that SST waste be retrieved from the tanks and separated into high-level and low-level radioactive fractions. The low-level radioactive waste will be vitrified, and disposal will be onsite in a manner that does not preclude subsequent retrieval. The vitrified high-level radioactive waste will be sent offsite to a geologic repository. It is also stipulated that the SST farm operable units, including tanks, contaminated soil, and ancillary equipment, will be closed as treatment, storage, and disposal (TSD) units under a single set of regulatory standards pertaining to the hazardous waste constituents (i.e., WAC 173-303, "Dangerous Waste Regulations"). The radioactive constituents continue to be managed in accordance with the Atomic Energy Act (AEA) of 1954. Closure of the SST farms is to be concluded by 2024. In accordance with these long-term goals and regulatory requirements, it is prudent and cost-effective that major modific ations of the groundwater monitoring plan consider both the impacts of waste retrieval on the subsurface and the extended monitoring needs of these closure plans.

\subsection{Plan Objectives}

This revision of the original RCRA groundwater monitoring plan has several goals. First, it is desirable to have separate monitoring plans developed and employed for each SST WMA as opposed to having one encompassing plan. This RCRA monitoring plan is specifically tailored for WMA A-AX. Second, according to the most recent revision to the Part A (interim status) permit application, the 244-AR vault and ancillary equipment have been added to the WMA A-AX system. Coverage of the vault and the ancillary equipment was not included in the original monitoring strategy (Caggiano and Goodwin 1991). This plan provides the groundwork to collect the data needed to design the additional groundwater coverage. Third, based on first determination results of groundwater investigations at four other SST WMAs, it has been shown that the adequacy of current coverage provided by the original 
networks is marginal when the determination of the source of the contamination is required. Also, several RCRA sites have experienced changes in groundwater flow direction in response to the dissipation of the B-Pond and U-Pond mounds. The 200 East Area has a flat water table that makes determination of the hydraulic gradient and flow direction difficult. This plan contains a course of action to obtain the data needed to make a more accurate estimate of the flow direction. Any modifications to the current well network indicated by flow direction will be addressed by later changes to this plan.

\subsection{Scope and Organization}

This document describes the facilities and associated outlying equipment, operational history and characteristics of the stored waste at WMA A-AX. This is followed by discussions of the site geology and hydrogeology used in design and operating the monitoring well network and in interpreting the groundwater data. The historic groundwater chemistry is also provided. Next is the WMA A-AX conceptual model used to guide work on identification of potential sources and source type, migration pathways, and driving forces.

The plan includes a description of current well locations and construction, sample constituents, and sampling frequency. It also discusses the adequacy of the current monitoring network required for compliance with 40 CFR 265, Subpart F and WAC 173-303-400 (3). Finally, this document provides the basis for rapid development of an assessment plan should any of the indicator parameters result in a validated exceedence of calculated background critical means. 


\subsection{Background Information}

To design and operate an adequate groundwater monitoring program for a Waste Management Area (WMA), knowledge of the surface conditions, facility histories, the nature of possible contamination, and subsurface conditions is required. This section provides an overview of the facilities that comprise WMA A-AX. It includes a brief account of the facilities' operational histories, a description of waste currently stored in the tanks, and a discussion of the subsurface conditions found under the 241-A and 241-AX Tank Farms. The stratigraphic framework is provided along with the nature of the unconfined aquifer and the current state of groundwater quality in the immediate area of the WMA. The bulk of the information in this section can be found in Agnew (1997), Anderson (1990), Hanlon (1999), Caggiano (1991), U.S. Department of Energy-RL (DOE/RL)-88-21 (1996), and Kupfer et al. (1997).

\subsection{Facility Description}

Located along the eastern boundary in the southeast quadrant of the 200 East Area, both 241-A and 241-AX Tank Farms are near numerous double-shell tank (DST) farms with an extensive system of transfer pipes/valves, pumps, and catch tanks (Figure 1.2). Included in the farm perimeters are seven inactive diversion boxes listed as part of the WMA A-AX (DOE/RL-88-21 1996) and the 244-AR Vault, located west of the 241-A Tank Farm.

The 241-A Tank Farm contains six 100 series single-shell tanks (SSTs) constructed from 1954 to 1955. The 241-AX Tank Farm contains four 100 series SSTs constructed from 1963 to 1964 . These tanks have an operating capacity of $1 \mathrm{Mgal}(3,785,400 \mathrm{~L})$ each. The SSTs in these farms were used to store mixed wastes primarily from the Plutonium-Uranium Extraction (PUREX) process.

Tank configuration and dimensions are shown in Figure 2.1. The tanks are below grade with at least six feet of soil cover to provide radiation shielding to protect operating personnel. The inlet and overflow lines are located near the top of the liners. The 241-AX Tank Farm is the only one in the 200 East Area to have a system of underground leak detection pipes located horizontally under the tanks. Access to these laterals is through vertical $12 \mathrm{ft}(3.7 \mathrm{~m})$ diameter caissons sunk approximately $70 \mathrm{ft}(21.3 \mathrm{~m})$ below grade (Figure 2.1). From each caisson, three laterals are bored horizontally under each tank bottom about ten feet below the cement base pad. Currently none of these laterals are in use (Hanlon 1999).

The SSTs were constructed in place with carbon steel (American Society for Testing and Materials [ASTM] A283 Grade C in 241-A Tank Farm and ASTM A201 Grade C in 241-AX Tank Farm) lining the bottom and sides of a reinforced concrete shell. The tanks in the 241-AX Tank Farm, although essentially the same as 241-A Tank Farm, have a grid of drain slots beneath the steel liner bottom to collect potential tank leakage. Any leaked liquid is then diverted to a leak detection well. The grids also served as an escape route for free water released from concrete grout during initial heating of the tank. 


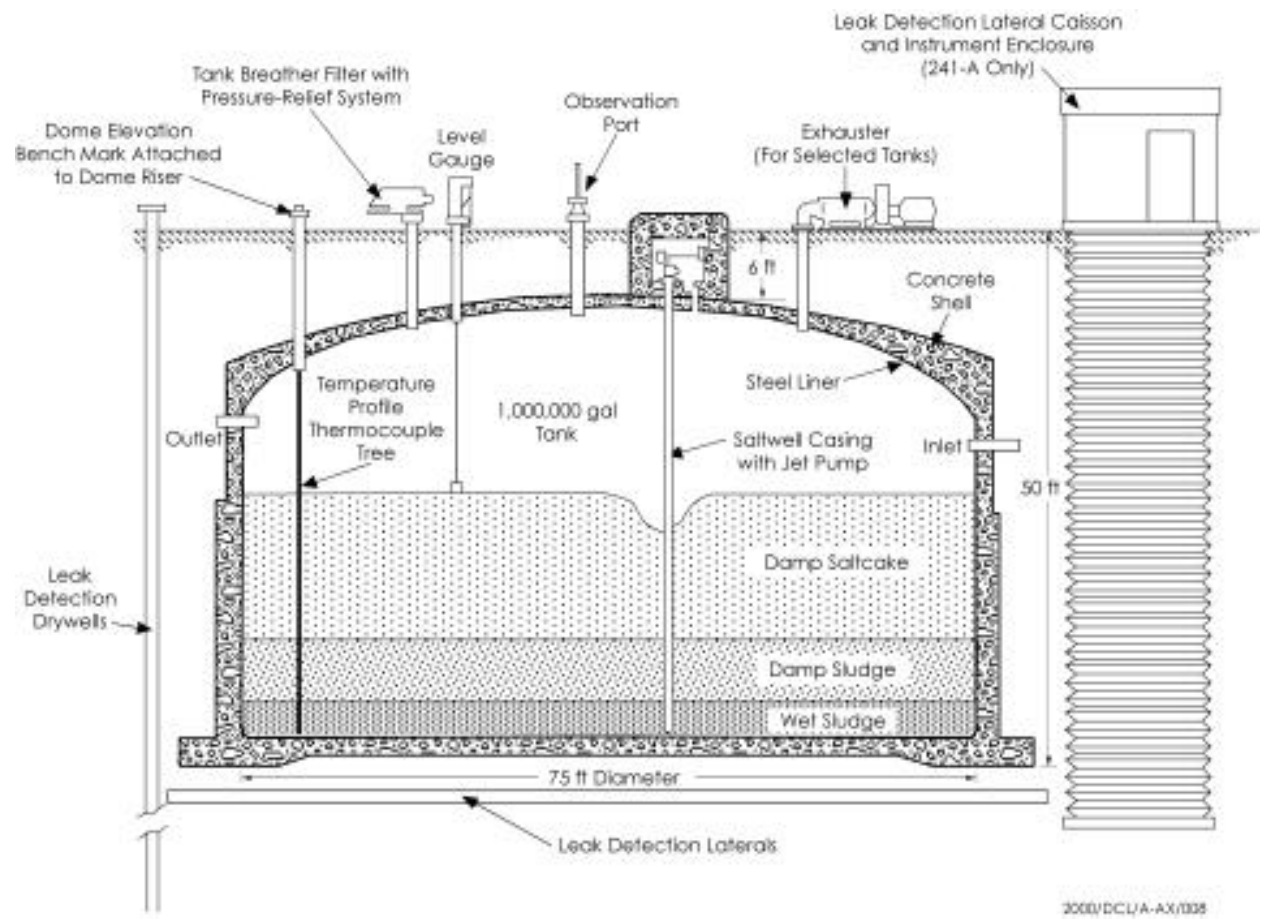

Figure 2.1. Schematic Showing the Construction of a Typical Single-Shell Tank with a $1 \mathrm{Mgal}$ Capacity. After DOE/RL-88-21.

The 241-A and 241-AX Tank Farms, along with 241-SX Tank Farm, contain the only tanks with a right angle intersection of the sides and the bottom. Most of the other SST tanks have a dished intersection between sides and bottom. The configuration of the side-bottom intersections and the method of welding combine to create an inherent weakness at these locations when subjected to heat stresses. In some cases, these weaknesses have resulted in leaks to the subsurface.

Some waste generates enough heat to cause boiling of the tank supernatate. The tanks in both 241-A and 241-AX Tank Farms were self-boiling. Vapors from the boiling action were routed through headers to condensers, which are vented to the atmosphere through filters. In the past the resulting condensate was either discarded to cribs or returned to the waste tank where it was used to maintain the desired liquid levels in tanks.

Recently added to the WMA, the 244-AR Vault contains four permitted underground tanks along with overhead crane operations equipment. Constructed in 1976, the four underground units are stainless steel waste storage tanks. Also included are high-pressure pumps used to transfer water or tank supernate through specially designed nozzles to tanks being sluiced. A schematic showing tank configurations, depth below grade and the overhead crane is provided in Figure 2.2.

Nonboiling liquid waste from the operations building was sent to the tank farms via underground lines and diversion boxes. Leaks occurred in the diversion boxes or into the surrounding line encasement drain and was collected by catch tanks. 


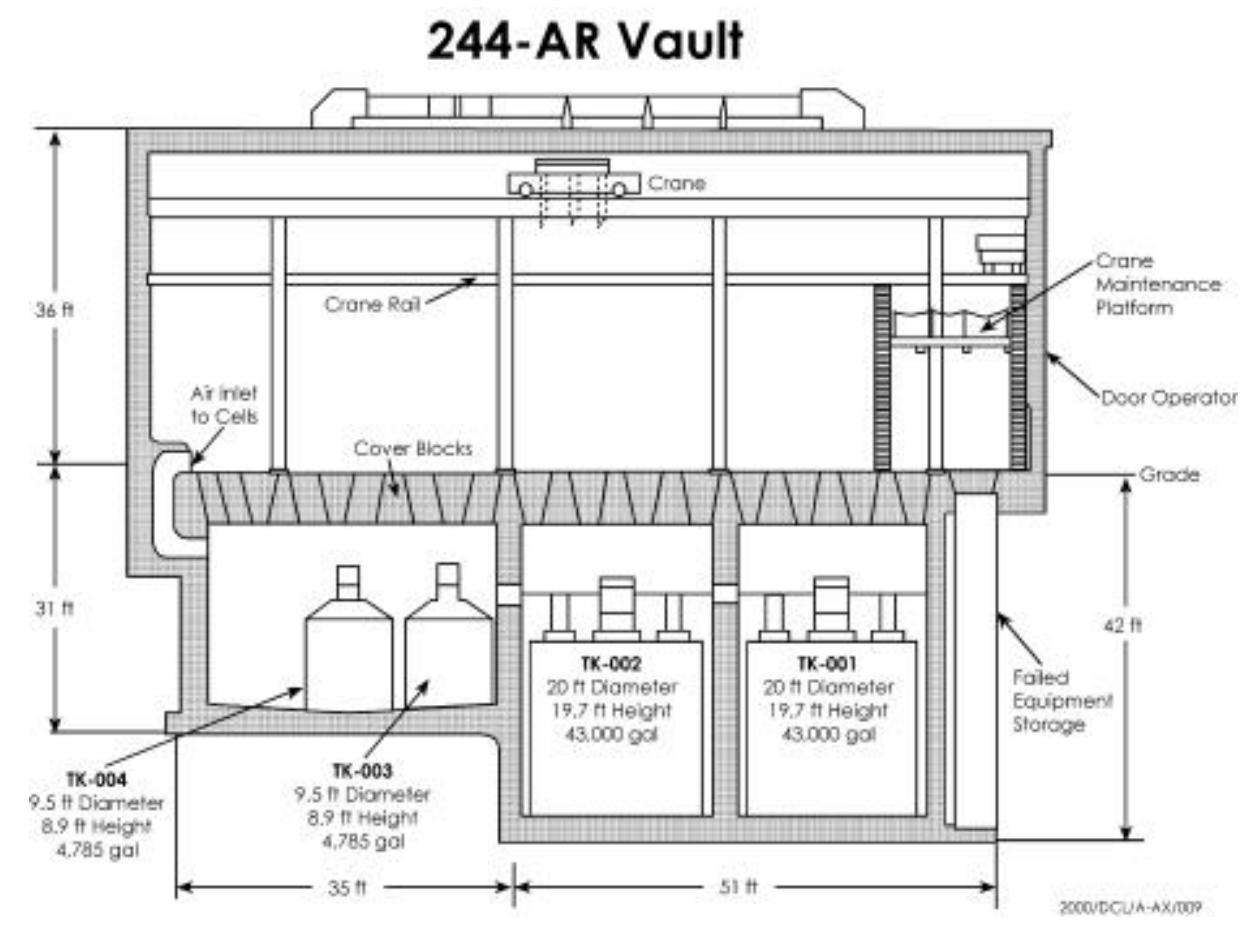

Figure 2.2. Schematic of the 244-AR Vault, which Consists of Four Smaller Tanks with Dimensions and Storage Capacities as Shown. This vault was used in the transfer of waste from B-Plant to the eastern farms and in sluicing operations during the 1970s. It has recently been included in the Part A Hazardous Waste Permit Application (DOE 1996). After DOE/RL-88-21.

The leaked liquids were then pumped to the large SSTs. These transfer lines and diversion boxes are listed as part of the WMA in the Part A permit (DOE/RL-88-21 1996). The catch tanks, however, are not listed as being part of the managed Resource Conservation and Recovery Act (RCRA) WMA.

Included in the SST system are seven inactive diversion boxes designated as waste piles along with the transfer pipes to the DST systems and associated equipment (DOE/RL-88-21 1996) (Figure 2.3). All diversion boxes used within the farms are inactive and presently isolated or covered from the weather. As used here, "isolated" means exterior water intrusion has been restricted. The diversion boxes are included in the RCRA permit application because they were an integral part of the waste transfer system. The boxes are important in the plan because some were the sites of contaminant releases to the subsurface. It is estimated that each box contains $50 \mathrm{lbs}(23 \mathrm{kgm})$ of lead, and they are listed as waste piles (Hanlon 1999).

Pertinent information on the A-AX tanks, waste transfer vault, and the diversion boxes is provided in three tables. Table 2.1 lists the tanks, vault, and diversion box numbers, year of construction, year removed from service, and operating capacity. The date a tank was declared a leaker, the volume of leaked waste and associated curies is provided in Table 2.2. Table 2.3 provides the current inventory and status of the 100 series tanks in WMA A-AX. Data on tank integrity, the total waste in the tank, total 


\section{Typical Transfer System}

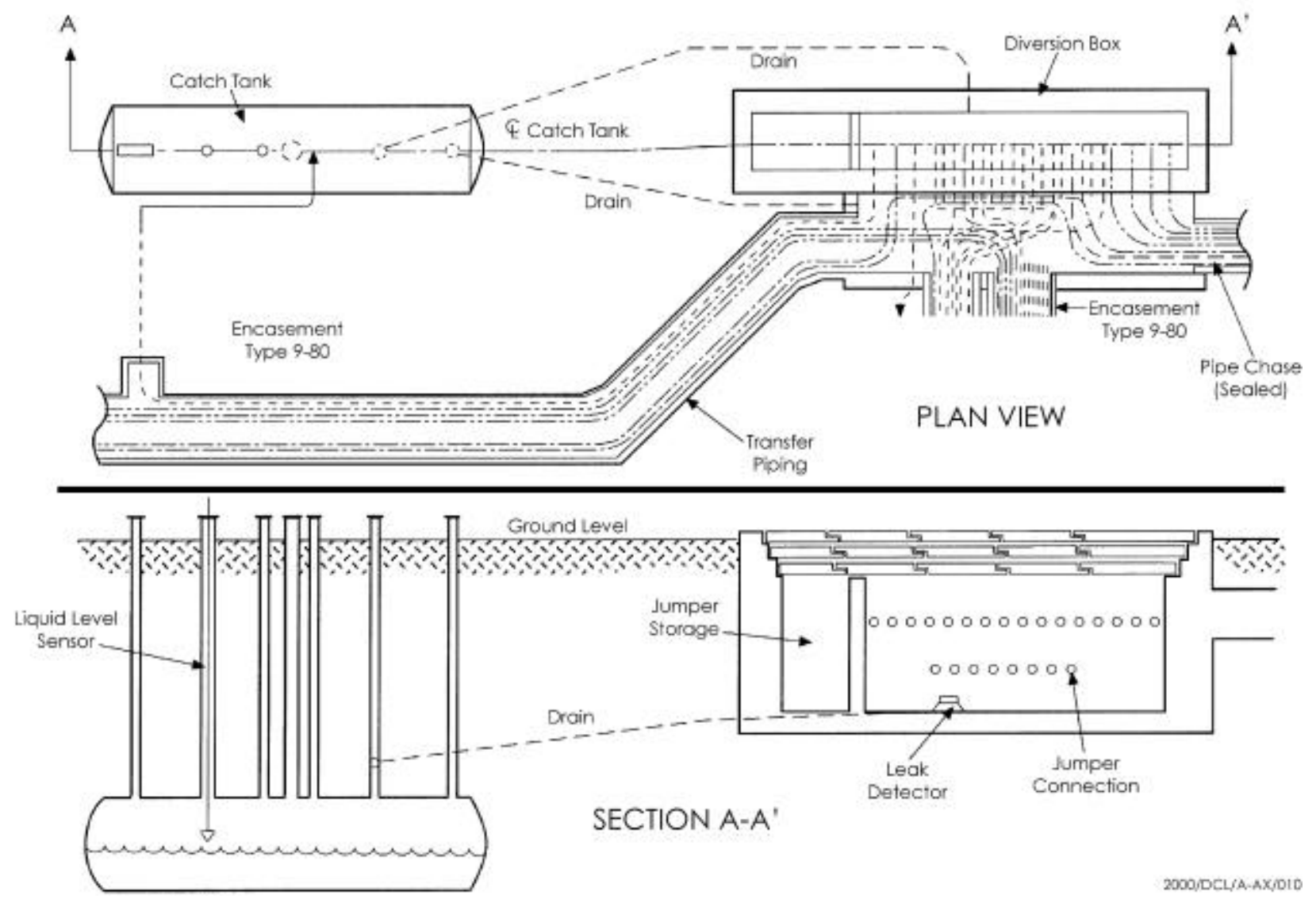

Figure 2.3. Schematic of a Typical Diversion Box Transfer System. There are seven diversion boxes listed in the Part A Hazardous Waste Permit Application (1998). After DOE/RL-88-21.

pumpable liquid remaining in the tanks, total liquid pumped out of the tank during interim stabilization and the sludge/salt cake volumes for each tank are included in this table (Hanlon 1999).

After November 1980, high-level liquid radioactive waste was sent only to DST farms where the tanks have two separate liners of carbon steel with a leak detection system between the two. The first DSTs were placed into service in 1971. The 241-AN Tank Farm, containing seven DSTs constructed in the early 1980s, and 241-AZ Tank Farm, containing two DSTs constructed during the mid-1970s, are north of 241-AX Tank Farm. The 241-AY Tank Farm, east of 241-AX Tank Farm, contains two DSTs constructed during the late 1960s. Directly south of 241-A Tank Farm is the 241-AW Tank Farm, with six DSTs constructed during the late 1970s, and the 241-AP Tank Farm, with eight DSTs constructed during the mid-1980s. Each of these farms has associa ted underground transfer lines, catch tanks, and diversion boxes, which not only limit the location of monitoring wells with respect to WMA A-AX but also present potential complications for discerning contaminant sources both in the past and future. 
Table 2.1. Summary Data for Facilities Comprising WMA A-AX

\begin{tabular}{||l|c|c|c||}
\hline \multicolumn{1}{|c|}{ Tank Number } & $\begin{array}{c}\text { Year of } \\
\text { Construction }\end{array}$ & $\begin{array}{c}\text { Year Removed } \\
\text { from Service }\end{array}$ & $\begin{array}{c}\text { Operating Capacity } \\
\text { (gal) }\end{array}$ \\
\hline \hline $241-A-101$ & $1954-1955$ & 1980 & $1,000,000$ \\
\hline $241-A-102$ & $1954-1955$ & 1980 & $1,000,000$ \\
\hline $241-A-103$ & $1954-1955$ & 1980 & $1,000,000$ \\
\hline $241-A-104$ & $1954-1955$ & 1975 & $1,000,000$ \\
\hline $241-A-105$ & $1954-1955$ & 1963 & $1,000,000$ \\
\hline $241-A-106$ & $1954-1955$ & 1980 & $1,000,000$ \\
\hline $241-A X-101$ & $1963-1964$ & 1980 & $1,000,000$ \\
\hline $241-A X-102$ & $1963-1964$ & 1980 & $1,000,000$ \\
\hline $241-A X-103$ & $1963-1964$ & 1980 & $1,000,000$ \\
\hline $241-A X-104$ & $1963-1964$ & 1978 & $1,000,000$ \\
\hline \hline & $\begin{array}{c}\text { Year of } \\
\text { Diversion Box }\end{array}$ & $\begin{array}{c}\text { Year Removed } \\
\text { from Service }\end{array}$ & Operating Capacity \\
(lbs)
\end{tabular}

Table 2.2. Tank Leak Volume Estimates (After Hanlon 1999)

\begin{tabular}{||l|c|c|c|c|c||}
\hline Tank Number & $\begin{array}{c}\text { Date Declared } \\
\text { Confirmed or } \\
\text { Assumed Leaker }\end{array}$ & Volume Leaked (gal) & $\begin{array}{c}\text { Associated } \\
\text { Kilocuries } \\
\mathbf{1 3 7} \mathbf{C s}\end{array}$ & $\begin{array}{c}\text { Interim } \\
\text { Stabilized } \\
\text { Date }\end{array}$ & $\begin{array}{c}\text { Leak } \\
\text { Estimate } \\
\text { Updated }\end{array}$ \\
\hline \hline $241-\mathrm{A}-103$ & 1987 & 5,500 & & $06 / 88$ & 1987 \\
\hline $241-\mathrm{A}-104$ & 1975 & 500 to 2,500 & 0.8 to 1.8 & $09 / 78$ & 1983 \\
\hline 241-A-105 & 1963 & 10,000 to 277,000 & 85 to 760 & $07 / 79$ & 1991 \\
\hline 241-AX-102 & 1988 & 3,000 & & $09 / 88$ & 1989 \\
\hline 241-AX-104 & 1977 & 8,000 & & $08 / 81$ & 1989 \\
\hline
\end{tabular}


Table 2.3. Inventory and Status by Tank (After Hanlon 1999)

\begin{tabular}{||l|l|c|c|c|c|c|c|c||}
\hline \hline Tank & $\begin{array}{l}\text { Tank } \\
\text { Integrity }\end{array}$ & $\begin{array}{c}\text { Stabilization/ } \\
\text { Isolation } \\
\text { Status }\end{array}$ & $\begin{array}{c}\text { Total } \\
\text { Waste } \\
\text { (Kgal) }\end{array}$ & $\begin{array}{c}\text { Total } \\
\text { Pumped } \\
\text { (Kgal) }\end{array}$ & $\begin{array}{c}\text { Drainable } \\
\text { Liquid } \\
\text { Remain } \\
\text { (Kgal) }\end{array}$ & $\begin{array}{c}\text { Pumpable } \\
\text { Liquid } \\
\text { Remain } \\
\text { (Kgal) }\end{array}$ & $\begin{array}{c}\text { Sludge } \\
\text { (Kgal) }\end{array}$ & $\begin{array}{c}\text { Salt } \\
\text { Cake } \\
\text { (Kgal) }\end{array}$ \\
\hline \hline A-101 & Sound & PI & 953 & 0.0 & 721 & 697 & 3 & 442 \\
\hline A-102 & Sound & IS/PI & 41 & 39.5 & 6 & 0 & 15 & 22 \\
\hline A-103 & $\begin{array}{l}\text { Assumed } \\
\text { leaker }\end{array}$ & IS/IP & 371 & 111.0 & 20 & 0 & 366 & 0 \\
\hline A-104 & $\begin{array}{l}\text { Assumed } \\
\text { leaker }\end{array}$ & IS/IP & 28 & 0.0 & 0 & 0 & 28 & 0 \\
\hline A-105 & $\begin{array}{l}\text { Assumed } \\
\text { leaker }\end{array}$ & IS/IP & 19 & 0.0 & 4 & 0 & 19 & 0 \\
\hline A-106 & Sound & IS/IP & 126 & 0.0 & 7 & 0 & 126 & 0 \\
\hline AX-101 & Sound & PI & 748 & 0.0 & 558 & 534 & 3 & 359 \\
\hline AX-102 & $\begin{array}{l}\text { Assumed } \\
\text { leaker }\end{array}$ & IS/IP & 39 & 13.0 & 17 & 3 & 7 & 28 \\
\hline AX-103 & Sound & IS/IP & 112 & 0.0 & 36 & 3 & 2 & 110 \\
\hline AX-104 & $\begin{array}{l}\text { Assumed } \\
\text { leaker }\end{array}$ & IS/IP & 7 & 0.0 & 0 & 0 & 7 & 0 \\
\hline $\begin{array}{l}\text { IP = Intrusion prevention. } \\
\text { IS = Interim stabilized or isolated. } \\
\text { PI = Partially interim. }\end{array}$ & & & & & & & & \\
\hline
\end{tabular}

Located just south of SST 241-AX 103, adjacent to the WMA boundary and just north of the 241-AW DST Farm is the 242-A Evaporator/Crystallizer. The 242-A Evaporator Building contains the evaporator vessel, supporting process equipment, and the principal process components of the evaporator-crystallizer system (DOE/RL-92-04 1993). This is currently an active facility periodically running waste concentration campaigns with active waste transfers. A leak associated with this facility would be difficult to separate from a WMA leak.

\subsection{Facility Operational History}

The Hanford Site, established in 1943, was originally designed, built, and operated to produce weapons-grade plutonium using production nuclear reactors and chemical processing plants. In March 1943, construction began on three reactor facilities (B, D, and F Reactors) and three chemical process facilities (B, T, and U plants). After WWII, six more reactors were built, the last being N Reactor (DOE/RL-92-04 1993).

Operations in the 200 Areas were centered on the separation of special nuclear materials from irradiated nuclear fuel. There are two main separation processing facilities located in the 200 East Area. The first is B Plant (221-B Building), which began operations in 1945, where plutonium and later certain fission products were separated from uranium. The other is the PUREX Plant (202-A Building), con- 
structed between 1953 and 1955, where plutonium and uranium were extracted from reactor fuels (Kupfer et al. 1997; DOE/RL-92-04 1993). The waste sent to tanks in WMA A-AX came primarily from operations at the PUREX Plant and the B Plant waste fractionation process.

Between 1945 and 1952, the bismuth phosphate process (BPP) was used at B Plant to recover plutonium. The process was discontinued there in 1952. In 1968, B Plant was used for a second mission, recovering cesium and strontium fission products from the liquid wastes stored in the SSTs and from wastes concurrently produced by the PUREX process. This process was termed B Plant Waste Fractioni zation. Stored PUREX and Reduction-Oxidation (REDOX) waste tank supernates were processed for ${ }^{137} \mathrm{Cs}$ and ${ }^{90} \mathrm{Sr}$ removal. In addition, the waste produced at PUREX during this time was processed for ${ }^{90} \mathrm{Sr}$ removal. Settled sludge solids in the 241-A and 241-AX SSTs were also sluiced and transferred to B Plant for ${ }^{90} \mathrm{Sr}$ removal. In 1974, work began on precipitating and encapsulating the recovered cesium and strontium. Cesium recovery operations in B Plant were completed in September 1983, while strontium recovery operations were completed in February 1985. Other than the capsule storage at the Waste Encapsulation and Storage Facility, the B Plant facility is inactive (DOE/RL-92-05 1993; Westinghouse Hanford Company [WHC]-MR-0132 1990; Kupfer et al. 1997).

Between waste fractionization campaigns, a solvent extraction process was used in B Plant to recover, concentrate and purify ${ }^{90} \mathrm{Sr}$ and rare earths from the acid waste being generated at PUREX. The PUREX high level waste produced before 1968 but present in the settled sludges in 241-A and 241-AX Tank Farm SSTs were also processed with this solvent extraction process (Kupfer et al. 1997). Various organics including tributyl phosphate (TBP) were used as extractants and as chelating agents. These organics were part of the solvent extraction system wastes and were the main source of the organics currently found in the Hanford waste tanks.

Used between 1956 and 1972, the PUREX process was an advanced solvent extraction technique adapting TBP in normal paraffin hydrocarbon for recovery of plutonium, uranium and neptunium from nitric acid solutions of irradiated uranium. This process was utilized at the PUREX plant between 1956 and 1972, processing aluminum-clad fuels and after 1966, some Zircaloy-clad fuels (Kupfer et al. 1997). After 11 years in standby, the plant resumed operations in November 1983. Only Zircaloy-clad fuels were processed from 1983 to 1989. In 1966 and 1970, two thorium campaigns were run in the 202-A Building. The waste generated from these events was sent to the 241-C Tank Farm. Operations ceased at PUREX Plant in 1990, and a decision to shut down the facility was announced in December 1992.

\subsubsection{Tank Operational History}

The PUREX Plant came on line as a production facility in January 1956 and processed approximately $72 \%$ of the reactor fuel produced at the DOE Hanford Site. This included natural and enriched aluminum clad uranium fuel, aluminum-clad thorium fuel, and Zircaloy-clad N Reactor fuel. The processing wastes included high-level solvent extraction wastes, both self-boiling and "non-boiling," and the cladding wastes, organic wash wastes and cell drainage. The neutralized PUREX acid waste was routed to the 241-A, the 241-AX Tanks Farms, and later to DSTs. Until 1969, the sodium carbonate organic wash wastes were combined with the self-boiling high level PUREX wastes for purposes of waste reduction. After 1969, these wastes were routed to non-boiling low level waste storage in 241-C Tank Farm. 
The first two tanks to receive PUREX waste were 241-A-101 and 241-A-102. These tanks were partially filled with wastes that did not boil because the initial volumes were large. In May 1956, waste that was high in salts was sent to 241-A-103 where the volume was controlled sufficiently so that the wastes generated enough heat to boil. The remaining tanks in this farm came on line in the next few years receiving PUREX wastes, either high level and/or organic wash waste. Agnew (1997) states that, although tanks in both 241-A and 241-AX Tank Farms were equipped for boiling wastes, only 241-A-101, -102, -103, -104, and -105 were self-concentrating tanks.

The 241-A Tank Farm received primarily PUREX waste from the 202-A Building until 1968. After B Plant Waste fractionization began, these tanks were sluiced beginning with 241-A-101 to provide feed for the fractionation process. Tanks 241-A-104 and 241-A-105 were found to be leaking. Sluicing operations were completed in 241-A-104 to remove residual waste. The history for 241-A-105 is more complicated and is provided in the next section.

The 241-AX Tank Farm began receiving waste primarily from the PUREX plant in 1965. Tanks in this farm continued to receive PUREX waste until 1969. Tanks 241-AX 101 and -102 began receiving fractionization waste in 1969. These tanks were sluiced in 1975 to provide feed for B Plant. Tanks 241-AX-103 and -104 received only PUREX waste until 1973 when PUREX sludge tank supernate was stored in these tanks. Each tank was sluiced in 1976. The liquid level in 241-AX-104 was kept low after sluicing because of questionable tank integrity.

Except for 241-A-104, -105 and 241-AX-104, after 1977, the tanks in both farms received waste listed as evaporator feed, double-shell slurry feed (DSSF), non-complexed waste (NCPLX), complexed waste (CPLX), complex concentrated waste (CCW), complexant concentrate (CC), and Hanford Defense Residual Liquid (HDRL) (WHC-MR-0132). Presumably, this organic waste is from the final solvent extraction process run at B-Plant to concentrate ${ }^{90} \mathrm{Sr}$ and rare earths.

The tanks in both farms were removed from service in 1980 except for three tanks (Hanlon 1999). The dates of last service for tanks 241-A-104, -A-105, and -AX-104 were 1975, 1963, and 1978, respectively. Information on the nature of waste received at each tank along with estimates of waste volume that boiled off and the amounts of cooling water added is provided in Anderson (1990). Specific tank waste additions and transfers through 1979, the last full year of active operation, are included. After this time, information on SST operations can be found in the "living document," HNF-EP-0182-131 (Hanlon 1999), which is published monthly to report on tank status and farm operations. Appendix A contains the current total waste inventory of hazardous and nuclear chemistry on a tank-by-tank basis. Inventories were estimated with the Hanford defined waste model (Agnew 1997). These data are used to form a complete list of site-specific contaminants for groundwater water monitoring and for comparison with observed groundwater chemistry.

In general, vaults were utilized as a central receiving station between SSTs or from other waste generating facilities to the SSTs. Vaults could also be used to treat waste already stored in the SSTs. The 244-AR Vault was constructed with stainless steel interim waste storage tanks so that acid waste from PUREX could be stored and processed for ${ }^{90} \mathrm{Sr}$ removal without having to neutralize or reacidify the 
wastes. In addition, high-pressure pumps in the 244-AR-Vault were also used to transfer water or tank supernate through specially designed nozzles to tanks being sluiced for sludge removal to support the fractionization process at B Plant during the 1970s.

\subsubsection{Tank Leak History}

It is difficult to determine the exact causes of tank failure. While there are several mechanisms suggested for failure, incliding stress, corrosion, cracking and mechanical tearing of the liner, the extreme difficulty of direct inspection makes it impossible to accurately characterize specific failures. After testing in 1958 at the SX Tank Farm, a horizontal system of three laterals was installed in 1961 beneath the 241-A tanks to detect radiation and monitor temperature changes under the tanks. At this time, additional dry wells were also installed. A later improvement in leak detection was the incorporation of drain channels and sump collection wells in the AX tank design.

Tanks storing self-boiling wastes have been equipped with liquid level measurement devices that provide an indication of changes in tank contents. These farms also include dry wells but additional wells were drilled in strategic locations around various non-boiling waste tanks as a means of detecting tank leakages. The dates of these drywell installations at 241-A- and 241-AX Tank Farms can be found in Anderson (1990).

The 241-A Tank Farm has three tanks that have leaked, 241- A-103, A-104, and A-105, while the 241-AX Farm has two, 241-AX-102 and AX-104. Agnew (1998) advised that the leaks in AX-102 and AX-104 were located in the header lines at the 20-inch vapor line in each tank. Tank 241-A-105 has experienced the largest leak, and its leak history is discussed in detail below. The estimated total leak volume from each of these tanks is provided in Table 2.3.

Tanks 241-A-103, 241-A-104, and 241-AX-102 have leak volumes below 5500 gal (Hanlon 1999). Leak volumes for 241-A-103 (5,500 gal) and 241-AX-102 (3000 gal) were estimated based solely on observed liquid level decreases, which is thought to be the most accurate method of leak volume estimation. The approximate leak volume for 241-A-104 is between 500 and 2,500 gal. All of these tanks are listed in Hanlon (1999) as interim stabilized.

The actual leak volume for 241-AX-104 is not known. Tank 241-AX-104 began receiving PUREX waste in 1958 and was sluiced in 1969. It was not discovered as a leaker until it was sluiced again in 1975. The remaining liquid was removed and the tank was taken out of service. Tank 241-AX-104 is one of 19 SSTs, listed as leakers, with no direct means of estimating leak volumes. Since no estimate of liquid levels can be obtained directly, a method to estimate leakage was devised based on the cumulative leak volume of 18 tanks for which there are liquid level data. It was assumed that the cumulative leakage of the 18 tanks with known leak volumes should equal that of the 19 tanks for which there was no way of estimating leak volume. This method results in a leak estimate for 241-AX-104 of 8,000 gal (Hanlon 1999).

Not included in tank leak estimates are surface leaks, waste transfer line leaks, leaks at the joint for the overflow or fill lines, cooling/raw waterline leaks, or surface intrusions from rain infiltration. Leaks 
from catch tanks, diversion boxes, or encasements are also not included in volume estimates (Hanlon 1999). For events that are known and documented, the location and identifying number of surface spills, overflows, or line leaks are provided on the location map in Figure 1.2.

The following description of past events at tank 241-A-105 are taken from WHC-MR-0264 (1991) and Allen (1991). Although built in 1955, 241-A-105 was not used until May 1962 when it was made ready to support the PUREX cesium recovery program. Before that time, the tank contained a maximum of 18 in. (46 cm) of water. In May 1962, 330,000 gal of supernate were added followed by several transfers of waste into and out of the tank. PUREX waste was added and the tank reached boiling temperature in early March 1963. As early as September 1963, unexplained tank level increases (12 in.) started to occur. Steam was probably forming under the tank liner at this time, deforming it upward (WHC-MR-0264 1991). In November 1963, low-intensity radiation was detected in one leak-detection lateral. Later evidence indicated, however, that the suspected side wall leak had self-healed. The tank was filled to capacity in December 1964.

In January 1965, a severe steam explosion occurred in tank 241-A-105. Shortly after, an 80,000-gal $(302,833 \mathrm{~L})$ bulge in the floor of the metal liner was discovered. The bulge is approximately $8 \mathrm{ft}(2.4 \mathrm{~m})$ above the concrete foundation. Subsequently, radiation was detected in drywells around the tank and it was declared a leaker. In 1968, when the tank was pumped down for sluicing, it was established that the metal liner had ruptured and significant amounts of sludge were suspected to reside under the bulge.

Sluicing operations to remove waste from the tank began in August 1968 and continued intermittently through August 1970. To keep tank temperatures below operating limits, cooling water was added until January 1979 when the tank was put on a portable exhauster system.

The current estimate of the total leak volume for tank $241-\mathrm{A}-105$ is 10,000 to 277,000 gal $(37,900$ to 1,050,000 L) (WHC-MR-0264; Hanlon 1999). Earlier estimates excluded the cooling water leaks, but in 1991, the leak volume estimates for this tank were updated in accordance with the Washington State Administrative Code (WAC) regulations Dangerous Waste Regulations (WAC 173-303-070 [2][a][ii], as amended, Washington State Department of Ecology (Ecology), 1990, Olympia, Washington). Consequently any cooling water added and subsequently leaked from the tank must be classified as a waste and included in the total leak volume.

For the initial leak prior to 1968 , the total leak volume is estimated as 5,000 to 15,000 gal $(18,927$ to 56,781 L). While the tank was being sluiced from August 1968 to November 1970, it was estimated that 5,000 to 30,000 gal $(18,927$ and 113,562 L) leaked from the tank. From November 1970 to December $1978,610,000$ gal $(2,309,101 \mathrm{~L})$ of cooling water were added to the tank. In WHC-EP-0410 (Allen 1991), it is estimated that 378,000 to 410,000 gal $(1,430,886$ to $1,552,019 \mathrm{~L})$ of water evaporated out of the 241-A-105 tank from November 1970 to December 1978. Subtracting the minimum evaporation estimate from the added cooling water provides a maximum estimate of 232,000 gal $(878,216 \mathrm{~L})$ of cooling water leakage during those 8 years. Estimated leak volumes are reported for the remaining tanks in both farms in Table 2.2. 


\subsubsection{Recent History}

Currently, treatment of the mixed waste in the SST system, consisting of all SST farms, occurs when solids and interstitial liquids are separated and/or cooling liquids are added. These treatment processes involve, but are not limited to, mechanical retrieval, sluicing, and saltwell pumping of the mixed waste. The entire SST system has a process design limit of 600,000 gal $(2,271,240 \mathrm{~L})$ per day based on the simultaneous pumping of two SSTs in a 24-hour period. Ancillary equipment use for the transfer of liquid mixed waste consists of: 1) centrifugal pumps capable of pumping liquid mixed waste at 400 gal $(1,514 \mathrm{~L})$ per minute, 2$)$ induction pumps capable of pumping liquid waste from the salt well at 5 gal (19 L) per minute, and 3) associated valves and piping to the DST system.

Another activity conducted in SST farms is leak detection. The primary method of ascertaining the integrity of the tanks is by monitoring the liquid levels within the tanks, accounting for liquid evaporation and accounting for known liquid increases. The liquid level method has the ability to detect a leak of 8,000 gal (30,283 L) in a nonboiling tank (moist solid), with a leak detection limit on liquid surfaces of $\sim 1,300$ gal $(\sim 4,900 \mathrm{~L})$. Up until 1994, a secondary method of leak detection around the SSTs included the use of gross gamma logs from adjacent dry wells located in the farms. Recent data were compared to previous logs to determine if contamination exists and ascertain if contamination movement has occurred. Unfortunately, this method is limited to detection of only the gamma emitting waste in proximity of the borehole and excludes detection of the mobile beta emitting radionuclides like ${ }^{99} \mathrm{Tc}$.

Because of the advanced age of the SSTs, the pumpable liquid is currently being removed from the SSTs and stored in DSTs as part of the interim stabilization project. For a review of stabilization pumping at WMA A-AX, see Table 2.3. Most of the pumpable liquid has been removed from these tanks with the exception of 241-A-101 (697,000 gal [2,638,432 L]) and 241-AX-101 (534,000 gal $[2,021,410 \mathrm{~L}])$. Saltwell pumping of these tanks is scheduled sometime before FY 2004, the date for final stabilization of all SSTs.

The 242-A Evaporator-Crystallizer lies on the southern boundary of WMA A-AX next to well 299-E25-46. It started operations in March 1977 but was shut down in April 1989 because of regulatory issues pending subsequent upgrading. The evaporator was restarted in April 1994 and is currently operating although the last campaign shown in Hanlon (1999) was in 1997. The facility operates under

a vacuum, using evaporative concentrations with subsequent crystallization and precipitation of salt crystals. If effluent leaked from this facility or associated waste transfer lines has entered the groundwater, such contamination could be confused with tank farm sources.

\subsection{Waste Characteristics}

The combination of the PUREX campaigns and the B Plant fractionation processes have produced the most complicated combination of wastes at the DOE Hanford Site (Agnew 1997). Agnew identified twenty-one distinct waste types derived from the PUREX campaign between 1956 and 1988. These wastes take one of three general forms: sludge, salt cake, or liquid. Different salts precipitated over time as water evaporated from the waste producing the salt cake found in the tanks today. The sludge consists 
of partial solids such as hydrous metal oxides that precipitated from the neutralized high level acid wastes. Liquids exist as tank supernates or as interstitial liquid leaving a stratified structure of salt, sludge, and liquid within the tanks.

To assure that the groundwater monitoring approach at WMA A-AX provides a complete constituent list for sample analysis, especially in the event the site is placed in assessment, it is necessary to study these waste types and identify key elements in the wastes. The following discussion provides information on the chemical and radioactive species derived from the PUREX and B Plant fractionation processes cataloged for each tank in Appendix A.

The most current tank-by-tank waste inventory can be found in the best-basis inventory developed as part of the Standard Inventory task and maintained by the River Protection Project (Kupfer et al. 1997). This inventory includes not only estimates based on models of the chemical processes used for plutonium-uranium extraction but also the analytical data of waste samples taken directly from specific tanks. Direct tank sampling and analysis is an ongoing project, and the database is currently being compiled. This waste characterization information is used in Section 4.0 to determine the main constituent list for chemical analyses for groundwater monitoring at WMA A-AX.

Waste chemistry related to the primary processes conducted at PUREX and routed to tanks in the 241-A and 241-AX Tank Farms are discussed. The pertinent processes are listed:

- PUREX primary process

- Organic wash wastes

- PUREX to B Plant ${ }^{137}$ Cs recovery (B Plant fractionation)

- PUREX to B Plant ${ }^{90} \mathrm{Sr}$ recovery (B Plant fractionation process).

Information on the chemical species in the waste streams sent to tanks in WMA A-AX are taken from Agnew (1997), Anderson (1990), and analytical results of wastes samples from specific tanks in 241-A and 241-AX Tank Farms. Although Hanlon (1999) reports the general chemistry of the last waste received by the SSTs, it is necessary to consider all the waste types stored in the tanks since residual vadose zone plumes from past tank associated leaks can act as sources for groundwater contamination (Johnson and Chou 1998; Narbutovskih 1998).

The bulk of the waste directed to the 241-A Tank Farm was neutralized PUREX acid waste (P). The principal constituents in the waste are sodium, nitrate, sulfate, phosphate, aluminum, and iron. The principal radioactive nuclides in WMA A-AX tank waste, in order of decreasing concentrations, are principally ${ }^{90} \mathrm{Sr},{ }^{137} \mathrm{Cs},{ }^{99} \mathrm{Tc}$, and ${ }^{60} \mathrm{Co}$. Although ${ }^{239,240} \mathrm{Pu}$ and its daughter ${ }^{241} \mathrm{Am}$ are detectable, it is unlikely that either is sufficiently soluble to be found in the groundwater. There appears to be very little

${ }^{129} \mathrm{I}$ in the tank wastes. Iodine tends to be volatile during generation in the reactor and, like tritium, 
migrates to the outer regions of the fuel rod. The ${ }^{129}$ I would have been removed along with the tritium in the cladding wastes, which were disposed to cribs. Alternatively, the ${ }^{129}$ I may have escaped the liquid wastes as $\mathrm{I}_{2}$ gas, and therefore not represent a significant part of the disposed liquids.

The organic solvent used in PUREX was treated with potassium permanganate and sodium carbonate followed by dilute nitric acid. The resulting organic wash waste (OWW) was eventually combined and sent to the self-boiling tanks until 1969. The main constituents in OWW were sodium, lead, nitrate, potassium, and manganese.

The waste streams added last to the tanks during the ${ }^{137} \mathrm{Cs}$ and ${ }^{90} \mathrm{Sr}$ fractionation processes caused the total tank waste to be extremely complicated chemically. The Phosphotungstic Acid Process (PTA), one method used for the recovery of ${ }^{137} \mathrm{Cs}$, left minor amounts of tungsten and phosphate in the wastes. Zeolites were used as resins in another ${ }^{137} \mathrm{Cs}$ recovery process. For the final ${ }^{90} \mathrm{Sr}$ extraction process, several water-soluble organics were used as chelating agents to remove divalent metals such as iron from solution. These organics were ethylenediamine tetra acetic acid (EDTA) and N (2-hydroxyethyl) ethylenediamine tetra acetate (HEDTA) or citrate. Di (2-ethylhexyl) phosphoric acid (D2EHPA) and TBP was used as extractants. Approximately $20 \%$ of the ${ }^{90} \mathrm{Sr}$ was left in the waste and returned to the tanks. These organics are the complexents added to the tanks in 1978 and 1979.

Based on analyses of waste samples, other important constituents are the metals $\mathrm{Na}, \mathrm{Ca}, \mathrm{Al}, \mathrm{Ba}, \mathrm{K}, \mathrm{U}$, $\mathrm{Fe}, \mathrm{Si}, \mathrm{Pb}, \mathrm{Ni}$, and Mn. Although Agnew (1997) has estimated significant chromium concentrations for most of the tanks in both 241-A and 241-AX Tank Farms, only samples from tank A-106 confirm these estimates. Samples of both solids/sludges and liquids indicate that there may not be much chromium in the tank waste. Also, a source of chromium was not identified in descriptions of separation processes or wastes streams. Although two thorium campaigns were conducted at PUREX in 1966 and 1970, the wastes from these events were sent to 241-C Tank Farm. The site-specific parameters found in Section 4.4 are based on the chemical species identified in the above discussion.

\subsection{Geology}

This section describes the geology beneath WMA A-AX. It contains a revision of the geologic description given in Caggiano and Goodwin (1991). It is important that a detailed understanding of the local subsurface be obtained prior to design or revision of a groundwater monitoring network. Such information allows optimization of the well locations and well construction. Knowledge of the subsurface is also required to evaluate flow properties, interpret the groundwater chemistry and evaluate the efficiency of the network over time. The results of this geologic and stratigraphic revision were used to construct the conceptual model for WMA A-AX presented in the next section.

The geologic descriptions are based on recent interpretations of the stratigraphy in the 200 East Area, data from the installation of a new well, and interpretations of gross gamma-ray logs and moisture data that were not included in Caggiano and Goodwin (1991). Archived soil samples were reevaluated to assist interpretations of areas left ambiguous after inspecting the geology and drillers logs. Results were compared to regional studies to assure coherence within the larger framework of stratigraphic interpretations. 
The last section contains information pertaining to physical properties of the unconfined aquifer. Aquifer properties were determined from the stratigraphic interpretations, aquifer tests, and from the regional groundwater table provided in the most recent annual groundwater monitoring report (Hartman et al. 2000).

\subsubsection{General Stratigraphy}

The regional geologic setting of the Pasco Basin and the Hanford Site has been described by Delaney et al. (1991) and DOE (1988). Tallman et al. (1979) and more recently Lindsey et al. (1992) described the geology of the 200 East Area. The geology specific to WMA A-AX was first described by Price and Fecht (1976a, 1976b) and then by Caggiano and Goodwin (1991). Most recently, the WMA A-AX geology was summarized in Narbutovskih et al. (1996), Jones et al. (1998), and Williams et al. (2000). This update is based on those previous works amended to include use of gross gamma-ray logs, neutron moisture data, re-evaluated borehole samples, and laboratory moisture, and particle size distribution data.

In summary, the geology of the 200 East Area consists of the Elephant Mountain Member of the Saddle Mountains Basalt, Columbia River Basalt Group overlain by the Ringold Formation, and the Hanford Formation. The Ringold Formation consists of fluvial and lacustrine sediments deposited by the ancestral Columbia and Clearwater-Salmon river systems between 3.4 and 8.5 Ma. Lindsey (1996) described the Ringold Formation in terms of three informal members: 1) the member of Wooded Island, 2) the member of Taylor Flat, and 3) the member of Savage Island. Of these, only the member of Wooded Island is present beneath the 200 East Area.

The member of Wooded Island consists of five separate units dominated by fluvial gravels. The gravels are designated (from bottom to top) as Units A, B/D, C, and E and are separated by fine-grained deposits typical of overbank and lacustrine environments. The lowermost of the fine-grained sequences is designated the Lower Mud Unit. Only gravel Units A and E are present beneath the 200 East Area, and the Ringold Formation is entirely absent beneath the northern part of the 200 East Area (Lindsey 1992).

The Ringold Formation gravels are clast- and matrix-supported, pebble to cobble conglomerates with a fine to coarse sand matrix (Lindsey 1996). The most common clast lithologies are basalt, quartzite and intermediate to felsic volcanics. Interbedded lenses of silt and sand are common. Cemented zones within the conglomerates are discontinuous and of variable thickness. In outcrop, the conglomerates are massive, plane-bedded, or cross-bedded.

The Hanford formation overlies the Ringold Formation and consists of glaciofluvial sediments deposited by cataclysmic floods from Glacial Lake Missoula, Pluvial Lake Bonneville, and ice-margin lakes. These sediments resulted from at least four major glacial events and were deposited between about $1 \mathrm{Ma}$ and $13 \mathrm{Ka}$ ago. The formation consists of pebble to boulder sized gravel, fine- to coarse-grained sand, and silt- to clayey-silt. These deposits are divided into three facies: 1) graveldominated facies, 2) sanddominated facies, and 3) silt-dominated facies. These same facies are referred to as coarse-grained deposits, plane-laminated sand facies, and rhythmite facies, respectively in Bjornstad et al. (1987). The Hanford formation is present throughout the Hanford Site and is up to $213 \mathrm{ft}(65 \mathrm{~m})$ thick (Delaney et al. 1991). 
1. GraverDominated Facies. This facies generally consists of pebble to boulder gravel, coarse-grained basaltic sand, and coarse-grained, etc. These deposits display an open framework texture, massive bedding, plane to low-angle bedding, and large-scale planar cross bedding of the cobbles in outcrop. Sand and silt beds are interbedded throughout the facies. Gravel clasts are dominantly basalt with lesser amounts of Ringold Formation clasts such as granite, quartzite, and gneiss (Lindsey 1992). The gravel dominated facies was deposited by high-energy floodwaters in or immediately adjacent to the main cataclysmic flood channels.

2. Sand-Dominated Facies. This facies consists of fine- to coarse-grained sand and pebble gravel. The sands typically have a high basalt content and are commonly referred to as black, gray, or salt-andpepper sands (Lindsey 1992). They may contain small pebbles and rip-up clasts, pebble-gravel interbeds, and silty interbeds less than $3 \mathrm{ft}(1 \mathrm{~m})$ thick. The silt content of the sands is variable, but where it is low, a well-sorted and open framework texture is common. This facies commonly displays plane lamination and bedding. It less commonly has channelfill sequences (Lindsey 1992). The sand dominated facies was deposited adjacent to main flood channels during the waning stages of flooding. The facies is transitional between the gravel-dominated facies and the silt-dominated facies.

3. Silt-Dominated Facies. This facies consists of thin bedded, plane-laminated and ripple cross-laminated silt and fine- to coarse-grained sand. Beds are typically a few inches to several tens of inches thick and commonly display normally graded-bedding (Lindsey 1992). Local clay-rich beds occur in the siltdominated facies (Myers and Price 1979; Bjornstad et al. 1987; DOE 1988). Sediments of this facies were deposited under slack water conditions and in back-flooded areas (DOE 1988).

\section{Methodology}

The interpretations of subsurface geology in this chapter are based, in part, on the work of previous studies (see above) and, in part, on reexamination and reevaluation of geologic and gross gamma ray log data obtained during installation of boreholes at WMA A-AX. Figure 2.4 shows the locations of boreholes in the vicinity of WMA A-AX that were used in this study. The quality of data obtained from the boreholes varies and is a function of when the boreholes were drilled, drilling methods, and purposes of the boreholes. Table 2.4 summarizes pertinent information about the boreholes used for this study.

The boreholes were chosen for one of three reasons: 1) they are recently constructed RCRA wells and therefore have more complete and accurate subsurface information then many older wells, 2) they have relatively detailed driller's logs and associated information such as gamma ray logs, and 3) they have information of a lesser quality but are in critical locations. Most, but not all, of the boreholes used by Caggiano and Goodwin (1991) are include in Table 2.4.

Geologic interpretations were made by comparing the well-site geologist's logs to selected, archived samples at the Hanford Geotechnical Sample Library. The geological interpretations were then modified and refined if necessary based on the archived samples. This was particularly important where only incomplete driller's logs existed. Gross gamma ray logs and laboratory moisture data were then compared with the lithologic logs. In some cases, the use of gross gamma-ray logs allowed refinement of the data by permitting more accurate placement of geologic contacts. 


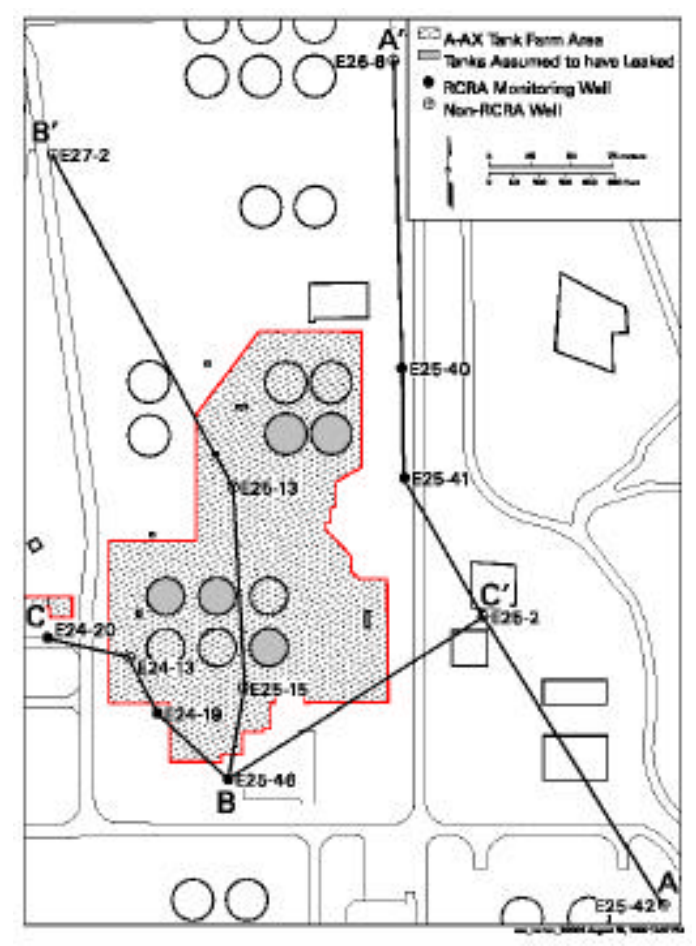

Figure 2.4. Map Showing the Locations of Wells and Cross Sections

\subsubsection{Site-Specific Stratigraphy}

The vadose zone beneath WMA A-AX is between $266 \mathrm{ft}(81 \mathrm{~m})$ and $295 \mathrm{ft}(90 \mathrm{~m})$ thick (Hartman 1999) and lies mostly within the Hanford formation. The water table elevation is about $400 \mathrm{ft}(122 \mathrm{~m})$ and currently lies in conglomerates most likely belonging to the Ringold Formation. The unconfined aquifer beneath WMA A-AX is estimated to be about $89 \mathrm{ft}(27 \mathrm{~m})$ thick.

Plates 1 through 3 show cross-sections adjacent to and through WMA A-AX. Cross-section locations are shown in Figure 2.4. Cross-section A-A' illustrates the geology east of the WMA. Crosssection B-B' illustrates the geology through the WMA in a north-south direction. Cross-section C-C' shows geologic relationships across the WMA in an east-west direction.

Six lithologic units are recognized in the WMA A-AX area.

- Surficial deposits and backfill

- Hanford formation - upper gravel sequence

- Hanford formation - sand sequence

- Hanford formation - lower gravel sequence

- Ringold Formation - Unit A

- Columbia River Basalt Group. 
Table 2.4. Sources of Data for Geologic Descriptions

\begin{tabular}{|c|c|c|c|c|c|}
\hline Borehole & $\begin{array}{c}\text { Elevation } \\
\text { (meters above } \\
\text { sea level) })^{(\mathbf{a})} \\
\end{array}$ & $\begin{array}{l}\text { Drill } \\
\text { Date }\end{array}$ & $\begin{array}{c}\text { Drill } \\
\text { Depth } \\
(\mathbf{m} \text { bgs })^{(\mathbf{a}, \mathbf{b})} \\
\end{array}$ & Sample Method & $\begin{array}{c}\text { Sources of Information } \\
\text { Used in This Report }\end{array}$ \\
\hline 299-E24-13 & 210.5 & 1969 & 103.6 & Hard tool & $\begin{array}{l}\text { As-built diagram } \\
\text { Driller's log } \\
\text { Re-log of selected } \\
\text { existing samples } \\
\end{array}$ \\
\hline 299-E-24-19 & 210.6 & 1989 & 92.4 & $\begin{array}{l}\text { Drive barrel }(0 \text { to } 87 \mathrm{~m}) \text {, } \\
\text { Hard tool }(87 \text { to } 93 \mathrm{~m})\end{array}$ & $\begin{array}{l}\text { Well completion report } \\
\text { Geologist's log } \\
\text { Gross gamma-ray } \log ^{(c)} \\
\text { Lab moisture data }\end{array}$ \\
\hline 299-E24-20 & 209 & 1991 & 92.6 & $\begin{array}{l}\text { Drive barrel ( }(0 \text { to } 98 \mathrm{~m}) \\
\text { Hard tool }(89 \text { to } 92.6 \mathrm{~m})\end{array}$ & $\begin{array}{l}\text { Well construction report } \\
\text { Geologist's log } \\
\text { Gross gamma-ray } \log ^{(c)} \\
\text { Lab moisture data }\end{array}$ \\
\hline 299-E25-02 & 205.3 & 1954 & 114.3 & Hard tool & $\begin{array}{l}\text { As built diagram } \\
\text { Driller's log } \\
\text { Re-log of selected } \\
\text { existing samples } \\
\text { Gross gamma-ray } \log ^{(d)}\end{array}$ \\
\hline 299-E25-13 & 207.9 & 1963 & 96.6 & $\begin{array}{l}\text { Drive barrel }(0 \text { to } 22.8 \mathrm{~m} \text {; } \\
24.4 \text { to } 79.2 \mathrm{~m}) \\
\text { Hard tool }(22.8 \text { to } 24.4 \mathrm{~m} \text {; } \\
79.2 \text { to } 96.6 \mathrm{~m})\end{array}$ & $\begin{array}{l}\text { As-built diagram } \\
\text { Driller's log } \\
\text { Re-log of selected } \\
\text { existing samples } \\
\end{array}$ \\
\hline 299-E25-15 & 210.1 & 1969 & 103.6 & $\begin{array}{l}\text { Hard tool }(0 \text { to } 28.9 \mathrm{~m} \text {; } \\
38.7 \text { to } 103.6 \mathrm{~m}) \\
\text { Drive barrel }(28.9 \text { to } \\
38.7 \mathrm{~m})\end{array}$ & $\begin{array}{l}\text { As-built diagram } \\
\text { Driller's log }\end{array}$ \\
\hline 299-E25-40 & 202 & 1989 & 83.5 & Drive barrel & $\begin{array}{l}\text { Well completion report } \\
\text { Geologist's log } \\
\text { Re-log of some existing } \\
\text { samples } \\
\text { Gross gamma-ray } \log ^{(\mathrm{c})} \\
\text { Lab moisture data }\end{array}$ \\
\hline 299-E25-41 & 203.6 & 1989 & 85 & $\begin{array}{l}\text { Drive barrel }(0 \text { to } 68.6 \mathrm{~m}) \\
\text { Hard tool }(68.6 \text { to } 85 \mathrm{~m})\end{array}$ & $\begin{array}{l}\text { Well completion report } \\
\text { Geologist's log } \\
\text { Re-log of some existing } \\
\text { samples } \\
\text { Gross gamma-ray log }{ }^{(c)} \\
\text { Lab moisture data }\end{array}$ \\
\hline
\end{tabular}


Table 2.4. (contd)

\begin{tabular}{|c|c|c|c|c|c|}
\hline Borehole & $\begin{array}{c}\text { Elevation } \\
\text { (meters above }^{(\text {mea level })^{(a)}} \\
\text { sea }\end{array}$ & $\begin{array}{l}\text { Drill } \\
\text { Date }\end{array}$ & $\begin{array}{c}\text { Drill } \\
\text { Depth } \\
(\mathbf{m} \text { bgs })^{(\mathbf{a}, \mathbf{b})}\end{array}$ & Sample Method & $\begin{array}{c}\text { Sources of Information } \\
\text { Used in This Report }\end{array}$ \\
\hline 299-E25-42 & 207 & 1991 & 89.8 & $\begin{array}{l}\text { Drive barrel }(0 \text { to } 82.3 \mathrm{~m}) \\
\text { Hard tool }(82.3 \text { to } 89.8 \mathrm{~m})\end{array}$ & $\begin{array}{l}\text { As-built diagram } \\
\text { Geologist's log } \\
\text { Gross gamma-ray } \log ^{(c)} \\
\text { Lab moisture data }\end{array}$ \\
\hline 299-E25-46 & 210.8 & 1992 & 94.6 & Drive barrel & $\begin{array}{l}\text { Well construction report } \\
\text { Survey data report } \\
\text { Geologist's log } \\
\text { Gross gamma-ray } \log ^{(c)} \\
\text { Lab moisture data }\end{array}$ \\
\hline 299-E26-06 & $\begin{array}{l}196.5 \text { (relative } \\
\text { to top of } \\
\text { casing) }\end{array}$ & 1960 & $\begin{array}{l}88.4 \text { (below } \\
\text { top of } \\
\text { casing) }\end{array}$ & Hard tool & $\begin{array}{l}\text { As-built diagram } \\
\text { Driller's log } \\
\text { Re-log of some existing } \\
\text { samples }\end{array}$ \\
\hline 299-E27-02 & 203.1 & 1948 & 95.1 & Hard tool & $\begin{array}{l}\text { As-built diagram } \\
\text { Driller's log }\end{array}$ \\
\hline $\begin{array}{l}\text { (a) Relative } \\
\text { (b) Bgs = b } \\
\text { (c) Log obt } \\
\text { (d) Log obt }\end{array}$ & $\begin{array}{l}\text { brass cap unless } \\
v \text { ground surface } \\
\text { d during well co } \\
\text { d after installatic }\end{array}$ & herwise & loted. & & \\
\hline
\end{tabular}

The Elephant Mountain Member of the Saddle Mountains Basalt, Columbia River Basalt Group is the basement rock beneath the WMA. The Elephant Mountain Member is medium to fine-grained tholeiitic basalt with abundant microphenocrysts of plagioclase (DOE 1988). The Elephant Mountain Member has been dated by the K/Ar method at $10.5 \mathrm{Ma}$ (McKee et al. 1977) and consists of two flows beneath the 200 East Area. In the WMA A-AX area the Elephant Mountain Member was penetrated only in one borehole (well 299-E25-2) where it is $375 \mathrm{ft}(94.5 \mathrm{~m}$ ) below ground surface (bgs).

Overlying the Columbia River Basalt are the Ringold Formation Unit A gravels. These gravels are equivalent to the Ringold Unit A of Lindsey (1992) and Jones et al. (1998), to the middle Ringold of Price and Fecht (1976a, 1976b), and to Pliocene-Miocene continental conglomerates of Reidel and Fecht (1994). Caggiano and Goodwin (1991) state that Tallman et al. (1979) place the boundary of the middle Ringold and the Hanford formation within this sequence. But it is not clear whether this sequence is part of the middle Ringold. Although this report interprets the sequence of sediment overlying the basalt as Ringold Unit A gravels, it is possible that the gravels have been reworked either by the Columbia River during pre-Pleistocene time or by Pleistocene cataclysmic floods. Evidence for reworked Ringold gravels is found in the east and southeast portions of the 200 East Area. The Ringold Formation has been completely removed from the northern portion of the 200 East Area by subsequent Pleistocene flooding. Whether this gravel sequence is Ringold or Hanford sediment has important implications for the permeability and flow rate of groundwater in the unconfined aquifer. Overall, Hanford formation gravels 
are significantly (10 to 100 times) more permeable than gravel sequences in the Ringold Formation. The differences are attributed mainly to the higher degree of matrix cementation and induration common in the Ringold sediments (Wurstner et al. 1995).

The Ringold Formation Unit A is described on borehole logs of cuttings and samples as gravel, sandy gravel, and slightly sandy gravel to muddy sandy gravel. The gravels are generally poorly sorted, subangular to rounded, poorly sorted, and consist of pebbles and cobbles in a sand and silt matrix. They range in composition from about $80 \%$ basaltic to as little as $20 \%$ basaltic. The Ringold Formation Unit A is generally non-calcareous in the area but does contain minor cementation in a few boreholes. Cementation occurs as 1 to $3 \mathrm{~mm}$ size aggregates of sand grains. The bottom of the Ringold Unit A was penetrated only in well 299-E25-2 where it is $109 \mathrm{ft}(33 \mathrm{~m})$ thick.

Based on observations of outcrop and intact core, the Ringold Formation Unit A fluvial gravels consist of clast- and matrix-supported, pebble to cobble conglomerate with a fine to coarse sand matrix and interbedded fine to coarse sand and silt lenses (Lindsey 1996). Cementing ranges from absent to well developed. Cemented Ringold Formation conglomerates are discontinuous zones of variable thickness. The conglomerates exhibit massive, planer, and cross-bedding. Clast imbrication is also common (Lindsey 1996).

Intercalated in the Ringold Unit A conglomerates are laterally discontinuous, fine- to coarse-grained, cross-bedded sands. Also interbedded in the conglomerates are thin, variably colored silty deposits, typically with disrupted bedding (Lindsey 1996). The Ringold Formation Unit A is interpreted to represent fluvial gravels and sands that were rapidly deposited from bed-load in shallow channels across a gravelly floodplain.

A fine-grained sequence overlies the Ringold Formation Unit A gravels in all but one borehole in the WMA A-AX area and, although the sequence is thin, it is one of the most prominent units in the area. The fine-grained sequence is described on borehole logs of cuttings and samples from the WMA A-AX area as silt to sandy silt with lesser amounts of slightly gravelly sandy silt. Some gross gamma-ray logs show a distinct increase in activity in the upper portion of the sequence. Available moisture data (Plates 1, 2, and 3) show the Ringold fine-grained sequence has higher moisture content than the adjacent sediments. No perched water was noted on top of the sequence (Caggiano and Goodwin 1991), but the water table was higher in the past. Thus, the current high moisture content may be a remnant of a higher water table. The fine-grained sequence ranges from about 4 to $15 \mathrm{ft}(1.2$ to $4.6 \mathrm{~m})$ in thickness beneath WMA A-AX (Table 2.5). It is thickest northwest of the 241-AX Tank Farm and thins to the southeast where it is absent at borehole 299-E25-42. It is present further south at borehole 299-E25-48 at the 241-AP Tank Farm. Further northwest, it is absent in most boreholes at 241-C Tank Farm.

The fine-grained sequence has been considered to be the Ringold Formation Lower Mud Unit by some past workers (Lindsey et al. 1992; Lindsey and Reynolds 1998). This report considers the finegrained unit to be one of the interbedded fluvial and overbank sands and silts found locally in the middle part of the Ringold Unit A (Lindsey 1992). This interpretation is consistent with the removal of the Ringold Formation Unit E and Lower Mud Unit by Pleistocene floods. The Ringold Unit E and Lower Mud Unit are absent throughout the northern part and much of the central part of the 200 East Area. 
Table 2.5. Data Used to Construct Cross Sections and Structure Contour Maps

\begin{tabular}{|c|c|c|c|c|c|c|c|c|c|c|c|}
\hline Borehole & $\begin{array}{c}\text { Surface } \\
\text { Elevation } \\
\text { (ft) }\end{array}$ & $\begin{array}{c}\text { Total } \\
\text { Depth } \\
\text { (ft) }\end{array}$ & $\begin{array}{c}\text { Thickness } \\
\text { of the } \\
\text { Hanford } \\
\text { Formation } \\
\text { Upper } \\
\text { Gravel } \\
\text { Sequence } \\
\text { (ft) }\end{array}$ & $\begin{array}{c}\text { Elevation } \\
\text { of Top } \\
\text { of the } \\
\text { Hanford } \\
\text { Sand } \\
\text { Sequence } \\
\text { (ft) }\end{array}$ & $\begin{array}{c}\text { Thickness } \\
\text { of Hanford } \\
\text { Formation } \\
\text { Sand } \\
\text { Sequence } \\
\text { (ft) }\end{array}$ & 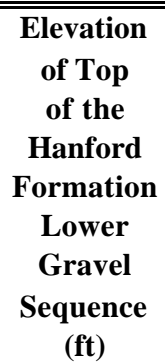 & $\begin{array}{c}\text { Thickness } \\
\text { of the } \\
\text { Hanford } \\
\text { Formation } \\
\text { Lower } \\
\text { Gravel } \\
\text { Sequence } \\
\text { (ft) }\end{array}$ & $\begin{array}{l}\text { Elevation of } \\
\text { the Top of } \\
\text { the Ringold } \\
\text { Formation } \\
\text { (ft) }\end{array}$ & $\begin{array}{l}\text { Thickness } \\
\text { of the } \\
\text { Ringold } \\
\text { Formation } \\
\text { (ft) }\end{array}$ & $\begin{array}{c}\text { Thickness } \\
\text { of the } \\
\text { Ringold } \\
\text { Formation } \\
\text { Fine } \\
\text { Grained } \\
\text { Sequence } \\
\text { (ft) }\end{array}$ & $\begin{array}{c}\text { Elevation } \\
\text { of the } \\
\text { Top of } \\
\text { Basalt } \\
\text { (ft) }\end{array}$ \\
\hline 299-E24-13 & 690.8 & 340 & 120 & 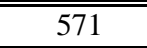 & 150 & NP & & 421 & TD & 17 & \\
\hline 299-E24-19 & 690.84 & 303 & 125 & 566 & 152 & NP & & 414 & TD & 8 & \\
\hline 299-E24-20 & 685.85 & 304 & 100 & 586 & 175 & $\mathrm{NP}$ & & 411 & TD & 5 & \\
\hline 299-E25-2 & 673.5 & 375 & 122 & 552 & 83 & 469 & 50 & 419 & 109 & 13 & 310 \\
\hline 299-E25-13 & 682.12 & 317 & 75 & 607 & 180 & NP & & 427 & TD & 20 & \\
\hline 299-E25-15 & 689.3 & 340 & & & & & & 414 & TD & 5 & \\
\hline 299-E25-40 & 663 & 274 & 100 & 563 & 95 & 468 & 60 & 408 & TD & 2 & \\
\hline 299-E25-41 & 668 & 279 & 100 & 568 & 93 & 475 & 60 & 415 & TD & 14 & \\
\hline 299-E25-42 & 679 & 295 & 80 & 599 & 140 & 459 & TD & & & & \\
\hline 299-E25-46 & 691.79 & 310 & 70 & 622 & 203 & $\mathrm{NP}$ & & 419 & TD & 5 & \\
\hline 299-E26-6 & 645 & 290 & NP & 645 & 180 & 465 & 63 & 402 & TD & 4 & \\
\hline 299-E27-2 & 666.3 & 312 & 20 & 646 & 255 & NP & & 411 & TD & 15 & \\
\hline
\end{tabular}


Alternatively, the fine-grained sequence may represent post-Ringold and pre-Hanford formation fluvial sediments from the Columbia River system or may be part of the transitional sand and silt dominated facies of the Hanford formation.

A structure contour map on the top of the Ringold Formation is shown in Figure 2.5. The figure shows a gentle dome with about $25 \mathrm{ft}$ (7.6-m) of relief centered between 214-A and 241-AX Tank Farms. Data used to construct this and the following structure contour maps are provided in Table 2.5.

The Hanford formation lower gravel sequence overlies the Ringold Formation Unit A. This sequence is equivalent to the lower gravel sequence of the Hanford formation of Lindsey et al. (1992), to the Hanford formation H3 sequence of Lindsey et al. (1994), and to the outburst flood deposits (Qfg) of Reidel and Fecht (1994).

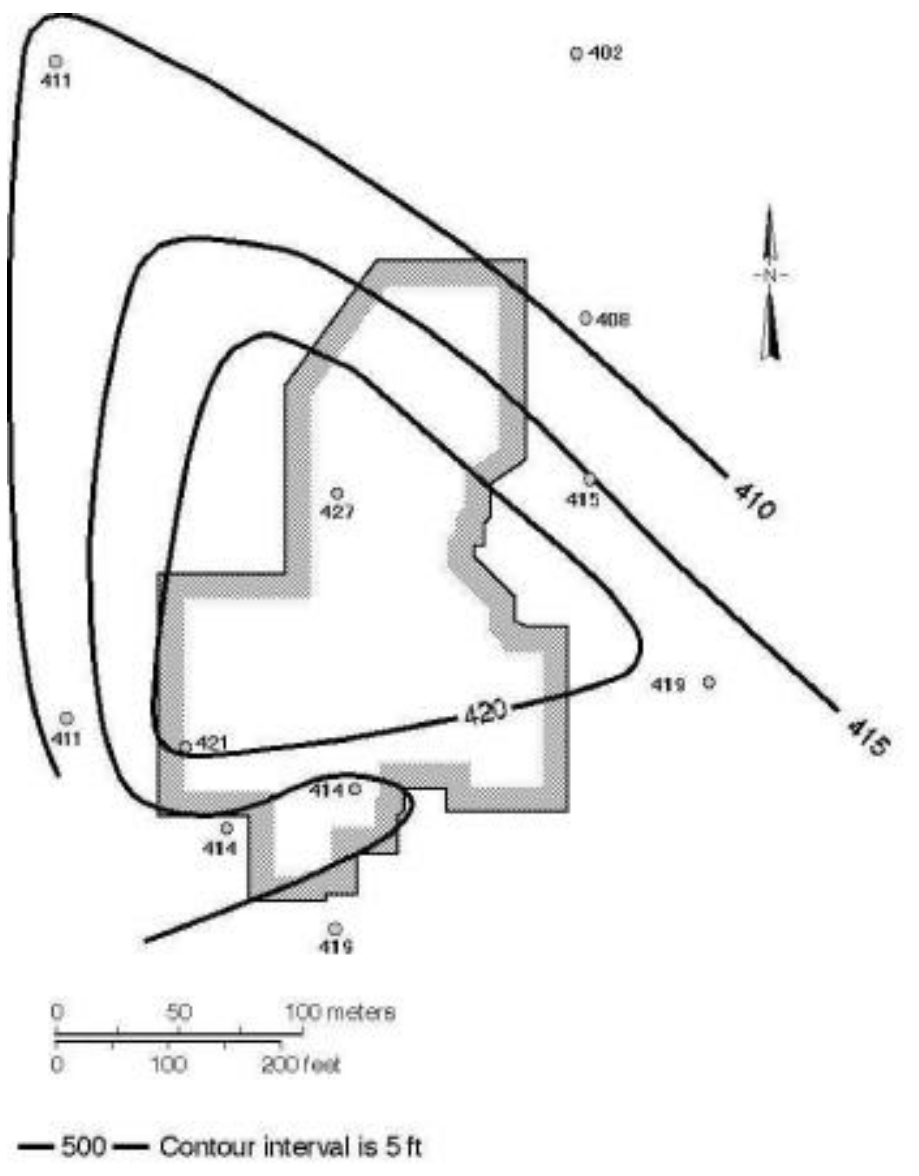

Figure 2.5. Structure Contour Map of the Top of the Ringold Formation (shaded outline denotes A-AX Tank Farm boundaries) 
The Hanford formation lower gravel sequence is described on borehole logs of cuttings and samples from the WMA A-AX area as a gravelly sand with some gravel and sandy gravel. The gravels are poorly sorted, subrounded to subangular and have basalt contents up to about $80 \%$. Individual beds are from about 5 to $45 \mathrm{ft}$ ( 1.5 to $14 \mathrm{~m}$ ) thick and appear to form gradational contacts with overlying and underlying beds. Silt beds and calcareous zones are not as common in the lower gravel sequence as they are in the overlying sediments.

Based on observations of outcrop and intact core, the lower gravel sequence is interpreted to be the high-energy, graveldominated facies of the Hanford formation. This facies is typically open framework or matrix supported framework, pebble to boulder gravel with massive bedding, plane to low-angle bedding, and cross-bedding. Lenticular and discontinuous units of sand-dominated facies are interbedded with gravel-dominated facies. The Hanford formation gravel sequence was deposited by high-energy, cataclysmic, Pleistocene floods.

The Hanford lower gravel sequence is present only in boreholes 299-E25-2, -40, -41, and -42 in the extreme eastern part of the area. The top is chosen as the bottom of the lowermost sand or slightly gravelly sand that is at least $70 \mathrm{ft}(21 \mathrm{~m})$ thick. In some boreholes, the top of the gravel sequence coincides with a subtle decrease in activity on the gross gamma-ray logs at the contact with the overlying Hanford sand sequence.

The Hanford formation sand sequence overlies the lower gravel sequence. This sequence is equivalent to the sandy sequence of the Hanford formation of Lindsey (1992), to the Hanford formation H2 sequence of Lindsey et al. (1994), and to the outburst flood deposits of silts and sand described by Reidel and Fecht (1994). The Hanford formation sand sequence is described on borehole logs of cuttings from the WMA A-AX area as silty sand, sand, and slightly gravelly sand. Individual beds $30 \mathrm{ft}(\geq 9 \mathrm{~m})$ thick are common and grade into overlying and underlying beds within the sand sequence. The sandy beds are commonly referred to as "salt and pepper" sands and range from $30 \%$ basaltic and $70 \%$ felsic to $70 \%$ basaltic and $30 \%$ felsic in composition. Calcium carbonate occurs in the Hanford sand sequence as poorly developed cemented zones and nodules. The amount of calcium carbonate is small and usually less than 1 wt. \%.

Silt lenses and thinly interbedded zones of silt and sand, which are calcareous in places, are common but are not abundant in the Hanford sand sequence. These finer grained zones cannot be correlated among boreholes and, with some exceptions, are not reflected in the gross gamma ray logs or moisture data. This is probably because moisture samples are normally collected every $5 \mathrm{ft}(1.5 \mathrm{~m})$ during drilling, and this interval is too large to sample most thin zones. The fine structure observed in some older gross gamma-ray logs may reflect changes in the silt content that were not detected during drilling.

The Hanford formation sand sequence consists of sand-dominated facies intercala ted with beds of the silt-dominated and gravel-dominated facies. The Hanford sand sequence is present in all boreholes at the WMA A-AX. Except in borehole 299-E24-20, the top of the Hanford sand sequence is picked at the bottom of the lowest sandy gravel or gravelly sand that overlies a minimum of 20 to $25 \mathrm{ft}$ (6 to $8 \mathrm{~m}$ ) of sand or slightly gravelly sand (see cross-sections in Plates 1 through 3). In borehole 299-E24-20, the top 
of the sand sequence was chosen at a small but distinct change in the gross gamma-ray log that correlated with a similar change in the gross gamma-ray log at the top of the sand sequence in adjacent borehole 299-E24-19.

A structure contour map of the top of the Hanford sand sequence is shown in Figure 2.6. The map shows about $50 \mathrm{ft}(15 \mathrm{~m})$ of relief on the surface of the sand sequence beneath WMA A-AX. The Hanford formation sand sequence thickens from about $90 \mathrm{ft}(27 \mathrm{~m})$ in the east to greater than $200 \mathrm{ft}$ $(61 \mathrm{~m})$ in the west at WMA A-AX.

The Hanford formation upper gravel sequence overlies the Hanford sand sequence. This sequence is equivalent to the upper gravel sequence of the Hanford formation of Lindsey (1992), to the Hanford formation H1 sequence of Lindsey et al. (1994), and to the outburst flood deposits-gravels (Qfg) of Reidel and Fecht (1994). The upper gravel sequence is described on borehole logs of cuttings and samples from the WMA A-AX area as predominantly interbedded sands, gravelly sands, and sandy gravels. Individual beds are up to about $50 \mathrm{ft}(15 \mathrm{~m})$ thick. Thin silt lenses up to $4 \mathrm{in}$. $(10 \mathrm{~cm})$ thick are common but not abundant. The silt lenses can not be correlated among boreholes due to the coarse 5-foot sampling

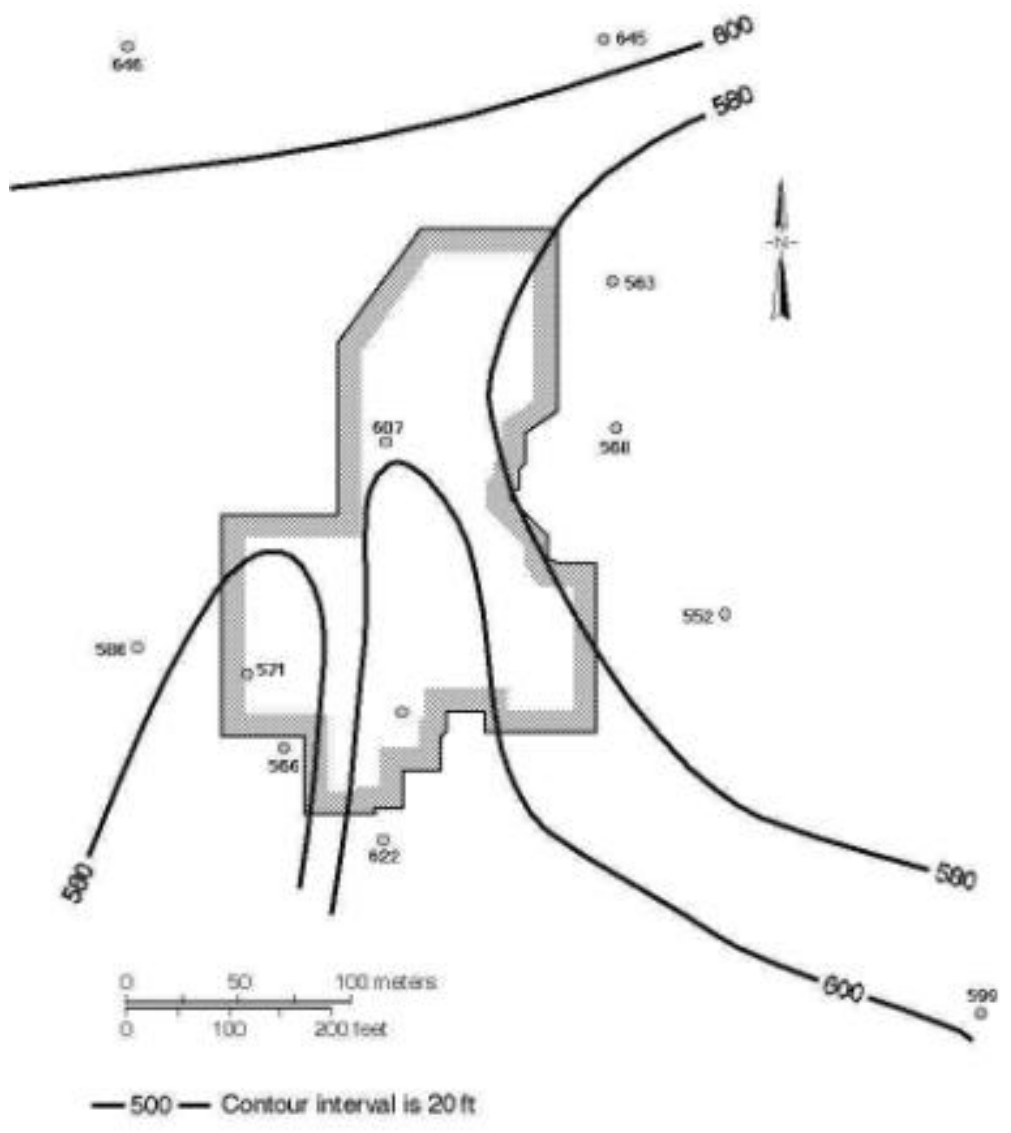

Figure 2.6. Structure Contour Map of the Top of the Hanford Formation Sand Sequence (shaded outline denotes A-AX Tank Farm boundaries) 
interval and the lack of high quality resistivity logs. Also, the silt lenses are not reflected in the available moisture data, which were obtained from grab samples every $5 \mathrm{ft}(1.5 \mathrm{~m})$. Calcareous zones occur in the upper gravel sequence and are recognized by reaction with hydrochloric acid and not by discrete calcareous particles or cement. Like the silt lenses, the calcareous zones cannot be correlated between boreholes.

Based on observations of outcrop and intact core samples, the Hanford formation upper gravel sequence is interpreted as high-energy, graveldominated facies interbedded with lenticular and discontinuous sand-dominated facies. Plates 1 through 3 show that the maximum thickness of the Hanford upper gravel sequence beneath WMA A-AX is about $127 \mathrm{ft}(39 \mathrm{~m})$ in borehole 299-E24-19. The sequence appears to thin to the north where it is only $20 \mathrm{ft}(6 \mathrm{~m})$ thick in borehole 299-E27-2 and is absent in borehole 299-E26-6 where it was either never deposited, was subsequently eroded, or the depositional environment changed such that the equivalent sediment is finer grained.

Within the single-shell tank farms, the upper 55-ft (17-m) of material is backfill consisting predomi nantly of pebbles and very coarse to coarse sand of the Hanford formation upper gravel sequence that was excavated in preparation for tank construction. The excavated material was subsequently used as backfill around the tanks. Outside the tank farms in undisturbed areas, the upper gravel sequence is overlain by a variable thickness from 0 to $\sim 15 \mathrm{ft}(\sim 5 \mathrm{~m})$ of Holocene eolian sediment.

\subsubsection{Aquifer Properties}

This section provides information on the current nature of the unconfined uppermost aquifer in the immediate region of WMA A-AX. Aquifer properties were determined from the stratigraphic interpretations, current water elevations, previous aquifer tests, and from the regional groundwater table provided in Hartman (1999).

The water table lies in basal gravels currently interpreted as Ringold Formation Unit A. As explained in Section 2.4.2, there is some ambiguity as to the location of the Hanford/Ringold contact in this area with respect to the water table. The aquifer thickness, based on data from well 299-E25-2 (see Figure 2.4), which extends to basalt, is approximately $89 \mathrm{ft}(27.1 \mathrm{~m})$. The lithology within the aquifer is dominantly a sandy gravel ranging from cobble to boulder-sized clasts. There is no evidence of cementing, and consequently, permeability should be high and relatively homogeneous within the aquifer.

The groundwater project recently switched the datum to which water levels are referenced (Hartman 1999). In the past, water levels were referenced to the NGVD29 datum. The NGVD29 datum was chosen originally because the bulk of the wells used on site could be referenced not only to this datum but to a specific survey called NGVD29-2. For areas the size of a WMA, there is no effect from switching to the NAVD88 datum. However with the datum change, there was also a switch in surveys. Many wells are now referenced to one of two surveys, with elevations referenced to NAVD88, both more recent surveys than NGVD29-2.

The water table is extremely flat across the 200 East Area, and in areas with flat water tables the choice of surveys may actually affect the relative position of the water elevation in a well with respect to 
other network wells. Since water elevations are the only data set used at the DOE Hanford Site to determine flow direction, a switch in the relative water elevations of wells used to determine direction could affect the interpretation of the flow direction.

For example, Figure 2.7 shows the hydrographs for four RCRA network wells and one older well 299-E25-2, that are currently used to monitor the water table at WMA A-AX referenced to NGVD29-2. Spurious data were removed. Figure 2.8a shows the same 'depth to water' data as Figure 2.7 but referenced to NAVD88 except for well 299-E24-20. For this well, the NAVD88 reference elevation was calculated from the original NGVD29-2 elevation.

Except for well 299-E25-46, the wells appear to be almost unaffected by switching surveys, demonstrating repeatability of the elevation values. The reference elevations from these wells, therefore, are probably reliable. Although the absolute difference is small, the relative position of the water table in well 299-E25-46 switches from being high in Figure 2.7 to being lower with respect to the other wells in Figure 2.8a. This difference is enough to demonstrate some degree of nonrepeatability. Because of this ambiguity in relative position, water elevations from this well were not used to determine flow direction. The hydrograph in Figure 2.7 is using a survey conducted in the early 1990s, whereas the hydrograph in Figure 2.8 uses a survey from the late 1990s.

A hydrograph of the remaining four wells gives a consistent picture of relative water elevations between the four wells over time (Figure 2.8b). The flow direction appears to be almost due east to just north of east. Based on this hydrograph, well 299-E24-20 is the upgradient well, while well 299-E25-40 is the downgradient well. The water levels in wells 299-E25-2 and 299-E25-41 are nearly at the same elevation. This scenario results in a generally eastward flow direction across the site.

Another well, 299 E24-19, was eliminated from the analysis because results from this well form a slight trough between E24-20 and E25-46. The water elevations in this well are low regardless of which survey is used, which has confused interpretation of the flow direction in the past. Based on recent findings with vertical borehole deviations, this well may be slightly out of plumb, explaining the abnormal trough. Consequently this well was eliminated from the network for flow direction determinations until gyroscope corrections are available.

Unfortunately, the original groundwater monitoring network, which is still in use today, was designed for a narrowly focused southwest flow direction. The consequences of having an east flow direction on the RCRA network compliance is discussed more fully in Section 4.3. However, as can be seen from Figure 1.2, the current monitoring wells are not placed to provide adequate upgradient/downgradient coverage for this WMA for an easterly flow direction. Well 299-E25-40 is too far north to provide much coverage, which leaves well 299-E25-41 as the only functional downgradient well.

The rate of groundwater flow is calculated for a homogeneous, isotropic aquifer using the Darcy equation (Hartman 1999) incorporating an effective hydraulic conductivity, the gradient across the site and the porosity of the sediments in the aquifer. Currently, there is a discrepancy in reported hydraulic conductivity values for the area. Values are estimated between 24 and $110 \mathrm{ft}(7.3$ and $33.5 \mathrm{~m})$ per day 


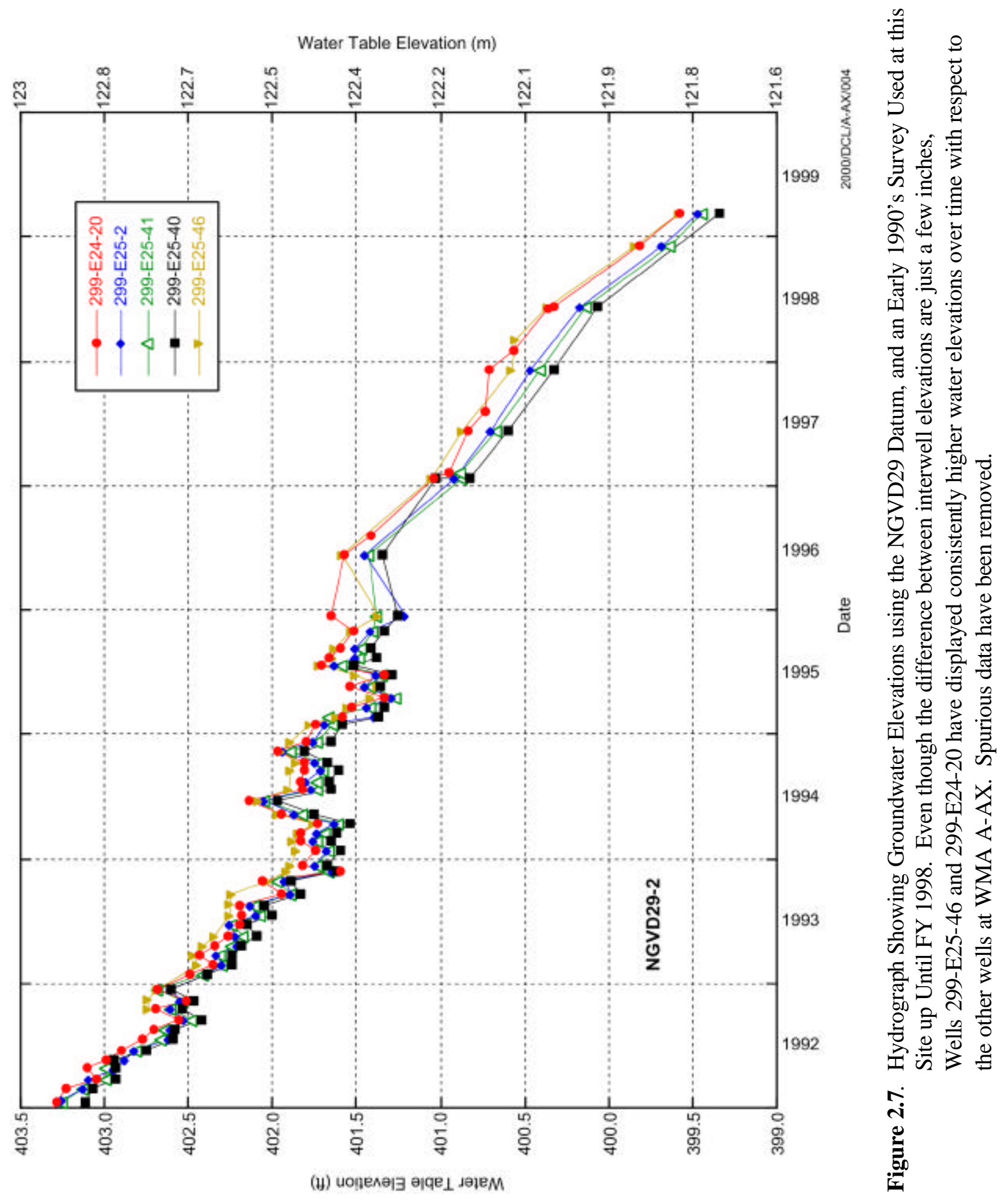




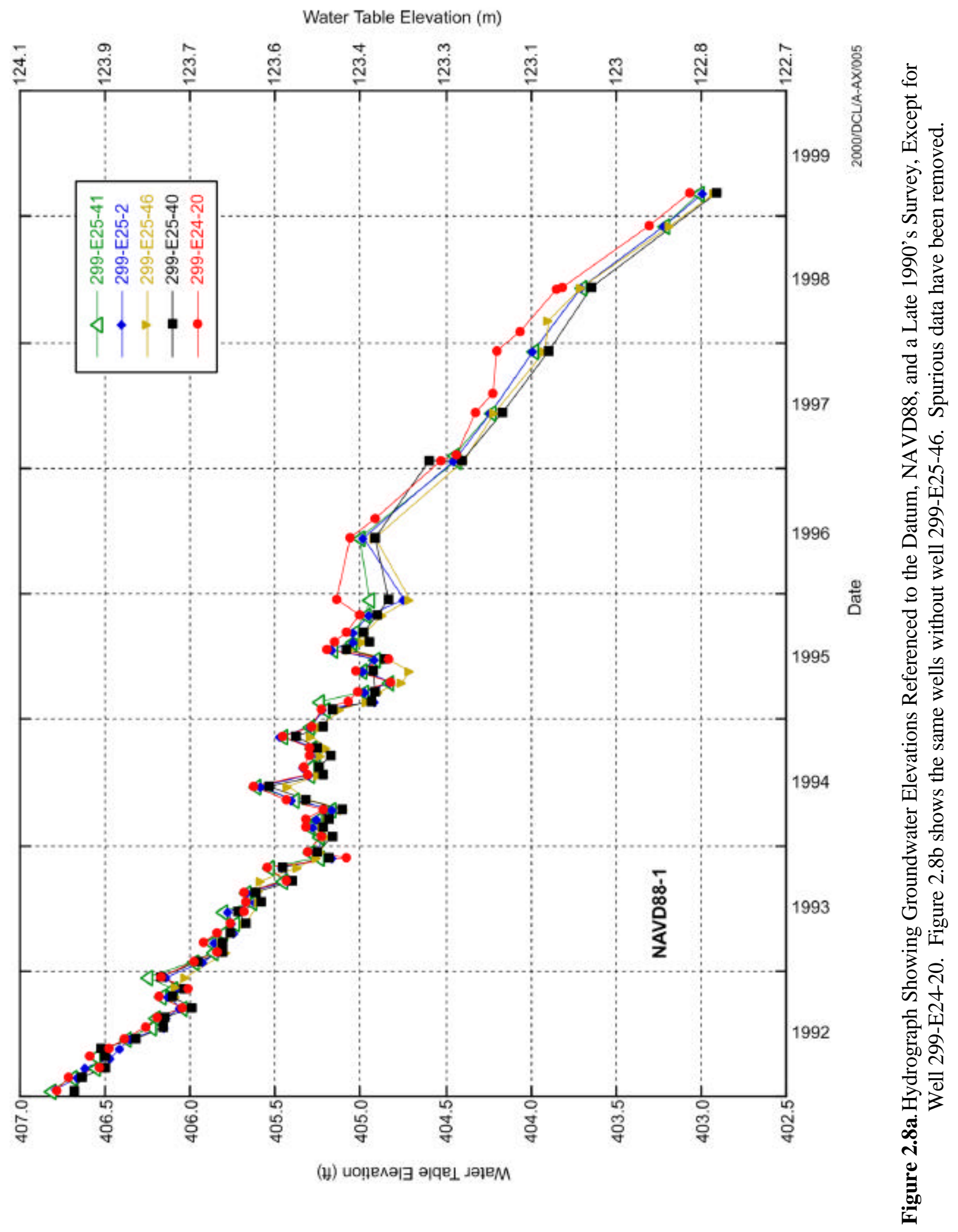




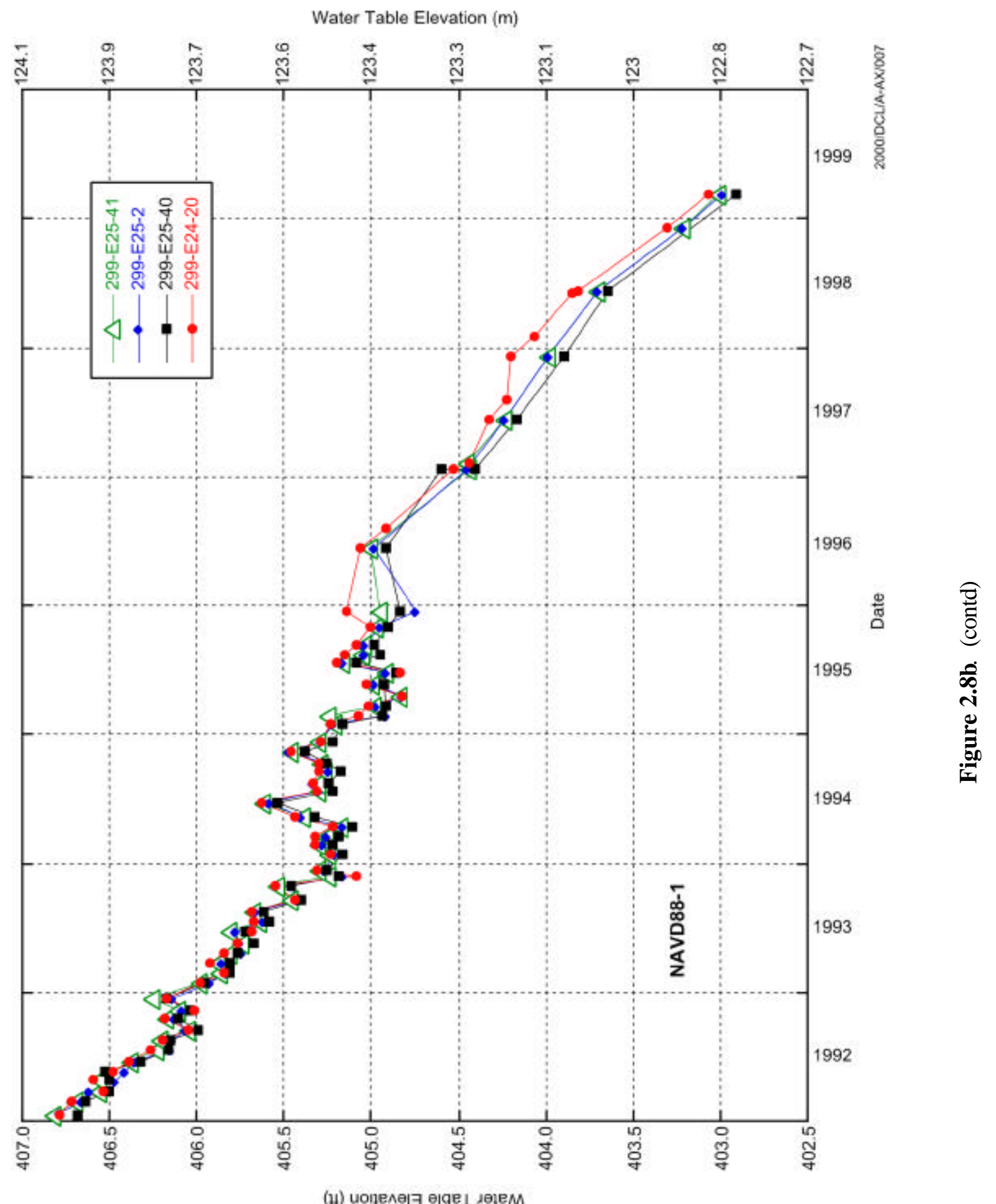

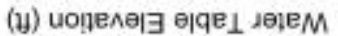


based on slug injection/withdrawal tests. Higher values of $6,500 \mathrm{ft}(1,981 \mathrm{~m})$ per day are reported based on pumping tests for the area (Newcomer et al. 1990; Connelly et al. 1992). In the FY 1992

hydrogeologic model for the 200 East Area, values of 6,200 to 6,500 ft (1,889.8 to 1,982 m) per day are reported at WMA A-AX (Connelly et al. 1992). Trent (1992) reports conductivities that range from $8,264 \mathrm{ft}(2,518.9 \mathrm{~m})$ per day to $6,500 \mathrm{ft}(1,982 \mathrm{~m})$ per day for wells in the immediate area of WMA AAX. Finally, Hartman (1999) reported hydraulic conductivities that range from 33,000 ft (10,000 m) per day to $9,843 \mathrm{ft}(3,000 \mathrm{~m})$ per day for Hanford sediments. The low results from slugs tests are likely inherent in the method. The test has a limited areal extent (i.e., interrogates a low volume), applies a limited stress to the aquifer and is valid over a limited range of conductivities (Thorne and Newcomer 1992).

Porosity is generally estimated to be about $30 \%$ for unconsolidated, coarse grained sediments at the DOE Hanford Site (Hartman 1999). Because it has not been possible to collect intact core from the aquifer during past drilling, direct methods of determining porosity have not been used. The lack of direct measurements combined with the cobble to boulder grain size of the aquifer, $30 \%$ may be an underestimated.

Using NAVD88-1, water elevations across WMA A-AX vary from 402.9 to $403.1 \mathrm{ft}$ (122.80 to $122.86 \mathrm{~m})$ or $2.4 \mathrm{in} .(6.1 \mathrm{~cm})$. The local gradient between well 299-E25-41 and 299-E24-20 is 0.000078 based on March 1999 water levels. Based on hydraulic conductivity values from pumping tests, the effective flow rate at WMA A-AX is estimated to be between 2.2 and $2.6 \mathrm{ft}(0.67$ to $0.79 \mathrm{~m})$ per day. This equates to 803 to $949 \mathrm{ft}$ ( 245 to $289 \mathrm{~m}$ ) of groundwater movement per year. However, the Hanford formation is known to contain coarse gravel channels and other sedimentary features that may produce preferential groundwater flow paths. Consequently, a flow velocity of $2.6 \mathrm{ft}(0.79 \mathrm{~m})$ per day may be low if such preferred flow zones are identified.

Currently for RCRA network wells, screened intervals within the aquifer range from 7.2 to $14.8 \mathrm{ft}$ ( 2.2 to $4.5 \mathrm{~m})$ thick. The rate of water table decline has increased from $\sim 1.0 \mathrm{ft}(\sim 30 \mathrm{~cm})$ per year during the period of mid- 1996 through 1997, to $\sim 1.7 \mathrm{ft}(\sim 51 \mathrm{~cm})$ per year from mid-1998 to March 1999. If this current rate continues, three of the RCRA compliant wells at WMA A-AX with less than $10 \mathrm{ft}(3 \mathrm{~m}) \mathrm{of}$ water may become unusable in less than six years.

At present, the flow direction and rate at WMA A-AX is poorly understood. This may be due, in part, to the artificial recharge of the aquifer, which occurred during the last 50 years when waste effluent was discharged to the subsurface. Since 1995 when most liquid discharges to the ground ceased, the water table has dropped to near pre-Hanford levels. The original local flow direction was likely in the direction of the Columbia River, easterly to southeasterly. The combination of an exceptionally flat water table, decreasing water levels and changing local flow directions complicates groundwater monitoring at WMA A-AX.

\subsection{Groundwater Chemistry}

This section provides historic information on the results of RCRA groundwater monitoring at WMA A-AX. Routine interim detection groundwater sampling began at WMA A-AX in FY 1992. There have 
been no exceedences of indicator parameters at this site during this time. Conductivity values generally range from 220 to $300 \mu \mathrm{mhos} / \mathrm{cm}$, reflecting changes in sulfate, nitrate and chloride concentrations. Calcium and sodium are the principal balancing cations. The critical mean for conductivity is $534.9 \mu \mathrm{mhos} / \mathrm{cm}$. During FY 1998, problems with faulty probes and calibration standards produced aberrant field conductivity results. Although these problems have been remedied, some of the conductivity data collected in FY 1998 and FY 1999 is questionable. Consequently, sulfate and nitrate were monitored closely.

The DWS of $1 \mathrm{pCi} / \mathrm{L}$ is exceeded for ${ }^{129} \mathrm{I}$ in all monitoring wells at WMA A-AX. This WMA lies within a large regional ${ }^{129} \mathrm{I}$ plume that extends to the southeast. The source is apparently associated with the PUREX cribs (Hartman 1999), and is probably unrelated to WMA A-AX since the estimated inventory for ${ }^{129} \mathrm{I}$ is relatively low.

Trends plots for nitrate, sulfate and ${ }^{99} \mathrm{Tc}$, comparing contaminant levels between the five RCRA groundwater monitoring wells, are shown in Figure 2.9. Unlike WMA B-BX-BY, where the anion chemistry is dominated by nitrate, conductivity changes at WMA A-AX are attributed to changes in sulfate concentration. For most of the wells, sulfate values range from 23,000 to $30,000 \mu \mathrm{g} / \mathrm{L}$, which is close to the Hanford Site background values reported in Johnson (1993) (about 14,000 to 60,000 $\mu \mathrm{g} / \mathrm{L}$ ). Nitrate values range from about 4,000 to $8,000 \mu \mathrm{g} / \mathrm{L}$, which falls within the ranges of background values of 3,200 to 12,000 $\mu \mathrm{gL}$ for the Hanford Site (Johnson 1993). The DWSs for nitrate and sulfate are $45,000 \mu \mathrm{g} / \mathrm{L}$ and $250,000 \mu \mathrm{g} / \mathrm{L}$ respectively.

Sulfate concentrations above background values are found in two wells, 299-E25-40 and 299-E25-41, where values reach about $70,000 \mu \mathrm{g} / \mathrm{L}$. Historically, these wells were listed as upgradient for WMA A-AX indicating that the sulfate plume would be moving in from the northeast. But as shown in Section 2.4, the current groundwater flow direction may be toward the east. These two wells are then downgradient of the WMA, not upgradient. Regardless of the flow direction, sulfate concentrations in these wells are well below the DWS of $250,000 \mu \mathrm{g} / \mathrm{L}$.

Nitrate concentration in well 299-E24-20 is about 37,628 $\mu \mathrm{g} / \mathrm{L}$, which is above the maximum background value of 12,000 $\mu \mathrm{g} / \mathrm{L}$ (Figure 2.10). This well is located south of the 244-AR Vault upgradient of the 241-A Tank Farm. Nitrate values rose from $6100 \mu \mathrm{g} / \mathrm{L}$ in February 1996 to 37,628 $\mu \mathrm{g} / \mathrm{L}$ in February 1998. Although there is no elevated ${ }^{99} \mathrm{Tc}$ associated with this increase in nitrate, there is a distinct correlation with tritium. Tritium values rose from 4,180 pCi/L in February 1996 to about 7,200 pCi/L in February 1998. Tritium values at the WMA range from 2,800 to $4,000 \mathrm{pCi} / \mathrm{L}$. The DWS for tritium and nitrate are $20,000 \mathrm{pCi} / \mathrm{L}$ and $45,000 \mu \mathrm{g} / \mathrm{L}$, respectively. This WMA is located regionally in an area with little to no anion or tritium contamination, although tritium was reported at $6,800 \mathrm{pCi} / \mathrm{L}$ to the west at the 216-A-9 crib.

The most prevalent groundwater contamination issue at WMA A-AX is elevated chromium, nickel, and manganese observed in well 299-E24-19 (Figure 2.11). Chromium has sporadically been in exceedence of the $100 \mu \mathrm{g} / \mathrm{L}$ DWS since FY 1991. Values range from $140 \mu \mathrm{g} / \mathrm{L}$ in early FY 1994 to $2,820 \mu \mathrm{g} / \mathrm{L}$ in October 1998. The concentration dropped to $707 \mu \mathrm{g} / \mathrm{L}$ in December 1998. Nickel and 



Figure 2.9. Trend Plots of Nitrate, Sulfate, and Technetium-99 for WMA A-AX 


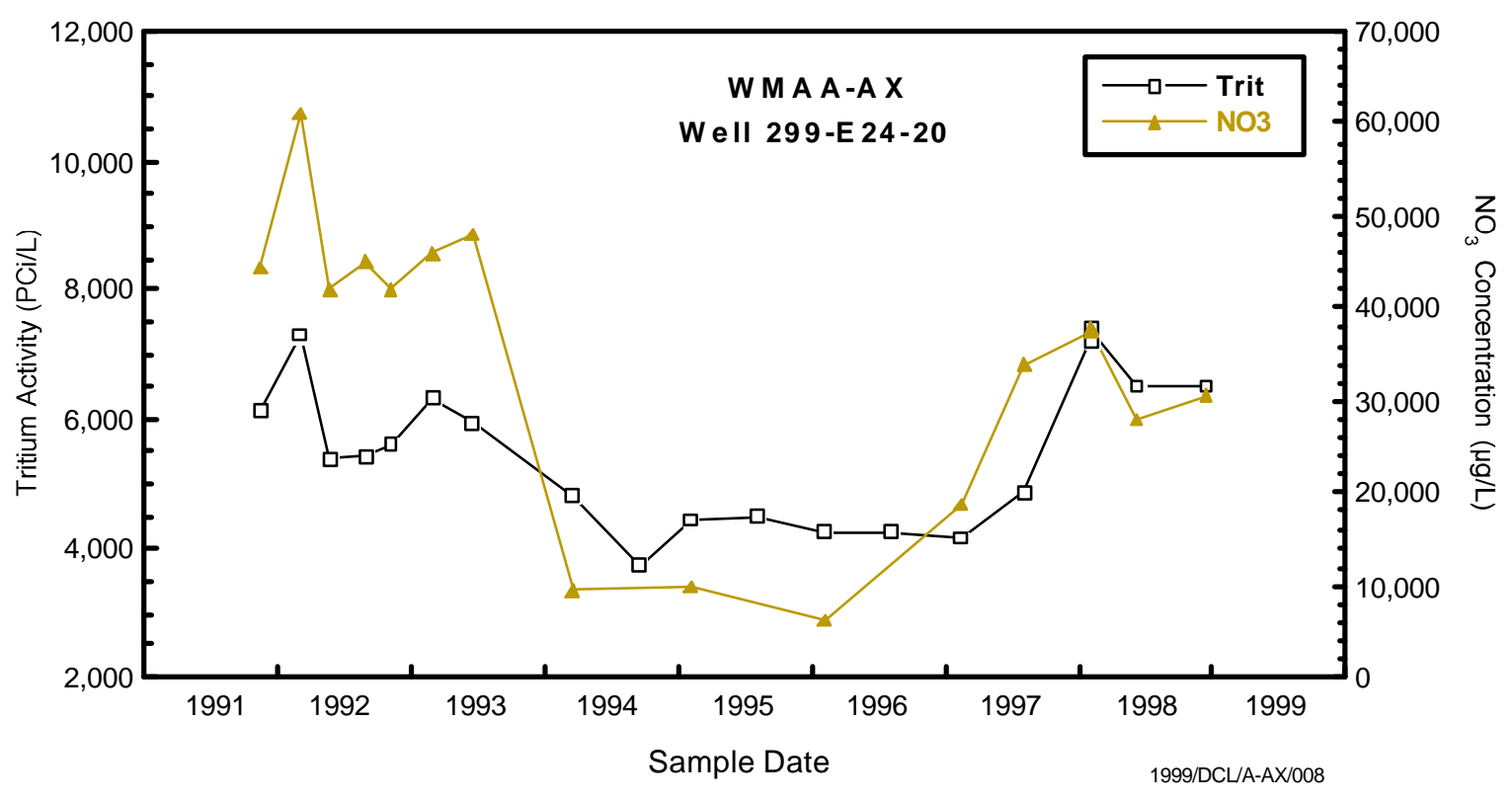

Figure 2.10. Trend Plots for Nitrate and Tritium for Well 299-E24-20 Located South of the 244-AR Vault and West of the 241-A Tank Farm

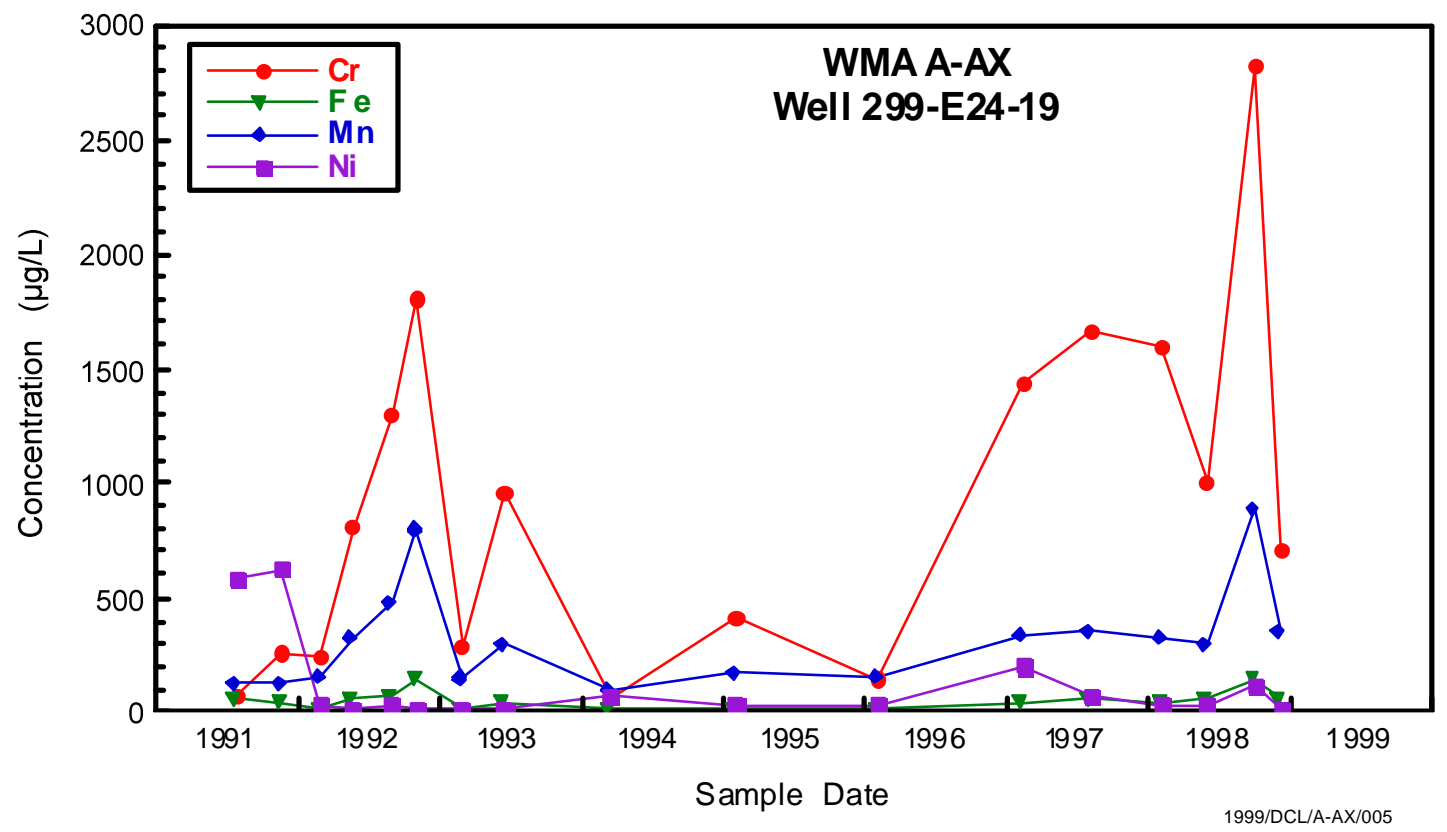

Figure 2.11. Trend Plots for Filtered Chromium, Nickel, Manganese, and Iron for Well 299-E24-19. These data are from filtered samples. 
manganese are also in exceedence of the $100 \mu \mathrm{g} / \mathrm{L}$ and $50 \mu \mathrm{g} / \mathrm{L}$ DWSs, respectively. In October 1998, the maximum concentrations of $883 \mu \mathrm{g} / \mathrm{L}$ for nickel and $141 \mu \mathrm{g} / \mathrm{L}$ for manganese were observed. Historically, iron only slightly correlates with chromium except for the recent October 1998 maximum.

Nitrate concentrations in well 299-E24-19 also increased in October 1998 from 3,320 $\mu \mathrm{g} / \mathrm{L}$ to $7,171 \mu \mathrm{g} / \mathrm{L}$. This is the first occurrence of any nonmetal constituents correlating with changes in chromium in this well. Because there are no other correlations with other constituents at this well except the metals, nickel, and manganese, and no other local occurrences of chromium have been documented in other wells, the elevated metals are, most likely, due to corrosion of the screen. However, a camera survey is planned to ascertain the condition of the screen. Also, if the screen and/or casing is the source of the metals, the first water from the well should have a greater concentration of metals, and concentration should decrease as the well is pumped. Further sampling is required to address the significance of the slightly elevated nitrate.

The only other contaminant issue of concern at WMA A-AX is the elevated ${ }^{99} \mathrm{Tc}$ observed in well 299-E25-46 during FY 1997 (Figure 2.9). Technetium-99 concentrations rose from $111 \mathrm{pCi} / \mathrm{L}$ in August 1996 to $374 \mathrm{pCi} / \mathrm{L}$ in August 1997. Values fell to $112 \mathrm{pCi} / \mathrm{L}$ by December 1997. The December 1998 value is $36 \mathrm{pCi} / \mathrm{L}$ (Figure 2.12). These concentrations are below the DWS of $900 \mathrm{pCi} / \mathrm{L}$. The gross beta value for the same dates shows a corresponding increase.

It appears that ${ }^{99} \mathrm{Tc}$ has been increasing in well 299-E25-46 since 1994. This increase in ${ }^{99} \mathrm{Tc}$ concentrations correlates with a rise in nitrate values during the same time period. The correlation was not noticed until late 1997 because of the different sampling frequencies for ${ }^{99} \mathrm{Tc}$, (semi-annual) and nitrate, (annual). Also, with the coarse temporal sampling, the timing of the true maximum concentrations of either constituent is not defined. Corresponding increases observed for sulfate (Figure 2.9) over the same time interval, provide further corroboration that the ${ }^{99} \mathrm{Tc}$ peak is a true departure accompanied by co-contaminants.

Based on the FY 1997 events observed at WMA B-BX-BY, where ${ }^{99} \mathrm{Tc}$ concentrations rose from values in the 100 's of $\mathrm{pCi} / \mathrm{L}$ to $12,000 \mathrm{pCi} / \mathrm{L}$ in less than 4 months, it was decided to temporarily increase the monitoring frequency at WMA A-AX (Narbutovskih 1998). However, it appears that contaminant levels have returned to stable concentrations, and the site was placed back on semi-annually monitoring in early FY 1999.

The background information provided in this section is used to identify monitoring goals specific to WMA A-AX. An understanding of the operational history of the tank farms and surrounding facilities along with the subsurface geology and historic groundwater chemistry is used to construct the conceptual model for this WMA, presented in the next section. 


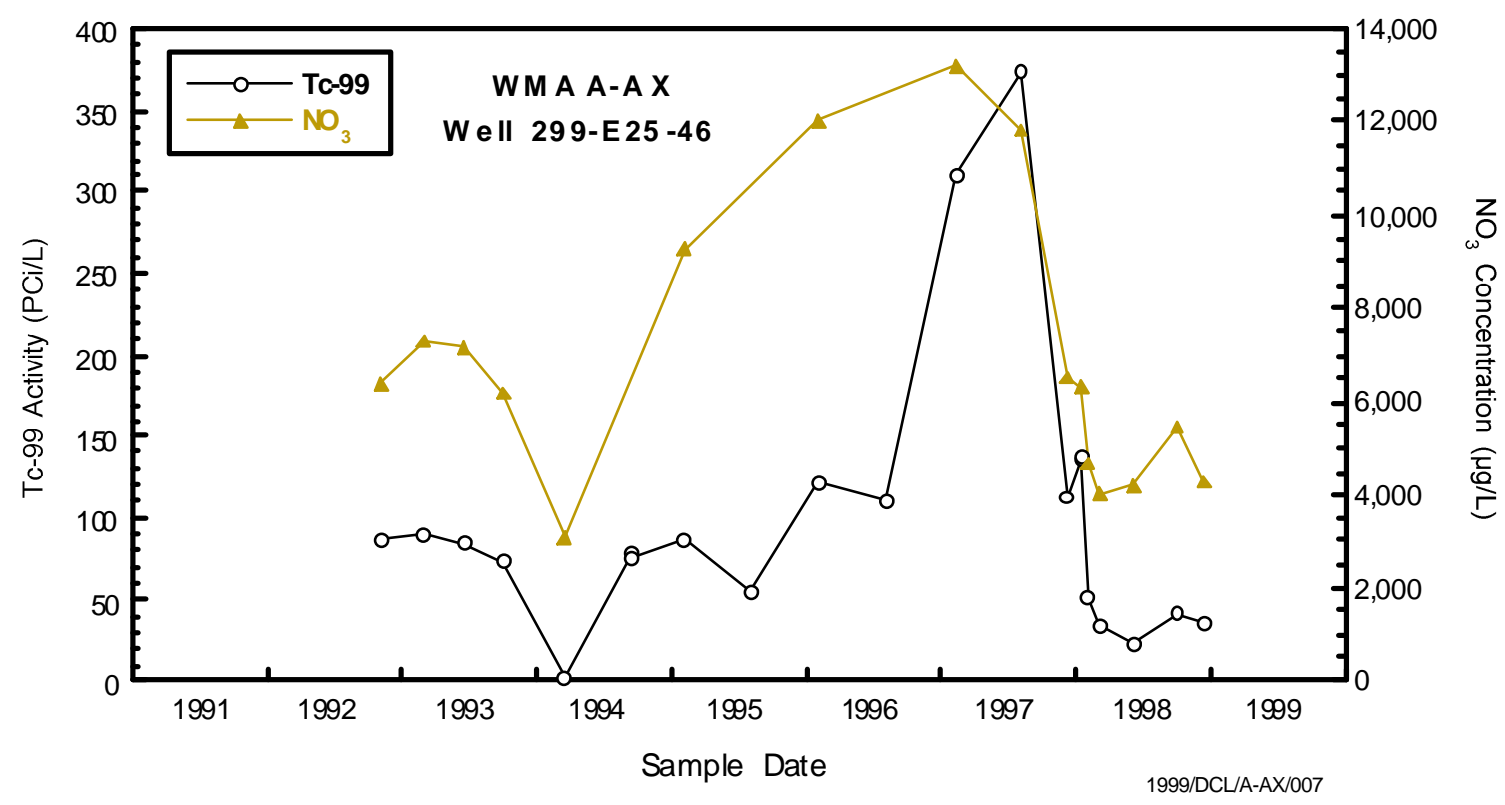

Figure 2.12. Trend Plots for Well 299-E35-46 Comparing the FY 1997 Data for Technetium-99 and Nitrate 


\subsection{Conceptual Model}

The purpose of the conceptual model is to explore the complexity and spatial/temporal relationships of three important parameters: the contamination source, the driving force, and the migration pathway. Determinations of contaminant sources are facilitated by use of a conceptual model that integrates these three parameters. Such a qualitative model can also be used to guide monitoring network design. The model presented here includes the general waste chemistry, the tank farm settings, and the hydrogeology of the unconfined aquifer. In addition, the residual contaminant plumes along with the vadose zone migration pathway are qualitatively depicted. Pertinent aspects are discussed below.

\subsection{Contaminant Sources}

A graphical summary of the physical characteristics and mechanisms that could potentially affect the generation and transport of contamination at Waste Management Area (WMA) A-AX to the groundwater is presented in Figure 3.1. Various possible contamination sources are shown. The red represents liquid waste at the time of an initial leak occurring from a tank, a waste transfer line, or a surface spill. The color shading, from red to orange to yellow, depicts contaminant migration since the initial leak to the present plume location in the vadose zone. The color change may represent either a chemical reaction of the waste with mineral phases in the soil or adsorption of relatively immobile waste constituents on to the soil grains le aving the mobile constituents dissolved in the pore water. Also shown is the interaction of fresh water migrating from the surface, moving the residual waste in the vadose zone plumes to the groundwater. This is shown as blue water interacting with residual yellow waste in the pore water to form migrating green waste. In this case, the residual vadose zone plumes act as distinct and different sources of contamination than the waste material in the tanks.

In the following text, the sources of contamination in and around WMA A-AX and the surrounding facilities are discussed as they relate to this general conceptual model. The schematic depicts possible contamination sources in the vicinity of WMA A-AX. Viable migration pathways are shown that hazardous wastes could take from a source to a monitoring well. Driving forces are also illustrated as the most likely mechanism for carrying tank associated waste constituents through the vadose zone to the groundwater.

Most tanks in WMA A-AX have no appreciable liquid left, and consequently there is little risk that new leaks could occur from these tanks. To reduce the risk of additional leaks from the tanks, an interim stabilization program is instituted at the single-shell tank (SST) farms. The objective is to remove as much liquid from the tanks as possible. As of February 1999, all tanks in WMA A-AX, except tanks 241A-101 and 241-AX-101, are listed as interim stabilized. Interim stabilized means a tank contains less than 50,000 gals $(189,271 \mathrm{~L})$ of drainable interstitial liquid and less than 5000 gals $(18,927 \mathrm{~L})$ of tank supernate (Hanlon 1999).

There are two tanks, however, that do contain significant volumes of liquids, 241-A-101 and 241-AX-101. The former has 721,000 gals $(2,729,282 \mathrm{~L})$ of drainable liquid while the latter contains 


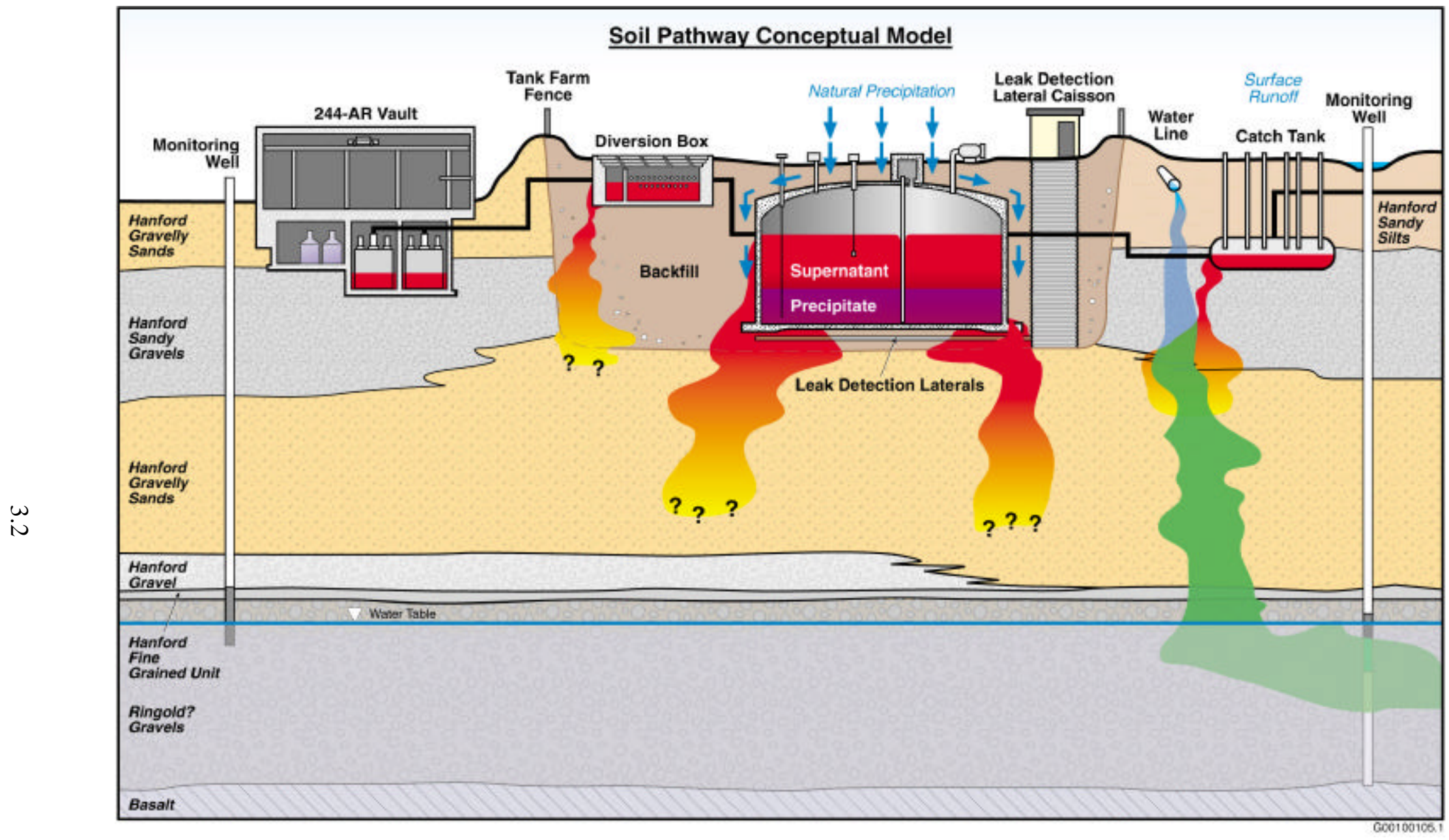

Figure 3.1. Conceptual Model for WMA A-AX. This schematic depicts possible contamination sources in the vicinity of WMA A-AX. Viable migration pathways are shown that hazardous wastes could take from a source to a monitoring well. Driving forces are also illustrated as the most likely mechanism for carrying tank associated waste constituents through the vadose zone to the groundwater. 
558,000 gals $(2,112,260 \mathrm{~L})$ (Hanlon 1999). Although each of these tanks contains at least twice as much liquid waste as any other SST on site, both are considered sound tanks. These tanks will be scheduled for liquid removal by either saltwell pumping or sluicing retrieval efforts. Consequently, unless either 241A-101 or 241-AX-101 tank leaks, tank waste contamination in the groundwater should be related to either remobilization of residual vadose zone plumes or leaks associated with liquid waste transfers.

\section{Tank Leaks}

Some leaks at WMA A-AX appear to be related to tank construction. Apparently, these tanks leaked from failed welding joints at the heel of the tanks. Unlike the earlier 100-series tanks, which have rounded steel reinforcing "knuckles" connecting the tank wall to a dished base, the tanks at WMA A-AX have flat bottoms forming right angles at the welded heel joint. The concentration of stresses at the heel when the tanks were loaded and heated caused failure of the joints. Plutonium-Uranium Extraction (PUREX) waste was discharged to the tanks as alkaline slurries with a $\mathrm{pH}$ of 9 or higher. Another site problem was corrosion at the liquid level of the waste residing in the tank. Other regions of failures are the joints where the intake/outtake lines or cascade lines were attached (Caggiano 1991). The effects of the various leak types are illustrated in Figure 3.1.

Of the 10 tanks located within the two farms, half are confirmed or assumed leakers (Hanlon 1999). A maximum leak volume of 296,000 gals $(1,120,482 \mathrm{~L})$ is reported for the WMA A-AX tanks. Small leaks (500 to 8,000 gals [1,893 10 30,283 L] ) have been reported for four of the tanks with most of the waste volume leaked to the soil from 241-A-105 (10,000 to 277,000 gals [37,854 to 1,048,559 L] ). These volumes do not include leaks from transfer lines or other ancillary equipment. Surface spills and overflow amounts are also excluded. Consequently, reported leak volumes must be considered a minimum of the total tank-related liquid released within the tank farm boundaries.

An 8-ft bulge (2.4 m) developed in the bottom of tank 241-A-105 prior to rupture as a result of the 1965 steam explosion (Westinghouse Hanford Company [WHC]-MR-0264). A significant portion of the leaked waste from this tank may have been cooling water added to prevent further tank deterioration. Interpretation of gross gamma logs run in surrounding dry wells and laterals beneath the tank after the initial steam explosion indicated that gamma-emitting radionuclides migrated into the soils forming low activity plumes under the tank. From the logs, it appeared that at least one leak was located at the heel joint of the liner with contaminants penetrating vertically into the soil beyond the $125-\mathrm{ft}$ depth (38 $\mathrm{m})$ of the dry wells (Caggiano 1991).

More recently, results from spectral gamma logs in dry wells near tank 241-A-105 (U.S Department of Energy [DOE]/GJ-Han-110 1998) indicate only moderate gamma-ray activity around this tank. The logging report states that ${ }^{137} \mathrm{Cs}$ and ${ }^{154} \mathrm{Eu}$ are detectable to $15 \mathrm{ft}(4.6 \mathrm{~m})$ in dry wells. Contamination found between 15 and $55 \mathrm{ft}$ (4.6 to $16.8 \mathrm{~m}$ ) may have been brought in during drilling activities when these wells were deepened. In one dry well located near the northwest side of the tank, ${ }^{137} \mathrm{Cs}$ contamination was found between 75 and $85 \mathrm{ft}(22.9$ and $25.9 \mathrm{~m})$. This plume is located in the vicinity of anomalous radioactivity originally detected in the laterals underneath the 241-A-105 tank. Other than these isolated occurrences, there does not appear to be significant residual gamma-source waste left in the vadose zone at this SST farm to act as a source for groundwater contamination. 
It should be realized, however, that if the main migration pathways are narrow, vertical, high permeability conduits directly beneath the tank, current subsurface characterization techniques may not present an accurate image of residual vadose zone plumes. Logging reports from WMA S-SX indicated very little vadose contamination around tank 241-SX-115. But recent drilling results have revealed the highest ${ }^{99} \mathrm{Tc}$ results in groundwater yet reported for the Hanford Site. The magnitude of the estimated inventory lost to the soil column, and the structural history of the tank do not coincide with the logging result. It is unlikely that the logging results are incorrect, but more likely that contaminant migration pathways were nearly vertical and thus confined to regions closer to the tank and did not impact the immediate area around the drywells.

Spectral gamma logging was also conducted to map vadose zone plumes at 241-AX Tank Farm (DOE/GJO-HAN-12 1997). The main constituents identified are ${ }^{137} \mathrm{Cs},{ }^{60} \mathrm{Co},{ }^{154} \mathrm{Eu}$, and ${ }^{125} \mathrm{Sb}$. These radioactive contaminants mark the location of residual tank-related waste. Results indicated that vadose zone plumes are small, isolated occurrences more likely caused by surface spills or pipeline leaks.

Migration of contamination by infiltrating surface water, however, could transport some of the mobile fraction of tank waste to groundwater, as illustrated by the transition from red/yellow to green under the catch tank in the conceptual model (Figure 3.1). Surface water leaks, spills or ponded precipitation that encounter residual vadose zone waste in the pore liquids may cause this waste to move rapidly down in near-vertical, high permeability channels, spreading the contamination to new regions. Waste liquid with mobile constituents from this scenario would tend to have some lateral movement by capillary forces if fine-grained sedimentary layers such as silt-rich zones are encountered. However, details of the subsurface geology discussed in Section 2.4 indicate few discrete silt layers on which lateral spreading could occur. Therefore, it is not expected that lateral migration is as important at WMA A-AX as it may be in the 200 West Area.

\section{Non-Tank Sources}

Surface spills of waste liquids have occurred in the SST farms at various times in the past. The existence of concentrated gamma-emitting radionuclides close to the surface in 241-A and -AX Tank Farms confirm the presence of shallow vadose zone plumes associated with spills (DOE/GJO-HAN-12 1997). The near surface contamination is probably associated with leaks from transfer lines, diversion boxes, catch tanks, and vaults. Given a sufficient driving force, any of these residual plumes could become a source for groundwater contamination.

In addition, there are a series of liquid effluent disposal facilities surrounding the WMA. Some of these facilities are located in Figure 1.2. The cribs, trenches, and french drains were built to dispose of liquid waste directly to the soil column. Although the bulk of the disposed liquid was condensate and

condenser cooling water, depleted uranium waste, cell and stack drainage waste, and tributyl phosphate (TBP)kerosene organic waste from PUREX were also discharged to the soil column. The volumes of liquid effluent discharged to the various facilities ranged from as little as 1,600 gals $(6,057 \mathrm{~L})$ to as much as $304 \mathrm{Mgal}(1,150,765,182 \mathrm{~L})$. This practice of disposing tank-related wastes directly to the ground has resulted in 
extensive vadose zone and groundwater contamination surrounding the WMA A-AX. The presence of these large vadose zone sources complicates the task of distinguishing present day tank farm sources from adjacent past-practice disposal facility sources.

\section{Source Constituents}

Not all of the chemical species in tank waste are mobile. Depending on the solubility and concentration, some species are more able to leak from a tank and migrate through the subsurface to the groundwater. Thus it is important to consider the chemistry and fate of the waste generated at the PUREX plant and the B Plant fractionation processes, with regard to both relative concentrations and activities.

Prior to storage in the tanks, the PUREX high level, acid waste was buffered to form an alkaline slurry to minimize corrosion of the carbon steel liners. Initially wastes at WMA A-AX were primarily inorganic consisting of sodium hydroxide, sodium salts of nitrate, nitrite, carbonate, aluminate, phosphate, and hydroxides of iron and manganese. Although much of the carbon and hydrogen from the early organic solvents used in the PUREX process vaporized as $\mathrm{CO}_{2}$ and $\mathrm{H}_{2}$, Agnew (1997) reports significant concentrations of organics in these tanks in both solid and liquid phases. The radioactive components consists of first order fission products and associated daughter species. Based on analyses of sludge and supernate from 241-A-105 prior to 1965 and accounting for decay of the short-lived elements, the primary radioactive components left in the tanks are ${ }^{90} \mathrm{Sr},{ }^{137} \mathrm{Cs},{ }^{60} \mathrm{Co},{ }^{99} \mathrm{Tc},{ }^{154} \mathrm{Eu},{ }^{239,}{ }^{240} \mathrm{Pu}$, and ${ }^{241} \mathrm{Am}$ (Jansen et al. 1965; Anderson 1990). Agnew, however, shows ${ }^{90} \mathrm{Sr}$ and it daughter product, ${ }^{90} \mathrm{Y}$, as the radio active species with the greatest activity in most of the tanks at WMA A-AX.

In general, the mono and divalent metals formed insoluble compounds with the excess hydroxide to form the sludges. Thus, it is unlikely to see metals such as iron, lead, or manganese in the leaked waste. Insoluble species such as ${ }^{239,240} \mathrm{Pu}$ and ${ }^{241} \mathrm{Am}$, although present at high relative activity levels, would also tend to stay in the tanks as solids. The salt cake in these tanks is formed primarily from the carbonates and phosphates. The liquid phase of the waste is enriched in the anionic complexes such as nitrate, sulfate and pertechnetate along with the some of the organic component and tritium. Sodium and calcium are the main cations associated with these anionic phases.

Once the tank liquor has escaped to the soil, only the gamma-emitting radioactive nuclides can be detected with non-invasive logging techniques in the vadose zone. The mobile hazardous components such as nitrates and sulfates along with beta and alpha emitting radionuclides such as ${ }^{99} \mathrm{Tc}$ cannot be identified until concentrations or activities reach detectable limits in the groundwater at a monitoring well. Of the radionuclides identified above, only ${ }^{137} \mathrm{Cs}$ and ${ }^{154} \mathrm{Eu}$ were identified in the vadose zone at tank 241-A-105 (DOE/GJ-HAN-110 1998). Cesium-137, ${ }^{60} \mathrm{Co},{ }^{154} \mathrm{Eu}$, and ${ }^{152} \mathrm{Eu}$ have been identified at other locations in the vadose zone at the WMA A-AX (DOE/GJ-HAN-108 1998; DOE/GJ-HAN-109 1998; DOE/GJ-HAN-111 1998). 
Although ${ }^{137} \mathrm{Cs}$ and ${ }^{60} \mathrm{Co}$ are in the liquid phase in tank liquors, these species appear to be sorbed onto grains in the upper part of the soil column close to the leak point (Serne et al. 1998). Thus they are almost completely removed from the remaining mobile faction of migrating tank waste. This is shown in the conceptual model (Figure 3.1) as the red transitioning to yellow as adsorption occurs.

Hazardous and radioactive constituents detectable in the groundwater are likely to be those that form anionic compounds and are not readily sorbed in passing through the soils of the unsaturated zone. These compounds will move with the moisture front through the soils and can later be remobilized by subsequent renewed moisture movement such as migrating fresh water. Nitrate, sulfate, ${ }^{99} \mathrm{Tc}$, and tritium are the most likely constituents to be detected in the groundwater. Also, the organic component might be detected with analyses for total organic carbon (TOC).

During past operations, primarily condensate and cooling water were discharged to the liquid effluent facilities that surround WMA A-AX (Figure 1.2). Because those wastes are chemically different than tank waste, differentiating the two sources in groundwater might not be as complicated at WMA A-AX as it is elsewhere in the 200 East Area. The chief differences should be high tritium in condensate waste versus high levels of ${ }^{99} \mathrm{Tc}$ in tank waste. Also, many of the tanks at WMA A-AX received organic complexant wastes during the last few years of active service, which are not found in condensate waste. In addition the waste sent back to the WMA A-AX tanks from the B Plant fractionation processes was enriched in ${ }^{90} \mathrm{Sr}$ and ${ }^{137} \mathrm{Cs}$. Although the ${ }^{137} \mathrm{Cs}$ is unlikely to reach groundwater, the ${ }^{90} \mathrm{Sr}$ may if concentrations and driving force are great enough.

Recent analyses of porewater taken from contaminated soils collected at the 241-SX Tank Farm were reported in Myers et al. (1998). The data shows that nitrate is present above background down to depths of 155 feet. None of the radioactive constituents found at shallower depths $(130 \mathrm{ft}[39.2 \mathrm{~m}])$ were detected at this depth. Desorption tests on the most contaminated sediments suggest that ${ }^{137} \mathrm{Cs}$ is irreversibly adsorbed by soil grains. Thus once ${ }^{137} \mathrm{Cs}$ is removed from the migrating waste, is unlikely to be remobilized by later migrating fluids. The adsorbed phases may be permanently stored in the soil column. This would suggest that only mobile components left in pore water are capable of remobilization due to later driving forces such as infiltrating water.

\subsection{Driving Forces}

In general, there are two ways that tank-associated waste can migrate to groundwater. Either the volume of the initial leak must be large enough to reach groundwater through gravity drive and/or capillary action, or an external source of water or other liquid must be available to remobilize a residual tank-associated vadose zone plume. Since most tanks in WMA A-AX no longer contain large amounts of liquid waste, it is unlikely that a tank could currently leak enough liquid to reach groundwater unassisted. However, a leaking waste transfer line during long-term waste removal operations could result in a substantial leak. Another way might be high pressure sluicing of a tank that already has a leak point developed.

Of these two scenarios, the easiest and most likely mechanisms for driving residual vadose zone contamination to the groundwater are external water sources. For example, a two-inch raw water line 
broke in February 1978 on the east side of 241-A Tank Farm (Caggiano 1991). Before the line could be turned off, 60,000 gals $(227,125 \mathrm{~L})$ of water were released to the soil column. This large volume of water caused soil collapse in the center of the farm between tanks 241-A-102 and A-105, even though the ruptured line was on the east side of the farm.

Sources of water in the vicinity of the tanks can be either artificial (man-made) or natural. Examples of man-made water sources include nearby leaking or ruptured water lines, leaking fire hydrants or broken valves. A complex system of water and waste transfer lines exist within the farms to support farm operations. Failure of these pressurized lines, such as the February 1978 event, could result in driving tank waste to the groundwater.

Mobility of escaped waste can be increased as a result of natural recharge such as heavy rainfalls and sudden snowmelts. Johnson and Chou (1998) discuss the extent that rapid snowmelt from recent years has contributed to natural driving forces. The results of a rapid snow melt event in February 1979 are documented in Hodges (1998) with photographs showing extensive flooding in the 241-T Tank Farm. The effects of these events can be enhanced by gravel surfaces, lack of plant uptake and transpiration, and surface depressions that tend to collect and pond run-off and snow melt.

\subsection{Migration Pathways}

The water table at WMA A-AX is approximately $290 \mathrm{ft}(83.4 \mathrm{~m})$ below the surface. Consequently, much of the migration pathway from the source to the groundwater monitoring well will be in the unsaturated zone. The nature of liquid migration through this zone is not well understood, but it is highly dependent on heterogeneities and anisotropy in the soil permeability. The bulk of the sediments are highenergy flood deposits with extreme variability in grain size over vertical and horizontal intervals on the order of tens of feet. Hydraulic conductivity values would be expected to change on at least the same scale if not less. Consequently, delineating migration pathways through a thick sequence of unconsolidated sediments is a challenging task.

In the 200 East area, unsaturated sediments are primarily gravelly coarse-grained sands and sandy gravels with a few thin intermittent silt-rich units, there are no low-permeability horizons that would cause appreciable lateral spreading of infiltrating liquid under WMA A-AX. The detailed stratigraphic description provided in Section 2.4.2 and in Plates 1,2, and 3 show a vertical column of predominantly coarse sands in the vadose zone. The slight doming effect seen at the top of the Ringold formation appears to be carried through to the contact between the Hanford upper gravel and sand sequences. These subtle structures at changes in lithologies may control local flow directions for migrating liquid. However, it is not possible to model or predict specific pathways.

Studies of aqueous flow in sandboxes suggest that one common pattern of flow through unsaturated sediments is in relatively narrow, vertical fingers with some lateral spreading occurring at silty horizons. Once saturation of these horizons is reached, vertical flow commences again. Furthermore, once these vertical pathways are established with an initial infiltration event, liquids from later infiltration events will 
prefer these established channels (Stephens 1997). The cross-sections portray that the bulk of the sediments in the vadose zone should promote vertical transport of migrating fluids. The fine-grained sequence at the top of the Ringold may cause some lateral spreading at depth.

Evidence in support of this type of flow behavior in the 200 East Area comes from direct observation of infiltration tests performed at the 200E/105A Mock Tank Site (Narbutovskih et al. 1996). Electrical resistivity tomography was used to track leaking saline water from the surface to a depth of about $70 \mathrm{ft}$ $(21.3 \mathrm{~m})$. Results indicate that this type of fingering does occur. Furthermore, analysis of the infiltration rate, the time to reach depth and the total volume of water leaked indicates that a point leak of 0.13 gallons per minute $(0.49 \mathrm{~L} / \mathrm{min})$ might reach groundwater in a few months (Hartman and Dresel 1997).

The sandbox studies and the infiltration tests suggest that relatively moderate volumes of liquid ( 10,000 gals [37,854 L] ) will travel rapidly through the vadose zone in the 200 East Area possibly reaching the aquifer in some time period less than a year. The evidence for this type of migration comes from direct observation of laboratory and field infiltration tests and not from modeling studies, which are dependent on site knowledge of unsaturated hydraulic properties.

In several areas of the Hanford Site, clastic dikes exist in the subsurface. It has been suggested that these dikes may provide vertical pathways for rapid liquid migration from the surface to the groundwater. The vertical extent that one dike can extend into the subsurface is presently not known. If clastic dikes do exist under the farms, a pathway might exist that allows rapid vertical movement of fluids through at least part of the vadose zone. Other migration pathways that would allow rapid vertical flow are the outer annulus of poorly sealed or unsealed drywells within the farm boundaries. Water may enter from the surface to flow downward along the outside of the well casing if the sealant material does not properly adjoin the casing. Contamination in the vadose zone may also enter an annular space via discontinuities in the seal column, such as a "bridge" caused by careless emplacement of sealant materials, and then flow downward between the flawed seal and well casing. These wells are used for vadose zone monitoring with gamma ray logging tools and extend to depths of approximately 100 to $150 \mathrm{ft}$ (30.4 to $45.7 \mathrm{~m}$ ) below the surface.

As work progresses on the assessments of SST WMAs, more information may become available furthering our understanding of migration pathways through both the vadose zone and the sediments in the unconfined aquifer. Impacts from various driving forces may also become better understood. This conceptual model will be revised as necessary to reflect these new findings. 


\subsection{Detection Monitoring Program}

The detection monitoring program employed at Waste Management Area (WMA) A-AX was designed to detect the presence of hazardous waste constituents at the point of compliance located along the southwest side of the WMA. The current program is based on the waste inventory in the tanks and on our knowledge in the early 1990s of the local hydrogeology. In order to produce a more accurate determination of the groundwater flow direction, the monitoring well network may require a redesign that accounts for flow direction other than southwest. Coverage for the inclusion of the 244-AR vault and diversion boxes into the Part A Permit application will also be incorporated into the new monitoring design. Plans for resolving the question of flow direction are provided in Section 4.2.3 along with a tentative schedule. Until the work can be performed and new wells installed, if found necessary, the current monitoring program will continue. The detection monitoring plan presented herein contains the:

- design of basic interim status Resource Conservation and Recovery Act (RCRA)-compliant monitoring well network along with as-built diagrams of both RCRA and non-RCRA groundwater monitoring wells available for contingent assessment monitoring

- current methods employed to routinely determine groundwater flow, both rate and direction

- indicator parameters used to detect the presence of groundwater contamination

- frequency of groundwater sampling

- sampling, analysis and statistical procedures currently used for detection monitoring.

The following sections provide a discussion of monitoring objectives specific to WMA A-AX. A description of the current detection monitoring plan with suggestions of needed modifications to allow accurate and early detection of contamination from WMA A-AX is also included. Steps required to implement these modifications are provided. The RCRA-required assessment monitoring plan outline is proposed in Appendix B, with details of local well construction given in Appendix C. An explanation of the statistical calculations along with the Field Sampling Plan (FSP) and Quality Assurance Program Plan (QAPP) are provided in Appendix D.

\subsection{Objectives}

In accordance with 40 CFR 265 by reference of Washington State Administrative Code (WAC) 173303-400 (3), which describes requirements for a detection monitoring program, the general objectives of the WMA A-AX groundwater monitoring plan are to:

- monitor to detect indicator parameters, hazardous waste constituents and reaction products that provide a reliable indication of the presence of dangerous constituents in the uppermost aquifer 
underlying WMA A-AX. This includes the single-shell tanks (SSTs), diversion boxes and the 244-AR Vault.

- operate a groundwater monitoring system at the compliance point, i.e., at the downgradient wells to detect constituents that degrade groundwater quality. Provide early warning of leaks occurring at or near the surface by detection of more mobile constituents (e.g., nitrate, sulfate, and tritium) to allow timely mitigation of groundwater pollution from WMA A-AX.

- collect groundwater samples at an optimal frequency specifically determined for WMA A-AX to detect specific, mobile waste constituents and/or indicator parameters to facilitate early warning.

The manner in which these general goals are achieved at a WMA is, to some extent, dependent on site characteristics. For example, the 241-A and 241-AX Tank Farms along with the 244-AR Vault and diversion boxes are nearly surrounded with double-shell tank (DST) farms. These DST farms and the 242 A-Evaporator are currently operating facilities storing, transferring and periodically processing liquid waste. Although DST systems have never developed known leaks, the monitoring network for WMA AAX should ideally be placed to provide data that can best differentiate a SST source from a DST, evaporator, or other potential sources of contamination.

Numerous liquid discharge facilities are also located around WMA A-AX. In the past, tank-related wastes or Plutonium-Uranium Extraction (PUREX) wastes with similar constituents to the tank waste were discharged to the soil column at these facilities in quantities large enough to produce extensive present-day plumes of groundwater contamination. These plumes are mapped in and around groundwater under the WMA. Furthermore, the residual pore water under the discharge facilities is likely to harbor contamination that can act as new sources for groundwater contamination if a water driver from the surface is provided. The detection monitoring program should attempt to operate such that waste currently in the uppermost aquifer or currently being driven to the aquifer from these discharge facilities can be differentiated from a WMA A-AX source.

Site-specific goals for the groundwater monitoring program at WMA A-AX are to refine monitoring locations, sampling frequencies, and the constituent list such that it can be determined whether or not WMA A-AX is the source of the groundwater contamination. To assist in network refinement, the effici ency of the existing groundwater monitoring network may be evaluated with numerical models such as the Monitoring Efficiency Model (MEMO) (Wilson et al. 1993).

\subsection{Groundwater Monitoring Plan}

This section describes the existing interim-status groundwater monitoring network that is and will be used until the flow direction is verified and network modifications are installed. It was designed in accordance with RCRA, as presented in 40 CFR 265, Subpart F. The first section defines the monitoring network (number and locations of monitoring wells, well construction), provides the method currently used to determine flow direction/rate and evaluates the network with respect to flow direction. Monitoring issues are identified, the groundwater sampling parameters are presented with the constituent sampling frequency, and the current sampling frequency is evaluated with respect to the program objectives. Next, the efficiency of the groundwater monitoring network is evaluated and clarified, so that 
tasks can be planned that will lead to network enhancement, as needed. Finally this section describes the manner in which data are stored and retrieved, lists data interpretation methods, and provides the reporting requirements for the program.

\subsubsection{Monitoring Network}

The present network consists of five RCRA Standard wells and one older carbon-steel well (Figure 1.2). All six wells are used for water level measurements but, currently, only the five RCRA Standard wells are sampled for groundwater quality. The water level measurements are made quarterly over a one hour interval to eliminate daily earth tide effects and to reduce barometric effects due to changing atmospheric pressure.

The monitoring system at dangerous waste sites is located along the hydraulically downgradient limit of the waste management area, defined as the area on which waste is stored at the regulated unit. Monitoring wells are placed as close as reasonably possible to the WMA. As can be seen from Figure 1.2, only two wells are close to the WMA boundary. Numerous ancillary facilities are present along the perimeter of the WMA limits monitoring well sites (Figure 1.2). Utilities, both underground and overhead, water pipelines, waste transfer lines, diversion boxes, DSTs, support buildings and change trailers make it impossible to safely install a well without impacting the operation of or the access to existing facilities. The point of compliance for WMA A-AX equates an imaginary line connecting the downgradient wells.

The quarterly water level measurements are made separately from the sampling events. Sampling for groundwater quality is performed at least semi-annually as required for a site in interim detection status. If a significant increase in a site-specific contaminant is observed, the well with rising contamination may be placed temporarily on monthly monitoring to evaluate the anomaly. Normal sampling frequency will resume when the contaminant level has returned to historic background levels. Table 4.1 provides wellby-well information on sampling objective, sampling frequency, and the position of the well with respect to flow direction. Although the location of some wells with respect to flow direction is ambiguous, upgradient and downgradient wells are marked according to the southwest flow direction across WMA A$\mathrm{AX}$, as originally planned.

Table 4.1. Network Monitoring Wells

\begin{tabular}{||c|c|c|c|c||}
\hline \hline Well Name & Completion Date & $\begin{array}{c}\text { Upgradient } \\
\text { Downgradient }\end{array}$ & $\begin{array}{c}\text { Sampling } \\
\text { Objective }\end{array}$ & $\begin{array}{c}\text { Sampling } \\
\text { Frequency }\end{array}$ \\
\hline \hline $299-E 24-19$ & 1989 & Down & C, WL & SA, Q \\
\hline $299-E 24-20$ & 1991 & Down & C, WL & SA, Q \\
\hline $299-E 25-2$ & 1955 & & WL & Q \\
\hline $299-E 25-40$ & 1989 & Up & C, WL & SA, Q \\
\hline $299-E 25-41$ & 1989 & Up & C, WL & SA, Q \\
\hline 299-E25-46 & 1992 & Down & C, WL & SA, Q \\
\hline WL Water level measurement. & Q Quarterly. \\
C Chemistry monitoring. & SA Semi-annual. \\
\hline
\end{tabular}


The basic well design of the five RCRA Standard wells was set according to WAC 173-160, Minimum Standards for Construction and Maintenance of Wells. Completion dates range from 1989 to 1992. A 4-in. (10-cm) inner diameter stainless steel casing was set to within $5 \mathrm{ft}(1.5 \mathrm{~m})$ above the water table. Then $20 \mathrm{ft}(6.1 \mathrm{~m})$ of stainless steel continuous-slot screen was set from $5 \mathrm{ft}(1.5 \mathrm{~m})$ above to $15 \mathrm{ft}$ $(4.6 \mathrm{~m})$ below the water table. The open portion in the unsaturated zone was done to provide for any rises in the groundwater over time.

Above the sand pack, which surrounds the screened interval, is a two-inch annular bentonite seal that extends to within $20 \mathrm{ft}(6.1 \mathrm{~m})$ of the surface. Surface casing was set and sealed with cement from $20 \mathrm{ft}$ $(6.1 \mathrm{~m})$ to ground level. The wells were finished with a cement pad and 4 posts for well protection. The seals assure that there is no vertical communication along the outside of the borehole. Dedicated pumps are installed in each borehole. The wells are capped and locked when not in use.

Well 299-E25-2 was completed in March 1955. Although originally a carbon-steel well with an 8 inch inner diameter, it was recompleted with a 6 in. $(15.2 \mathrm{~cm})$ inner liner to a depth of $240 \mathrm{ft}(73.2 \mathrm{~m})$. Below that depth it still has the 8 in. $(20.3 \mathrm{~cm})$ inner diameter casing. When the 6 inch $(15.2 \mathrm{~cm})$ liner was set, the 8 inch casing was perforated and a grout seal placed not only between the inner and outer casing, but into the formation behind the outer casing. Thus this well is sealed down to $240 \mathrm{ft}$ (73.2 m). Details concerning the site's well constructions, location coordinates, surveyed elevation, total depth, general geologic stratigraphy and well maintenance can be found in Appendix C. Information is also provided on other wells in the area that could be monitored for the WMA A-AX. Some of these wells are located within the farm fences and therefore, would be costly to monitor. Consequently these wells are not candidates for detection level monitoring.

As described in Section 2.4, screened intervals in the water table range from 8 to $11 \mathrm{ft}$ ( 2.4 to $3.35 \mathrm{~m}$ ). If the recent increase in the rate of water level decline from $0.3 \mathrm{ft}(9 \mathrm{~cm})$ per year to almost $0.8 \mathrm{ft}(24 \mathrm{~cm})$ per year continues, some wells may require replacement within 6 years.

\section{Groundwater Flow Determination}

The current water table of the unconfined aquifer is nearly flat throughout the 200 East Area. Although this low gradient is caused, in part, by the dissipating groundwater mound under B-Pond, it is primarily due to the high aquifer transmissivity in the 200 East Area with respect to upgradient regions farther to west where transmissivity is considerably less. Before formation of the groundwater mound beneath B-Pond, the groundwater flowed regionally to the southeast towards the 300 Area. As evidenced by the large tritium plume of PUREX waste disposed to the PUREX cribs, the effective flow from the southeast corner of the 200 East is to the east and southeast at rates from 14 to $18 \mathrm{ft}$ ( 4.3 to $5.5 \mathrm{~m})$ per day (Hartman 1999).

When considering the flow for sites with small areas such as WMA A-AX, knowledge of the local flow is required to ensure proper placement of downgradient wells with respect to the waste storage units and ancillary equipment. The objective of interim detection monitoring is not to discern where 
contamination is moving across the Hanford Site but to discern if waste from the WMA is entering the groundwater. Consequently, the regional flow directions and plume trends, as evidenced over miles, can be misleading when determining the local flow across a site that is $500 \mathrm{ft}$ wide $(152.4 \mathrm{~m})$.

Currently the flow direction is determined from gradient calculations based on local water elevations. Unfortunately, across the 200 East Area, the differences in water elevation between wells are small, on the order of a few inches. The combined errors from water level measurements, survey elevations and slight borehole deviations from vertical are enough to cause uncertainties in local flow direction anywhere in the 200 East Area. As reported in Hartman (1999), water level data alone are insufficient to determine flow direction in this area. The authors of that report suggest that other information be considered to determined flow direction in the 200 East Area.

It is especially important that an adequate understanding of flow direction be obtained at WMA A-AX because of the potential risk to human health and safety related to the waste stored at this site. Because of large liquid volumes of stored waste, the proposed eventual use of sluicing to remove tank waste, and the ongoing waste transfer for interim stabilization efforts, early detection of leaking contaminants is important. Water levels may continue to yield ambiguous determinations of the local groundwater flow direction. However, other methods of determining groundwater flow rate and direction, such as direct measurement techniques, may help resolve uncertainties in this factor and thus alleviate some of the potential risks.

According to water elevations based on surveys referenced to NAVD88, the direction of flow is nearly due east. The current network was designed for a southwest flow direction with two upgradient wells (then 299-E25-40 and 299-E25-41) and only 3 downgradient wells, 299-E24-19, 299-E24-20 and 299-E25-46. As can be seen from Figure 1.2, for easterly flow, only well 299-E25-41 is clearly downgradient. Thus, if easterly groundwater flow is occurring beneath WMA A-AX, the current well network may be inadequate.

The flow rate is calculated with the Darcy equation for a homogeneous, isotropic porous medium. The current estimate is between 2.6 and $2.2 \mathrm{ft}(0.79$ to $0.67 \mathrm{~m})$ per day. As discussed in Section 2.4, the flow rate may be in excess of the rate calculated from ambiguous gradient data and the effective hydraulic conductivities. Direct measurements of flow rates based on tracer tests and plume tracking suggest flow

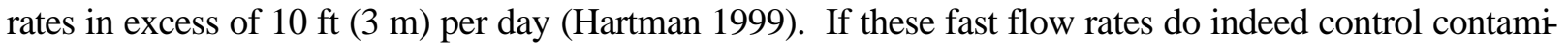
nant movement, then early groundwater detection of tank-related contaminants leaking to the uppermost aquifer is important because 241-A and 241-AX Tank Farms are the SST sites closest to the Columbia River.

\section{Network Evaluation}

Monitoring network efficiencies are evaluated for SST WMAs with the use of a simple two dimensional horizontal transport model called the Monitoring Model Efficiency Model (MEMO) (Golder 1990). This model estimates the monitoring efficiency of a network at the current compliance point by simulating a contaminant plume originating from a series of grid points within the WMAs using the Demenico-Robbins method (Demenico and Robbins 1985). The model calculates both advective flow 
and dispersion in two dimensions and determines whether the resulting plume will be detected by a monitoring well before the plume travels to some arbitrary distance beyond the WMA boundary termed the buffer zone. The ratio of the area within the WMA over which detection will occur before impacting the buffer zone to the total WMA area expresses the monitoring efficiency. The model output is a map of the WMA area showing regions where leaks would not be detected under the given site specific parameters provided as input to the model.

MEMO models are used as simple guides for determining network usefulness. A MEMO model for the WMA A-AX network with a southwest flow direction of 225 degrees provided a monitoring efficiency of $95.2 \%$ (Figure 4.1a). This was the flow direction for which the network was originally designed. Areas of the WMA shown in dark are where leaks can occur without detection by the currently used monitoring network. If the actual direction is south at 180 degrees, the monitoring efficiency drops to $82 \%$ (Figure 4.1b). For a flow direction to the southeast, at 125 degrees, the monitoring efficiency has dropped to $42.9 \%$ (Figure 4.1d). A direction of 90 degrees azimuth (east) results in an efficiency of $51 \%$. This means that currently $50 \%$ of the WMA is not being monitored if an eastern flow direction is correct.

With an east to southeast flow direction, the current network does not function adequately to provide coverage for WMA A-AX. Well 299-E25-2, an older non-RCRA well, is downgradient but lies between the 216-A-1 and the 216-A-7 cribs. The well location and the distance from the WMA make this well a poor choice for monitoring the WMA. Also this well is far from the required point of compliance. Furthermore, an easterly flow direction leaves the WMA without adequate upgradient coverage in the northern part to provide upgradient/downgradint comparisons.

Plans for developing and installing an improved network are given under monitoring issues below. The network development is proposed with verification of the flow direction using direct measurements of direction and rate within the opened screen interval of the borehole. Once direction and rate are verified, then a final design can be optimized using simple flow models. This approach will provide for complete coverage of the WMA even as the flow direction shifts back to pre-Hanford conditions.

\subsubsection{Dangerous Waste Constituents}

It is required under 40 CFR 265.94(a)(2) that WMA A-AX be monitored for indicator parameters (e.g., $\mathrm{pH}$, conductivity, total organic carbon [TOC], total organic halides [TOX]), that provide a reliable indication of the presence of dangerous constituents in groundwater. The constituents monitored at WMA A-AX were determined based on the:

- types and concentrations of constituents in the stored wastes

- mobility, stability and persistence of waste constituents in the unsaturated zone beneath WMA A-AX

- detectability of waste constituents in the groundwater

- concentrations or values of the monitoring parameters or constituents in the groundwater background chemistry. 

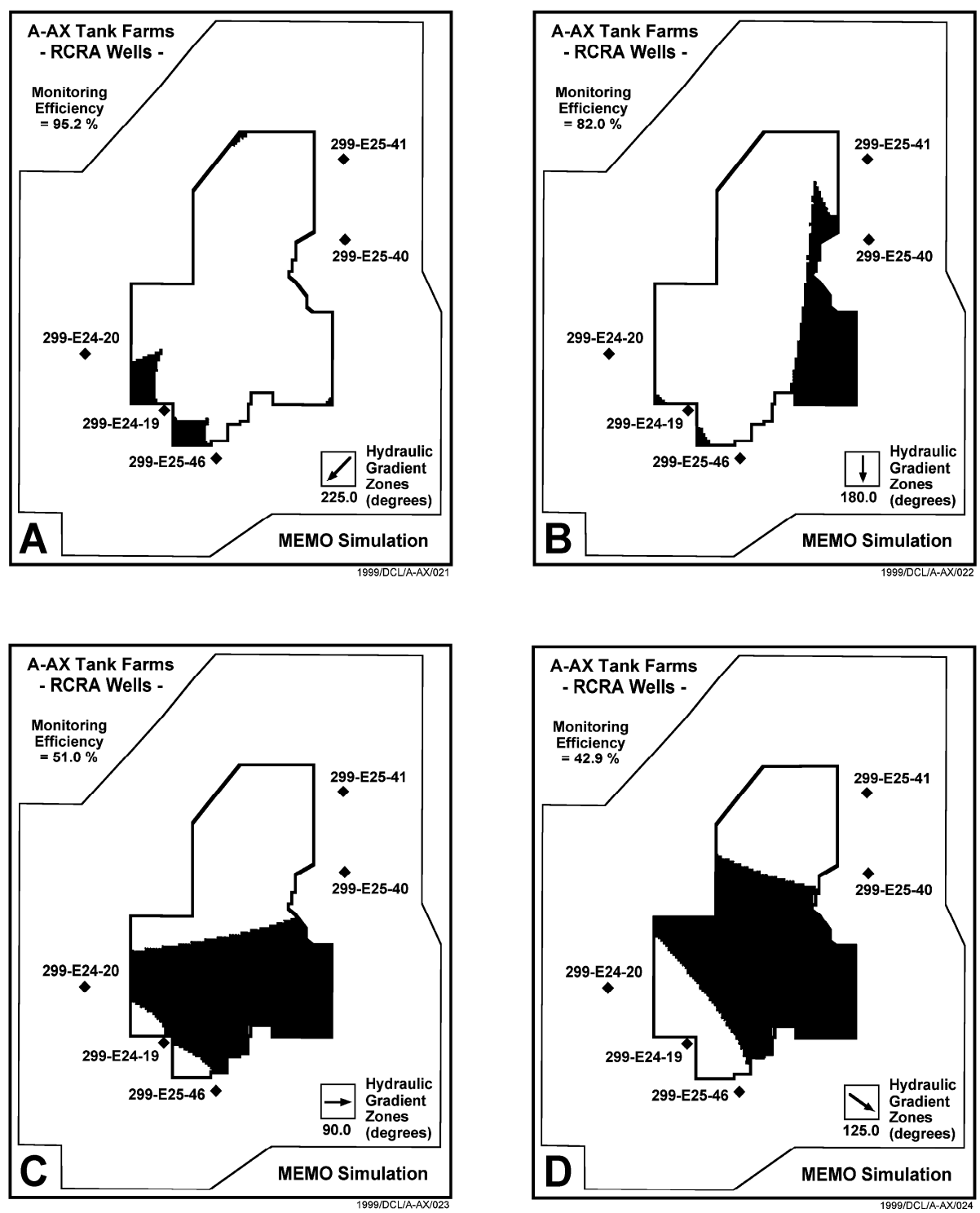

Figure 4.1. Series of MEMO Models Used to Evaluate Monitoring Efficiency at WMA A-AX. Black or shaded areas indicate those areas are not covered by the monitoring well network.

The site-specific sampling needs and issues at WMA A-AX are presented in the following section. The detailed sampling and analysis plan (SAP), consisting of the FSP and QAPP are provided in Appendix D.

\section{Groundwater Sampling Parameters}

According to 40 CFR 265.92 and by reference of WAC 173-303-400, the owner/operator of an interim-status hazardous waste facility must establish initial background concentrations for the contamination indicator parameters of conductivity, $\mathrm{pH}, \mathrm{TOC}$, and TOX. Four replicate analyses for each 
parameter from each well were obtained quarterly for 1 year. Statistical tests, as required, were applied to these data from upgradient wells to determine the initial background arithmetic mean and variance (40 CFR 265.93[b]). The critical means for WMA A-AX that resulted from these tests are presented in Table 4.2.

These initial background values will continue to be used until the monitoring network is updated with respect to the number and location of upgradient versus downgradient wells. Upon completion of the upgraded network, the required interim-status, detection sampling will be performed to allow calculation of new critical means for the indicator parameters.

The statistical method and calculations used to determine statistically significant increases in the concentration of indicator parameters of downgradent wells as compared to initial background concentrations, is the averaged replicate (AR) t-test, as presented in the Technical Enforcement Guidance Document (EPA 1986). Details of the statistical method can be found in Appendix D.

A table of indicator parameters along with site-specific constituents are presented in Table 4.3 in conformance with 40 CFR Part 265, Subpart F. Indicator parameters are evaluated semi-annually under the current monitoring system. The sampling frequency of each site-specific constituent is provided.

Table 4.2. Critical Mean Values for the WMA A-AX ${ }^{(a)}$

\begin{tabular}{|c|c|c|c|c|}
\hline Constituent, Unit & $\begin{array}{c}\text { Average } \\
\text { Background }\end{array}$ & $\begin{array}{l}\text { Standard } \\
\text { Deviation }\end{array}$ & Critical Mean & $\begin{array}{c}\text { Upgradient/ } \\
\text { Downgradient } \\
\text { Comparison } \\
\text { Value }\end{array}$ \\
\hline $\begin{array}{l}\text { Conductivity, } \\
\text { mhos/cm }\end{array}$ & 313.5 & 29.838 & 534.9 & 534.9 \\
\hline Field $\mathrm{pH}$ & 8.066 & 0.182 & {$[6.89,9.24]$} & {$[6.89,9.24]$} \\
\hline $\begin{array}{l}\text { Total Organic } \\
\text { Carbon, }{ }^{(b, c)} \mathrm{Tg} / \mathrm{L}\end{array}$ & 724.375 & 168.522 & $1,691.0$ & $1,691.0$ \\
\hline $\begin{array}{l}\text { Total Organic } \\
\text { Halides, }{ }^{(b, c)} \mathrm{Tg} / \mathrm{L}\end{array}$ & 2.552 & 0.791 & 7.1 & 17.9 \\
\hline \multicolumn{5}{|c|}{$\begin{array}{l}\text { (a) Data collected based on semiannual sampling events from February } 1998 \text { to June } 1999 \text { for } \\
\text { upgradient wells 299-E25-40 and 299-E25-41. } \\
\text { (b) Critical mean calculated from values reported below vendor's specified method of detection } \\
\text { limit. } \\
\text { (c) The upgradient/downgradient comparison value is the limit of quantitation (Hartman 1999), } \\
\text { calculated quarterly. }\end{array}$} \\
\hline
\end{tabular}


Table 4.3. Indicator Parameters and Site-Specific Waste Constituents Along with Sampling Frequency

\begin{tabular}{||c|c||}
\hline $\begin{array}{c}\text { Contaminant Indicator } \\
\text { Parameters }\end{array}$ & Sampling Frequency \\
\hline \hline $\mathrm{pH}$ & Semi-annual quadruplicates \\
\hline Conductivity & Semi-annual quadruplicates \\
\hline Total organic carbon & Semi-annual quadruplicates \\
\hline Total organic halides & Semi-annual quadruplicates \\
\hline \hline Site Specific Constituents & Sampling Frequency \\
\hline \hline Alkalinity & Semi-annual \\
\hline Anions & Semi-annual \\
\hline Low-level gamma scan & Semi-annual \\
\hline Gross alpha & Semi-annual \\
\hline Gross beta & Semi-annual \\
\hline Phenols & Annual \\
\hline ICP metals & Semi-Annual \\
\hline Technetium-99 & Semi-annual \\
\hline TDS & Semi-annual \\
\hline Uranium & Semi-annual \\
\hline Tritium & Semi-annual \\
\hline Iodine-129 & Annual \\
\hline Strontium-90 & Annual \\
\hline
\end{tabular}

The analysis for anions captures the values for nitrate, nitrite sulfate and chloride, which are the main mobile anionic species found in these tanks. The metals analysis provides concentrations for sodium, aluminum, calcium, iron, chromium, and potassium, the main mobile cations found in tank waste. The organics listed in tank waste with the greatest concentrations are glycolate, dibutyl phosphate (DBP), ethylenediaminetetraacetic acid (EDTA), N-(2-hydroxyethyl) ethylenediaminetetraacetic acid (HEDTA), and butanol. The analysis for TOC is performed in quadruplicates to monitor for these organics. The primary fission products are tritium, ${ }^{90} \mathrm{Sr},{ }^{90} \mathrm{Tc},{ }^{125} \mathrm{Sb}$, and ${ }^{137} \mathrm{Cs}$. Of these, tritium and ${ }^{99} \mathrm{Tc}$ are the most mobile species. Various uranium isotopes are monitored with a total uranium analysis.

Although some of the site-specific constituents appear to be relatively immobile, it is prudent to sample at least annually for detection, especially as surface operations change due to interim stabilization and waste removal operations. Also, ${ }^{90} \mathrm{Sr}$ has the greatest activity of the listed radionuclides in WMA A-AX SSTs (Appendix B). Although ${ }^{90} \mathrm{Sr}$ is not as mobile as ${ }^{99} \mathrm{Tc}$, it has been observed in groundwater at other sites, and consequently, is monitored annually. The WMA is located within a regional ${ }^{129}$ I plume. Although ${ }^{129} \mathrm{I}$ is not a major constituent in the tanks, it is analyzed annually because of its mobility in groundwater.

Recent observations at other SST sites indicate that sampling on a semi-annual frequency may not be adequate to detect short-lived pulses of waste from the tank farms (Narbutovskih 1998). MEMO monitoring efficiencies are based on continuous leak sources. If sudden releases occur as would be expected for a leaking line during limited waste transfers or from remobilized plumes due to water line 
ruptures, pulses of short duration may not be detected by the network since the wells are not close enough or monitored often enough for short duration contaminant events. This is because a plume from a pulse source would not be as dispersed as one for a continuous source. Consequently, these events may go unobserved with a semi-annual monitoring frequency and coarse well spacing. When the network has been reevaluated and the adequacy of downgradient coverage determined (and augmented, if needed), the sampling frequency for mobile constituents will be increased to at least quarterly.

\subsubsection{Monitoring Issues and Resolutions}

Monitoring issues specific to WMA A-AX have been identified in the above discussions of the groundwater monitoring plan. These issues are reiterated in this section for clarity along with solutions or tasks to solve monitoring problems. A tentative schedule for each task is also provided. The specific issues are as follows:

- The water table is essentially flat across the 200 East Area. Without an accurate measurement of the gradient, the flow direction across the WMA is questionable. Because the local flow can be quite different from the regional flow combined with changing flow directions as the B-Pond mound diminishes, regional water table contours and/or regional plume directions are unreliable for determining local flow across the site.

- Based on consistent water levels referenced to a more recent well elevation survey, the current flow direction may be to the east.

- The current network was designed for flow specifically to the southwest. Determination of this flow direction was based on a presumed regional flow due the presence of the B-Pond mound. No wells were placed to allow for changes in flow direction over time.

- Model studies using an east flow result in a monitoring efficiency of 51.0\%, suggesting contami nation entering the groundwater under half of the WMA is not detectable with the current location of wells.

- Recent revisions to the Part A Permit application for WMA A-AX have added the 244-AR Vault and farm ancillary equipment to the WMA. The vault is outside the boundary of either 241-A- or 241-AX Tank Farm. The approximate flow direction determined from current hydrographs indicates that well 299-E24-20 may not be placed adequately to detect groundwater contamination from this facility.

- Finally, with the present rate of water table decline, some wells in the network may be unusable in about six years.

A modified network might include as many as four new downgradient wells spaced approximately 200 to $250 \mathrm{ft}$ (65 to $82 \mathrm{~m}$ ) apart with up to three upgradient wells. More complete upgradient coverage is needed than the required one well at SST sites surrounded by liquid effluent disposal facilities to allow discriminating between tank waste and waste associated with these upgradient discharge facilities. The 
elongated geometry of the WMA boundaries also indicates the need for additional upgradient wells. These numbers are without respect to existing wells that may eventually become unusable due to the declining water levels. The design modifications to the existing network should account for current conditions and probable changes in flow direction to the southeast. Future well locations should also be chosen to allow differentiation, to the degree possible, between waste from surrounding DST waste storage/treatment/discharge facilities and waste from the SSTs. MEMO studies will be performed in support of network design after a more accurate flow direction is determined. Consideration will also be given at that time to coverage for the recent inclusion of the 244-AR-Vault into the WMA.

Because water levels are not accurate enough to determine flow direction, instruments such as the colloidal boroscope may be employed to verify and refine flow direction and rate. The colloidal boroscope is an in situ technique developed to directly measure the flow rate and direction through a borehole. It has been demonstrated successfully twice at the Hanford Site in FY 1994 and recently in FY 1999. It is also an accepted method of flow direction/rate used increasingly in the field of groundwater studies. Results of the Hanford tests indicate that the tool can provide useful, reliable information on flow properties in the highly transmissive Hanford formation sediments.

The list of specific tasks required to address monitoring issues at WMA A-AX are presented below along with a tentative schedule for preliminary tasks. A schedule for the installation of new wells will be incorporated into the plan with a change notice. Tasks are:

- confirm with Ecology specific objectives for monitoring at WMA A-AX FY 2001

- conduct investigation of degree to which monitoring well 299-E24-19 is not vertical using the downhole gyroscope

FY 2001

- determine flow direction and rate directly with the colloidal boroscope used in conjunction with refined water levels

2nd quarter, FY 2001

- perform flow modeling with correct flow rate/direction/point of compliance to obtain optimal well placement

3rd quarter FY 2001

- design network with well placement such that objectives are achieved; design to account for future flow directions

1st quarter FY 2002

- install wells

No tentative date. 
After an adequate well network is installed, the following changes in the groundwater plan will be made:

- Re-establish critical means for indicator parameters, specifically $\mathrm{pH}$ and conductivity, once upgradient wells have been installed.

- Determine groundwater flow rate and direction at new wells.

- Continue monitoring and investigate the cause of elevated chromium, nickel and manganese in well 299-E24-19. Evaluate the need for further investigation annually.

\subsubsection{Data Management, Interpretation, and Reporting}

The manner in which the data are received, handled and stored at Pacific Northwest National Laboratory (PNNL) is described in this section along with information pertaining to data interpretation and reporting of the project results to U.S. Department of Energy-RL (DOE-RL) and Washington State Department of Ecology (Ecology).

The contract laboratories provide analytical results in written report form and on digital disk. The results are then loaded into the Hanford Environmental Information System (HEIS) database. Fieldmeasured parameters such as field conductivity, $\mathrm{pH}$, temperature, and turbidity are entered manually or through electronic transfer from the sampling subcontractor. Data from HEIS can be downloaded to smaller databases, and spreadsheets for easier handling and interpretive analysis. The printed analytical data reports and original field records stored at PNNL are the official record copies. If questions arise concerning the validity of a data value, the official record copies are used for initial verification.

The data undergo a validation/verification process according to documented procedures as described in Appendix D.3 and according to the Hanford Groundwater Monitoring Project Quality Assurance Project Plan (QAPP). This plan is kept in project files at PNNL along with all documentation and data acquisition pertaining specifically to groundwater monitoring at WMA A-AX. As periodic reviews of the data are released, a copy of each review is kept in these project files. Beginning with FY 1996, the annual groundwater monitoring report contains a digital disk of all chemical and water level data collected for the year (Hartman 1999). The report is also accessible on the PNNL groundwater monitoring website at: http://hanford.pnl.gov/groundwater/gwmonrep.htm

Once the laboratory data are available on HEIS, a qualitative check is performed to assure that data are reasonable with respect to historic trends for each specific constituent of concern. If changes occur from one sampling interval to the next that are unusual, trend comparisons are made with an appropriate co-contaminant to verify the change. If the value continues to appear anomalous, the results are returned to the laboratory for further checking and possible reanalysis.

After data are validated and verified, the accepted data are used to interpret groundwater conditions at the site. Interpretive techniques include but are not limited to: 
- hydrographs: the water levels are plotted versus time to determine fluctuations in groundwater levels and any changes in flow direction.

- water-table maps: normally water-table elevations are mapped from multiple wells to construct contour maps to estimate flow directions. Groundwater flow is assumed to be perpendicular to lines of equal potential for the local region proximal to a WMA. In areas with a flat water table where contours can not be constructed with any certainty, flow direction must be estimated from relative well positions on hydrographs and/or from solutions to gradient fits using selected wells. The approximate gradient along with estimates of the saturated hydraulic conductivity and porosity are used to determine the flow rate. Data from the colloidal boroscope, however, will allow direct observation of the flow direction and provide an alternative method of estimating the local flow rate.

- historic trend plots: concentrations/activities of chemical and/or radiological constituents are plotted versus time to determine increases, decreases, and fluctuations in concentrations or activities. The trend plots are used to make upgradient/downgradient comparisons for indicator parameters. These plots may be used in tandem with hydrographs and/or water-table maps to determine if concentrations relate to changes in water-level or in groundwater flow directions.

- plume maps: distributions of chemical concentrations or radiological activities are mapped across the local WMA to determine the extent of contamination. Changes in plume distribution where noticeable movement occurs over time aid in determining movement of plumes and the direction of flow.

- contaminant ratios can also be used to distinguish between different sources of contamination.

- conductivity charge balances are used to check the quality of the data.

A summary of the reporting requirements for compliance with 40 CFR 265, Subpart F are listed in Table 4.4. 
Table 4.4. Reports Required for Compliance with 40 CFR 265, Subpart F, for Groundwater Monitoring

\begin{tabular}{|c|c|c|c|}
\hline Submittal & Submittal Period & Reporting Vehicle & $\begin{array}{c}\text { Regulatory } \\
\text { Requirement }\end{array}$ \\
\hline $\begin{array}{l}\text { First Year of Sampling: } \\
\text { Concentrations of Interim Primary } \\
\text { Drinking Water Constituents, } \\
\text { Identifying Those that Exceed Limits. }\end{array}$ & Q Quarterly & Complete $^{(\mathrm{a})}$ & $\begin{array}{l}40 \text { CFR } \\
265.94(a)(2)(\mathrm{i})\end{array}$ \\
\hline $\begin{array}{l}\text { Concentration and Statistical Analyses } \\
\text { of Groundwater Contamination } \\
\text { Indicator Parameters, Noting } \\
\text { Significant Differences in Upgradient } \\
\text { Wells. }\end{array}$ & $\begin{array}{l}\text { Annually, by } \\
\text { March } 1 \text { of following } \\
\text { year. }\end{array}$ & $\begin{array}{l}\text { Hanford } \\
\text { Groundwater } \\
\text { Monitoring Report } \\
\text { (e.g., Hartman 1999) }\end{array}$ & $\begin{array}{l}40 \text { CFR } \\
265.94(\mathrm{a})(2)(\mathrm{ii})\end{array}$ \\
\hline $\begin{array}{l}\text { Results of Groundwater Surface } \\
\text { Elevation Evaluation and Description } \\
\text { of Response if Appropriate. }\end{array}$ & $\begin{array}{l}\text { Annually, by } \\
\text { March } 1 \text { of following } \\
\text { year. }\end{array}$ & $\begin{array}{l}\text { Hanford } \\
\text { Groundwater } \\
\text { Monitoring Report }\end{array}$ & $\begin{array}{l}40 \text { CFR } \\
265.94(\mathrm{a})(2)(\mathrm{iii})\end{array}$ \\
\hline $\begin{array}{l}\text { Outline For Groundwater Quality } \\
\text { Assessment Program }\end{array}$ & $\begin{array}{l}\text { Within one year after } \\
\text { effective date of } \\
\text { regulations }\end{array}$ & $\begin{array}{l}\text { Appendix A of this } \\
\text { document }\end{array}$ & 40 CFR 265.93(a) \\
\hline $\begin{array}{l}\text { Notification of Statistical }^{(\mathrm{B})} \\
\text { Exceedance }^{(\mathrm{s})}\end{array}$ & $\begin{array}{l}\text { Within } 7 \text { days of } \\
\text { verification }\end{array}$ & Letter to Ecology & 40 CFR 265.93(c) \\
\hline Assessment Plan $^{(\mathrm{B})}$ & $\begin{array}{l}\text { Within } 15 \text { days of } \\
\text { notification }\end{array}$ & $\begin{array}{l}\text { PNNL document or } \\
\text { letter }\end{array}$ & 40 CFR 265.93(d) \\
\hline $\begin{array}{l}\text { Determinations Under Assessment } \\
\text { Program }^{(\mathrm{B})}\end{array}$ & $\begin{array}{l}\text { As soon as tech- } \\
\text { nically feasible; } \\
\text { annually thereafter }\end{array}$ & $\begin{array}{l}\text { PNNL document, } \\
\text { letter, or Hanford } \\
\text { Groundwater } \\
\text { Monitoring Report }\end{array}$ & $\begin{array}{l}40 \text { CFR 265.93(d)(5) } \\
\text { and 265.94(b) }\end{array}$ \\
\hline $\begin{array}{l}\text { (a) Requirement was fulfilled during } \\
\text { continues via HEIS. } \\
\text { (b) Required if exceedance occurs a }\end{array}$ & rified. & lished reports. & y submittal of data \\
\hline
\end{tabular}




\subsection{References}

10 CFR 962. Radioactive Waste: Byproduct Material. U.S. Code of Federal Regulations, as amended.

40 CFR 265. Interim Status Standards for Owners and Operators of Hazardous Waste Treatment Storage and Disposal Facilities. U.S. Code of Federal Regulations.

51 FR 24504, "State Authority to Regulate the Hazardous Components of Radioactive Mixed Wastes Under the Resource Conservation and Recovery Act." Federal Register, Vol. 51, No. 128, pp. 2450424505, (July 3).

Agnew, S. F. 1997. Hanford Tank Chemical and Radionuclide Inventories: HDW Model, Rev. 4. LA-UR-96-3860, Los Alamos National Laboratory, Los Alamos, New Mexico.

Allen, G. K. 1991. Tank 241-A-105 Evaporation Estimate 1970 through 1978. WHC-EP-0410, Westinghouse Hanford Company, Richland, Washington.

Anderson, J. D. 1990. A History of the 200 Area Tank Farms. WHC-MR-0132, Westinghouse Hanford Company, Richland, Washington.

Bjornstad, B. N., K. R. Fecht, and A. M. Tallman. 1987. Quaternary Geology of the Pasco Basin, Washington. RHO-BW-SA-563A, Rockwell Hanford Operations, Richland, Washington.

Caggiano, J. A. 1991. Fate and Transport of Constituents Leaked from Tank 241-A-105. WHC-EP0412, Westinghouse Hanford Company, Richland, Washington.

Caggiano, J. A., and S. M. Goodwin. 1991. Interim-Status Groundwater Monitoring Plan for the Single Shell Tanks. WHC-SD-EN-AP-012, Rev. 1, Westinghouse Hanford Company, Richland, Washington.

Connelly, M. P., J. V. Borghese, C. D. Delaney, B. H. Ford, J. W. Lindberg, and S. J. Trent. 1992. Hydrogeologic Model for the 200 East Groundwater Aggregate Area. WHC-SD-EN-TI-019, Westinghouse Hanford Company, Richland, Washington.

Delaney, C. D., K. A. Lindsey, and S. P. Reidel. 1991. Geology and Hydrology of the Hanford Site: A Standardized Text for Use in Westinghouse Hanford Company Documents and Reports. WHC-SC-ERTI-003, Westinghouse Hanford Company, Richland, Washington.

Demenico, P. A., and G. A. Robbins. 1985. "A New Method of Contaminant Plume Analysis." Groundwater Vol. 23, No. 4.

Golder Associates, Inc. 1990. Low Level Waste Burial Grounds, RCRA Part B Permit Application, Section 5: Groundwater Monitoring. Redmond, Washington. 
Hanlon, B. M. 1999. Waste Tank Summary Report for Month Ending February 28, 1999. HNF-EP0182-131, Fluor Daniel Hanford, Inc., Richland, Washington.

Hartman, M. J., ed. 1999. Hanford Site Groundwater Monitoring for Fiscal Year 1998. PNNL-12086, Pacific Northwest National Laboratory, Richland, Washington.

Hartman, M. J., ed. 2000. Hanford Site Groundwater Monitoring for Fiscal Year 1998. PNNL-13116, Pacific Northwest National Laboratory, Richland, Washington.

Hartman, M. J., and P. E. Dresel. 1997. Hanford Site Groundwater Monitoring for Fiscal Year 1998. PNNL-11470, Pacific Northwest National Laboratory, Richland, Washington.

Hodges, F. N. 1998. Results of Phase I Groundwater Quality Assessment for Single-Shell Tank Waste Management Areas T and T-TX at the Hanford Site. PNNL-11809-UC-502, Pacific Northwest National Laboratory, Richland, Washington.

Jansen, G., Jr., W. E. Willingham, and W. V. Demier. 1965. Techniques for Calculating Tank Temperatures and Soil Temperatures Near Leaks-Application to PUREX Waste Tank 105A. BNWL0CC-376, Pacific Northwest Laboratory, Richland, Washington.

Jensen, E. J., S. P. Airhart, M. A. Chamness, T. J Gilmore, D. R. Newcomer, and K. R. Oster. 1989. Interim-Status Ground-Water Monitoring Plan for the Single-Shell Tanks. WHC-SD-EN-AP-012, Rev. 0, Westinghouse Hanford.

Johnson, V. G., and C. J. Chou. 1998. Results of Phase I Groundwater Quality Assessment for Single-Shell Tank Waste Management Areas S-SX at the Hanford Site. PNNL-11810-UC-502, Pacific Northwest National Laboratory, Richland, Washington.

Johnson, V. G. 1993. Operational Groundwater Status Report, 1990-1992. WHC-EP-0595, Westinghouse Hanford Company, Richland, Washington.

Jones, T. E., R. Khaleel, D. A. Myers, J. W. Shade, M. I. Wood. 1998. A Summary and Evaluation of Hanford Site Tank Farm Subsurface Contamination. HNF-2603, Rev. 0, Lockheed Martin Hanford, Richland, Washington.

Kupfer, M. J., A. L. Boldt, B. A. Higley, K. M. Hodgson, L. W. Shelton, B. C. Simpson, R. A. Watrous, M. D. LeClair, G. L. Borsheim, R. T. Winward, R. M. Orme, N. G. Colton, S. L. Lambert, D. E. Place and W. W. Schulz. 1997. Standard Inventories of Chemicals and Radionuclides in Hanford Site Tank Wastes. HNF-SD-WM-TI-740, Fluor Daniel Hanford, Inc., Richland, Washington.

Lindsey, K. A. 1996. The Miocene to Pliocene Ringold Formation and Associated Deposits of the Ancestral Columbia River System, South-central Washington and North-central Oregon. Open File Report 96-8, Washington State Department of Natural Resources, Olympia, Washington. 
Lindsey, K. A. 1992. Geologic Setting of the 200 East Area; An Update. WHC-SD-EN-TI-012, Rev. 0, Westinghouse Hanford Company, Richland, Washington.

Lindsey, K. A., and K. D. Reynolds. 1998. Geology and Stratigraphy of the Tank Farms. In T. E. Jones, R. Khaleel, D. A. Myers, J. W. Shade, and M. I. Wood. 1998. A Summary and Evaluation of Hanford Site Tank Farm Subsurface Contamination. HNF-2603, Rev. 0, Lockheed Martin Hanford, Richland, Washington.

Lindsey, K. A., B. N. Bjornstad, J. W. Lindberg, and K. M. Hoffman. 1992. Geologic Setting of the 200 East Area: An Update. WHC-SD-EN-TI-012, Rev. 0, Westinghouse Hanford Company, Richland, Washington.

McKee, E. H., D. A. Swanson, and T. L. Wright. 1977. "Duration and Volume of Columbia River Basalt Volcanism, Washington, Oregon, and Idaho." Geological Society of America Abstracts with Programs, Vol. 9, pp. 463-464.

Myers, D. A., D. L. Parker, R. J. Serne, G. V. Last, V. G. Johnson, G. W. Gee, and D. J. Moak. 1998. Findings of the Extension of Borehole 41 -09-39, 241-SX Tank Farm. HNF-2855, Rev. 0, Lockheed Martin Hanford Corporation, Richland, Washington.

Myers, C. W., and S. M. Price. 1979. Geologic Studies of the Columbia Plateau-A Status Report. RHO-BWI-ST 4, Rockwell Hanford Operations, Richland, Washington.

Narbutovskih, S. M. 1998. Results of Phase I Groundwater Quality Assessment for Single-Shell Tank Waste Management Areas B-BX-BY at the Hanford Site. PNNL-11826-UC-502, Pacific Northwest National Laboratory, Richland, Washington.

Narbutovskih, S. M, D. F. Iwatate, M. D. Sweeney, A. L. Ramirez, W. Daily, R. M. Morey, and L. Christensen. 1996. Feasibility of CPT-Deployed Vertical Electrode Array in Single-Shell Tank Farms. WHC-SD-EN-TA-004, Rev. 0, Westinghouse Hanford Company, Richland, Washington.

PNNL. 1998. The Hanford Ground-Water Monitoring Project Quality Assurance Project Plan, QA Plan ETD-012, Rev. 1, Pacific Northwest National Laboratory, Richland, Washington.

Price, W. H., and K. R. Fecht. 1976a. Geology of the 241-A Tank Farm. ARH-LD-127, Atlantic Richfield Hanford Company, Richland, Washington.

Price, W. H., and K. R. Fecht. 1976b. Geology of the 241-AX Tank Farm. ARH-LD-128, Atlantic Richfield Hanford Company, Richland, Washington.

Reidel, S. P., and K. R. Fecht. 1994. Geologic Map of the Richland 1:100,000 Quadrangle, Washington. Open File Report 94-8, Washington State Department of Natural Resources, Olympia, Washington. Stephens, D. B. 1996. "Vadose Zone Hydrology." Lewis Publishers, CRC Press, Inc., Boca Ration, Florida. 
Serne, R. J., J. M. Zachara, and D. S. Burke. 1998. Chemical Information on Tank Supernatants, Cs Adsorption from Tank Liquids Onto Hanford Sediments, and Field Observations of Cs from Past Tank Leaks. PNNL-11495, Pacific Northwest National Laboratory, Richland, Washington.

Stephens, D. B. 1997. Vadose Zone Hydrogeology. CRC Press, Inc., Boca Raton, Florida.

Tallman, A. M., K. R. Fecht, M. C. Marratt, and G. V. Last. 1979. Geology of the Separation Areas, Hanford Site, South-Central Washington. RHO-ST-23, Rockwell Hanford Operations, Richland, Washington.

Thorne, P. D., and D. R. Newcomer. 1992. Summary and Evaluation of Available Hydraulic Property Data for the Hanford Site Unconfined Aquifer System. PNL-8337-UC-402, 403, Pacific Northwest National Laboratory, Richland, Washington.

Trent, S. J. 1992. Unconfined Aquifer Hydrologic Test Data Package for the 200 East Groundwater Aggregate Area Management Study. WHC-SD-EN-DP-030, Rev. 0, Westinghouse Hanford Company, Richland, Washington.

U.S. Department of Energy (DOE). 1998. Tank Summary Data Report for Tank A-103. DOE/GJ-HAN108, Grand Junction Office, Grand Junction, Colorado.

U.S. Department of Energy (DOE). 1998. Tank Summary Data Report for Tank A-104, DOE/GJ-HAN109, Grand Junction Office, Grand Junction, Colorado.

U.S. Department of Energy (DOE). 1998. Tank Summary Data Report for Tank A-105. DOE/GJ-HAN110, Grand Junction Office, Grand Junction, Colorado.

U.S. Department of Energy (DOE). 1998. Tank Summary Data Report for Tank A-106. DOE/GJ-HAN111, Grand Junction Office, Grand Junction, Colorado.

U.S. Department of Energy (DOE). 1997. AX Tank Farm Report. DOE/GJO-HAN-12, Grand Junction Office, Grand Junction, Colorado.

U.S. Department of Energy (DOE). 1996. Dangerous Waste Permit Application; Single-Shell Tank System. DOE/RL-88-21, Rev. 4, Richland, Washington.

U.S. Department of Energy (DOE). 1996. Single-Shell Tank Closure Work Plan. DOE/RL-89-16, Rev. 1, Richland, Washington.

U.S. Department of Energy (DOE). 1993. B Plant Source Aggregate Area Management Study Report (AAMSR). DOE/RL-92-05, Richland, Washington.

U.S. Department of Energy (DOE). 1993. PUREX Source Aggregate Area Management Study Report (AAMSR). DOE/RL-92-04, Richland, Washington. 
U.S. Department of Energy (DOE). 1988. Consultation Draft, Site Characterization Plan, Reference Repository Location, Hanford Site, Washington. DOE/RW-0164, Washington D.C.

U.S. Environmental Protection Agency (EPA). 1986. RCRA Groundwater Monitoring Technical Enforcement Guidance Document. Washington, D.C.

Washington State Administrative Code (WAC). Minimum Standards for Construction and Maintenance of Wells, WAC 173-160, Olympia, Washington (as amended).

Washington State Administrative Code (WAC). Dangerous Waste Regulations. WAC 173-303, Olympia, Washington (as amended).

Washington State Department of Ecology (Ecology). 1994. Dangerous Waste Portion of the Resource Conservation and Recovery Act Permit for the Treatment, Storage, and Disposal of Dangerous Waste. Permit Number WA7890008967.

Westinghouse Hanford Company (WHC). 1991. Tank 241-A-105 Leak Assessment, WHC-MR-0264, Westinghouse Hanford Company, Richland, Washington.

Williams, B. A., B. N. Bjornstad, R. Schalla, W. D. Webber. 2000. Revised Hydrogeology for the Suprabasalt Aquifer System, 200-East Area and Vicinity, Hanford Site, Washington. PNNL-12261, Pacific Northwest Laboratory, Richland, Washington.

Wilson, C. R., C. M. Einberger, R. L. Jackson, R. B. Mercer. 1993. Design of Ground-water Monitoring Networks Using the Monitoring Efficiency Model (MEMO). Ground Water 30(6) 965-970.

Wurstner, S. K., P. D. Thorne, M. A. Chamness, M. D. Freshley, M. D. Williams. 1995. Development of a Three-Dimensional Ground-Water Model of the Hanford Site Unconfined Aquifer System: FY 1995 Status Report. PNL-10886. Pacific Northwest National Laboratory, Richland, Washington. 


\section{Appendix A}

\section{Tank Waste Inventory}




\section{Appendix A}

\section{Tank Waste Inventory}

The wastes received by the 241-A and 241-AX Tank Farms were alkaline slurries of mixed waste, containing dangerous constituents and radioactive fission products. Although only the dangerous and extremely hazardous wastes, as defined by WAC 173-303 are regulated under RCRA monitoring programs, analyses of groundwater samples are performed to also detect the radioactive components. The combination of monitoring for both components of the mixed waste increases the ability to detect waste associated specifically with WMA A-AX. As such, the waste inventory is provided in this appendix on a tank-by-tank basis and includes description of both hazardous and radioactive species.

These data are taken from Agnew (1997) based on the Hanford Defined Waste Model. This model estimates the whole tank inventory based on process knowledge and accounting for nuclear decay and resulting daughter products. The tank-by-tank inventories include 26 chemical constituents and 46 radionuclides. The results shown include the total of the solid and liquid fractions for each tank in WMA A-AX. For a further description of the process by which these data are determined, the reader is referred to Agnew (1997).

In an attempt to resolve the inconsistencies between the currently used River Protection Project inventories and the Hanford Defined Waste Model developed by Los Alamos National Laboratory, the best-basis inventory was developed on both a global basis and a tank-by-tank basis for each of the 177 single - and double-shell tanks. This data set was not included at this time because results are present in total curies and not as concentrations, which are needed to compare to groundwater analytical results. The best basis data will, however, be consulted for relative differences between species in a given tank. The best basis data inventory is maintained by the River Projection Project as part of the Standard Inventory task and further description can found in Kupfer et al. 1997. 
HDW Model Rev. 4

\begin{tabular}{|c|c|c|c|c|c|c|c|}
\hline \multicolumn{8}{|c|}{ Single-Shell Tank 241-A-101 } \\
\hline & \multicolumn{7}{|c|}{ Tatal Inventory Estimate* } \\
\hline $\begin{array}{l}\text { Physical } \\
\text { Pronerties }\end{array}$ & & & & $.95 \mathrm{CI}$ & $-67 \mathrm{CI}$ & $+67 \mathrm{CI}$ & $+95 \mathrm{CI}$ \\
\hline Total Waste & $537 \mathrm{~F}+06 \mathrm{dos}$ & $(053 \mathrm{kgall}$ & & & & & \\
\hline Heat Load & $729 \mathrm{~kW}$ & $0249 \mathrm{E}+04 \mathrm{BTU} / \mathrm{hr}$ & & 6.66 & 7.03 & 7.53 & 788 \\
\hline Bulk Density $\dagger$ & $1.49(\mathrm{~g} / \mathrm{cc})$ & & & 144 & 147 & 1.50 & 1.51 \\
\hline Water wt $\%$ † & 42.3 & ... & & 401 & 408 & 436 & 154 \\
\hline TOC wt $\% \mathrm{C}$ (wet)t & 1.19 & & & 0664 & 020 & $\begin{array}{ll}420 \\
145\end{array}$ & 424 \\
\hline $\begin{array}{c}\text { Chemical } \\
\text { Constituents }\end{array}$ & mole/L & nnm & $\mathrm{kg}$ & $\begin{array}{c}-95 \mathrm{CI} \\
(\mathrm{mole} / \mathrm{L})\end{array}$ & $\begin{array}{c}-67 \mathrm{CI} \\
(\mathrm{mole} / \mathrm{L})\end{array}$ & $\begin{array}{c}+67 \mathrm{CI} \\
(\mathrm{mole} / \mathrm{L})\end{array}$ & $\begin{array}{c}+95 \mathrm{CI} \\
(\mathrm{mole} / \mathrm{L})\end{array}$ \\
\hline $\mathrm{Na}+$ & 11.2 & $1.73 \mathrm{E}+05$ & $9.27 \mathrm{E}+05$ & 102 & 107 & 116 & 119 \\
\hline $\mathrm{A} 13+$ & 1.39 & $2.53 \mathrm{E}+04$ & $1.36 \mathrm{E}+05$ & 117 & 134 & 143 & 147 \\
\hline $\mathrm{Fe} 3+($ total $\mathrm{Fe})$ & $1.60 \mathrm{E}-02$ & 601 & $3.23 \mathrm{E}+03$ & $149 \mathrm{E}-02$ & $1.55 \mathrm{E}-02$ & $166 \mathrm{E}-02$ & 1 - $11 \mathrm{E}-02$ \\
\hline $\mathrm{Cr} 3+$ & $9.83 \mathrm{E}-02$ & $3.43 \mathrm{E}+03$ & $1.84 \mathrm{E}+04$ & $869 \mathrm{E}-02$ & $930 \mathrm{E}-02$ & 0.103 & 0109 \\
\hline $\mathrm{Bi} 3+$ & $1.02 \mathrm{E}-03$ & 143 & 767 & $058 \mathrm{E}-04$ & 9 897E-04 & $105 \mathrm{E}_{-03}$ & $0 \mathrm{E}-03$ \\
\hline $\mathrm{La} 3+$ & $1.95 \mathrm{E}-05$ & 1.82 & 9.78 & $144 \mathrm{E}-05$ & $169 \mathrm{E}-05$ & $222 \mathrm{E}-05$ & $2.47 \mathrm{E}-05$ \\
\hline $\mathrm{Hg} 2+$ & $8.12 \mathrm{E}-06$ & 1.09 & 5.88 & 7 79E- 06 & 795E-06 & $8.29 \mathrm{E}-06$ & $8.46 \mathrm{E}-06$ \\
\hline $\mathrm{Zr}$ (as $\mathrm{ZrO}(\mathrm{OH}) 2$ ) & $1.29 \mathrm{E}-04$ & 7.88 & 42.3 & $1.19 \mathrm{E}-04$ & $1.22 \mathrm{E}-04$ & $1.33 \mathrm{E}-04$ & $1.38 \mathrm{E}-04$ \\
\hline $\mathrm{Pb} 2+$ & $1.09 \mathrm{E}-03$ & 152 & 817 & $8.49 \mathrm{E}-04$ & $268 \mathrm{E}-04$ & $122 \mathrm{E}-03$ & $134 \mathrm{E}-03$ \\
\hline $\mathrm{Ni} 2+$ & $4.62 \mathrm{E}-03$ & 182 & 978 & $4.34 \mathrm{E}-03$ & $4.53 \mathrm{E}-03$ & $4.67 \mathrm{E}-03$ & $4.71 \mathrm{E}-03$ \\
\hline $\mathrm{Sr} 2+$ & 0 & 0 & 0 & 0 & 0 & & 0 \\
\hline $\mathrm{Mn} 4+$ & $3.76 \mathrm{E}-03$ & 139 & 746 & $323 \mathrm{E}-03$ & $3.49 \mathrm{E}-03$ & $4.03 \mathrm{E}-03$ & $4.29 \mathrm{E}-03$ \\
\hline $\mathrm{Ca} 2+$ & $2.47 \mathrm{E}-02$ & 666 & $3.58 \mathrm{E}+03$ & $232 \mathrm{E}-02$ & $239 \mathrm{E}-02$ & $255 \mathrm{E}-02$ & $263 \mathrm{E}-02$ \\
\hline $\mathrm{K}+$ & $5.37 \mathrm{E}-02$ & $1.41 \mathrm{E}+03$ & $7.58 \mathrm{E}+03$ & $4.62 \mathrm{E}-02$ & $494 \mathrm{E}-02$ & $588 \mathrm{E}-02$ & $6.56 \mathrm{E}-02$ \\
\hline $\mathrm{OH}-$ & 7.88 & $9.00 \mathrm{E}+04$ & $4.83 \mathrm{E}+05$ & 6.80 & 7.58 & 8.07 & 8.22 \\
\hline $\mathrm{NO} 3-$ & 3.57 & $1.49 \mathrm{E}+05$ & $7.98 \mathrm{E}+05$ & 330 & 348 & 366 & 375 \\
\hline $\mathrm{NO} 2-$ & 2.04 & $6.30 \mathrm{E}+04$ & $3.38 \mathrm{E}+05$ & 164 & 181 & 229 & 2.35 \\
\hline $\mathrm{CO} 32-$ & 0.422 & $1.70 \mathrm{E}+04$ & $9.13 \mathrm{E}+04$ & 0.389 & 0.405 & 0.439 & 0.450 \\
\hline $\mathrm{PO} 43-$ & $7.66 \mathrm{E}-02$ & $4.88 \mathrm{E}+03$ & $2.62 \mathrm{E}+04$ & $665 \mathrm{E}-02$ & $7095-02$ & $11 \mathrm{E}-02$ & 20E_-02 \\
\hline SO42- & 0.234 & $1.51 \mathrm{E}+04$ & $8.11 \mathrm{E}+04$ & 0.188 & 0.207 & 0.266 & 0.268 \\
\hline $\mathrm{Si}$ (as $\mathrm{SiO} 32-)$ & $6.45 \mathrm{E}-02$ & $1.22 \mathrm{E}+03$ & $6.53 \mathrm{E}+03$ & $5.69 \mathrm{E}-02$ & $606 \mathrm{E}-02$ & $6.83 \mathrm{E}-02$ & $721 \mathrm{E}-02$ \\
\hline $\mathrm{F}-$ & $5.51 \mathrm{E}-02$ & 704 & $3.78 \mathrm{E}+03$ & $4.72 \mathrm{E}-02$ & $5.05 \mathrm{E}-02$ & $6.03 \mathrm{E}-02$ & $6.81 \mathrm{E}-02$ \\
\hline $\mathrm{Cl}-$ & 0.194 & $4.61 \mathrm{E}+03$ & $2.47 \mathrm{E}+04$ & 0.167 & 0.179 & 0.200 & 0.205 \\
\hline C6H5O73- & $2.72 \mathrm{E}-02$ & $3.45 \mathrm{E}+03$ & $1.85 \mathrm{E}+04$ & $249 \mathrm{E}-02$ & $258 \mathrm{E}-02$ & $286 \mathrm{E}-02$ & $308 \mathrm{E}-02$ \\
\hline EDTA4- & $2.86 \mathrm{E}-02$ & $5.53 \mathrm{E}+03$ & $2.97 \mathrm{E}+04$ & $924 \mathrm{E}-03$ & $1.87 \mathrm{E}-02$ & $386 \mathrm{E}-02$ & $4.83 \mathrm{E}-02$ \\
\hline HEDTA3- & $5.14 \mathrm{E}-02$ & $9.46 \mathrm{E}+03$ & $5.08 \mathrm{E}+04$ & $127 \mathrm{E}-02$ & $316 \mathrm{E}-02$ & $7.13 \mathrm{E}-02$ & $208 \mathrm{E}-02$ \\
\hline glycolate- & 0.106 & $5.35 \mathrm{E}+03$ & $2.87 \mathrm{E}+04$ & $675 \mathrm{E}-02$ & $864 \mathrm{E}-02$ & 0126 & 0.146 \\
\hline acetate- & $1.86 \mathrm{E}-02$ & 737 & $3.96 \mathrm{E}+03$ & $1.48 \mathrm{E}-02$ & $164 \mathrm{E}-02$ & $2.09 \mathrm{E}-02$ & $2.45 \mathrm{E}-02$ \\
\hline oxalate2- & $2.56 \mathrm{E}-05$ & 1.51 & 8.12 & $228 \mathrm{E}-05$ & $242 \mathrm{E}-05$ & $270 E_{-05}$ & $284 \mathrm{E}-05$ \\
\hline DBP & $2.17 \mathrm{E}-02$ & $3.06 \mathrm{E}+03$ & $1.65 \mathrm{E}+04$ & $1.81 \mathrm{E}-02$ & 1 197E-02 & $2.39 \mathrm{E}-02$ & $271 \mathrm{E}-02$ \\
\hline butanol & $2.17 \mathrm{E}-02$ & $1.08 \mathrm{E}+03$ & $5.80 \mathrm{E}+03$ & $1.81 \mathrm{E}-02$ & $197 \mathrm{E}-02$ & $239 \mathrm{E}-02$ & $271 \mathrm{E}-02$ \\
\hline $\mathrm{NH} 3$ & $5.06 \mathrm{E}-02$ & 578 & $3.10 \mathrm{E}+03$ & $420 \mathrm{E}-02$ & $4.54 \mathrm{E}-02$ & $572 \mathrm{E}-02$ & $6.49 \mathrm{E}-02$ \\
\hline $\mathrm{Fe}(\mathrm{CN}) 64-$ & 0 & 0 & 0 & 0 & 0 & 0 & \\
\hline
\end{tabular}

*Unknowns in tank solids inventory are assigned by Tank Layering Model (TLM).

$\dagger$ Water wt $\%$ derived from the difference of density and total dissolved species. 
HDW Model Rev. 4

\begin{tabular}{|c|c|c|c|c|c|c|c|}
\hline & \multicolumn{7}{|c|}{ Single-Shell Tank 241-A-101 } \\
\hline & \multicolumn{7}{|c|}{ Total Inventory Estimate* } \\
\hline Phvsical Pronerties & & & & $.05 \mathrm{CI}$ & $.67 \mathrm{CI}$ & $+67 \mathrm{CI}$ & $+95 \mathrm{CI}$ \\
\hline Total Waste & $5.37 \mathrm{E}+06(\mathrm{~kg})$ & $(953 \mathrm{kgal})$ & -- & --- & $-\cdots$ & $-\ldots$ & $\ldots$ \\
\hline Heat Load & $7.29(\mathrm{~kW})$ & $(2.49 \mathrm{E}+04 \mathrm{BTU} / \mathrm{hr})$ & --- & 6.66 & 7.03 & 7.53 & 7.88 \\
\hline Bulk Density & $1.49(\mathrm{~g} / \mathrm{cc})$ & $\ldots$ & $\ldots$ & 1.44 & 1.47 & 1.50 & 1.51 \\
\hline Water wt $\% \dagger$ & 42.3 & -- & --- & 40.1 & 40.8 & 43.6 & 45.4 \\
\hline TOC wt\% C (wet) $\dagger$ & 1.19 & --- & ---- & 0.664 & 0.921 & 1.45 & 1.71 \\
\hline $\begin{array}{l}\text { Radiological } \\
\text { Constituents }\end{array}$ & Cill & |Ci/a & $\mathrm{Ci}$ & $.05 \mathrm{CL}(\mathrm{Ci} / \mathrm{L})$ & 67CL(Ci/L) & $\pm 67 \mathrm{CL}(\mathrm{Ci} / \mathrm{L})$ & \pm 05 CL $(\mathrm{Ci} / \mathrm{L} / \mathrm{L}$ \\
\hline $\mathrm{H}-3$ & $2.03 \mathrm{E}-04$ & 0.136 & 731 & $1.35 \mathrm{E}-04$ & 1.35E-04 & $2.18 \mathrm{E}-04$ & $2.37 \mathrm{E}-04$ \\
\hline $\mathrm{C}-14$ & $3.18 \mathrm{E}-05$ & $2.14 \mathrm{E}-02$ & 115 & $1.76 \mathrm{E}-05$ & $1.76 \mathrm{E}-05$ & $3.24 \mathrm{E}-05$ & $3.29 \mathrm{E}-05$ \\
\hline $\mathrm{Ni}-59$ & $1.99 \mathrm{E}-06$ & $1.33 \mathrm{E}-03$ & 7.16 & $1.32 \mathrm{E}-06$ & $1.32 \mathrm{E}-06$ & $2.04 \mathrm{E}-06$ & $2.08 \mathrm{E}-06$ \\
\hline $\mathrm{Ni}-63$ & $1.95 \mathrm{E}-04$ & 0.131 & 703 & $1.29 \mathrm{E}-04$ & $1.29 \mathrm{E}-04$ & $2.00 \mathrm{E}-04$ & $2.04 \mathrm{E}-04$ \\
\hline $\mathrm{C}_{0}-60$ & $4.02 \mathrm{E}-05$ & $2.70 \mathrm{E}-02$ & 145 & $2.40 \mathrm{E}-05$ & $2.40 \mathrm{E}-05$ & 4.13E-05 & 4.24E- -05 \\
\hline $\mathrm{Se}-79$ & $3.29 \mathrm{E}-06$ & $2.21 \mathrm{E}-03$ & 11.9 & $2.39 \mathrm{E}-06$ & $2.39 \mathrm{E}-06$ & $3.62 \mathrm{E}-06$ & 3.93E-06 \\
\hline Sr-90 & 0.133 & 89.5 & $4.81 \mathrm{E}+05$ & 0.126 & 0.131 & 0.136 & 0.138 \\
\hline Y-90 & 0.133 & 89.6 & $4.81 \mathrm{E}+05$ & 0.102 & 0.102 & 0.136 & 0.138 \\
\hline Zr-93 & $1.61 \mathrm{E}-05$ & $1.08 \mathrm{E}-02$ & 58.1 & $1.16 \mathrm{E}-05$ & $1.16 \mathrm{E}-05$ & $1.77 \mathrm{E}-05$ & $1.93 \mathrm{E}-05$ \\
\hline $\mathrm{Nb}-93 \mathrm{~m}$ & $1.17 \mathrm{E}-05$ & $7.87 \mathrm{E}-03$ & 42.3 & $8.55 \mathrm{E}-06$ & $8.55 \mathrm{E}-06$ & $1.29 \mathrm{E}-05$ & $1.40 \mathrm{E}-05$ \\
\hline Tc-99 & $2.41 \mathrm{E}-04$ & 0.162 & 869 & $1.88 \mathrm{E}-04$ & $2.14 \mathrm{E}-04$ & $2.71 \mathrm{E}-04$ & $3.12 \mathrm{E}-04$ \\
\hline Ru-106 & 7.09E-09 & $4.76 \mathrm{E}-06$ & $2.56 \mathrm{E}-02$ & $4.99 \mathrm{E}-09$ & $4.99 \mathrm{E}-09$ & $7.69 \mathrm{E}-09$ & $8.27 \mathrm{E}-09$ \\
\hline $\mathrm{Cd}-113 \mathrm{~m}$ & $8.53 \mathrm{E}-05$ & $5.73 \mathrm{E}-02$ & 308 & $5.82 \mathrm{E}-05$ & $5.82 \mathrm{E}-05$ & $9.52 \mathrm{E}-05$ & $1.05 \mathrm{E}-04$ \\
\hline $\mathrm{Sh}-125$ & $1.80 \mathrm{E}-04$ & 0.121 & 651 & $1.10 \mathrm{E}-04$ & $1.10 \mathrm{E}-04$ & $1.87 \mathrm{E}-04$ & $1.93 \mathrm{E}-04$ \\
\hline Sn-126 & $4.98 \mathrm{E}-06$ & $3.35 \mathrm{E}-03$ & 18.0 & $3.63 \mathrm{E}-06$ & $3.63 \mathrm{E}-06$ & $5.47 \mathrm{E}-06$ & 5.95E-06 \\
\hline $\mathrm{L}-129$ & $4.65 \mathrm{E}-07$ & $3.13 \mathrm{E}-04$ & 1.68 & 3.63E-07 & 4.13E- 07 & $5.24 \mathrm{E}-07$ & 6.03E-07 \\
\hline Cs-134 & $3.50 \mathrm{E}-06$ & $2.35 \mathrm{E}-03$ & 12.6 & $2.03 \mathrm{E}-06$ & $2.75 \mathrm{E}-06$ & $4.25 \mathrm{E}-06$ & 4.99E-06 \\
\hline Cs-137 & 0.240 & 161 & $8.66 \mathrm{E}+05$ & 0.213 & 0.225 & 0.254 & 0.274 \\
\hline Ba- $137 m$ & 0.227 & 152 & $8.19 \mathrm{E}+05$ & 0.188 & 0.188 & 0.240 & 0.253 \\
\hline Sm-151 & $1.16 \mathrm{E}-02$ & 7.79 & $4.19 \mathrm{E}+04$ & $8.44 \mathrm{E}-03$ & $8.44 \mathrm{E}-03$ & $1.28 \mathrm{E}-02$ & $1.38 \mathrm{E}-02$ \\
\hline Eu-152 & $4.46 \mathrm{E}-06$ & $2.99 \mathrm{E}-03$ & 16.1 & $3.34 \mathrm{E}-06$ & $3.34 \mathrm{E}-06$ & $4.99 \mathrm{E}-06$ & $5.52 \mathrm{E}-06$ \\
\hline En-154 & $6.29 \mathrm{E}-04$ & 0.422 & $2.27 \mathrm{E}+03$ & 4.03E-04 & 4.03E-04 & $7.10 \mathrm{E}-04$ & 7.47E-04 \\
\hline Eu-155 & $2.66 \mathrm{E}-04$ & 0.179 & 961 & $2.00 \mathrm{E}-04$ & $2.00 \mathrm{E}-04$ & $2.99 \mathrm{E}-04$ & $3.31 \mathrm{E}-04$ \\
\hline Ra-226 & $1.46 \mathrm{E}-10$ & 9.78E-08 & 5.25E-04 & $1.18 \mathrm{E}-10$ & $1.18 \mathrm{E}-10$ & $1.56 \mathrm{E}-10$ & $1.65 \mathrm{E}-10$ \\
\hline Ra-228 & $3.08 \mathrm{E}-07$ & $2.07 \mathrm{E}-04$ & 1.11 & $8.87 \mathrm{E}-08$ & $8.87 \mathrm{E}-08$ & 3.40E-07 & $3.74 \mathrm{E}-07$ \\
\hline Ac-227 & $8.78 \mathrm{E}-10$ & $5.89 \mathrm{E}-07$ & $3.17 \mathrm{E}-03$ & $7.15 \mathrm{E}-10$ & 7.15E-10 & $9.36 \mathrm{E}-10$ & 9.93E-10 \\
\hline $\mathrm{Pa}-231$ & $3.79 \mathrm{E}-09$ & $2.54 \mathrm{E}-06$ & $1.37 \mathrm{E}-02$ & $2.88 \mathrm{E}-09$ & $2.88 \mathrm{E}-09$ & $4.11 \mathrm{E}-09$ & 4.43E-09 \\
\hline Th-229 & $7.16 \mathrm{E}-09$ & $4.81 \mathrm{E}-06$ & $2.58 \mathrm{E}-02$ & $2.08 \mathrm{E}-09$ & $2.08 \mathrm{E}-09$ & $7.85 \mathrm{E}-09$ & $8.59 \mathrm{E}-09$ \\
\hline Th-232 & 3.29E- 08 & $2.21 \mathrm{E}-05$ & 0.119 & 5.73E-09 & $5.73 \mathrm{E}-09$ & 4.03E-08 & 4.75E-08 \\
\hline U-232 & $9.37 \mathrm{E}-07$ & $6.30 \mathrm{E}-04$ & 3.38 & $7.24 \mathrm{E}-07$ & $8.14 \mathrm{E}-07$ & $1.08 \mathrm{E}-06$ & $1.23 \mathrm{E}-06$ \\
\hline U-233 & $3.59 \mathrm{E}-06$ & $2.41 \mathrm{E}-03$ & 13.0 & $2.78 \mathrm{E}-06$ & $3.12 \mathrm{E}-06$ & 4.13E- 06 & 4.71E- 06 \\
\hline U-234 & $6.08 \mathrm{E}-07$ & $4.08 \mathrm{E}-04$ & 2.19 & $5.88 \mathrm{E}-07$ & $6.00 \mathrm{E}-07$ & $6.16 \mathrm{E}-07$ & $6.23 \mathrm{E}-07$ \\
\hline U-235 & $2.41 \mathrm{E}-08$ & $1.62 \mathrm{E}-05$ & $8.70 \mathrm{E}-02$ & $2.33 \mathrm{E}-08$ & $2.38 \mathrm{E}-08$ & $2.45 \mathrm{E}-08$ & $2.48 \mathrm{E}-08$ \\
\hline U-236 & $1.96 \mathrm{E}-08$ & $1.31 \mathrm{E}-05$ & 7.05E-02 & $1.90 \mathrm{E}-08$ & $1.93 \mathrm{E}-08$ & $1.98 \mathrm{E}-08$ & $2.00 \mathrm{E}-08$ \\
\hline U-238 & $8.34 \mathrm{E}-07$ & $5.60 \mathrm{E}-04$ & 3.01 & $8.15 \mathrm{E}-07$ & $8.26 \mathrm{E}-07$ & $8.42 \mathrm{E}-07$ & $8.68 \mathrm{E}-07$ \\
\hline Nn-237 & $8.40 \mathrm{E}-07$ & $5.64 \mathrm{E}-04$ & 3.03 & $6.67 \mathrm{E}-07$ & 7.51E-07 & $9.38 \mathrm{E}-07$ & $1.07 \mathrm{E}-06$ \\
\hline $\mathrm{Pu}-238_{2}$ & 1.40E-06 & 9.39E-04 & 5.05 & $1.20 \mathrm{E}-06$ & $1.30 \mathrm{E}-06$ & $1.50 \mathrm{E}-06$ & $1.60 \mathrm{E}-06$ \\
\hline $\mathrm{Pu}-239$ & $5.00 \mathrm{E}-05$ & $3.36 \mathrm{E}-02$ & 181 & 4.48E-05 & $4.74 \mathrm{E}-05$ & $5.27 \mathrm{E}-05$ & $5.52 \mathrm{E}-05$ \\
\hline $\mathrm{Pu}_{\mathrm{u}-240}$ & $8.47 \mathrm{E}-06$ & $5.69 \mathrm{E}-03$ & 30.6 & 7.51E-06 & $7.98 \mathrm{E}-06$ & $8.97 \mathrm{E}-06$ & 9.44E-06 \\
\hline $\mathrm{Pu}-241$ & $9.75 \mathrm{E}-05$ & $6.55 \mathrm{E}-02$ & 352 & $8.37 \mathrm{E}-05$ & $9.05 \mathrm{E}-05$ & $1.05 \mathrm{E}-04$ & $1.11 \mathrm{E}-04$ \\
\hline $\mathrm{Pu}-242$ & $5.19 \mathrm{E}-10$ & $3.49 \mathrm{E}-07$ & $1.87 \mathrm{E}-03$ & $4.37 \mathrm{E}-10$ & $4.77 \mathrm{E}-10$ & $5.61 \mathrm{E}-10$ & $6.02 \mathrm{E}-10$ \\
\hline$\Delta \mathrm{m}-241$ & $5.47 \mathrm{E}-05$ & $3.68 \mathrm{E}-02$ & 197 & $4.51 \mathrm{E}-05$ & 4.98E-05 & $5.96 \mathrm{E}-05$ & $6.43 \mathrm{E}-05$ \\
\hline$\Delta \mathrm{m}-243$ & $2.01 \mathrm{E}-09$ & $1.35 \mathrm{E}-06$ & $7.26 \mathrm{E}-03$ & $1.63 \mathrm{E}-09$ & $1.81 \mathrm{E}-09$ & $2.25 \mathrm{E}-09$ & 2.46E-09 \\
\hline $\mathrm{Cm}-242$ & $1.48 \mathrm{E}-07$ & 9.97E-05 & 0.536 & $1.03 \mathrm{E}-07$ & $1.03 \mathrm{E}-07$ & $1.69 \mathrm{E}-07$ & $1.89 \mathrm{E}-07$ \\
\hline $\mathrm{Cm}-243$ & $1.36 \mathrm{E}-08$ & 9.11E-06 & $4.89 \mathrm{E}-02$ & $9.18 \mathrm{E}-09$ & $9.18 \mathrm{E}-09$ & $1.54 \mathrm{E}-08$ & $1.72 \mathrm{E}-08$ \\
\hline $\mathrm{Cm}-244$ & $1.10 \mathrm{E}-07$ & $7.39 \mathrm{E}-05$ & 0.397 & $6.48 \mathrm{E}-08$ & $6.48 \mathrm{E}-08$ & $1.25 \mathrm{E}-07$ & $1.35 \mathrm{E}-07$ \\
\hline Tatals & $\mathbf{M}$ & 110/0 & $\mathbf{k o}$ & 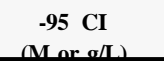 & $\begin{array}{c}-67 \mathrm{CI} \\
\mathrm{M} / \mathrm{ar} / \mathrm{dL})\end{array}$ & $\begin{array}{c}+67 \mathrm{CI} \\
\text { Mor } \sigma / L\end{array}$ & $4 \sigma \alpha a / L)$ \\
\hline $\mathrm{Pu}$ & $6.04 \mathrm{E}-04(\mathrm{~g} / \mathrm{L})$ & $\ldots$ & 2.18 & $5.06 \mathrm{E}-04$ & $5.54 \mathrm{E}-04$ & $6.54 \mathrm{E}-04$ & 7.02E-04 \\
\hline $\mathrm{U}$ & $6.82 \mathrm{E}-03$ & $1.09 \mathrm{E}+03$ & $5.86 \mathrm{E}+03$ & $6.59 \mathrm{E}-03$ & $6.73 \mathrm{E}-03$ & $6.93 \mathrm{E}-03$ & $7.00 \mathrm{E}-03$ \\
\hline
\end{tabular}

*Unknowns in tank solids inventory are assigned by Tank Layering Model (TLM).

$\dagger$ Volume average for density, mass average Water wt $\%$ and TOC wt $\% \mathrm{C}$. 
HDW Model Rev. 4

\begin{tabular}{|c|c|c|c|c|c|c|c|}
\hline & \multicolumn{7}{|c|}{ Single-Shell Tank 241-A-102 } \\
\hline & \multicolumn{7}{|c|}{ Total Inventory Estimate* } \\
\hline $\begin{array}{l}\text { Physical } \\
\text { Pronerties }\end{array}$ & & & & .95 CI & $-67 C L$ & +67 CL & $+95 \mathrm{CL}$ \\
\hline Total Waste & $6 \mathrm{~F}+050 \mathrm{k}$ & & & & & & \\
\hline Heat Load & $102 \mathrm{~kW}$ & $(3,49 \mathrm{E}+03 \mathrm{BTU} / \mathrm{hr}$ & & 0.260 & 0.752 & 1.15 & 122 \\
\hline Bulk Density $\dagger$ & $1.52(\mathrm{~g} / \mathrm{cc}$ & & & 1.46 & 1.50 & 1.54 & 1.55 \\
\hline Water wt $\% \dagger$ & 40.0 & & & 372 & 38.4 & 41.5 & 43.4 \\
\hline TOC wt $\% \mathrm{C}$ (we & 1.49 & & & 0766 & 113 & 185 & 216 \\
\hline $\begin{array}{c}\text { Chemical } \\
\text { Constituents }\end{array}$ & mole $/ L$ & nom & $\mathbf{k g}$ & $\begin{array}{c}-95 \text { CI } \\
(\text { mole/L) }\end{array}$ & $\begin{array}{c}-67 \mathrm{CI} \\
(\mathrm{mole} / \mathrm{L})\end{array}$ & $\begin{array}{c}+67 \mathrm{CI} \\
(\mathrm{mole} / \mathrm{L})\end{array}$ & $\begin{array}{c}\text { +95 CI } \\
\text { (mole/L) }\end{array}$ \\
\hline $\mathrm{Na}+$ & 11.9 & $1.79 \mathrm{E}+05$ & $4.23 \mathrm{E}+04$ & 10.7 & 113 & 123 & 126 \\
\hline $\mathrm{Al} 3+$ & 1.43 & $2.54 \mathrm{E}+04$ & $6.00 \mathrm{E}+03$ & 117 & 1.37 & 1.47 & 1.50 \\
\hline $\mathrm{Fe} 3+($ total Fe) & 0.101 & $3.71 \mathrm{E}+03$ & 877 & $282 \mathrm{E}-02$ & $868 \mathrm{E}-02$ & 0107 & 0111 \\
\hline $\mathrm{Cr} 3+$ & $9.79 \mathrm{E}-02$ & $3.34 \mathrm{E}+03$ & 790 & $874 \mathrm{E}-02$ & $924 \mathrm{E}-02$ & 0103 & 0111 \\
\hline $\mathrm{Bi} 3+$ & $1.04 \mathrm{E}-03$ & 143 & 33.7 & $071 \mathrm{E}-04$ & $101 \mathrm{E}-02$ & $108 E_{-} 03$ & $113 E_{-} 03$ \\
\hline $\mathrm{La} 3+$ & $1.87 \mathrm{E}-05$ & 1.71 & 0.403 & $1.38 \mathrm{E}-05$ & $162 \mathrm{E}-05$ & $2.12 \mathrm{E}-05$ & $2.36 \mathrm{E}-05$ \\
\hline $\mathrm{Hg} 2+$ & $8.44 \mathrm{E}-06$ & 1.11 & 0.263 & $8.05 \mathrm{E}-06$ & $825 \mathrm{E}-06$ & $8.63 \mathrm{E}-06$ & $8.82 \mathrm{E}-06$ \\
\hline $\mathrm{Zr}$ (as $\mathrm{ZrO}(\mathrm{OH}) 2)$ & $1.24 \mathrm{E}-04$ & 7.40 & 1.75 & $1.14 \mathrm{E}-04$ & $118 \mathrm{E}-04$ & $127 \mathrm{E}-04$ & $133 \mathrm{E}-04$ \\
\hline $\mathrm{Pb} 2+$ & $1.16 \mathrm{E}-03$ & 157 & 37.2 & $8.77 \mathrm{E}-04$ & $101 \mathrm{E}-03$ & $1.30 \mathrm{E}-03$ & $1.44 \mathrm{E}-03$ \\
\hline $\mathrm{Ni} 2+$ & $4.25 \mathrm{E}-03$ & 164 & 38.7 & $408 \mathrm{E}-03$ & $416 \mathrm{E}-03$ & $429 \mathrm{E}-03$ & $4.33 \mathrm{E}_{-} 03$ \\
\hline $\operatorname{Sr} 2+$ & 0 & 0 & 0 & & 0 & 0 & \\
\hline Mn4+ & $3.92 \mathrm{E}-03$ & 141 & 33.4 & $3.40 \mathrm{E}-03$ & $365 \mathrm{E}-03$ & $418 \mathrm{E}-03$ & $4.43 \mathrm{E}-03$ \\
\hline $\mathrm{Ca} 2+$ & $3.33 \mathrm{E}-02$ & 876 & 207 & $224 \mathrm{E}-02$ & $235 \mathrm{E}-02$ & $404 \mathrm{E}-02$ & $442 \mathrm{E}-02$ \\
\hline $\mathrm{K}+$ & $5.58 \mathrm{E}-02$ & $1.43 \mathrm{E}+03$ & 339 & $4.72 \mathrm{E}-02$ & $508 \mathrm{E}-02$ & $6.16 \mathrm{E}-02$ & $6.95 \mathrm{E}-02$ \\
\hline $\mathrm{OH}-$ & 8.29 & $9.26 \mathrm{E}+04$ & $2.19 \mathrm{E}+04$ & 7.05 & 7.94 & 8.47 & 8.62 \\
\hline NO3- & 3.60 & $1.46 \mathrm{E}+05$ & $3.46 \mathrm{E}+04$ & 330 & 340 & 370 & 380 \\
\hline NO2- & 2.13 & $6.45 \mathrm{E}+04$ & $1.52 \mathrm{E}+04$ & 168 & 187 & 2.42 & 250 \\
\hline $\mathrm{CO} 32-$ & 0.461 & $1.82 \mathrm{E}+04$ & $4.29 \mathrm{E}+03$ & 0.406 & 0,429 & 0.490 & 0.530 \\
\hline PO43- & $7.90 \mathrm{E}-02$ & $4.93 \mathrm{E}+03$ & $1.16 \mathrm{E}+03$ & $675 \mathrm{E}-02$ & $725 \mathrm{E}-02$ & $8425-02$ & $000 \mathrm{E}-025 \mathrm{C}$ \\
\hline SO42- & 0.250 & $1.58 \mathrm{E}+04$ & $3.72 \mathrm{E}+03$ & 0.197 & 0.219 & 0286 & 0289 \\
\hline $\mathrm{Si}$ (as $\mathrm{SiO} 32-$ ) & 0.195 & $3.60 \mathrm{E}+03$ & 850 & $618 \mathrm{E}-02$ & 0.134 & 0222 & 0238 \\
\hline F- & $5.70 \mathrm{E}-02$ & 712 & 168 & $4.79 \mathrm{E}-02$ & $5.16 \mathrm{E}-02$ & $6.30 \mathrm{E}-02$ & $7.19 \mathrm{E}-02$ \\
\hline $\mathrm{Cl}-$ & 0.201 & $4.68 \mathrm{E}+03$ & $1.11 \mathrm{E}+03$ & 0.171 & 0.184 & 0.207 & 0.212 \\
\hline C6H5O73- & $2.82 \mathrm{E}-02$ & $3.51 \mathrm{E}+03$ & 828 & $256 \mathrm{E}-02$ & $267 \mathrm{E}-02$ & $290 \mathrm{E}-02$ & $325 \mathrm{E}-02$ \\
\hline EDTA4- & $4.04 \mathrm{E}-02$ & $7.65 \mathrm{E}+03$ & $1.81 \mathrm{E}+03$ & $126 \mathrm{E}-02$ & $264 \mathrm{E}-02$ & $5.44 \mathrm{E}-02$ & $6.69 \mathrm{E}-02$ \\
\hline HEDTA3- & 7.44E-02 & $1.34 \mathrm{E}+04$ & $3.16 \mathrm{E}+03$ & $188 \mathrm{E}-02$ & $464 \mathrm{E}-02$ & 0102 & 0.127 \\
\hline glycolate- & 0.130 & $6.39 \mathrm{E}+03$ & $1.51 \mathrm{E}+03$ & $741 \mathrm{E}-02$ & 0.102 & 0.158 & 0.183 \\
\hline acetate- & $2.07 \mathrm{E}-02$ & 803 & 190 & $163 \mathrm{E}-02$ & $182 \mathrm{E}-02$ & $234 \mathrm{E}-02$ & $275 \mathrm{E}-02$ \\
\hline oxalate2- & $2.45 \mathrm{E}-05$ & 1.42 & 0.335 & $210 \mathrm{E}_{-} 05$ & $232 \mathrm{E}-05$ & $250 \mathrm{E}-05$ & $272 \mathrm{E}-05$ \\
\hline DBP & $2.30 \mathrm{E}-02$ & $3.17 \mathrm{E}+03$ & 749 & $189 \mathrm{E}-02$ & $206 \mathrm{E}-02$ & $2.55 \mathrm{E}-02$ & $292 \mathrm{E}-02$ \\
\hline butanol & $2.30 \mathrm{E}-02$ & $1.12 \mathrm{E}+03$ & 264 & $189 \mathrm{E}-02$ & $206 \mathrm{E}-02$ & $255 \mathrm{E}-02$ & $292 \mathrm{E}-02$ \\
\hline NH3 & $5.87 \mathrm{E}-02$ & 656 & 155 & $4.82 \mathrm{E}-02$ & $5.32 \mathrm{E}-02$ & $6.51 \mathrm{E}-02$ & $7.26 \mathrm{E}-02$ \\
\hline $\mathrm{Fe}(\mathrm{CN}) 64-$ & 0 & 0 & 0 & 0 & 0 & 0 & 0 \\
\hline
\end{tabular}

*Unknowns in tank solids inventory are assigned by Tank Layering Model (TLM).

$\dagger$ Water wt $\%$ derived from the difference of density and total dissolved species. 
HDW Model Rev. 4

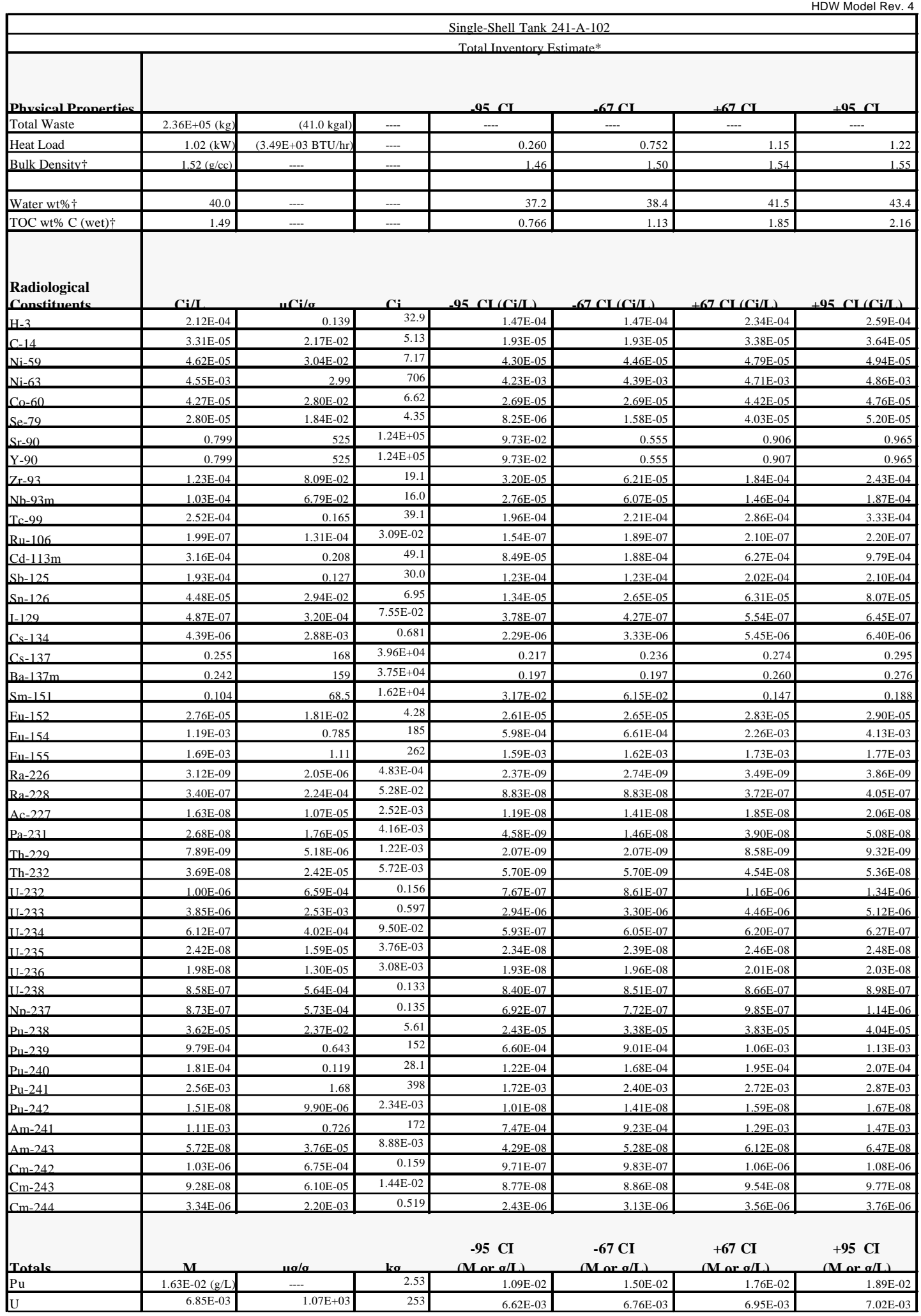

*Unknowns in tank solids inventory are assigned by Tank Layering Model (TLM)

$\nmid$ Volume average for density, mass average Water wt $\%$ and TOC wt $\%$ C. 
HDW Model Rev. 4

\begin{tabular}{|c|c|c|c|c|c|c|c|}
\hline \multicolumn{8}{|c|}{ Single-Shell Tank 241-A-103 } \\
\hline & \multicolumn{7}{|c|}{ Total Inventorv Estimate* } \\
\hline $\begin{array}{l}\text { Physical } \\
\text { Pronerties }\end{array}$ & & & & $-25 \mathrm{CL}$ & $-67 \mathrm{CI}$ & $\pm 67 \mathrm{CL}$ & $+95 \mathrm{CL}$ \\
\hline Total Waste & $2.13 \mathrm{E}+06(\mathrm{~kg}$ & $(371 \mathrm{kgall}$ & & & & & \\
\hline Heat Load & $357(\mathrm{~kW}$ & $(122 \mathrm{E}+04 \mathrm{BT} / \mathrm{hr}$ & & 330 & 345 & 368 & 384 \\
\hline Bulk Density $t$ & $1.52(\mathrm{~g} / \mathrm{cc})$ & & & 1.46 & 149 & 1.54 & 1.54 \\
\hline & & & & & & & \\
\hline Water wt\%t & 40.2 & & & 377 & 385 & 417 & 437 \\
\hline TOC wt $\% \mathrm{C}$ (wet)t & 1.28 & $\ldots$ & $\ldots$ & 0.711 & 0.989 & 1.56 & 1.84 \\
\hline $\begin{array}{c}\begin{array}{c}\text { Chemical } \\
\text { Constitwents }\end{array} \\
\end{array}$ & mole/L & nnm & kg & $\begin{array}{c}-95 \text { CI } \\
(\mathrm{mole} / \mathrm{L})\end{array}$ & $\begin{array}{c}-67 \mathrm{CI} \\
(\mathrm{mole} / \mathrm{L}) \\
\end{array}$ & $\begin{array}{c}+67 \mathrm{CI} \\
(\mathrm{mole} / \mathrm{L})\end{array}$ & $\begin{array}{c}\text { +95 CI } \\
\text { (mole/L) }\end{array}$ \\
\hline $\mathrm{Na}+$ & 11.8 & $1.79 \mathrm{E}+05$ & $3.81 \mathrm{E}+05$ & 107 & 113 & 12.3 & 126 \\
\hline $\mathrm{Al} 3+$ & 1.48 & $2.64 \mathrm{E}+04$ & $5.62 \mathrm{E}+04$ & 121 & 142 & 1.52 & 1.56 \\
\hline $\mathrm{Fe} 3+($ total $\mathrm{Fe}$ ) & $1.86 \mathrm{E}-02$ & 683 & $1.46 \mathrm{E}+03$ & $174 \mathrm{E}-02$ & 1 - $80 \mathrm{E}-02$ & $101 \mathrm{E}-02$ & 07E_-02 \\
\hline $\mathrm{Cr} 3+$ & 0.101 & $3.47 \mathrm{E}+03$ & $7.40 \mathrm{E}+03$ & 9.04E-02 & $2.57 \mathrm{E}-02$ & 0.107 & 0.115 \\
\hline $\mathrm{Bi} 3+$ & $1.07 \mathrm{E}-03$ & 148 & 315 & $100 \mathrm{E}-03$ & $104 \mathrm{E}-03$ & $111 \mathrm{E}-03$ & $1217 \mathrm{E}-03$ \\
\hline $\mathrm{La} 3+$ & $1.92 \mathrm{E}-05$ & 1.76 & 3.75 & $142 E_{-} 05$ & $167 \mathrm{E}-05$ & $218 \mathrm{E}_{-05}$ & $243 \mathrm{E}-05$ \\
\hline $\mathrm{Hg} 2+$ & $8.71 \mathrm{E}-06$ & 1.15 & 2.45 & $8.32 \mathrm{E}-06$ & $8.52 \mathrm{E}-06$ & $8.92 \mathrm{E}-06$ & $211 \mathrm{E}-06$ \\
\hline $\mathrm{Zr}$ (as $\mathrm{ZrO}(\mathrm{OH}) 2$ ) & $1.28 \mathrm{E}-04$ & 7.68 & 16.4 & $1218 \mathrm{E}-04$ & $122 \mathrm{E}-04$ & $1.32 \mathrm{E}-04$ & $1.37 \mathrm{E}-04$ \\
\hline $\mathrm{Pb} 2+$ & $1.19 \mathrm{E}-03$ & 163 & 348 & $206 \mathrm{E}-04$ & $105 \mathrm{E}-03$ & $1.34 \mathrm{E}-03$ & $148 \mathrm{E}-03$ \\
\hline $\mathrm{Ni} 2+$ & $5.52 \mathrm{E}-03$ & 214 & 455 & $5.35 \mathrm{E}-03$ & $5.43 \mathrm{E}-03$ & $5.57 \mathrm{E}-03$ & $5.60 \mathrm{E}-03$ \\
\hline $\mathrm{Sr} 2+$ & 0 & 0 & 0 & & & & ــ \\
\hline Mn4+ & $4.06 \mathrm{E}-03$ & 147 & 313 & $3.53 \mathrm{E}-03$ & $3.79 \mathrm{E}-03$ & $4.33 \mathrm{E}-03$ & $4.59 \mathrm{E}-03$ \\
\hline $\mathrm{Ca} 2+$ & $2.50 \mathrm{E}-02$ & 659 & $1.40 \mathrm{E}+03$ & $2.34 \mathrm{E}-02$ & $2.41 \mathrm{E}-02$ & $2.58 \mathrm{E}-02$ & $266 \mathrm{E}-02$ \\
\hline $\mathrm{K}+$ & 5.69E-02 & $1.46 \mathrm{E}+03$ & $3.12 \mathrm{E}+03$ & $\triangle \triangle 80 E-02$ & 5 17E- 02 & $628 \mathrm{E}-02$ & $700 \mathrm{E}-02$ \\
\hline $\mathrm{OH}-$ & 8.31 & $9.31 \mathrm{E}+04$ & $1.98 \mathrm{E}+05$ & 7.04 & 796 & 8.50 & 8.65 \\
\hline $\mathrm{NO} 3-$ & 3.72 & $1.52 \mathrm{E}+05$ & $3.24 \mathrm{E}+05$ & 3.51 & 3.61 & 3.82 & 3.93 \\
\hline $\mathrm{NO} 2-$ & 2.17 & $6.57 \mathrm{E}+04$ & $1.40 \mathrm{E}+05$ & 170 & 190 & 2.46 & 2.54 \\
\hline $\mathrm{CO} 32-$ & 0.452 & $1.79 \mathrm{E}+04$ & $3.81 \mathrm{E}+04$ & 0.417 & 0.434 & 0.470 & 0.481 \\
\hline $\mathrm{PO} 43-$ & $8.17 \mathrm{E}-02$ & $5.11 \mathrm{E}+03$ & $1.09 \mathrm{E}+04$ & $698 \mathrm{E}-02$ & 7 49E- -02 & 8 7 70E-02 & $240 \mathrm{E}-02$ \\
\hline SO42- & 0.252 & $1.59 \mathrm{E}+04$ & $3.40 \mathrm{E}+04$ & 0.197 & 0.220 & 0.289 & 0.292 \\
\hline $\mathrm{Si}$ (as $\mathrm{SiO} 32-$ ) & $8.37 \mathrm{E}-02$ & $1.55 \mathrm{E}+03$ & $3.30 \mathrm{E}+03$ & $7.61 \mathrm{E}-02$ & $7.98 \mathrm{E}-02$ & $8.76 \mathrm{E}-02$ & $2.13 \mathrm{E}-02$ \\
\hline F- & $5.89 \mathrm{E}-02$ & 737 & $1.57 \mathrm{E}+03$ & $494 \mathrm{E}-02$ & $533 \mathrm{E}-02$ & $650 \mathrm{E}-02$ & $742 \mathrm{E}-02$ \\
\hline $\mathrm{Cl}-$ & 0.204 & $4.76 \mathrm{E}+03$ & $1.02 \mathrm{E}+04$ & 0.172 & 0.187 & 0.210 & 0215 \\
\hline C6H5O73- & $2.92 \mathrm{E}-02$ & $3.64 \mathrm{E}+03$ & $7.76 \mathrm{E}+03$ & $265 \mathrm{E}-02$ & $276 \mathrm{E}-02$ & $3.09 \mathrm{E}-02$ & $3.36 \mathrm{E}-02$ \\
\hline EDTA4- & $3.17 \mathrm{E}-02$ & $6.02 \mathrm{E}+03$ & $1.28 \mathrm{E}+04$ & $103 \mathrm{E}-02$ & $208 \mathrm{E}-02$ & 4.27E- 02 & $535 \mathrm{E}-02$ \\
\hline HEDTA3- & $5.68 \mathrm{E}-02$ & $1.03 \mathrm{E}+04$ & $2.19 \mathrm{E}+04$ & $140 \mathrm{E}-02$ & $3.49 \mathrm{E}-02$ & $788 \mathrm{E}-02$ & 0.100 \\
\hline glycolate- & 0.114 & $5.65 \mathrm{E}+03$ & $1.20 \mathrm{E}+04$ & $716 \mathrm{E}-02$ & $925 \mathrm{E}-02$ & 0136 & 0158 \\
\hline acetate- & $2.14 \mathrm{E}-02$ & 831 & $1.77 \mathrm{E}+03$ & $169 \mathrm{E}-02$ & $1.88 \mathrm{E}-02$ & $2.41 \mathrm{E}-02$ & $2.84 \mathrm{E}-02$ \\
\hline oxalate2- & $2.52 \mathrm{E}-05$ & 1.46 & 3.11 & $225 \mathrm{E}-05$ & $238 \mathrm{E}-05$ & $266 \mathrm{E}-05$ & $279 \mathrm{E}-05$ \\
\hline DBP & $2.37 \mathrm{E}-02$ & $3.28 \mathrm{E}+03$ & $7.00 \mathrm{E}+03$ & $195 \mathrm{E}-02$ & 2 13E- 02 & $2.63 \mathrm{E}-02$ & $3.01 \mathrm{E}-02$ \\
\hline butanol & $2.37 \mathrm{E}-02$ & $1.16 \mathrm{E}+03$ & $2.47 \mathrm{E}+03$ & $195 \mathrm{E}-02$ & 2 13E- 02 & $2.63 \mathrm{E}-02$ & $3.01 \mathrm{E}-02$ \\
\hline NH3 & $5.22 \mathrm{E}-02$ & 585 & $1.25 \mathrm{E}+03$ & $4.36 \mathrm{E}-02$ & $470 \mathrm{E}-02$ & $588 \mathrm{E}-02$ & $6.66 \mathrm{E}-02$ \\
\hline $\mathrm{Fe}(\mathrm{CN}) 64-$ & 0 & 0 & 0 & 0 & 0 & 0 & 0 \\
\hline
\end{tabular}

*Unknowns in tank solids inventory are assigned by Tank Layering Model (TLM).

$\dagger$ Water wt $\%$ derived from the difference of density and total dissolved species. 
HDW Model Rev. 4



*Unknowns in tank solids inventory are assigned by Tank Layering Model (TLM).

$\doteqdot$ Volume average for density, mass average Water wt $\%$ and TOC wt $\%$ C. 
HDW Model Rev. 4

\begin{tabular}{|c|c|c|c|c|c|c|c|}
\hline \multicolumn{8}{|c|}{ Single-Shell Tank 241-A-104 } \\
\hline & \multicolumn{7}{|c|}{ TotaL Inventory Estimate* } \\
\hline $\begin{array}{l}\text { Physical } \\
\text { Pronerties }\end{array}$ & & & & $.05 \mathrm{CL}$ & $=67$ CI & $+67 \mathrm{CL}$ & $+05 \mathrm{CI}$ \\
\hline Total Waste & $1.38 \mathrm{E}+05(\mathrm{~kg})$ & $28.0 \mathrm{kgall}$ & & & & & \\
\hline Heat Load & $8.95(\mathrm{~kW})$ & $(3.06 \mathrm{E}+04 \mathrm{BT} U / \mathrm{hr})$ & & 8.80 & 8.87 & 903 & 910 \\
\hline Bulk Density & $1.30(\mathrm{~g} / \mathrm{cc})$ & & & 120 & 130 & 131 & 131 \\
\hline Water wt $\%+$ & 69.1 & & & 68.7 & 68.9 & 69.4 & 697 \\
\hline TOC wt\% C (wet & 0 & & & & & & \\
\hline $\begin{array}{c}\text { Chemical } \\
\text { Constituents }\end{array}$ & mole/L & nnm & $\mathbf{k o}$ & $\begin{array}{c}-95 \text { CI } \\
\text { (mole/I) }\end{array}$ & $\begin{array}{c}-67 \mathrm{CI} \\
(\mathrm{mole} / \mathrm{L})\end{array}$ & $\begin{array}{c}+67 \mathrm{CI} \\
(\mathrm{mole} / \mathrm{L})\end{array}$ & $\begin{array}{c}\text { +95 CI } \\
\text { (mole/L) }\end{array}$ \\
\hline $\mathrm{Na}+$ & 5.51 & $9.75 \mathrm{E}+04$ & $1.34 \mathrm{E}+04$ & 511 & 5.36 & 566 & 580 \\
\hline $\mathrm{Al} 3+$ & $6.85 \mathrm{E}-02$ & $1.42 \mathrm{E}+03$ & 196 & $6.84 \mathrm{E}-02$ & $6.85 \mathrm{E}-02$ & $6.87 \mathrm{E}-02$ & $6.88 \mathrm{E}-02$ \\
\hline $\mathrm{Fe} 3+($ total Fe) & 1.35 & $5.79 \mathrm{E}+04$ & $7.98 \mathrm{E}+03$ & 1.34 & 1.35 & 1.35 & 1.35 \\
\hline $\mathrm{Cr} 3+$ & $1.39 \mathrm{E}-02$ & 557 & 76.7 & $138 \mathrm{E}-02$ & $139 \mathrm{E}-02$ & $1.10 \mathrm{E}-02$ & $141 \mathrm{E}-02$ \\
\hline $\mathrm{Bi} 3+$ & $9.29 \mathrm{E}-06$ & 1.49 & 0.206 & $785 \mathrm{E}-06$ & $8.56 \mathrm{E}-06$ & $100 \mathrm{E}-05$ & $107 \mathrm{E}-05$ \\
\hline $\mathrm{La} 3+$ & 0 & 0 & 0 & & & & \\
\hline $\mathrm{Hg} 2+$ & $2.91 \mathrm{E}-07$ & $4.50 \mathrm{E}-02$ & $6.19 \mathrm{E}-03$ & $2.62 \mathrm{E}-07$ & $2.77 \mathrm{E}-07$ & $3.06 \mathrm{E}-07$ & $3.21 \mathrm{E}-07$ \\
\hline $\mathrm{Zr}$ (as $\mathrm{ZrO}(\mathrm{OH}) 2)$ & 3.67E- 08 & $2.58 \mathrm{E}-03$ & 3.55E-04 & $3.64 \mathrm{E}-08$ & $3.65 \mathrm{E}-08$ & $3.69 \mathrm{E}-08$ & $3.72 \mathrm{E}-08$ \\
\hline $\mathrm{Pb} 2+$ & 4.77E-05 & 7.60 & 1.05 & $265 \mathrm{E}-05$ & $360 \mathrm{E}-05$ & $585 \mathrm{E}-05$ & $6.89 \mathrm{E}-05$ \\
\hline $\mathrm{Ni} 2+$ & 0.138 & $6.22 \mathrm{E}+03$ & 856 & 0.134 & 0.137 & 0.138 & 0.139 \\
\hline $\mathrm{Sr} 2+$ & 0 & 0 & 0 & 0 & 0 & 0 & 0 \\
\hline Mn4+ & $2.13 \mathrm{E}-03$ & 90.2 & 12.4 & $\triangle 8 E_{-} 03$ & $180 \mathrm{E}-03$ & $247 \mathrm{E}-03$ & $270 \mathrm{E}-03$ \\
\hline $\mathrm{Ca} 2+$ & 0.121 & $3.73 \mathrm{E}+03$ & 514 & 0.102 & مـ111 & 0.131 & 0.140 \\
\hline$\underline{\mathrm{K}}+$ & $6.23 \mathrm{E}-03$ & 187 & 25.8 & $617 \mathrm{E}-03$ & $620 \mathrm{E}-03$ & $627 \mathrm{E}-03$ & $632 \mathrm{E}-03$ \\
\hline $\mathrm{OH}-$ & 4.63 & $6.05 \mathrm{E}+04$ & $8.34 \mathrm{E}+03$ & 4.61 & 4.62 & 4.64 & 4.65 \\
\hline NO3- & $1.57 \mathrm{E}-09$ & 7.47E-05 & $1.03 \mathrm{E}-05$ & $1.13 \mathrm{E}-09$ & $1.33 \mathrm{E}-09$ & $1.85 \mathrm{E}-09$ & $217 \mathrm{E}-09$ \\
\hline $\mathrm{NO} 2-$ & 0.631 & $2.23 \mathrm{E}+04$ & $3.07 \mathrm{E}+03$ & 0.618 & 0.624 & 0.634 & 0.630 \\
\hline $\mathrm{CO} 32-$ & 0.231 & $1.06 \mathrm{E}+04$ & $1.47 \mathrm{E}+03$ & 0.212 & 0.221 & 0.240 & 0.249 \\
\hline PO43- & $1.88 \mathrm{E}-02$ & $1.37 \mathrm{E}+03$ & 189 & $1.86 \mathrm{E}-02$ & $1.87 \mathrm{E}-02$ & $189 \mathrm{E}-02$ & $191 \mathrm{E}-02$ \\
\hline $\mathrm{SO} 42-$ & $6.68 \mathrm{E}-02$ & $4.94 \mathrm{E}+03$ & 680 & $662 \mathrm{E}-02$ & $605 \mathrm{E}-02$ & $672 \mathrm{E}-02$ & $677 \mathrm{E}-02$ \\
\hline $\mathrm{Si}$ (as $\mathrm{SiO} 32-$ ) & 2.21 & $4.77 \mathrm{E}+04$ & $6.58 \mathrm{E}+03$ & 200 & 213 & 229 & 2.36 \\
\hline F- & $3.12 \mathrm{E}-04$ & 4.56 & 0.628 & $292 \mathrm{E}-04$ & $308 \mathrm{E}-04$ & 3 14E-04 & $316 \mathrm{E}-04$ \\
\hline $\mathrm{Cl}-$ & $1.57 \mathrm{E}-02$ & 427 & 58.8 & $1.55 \mathrm{E}-02$ & $1.56 \mathrm{E}-02$ & $1.58 \mathrm{E}-02$ & $1.59 \mathrm{E}-02$ \\
\hline $\mathrm{C} 6 \mathrm{H} 5 \mathrm{O} 73-$ & 0 & 0 & 0 & 0 & 0 & 0 & 0 \\
\hline EDTA4- & 0 & 0 & 0 & & & مـ & \\
\hline HEDTA3- & 0 & 0 & 0 & 0 & 0 & 0 & 0 \\
\hline & & & & & & & \\
\hline glycolate- & 0 & 0 & 0 & 0 & مـ & مـ & \\
\hline acetate- & 0 & 0 & 0 & 0 & 0 & 0 & 0 \\
\hline oxalate2- & 0 & 0 & 0 & 0 & 0 & 0 & \\
\hline DBP & 0 & 0 & 0 & 0 & 0 & 0 & 0 \\
\hline butanol & 0 & 0 & 0 & 0 & 0 & 0 & 0 \\
\hline & & & & & & & \\
\hline $\mathrm{NH} 3$ & 0.200 & $2.62 \mathrm{E}+03$ & 361 & 0.197 & 0.199 & 0.203 & 0206 \\
\hline $\mathrm{Fe}(\mathrm{CN}) 64-$ & 0 & 0 & 0 & 0 & 0 & 0 & 0 \\
\hline
\end{tabular}

*Unknowns in tank solids inventory are assigned by Tank Layering Model (TLM).

$\dagger$ Water wt $\%$ derived from the difference of density and total dissolved species. 
HDW Model Rev. 4

\begin{tabular}{|c|c|c|c|c|c|c|c|}
\hline & \multirow{2}{*}{\multicolumn{7}{|c|}{$\begin{array}{c}\text { Single-Shell Tank 241-A-104 } \\
\text { TotaLInventory Estimate* }\end{array}$}} \\
\hline \multirow[b]{2}{*}{ PhysicalPronerties } & & & & & & & \\
\hline & & & & $.05 \mathrm{CI}$ & $-67 \mathrm{CI}$ & $+67 \mathrm{CI}$ & $+95 \mathrm{CI}$ \\
\hline Total Waste & $1.38 \mathrm{E}+05(\mathrm{~kg})$ & $(28.0 \mathrm{kgal})$ & $-\cdots$ & $\ldots$ & $-\cdots$ & --- & $\ldots$ \\
\hline Heat Load & $8.95(\mathrm{~kW})$ & $(3.06 \mathrm{E}+04 \mathrm{BTU} / \mathrm{hr})$ & $\ldots$ & 8.80 & 8.87 & 9.03 & 9.10 \\
\hline Bulk Density' & $1.30(\mathrm{~g} / \mathrm{cc})$ & 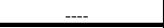 & $\ldots$ & 1.29 & 1.30 & 1.31 & 1.31 \\
\hline Water wt $\% \dagger$ & 69.1 & $\ldots$ & $\ldots$ & 68.7 & 68.9 & 69.4 & 69.7 \\
\hline TOC wt $\% \mathrm{C}$ (wet)t & 0 & - & $\ldots$ & 0 & 0 & 0 & 0 \\
\hline $\begin{array}{l}\text { Radiological } \\
\text { Conctitunntc }\end{array}$ & (1/L & سم/نCu & (i & 05_CL/CILIL & 67) & ) & 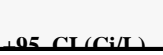 \\
\hline $\mathrm{H}-3$ & $5.72 \mathrm{E}-06$ & $4.40 \mathrm{E}-03$ & 0.606 & 4.97E-06 & $5.30 \mathrm{E}-06$ & $6.26 \mathrm{E}-06$ & $6.88 \mathrm{E}-06$ \\
\hline C-14 & $1.11 \mathrm{E}-05$ & $8.55 \mathrm{E}-03$ & 1.18 & $1.09 \mathrm{E}-05$ & $1.10 \mathrm{E}-05$ & $1.12 \mathrm{E}-05$ & $1.13 \mathrm{E}-05$ \\
\hline $\mathrm{Ni-59}$ & $1.12 \mathrm{E}-04$ & $8.58 \mathrm{E}-02$ & 11.8 & $1.07 \mathrm{E}-04$ & $1.09 \mathrm{E}-04$ & $1.14 \mathrm{E}-04$ & $1.17 \mathrm{E}-04$ \\
\hline Ni-63 & $1.09 \mathrm{E}-02$ & 8.41 & $1.16 \mathrm{E}+03$ & $1.05 \mathrm{E}-02$ & $1.07 \mathrm{E}-02$ & $1.12 \mathrm{E}-02$ & $1.14 \mathrm{E}-02$ \\
\hline $\mathrm{Co}-60$ & $1.12 \mathrm{E}-05$ & $8.58 \mathrm{E}-03$ & 1.18 & $1.10 \mathrm{E}-05$ & $1.11 \mathrm{E}-05$ & $1.12 \mathrm{E}-05$ & $1.17 \mathrm{E}-05$ \\
\hline Se-79 & $5.04 \mathrm{E}-05$ & $3.88 \mathrm{E}-02$ & 5.34 & 4.15E-06 & $1.85 \mathrm{E}-05$ & $8.24 \mathrm{E}-05$ & $1.13 \mathrm{E}-04$ \\
\hline Sr-90 & 12.4 & $9.50 \mathrm{E}+03$ & $1.31 \mathrm{E}+06$ & 12.1 & 12.3 & 12.5 & 12.6 \\
\hline$Y-90$ & 12.4 & $9.51 \mathrm{E}+03$ & $1.31 \mathrm{E}+06$ & 12.1 & 12.3 & 12.5 & 12.6 \\
\hline Zr-93 & $2.11 \mathrm{E}-04$ & 0.163 & 22.4 & $1.86 \mathrm{E}-05$ & 5.17E-05 & $3.71 \mathrm{E}-04$ & $5.24 \mathrm{E}-04$ \\
\hline $\mathrm{Nb}-93 \mathrm{~m}$ & $1.92 \mathrm{E}-04$ & 0.148 & 20.3 & $1.57 \mathrm{E}-05$ & $8.02 \mathrm{E}-05$ & 3.04E-04 & $4.11 \mathrm{E}-04$ \\
\hline Tc-99 & $7.83 \mathrm{E}-05$ & $6.02 \mathrm{E}-02$ & 8.29 & 7.69E-05 & $7.76 \mathrm{E}-05$ & 7.90E-05 & $7.96 \mathrm{E}-05$ \\
\hline $\mathrm{Ru}-106$ & $1.25 \mathrm{E}-08$ & 9.63E-06 & $1.33 \mathrm{E}-03$ & 4.06E-09 & $4.15 \mathrm{E}-09$ & 7.05E-08 & $1.26 \mathrm{E}-07$ \\
\hline Cd- $113 \mathrm{~m}$ & $1.44 \mathrm{E}-04$ & 0.111 & 15.3 & $5.00 \mathrm{E}-05$ & $5.11 \mathrm{E}-05$ & $1.04 \mathrm{E}-03$ & $1.96 \mathrm{E}-03$ \\
\hline$S b-125$ & 4.15E-05 & $3.19 \mathrm{E}-02$ & 4.39 & $4.11 \mathrm{E}-05$ & 4.13E-05 & 4.17E- 05 & $4.21 \mathrm{E}-05$ \\
\hline $\mathrm{Sn}-126$ & $8.22 \mathrm{E}-05$ & $6.32 \mathrm{E}-02$ & 8.71 & $6.58 \mathrm{E}-06$ & $3.43 \mathrm{E}-05$ & $1.30 \mathrm{E}-04$ & $1.76 \mathrm{E}-04$ \\
\hline $\mathrm{L}-129$ & $1.51 \mathrm{E}-07$ & $1.16 \mathrm{E}-04$ & $1.60 \mathrm{E}-02$ & 1.49E-07 & $1.50 \mathrm{E}-07$ & $1.53 \mathrm{E}-07$ & $1.54 \mathrm{E}-07$ \\
\hline Cs-134 & $1.88 \mathrm{E}-06$ & $1.45 \mathrm{E}-03$ & 0.200 & $1.87 \mathrm{E}-06$ & $1.87 \mathrm{E}-06$ & $1.89 \mathrm{E}-06$ & $1.91 \mathrm{E}-06$ \\
\hline Cs- 137 & 0.261 & 201 & $2.77 \mathrm{E}+04$ & 0.257 & 0.259 & 0.264 & 0.266 \\
\hline $\mathrm{Ba}-137 \mathrm{~m}$ & 0.247 & 190 & $2.62 \mathrm{E}+04$ & 0.243 & 0.245 & 0.249 & 0.251 \\
\hline $\mathrm{Sm}-151$ & 0.193 & 149 & $2.05 \mathrm{E}+04$ & $1.53 \mathrm{E}-02$ & $8.18 \mathrm{E}-02$ & 0.305 & 0.413 \\
\hline Eu-152 & $7.41 \mathrm{E}-05$ & $5.70 \mathrm{E}-02$ & 7.85 & $7.41 \mathrm{E}-05$ & $7.41 \mathrm{E}-05$ & $7.41 \mathrm{E}-05$ & $7.41 \mathrm{E}-05$ \\
\hline Eu-154 & $2.39 \mathrm{E}-04$ & 0.184 & 25.3 & $2.26 \mathrm{E}-04$ & $2.30 \mathrm{E}-04$ & $2.48 \mathrm{E}-04$ & $6.21 \mathrm{E}-03$ \\
\hline Eu-155 & $4.84 \mathrm{E}-03$ & 3.73 & 513 & 4.84E- 03 & $4.85 \mathrm{E}-03$ & $4.85 \mathrm{E}-03$ & $4.85 \mathrm{E}-03$ \\
\hline $\mathrm{Ra}-226$ & 7.22E-09 & $5.55 \mathrm{E}-06$ & $7.65 \mathrm{E}-04$ & $5.28 \mathrm{E}-09$ & $6.23 \mathrm{E}-09$ & $8.21 \mathrm{E}-09$ & 9.16E-09 \\
\hline $\mathrm{Ra}-228$ & $8.00 \mathrm{E}-10$ & $6.16 \mathrm{E}-07$ & $8.48 \mathrm{E}-05$ & $8.00 \mathrm{E}-10$ & $8.00 \mathrm{E}-10$ & $8.01 \mathrm{E}-10$ & $8.01 \mathrm{E}-10$ \\
\hline$A c-227$ & $3.76 \mathrm{E}-08$ & $2.89 \mathrm{E}-05$ & $3.99 \mathrm{E}-03$ & $2.66 \mathrm{E}-08$ & $3.20 \mathrm{E}-08$ & $4.32 \mathrm{E}-08$ & $4.86 \mathrm{E}-08$ \\
\hline $\mathrm{Pa}-231$ & 5.17E-08 & $3.98 \mathrm{E}-05$ & $5.48 \mathrm{E}-03$ & $4.50 \mathrm{E}-09$ & $2.06 \mathrm{E}-08$ & $8.29 \mathrm{E}-08$ & $1.13 \mathrm{E}-07$ \\
\hline Th-229 & $3.71 \mathrm{E}-10$ & $2.85 \mathrm{E}-07$ & 3.93E-05 & $3.71 \mathrm{E}-10$ & $3.71 \mathrm{E}-10$ & $3.71 \mathrm{E}-10$ & $3.71 \mathrm{E}-10$ \\
\hline Th-232 & $8.63 \mathrm{E}-11$ & $6.64 \mathrm{E}-08$ & $9.15 \mathrm{E}-06$ & $8.55 \mathrm{E}-11$ & $8.59 \mathrm{E}-11$ & $8.68 \mathrm{E}-11$ & $8.76 \mathrm{E}-11$ \\
\hline $\mathrm{U}-232$ & $5.07 \mathrm{E}-08$ & $3.90 \mathrm{E}-05$ & $5.37 \mathrm{E}-03$ & $4.56 \mathrm{E}-08$ & $4.81 \mathrm{E}-08$ & $5.33 \mathrm{E}-08$ & $5.58 \mathrm{E}-08$ \\
\hline $\mathrm{U}-233$ & $1.96 \mathrm{E}-07$ & $1.51 \mathrm{E}-04$ & $2.08 \mathrm{E}-02$ & $1.77 \mathrm{E}-07$ & $1.86 \mathrm{E}-07$ & $2.06 \mathrm{E}-07$ & $2.16 \mathrm{E}-07$ \\
\hline U-234 & $1.58 \mathrm{E}-07$ & $1.21 \mathrm{E}-04$ & $1.67 \mathrm{E}-02$ & $1.46 \mathrm{E}-07$ & $1.52 \mathrm{E}-07$ & $1.64 \mathrm{E}-07$ & $1.70 \mathrm{E}-07$ \\
\hline U-235 & $6.53 \mathrm{E}-09$ & $5.03 \mathrm{E}-06$ & $6.92 \mathrm{E}-04$ & $6.06 \mathrm{E}-09$ & $6.29 \mathrm{E}-09$ & $6.78 \mathrm{E}-09$ & 7.02E-09 \\
\hline U-236 & $4.32 \mathrm{E}-09$ & $3.32 \mathrm{E}-06$ & $4.58 \mathrm{E}-04$ & $3.98 \mathrm{E}-09$ & $4.15 \mathrm{E}-09$ & $4.50 \mathrm{E}-09$ & $4.66 \mathrm{E}-09$ \\
\hline $\mathrm{U}-238$ & $1.52 \mathrm{E}-07$ & $1.17 \mathrm{E}-04$ & $1.61 \mathrm{E}-02$ & $1.41 \mathrm{E}-07$ & $1.47 \mathrm{E}-07$ & $1.58 \mathrm{E}-07$ & $1.63 \mathrm{E}-07$ \\
\hline $\mathrm{Nn}-237$ & $2.48 \mathrm{E}-07$ & $1.90 \mathrm{E}-04$ & $2.62 \mathrm{E}-02$ & $2.42 \mathrm{E}-07$ & $2.45 \mathrm{E}-07$ & $2.50 \mathrm{E}-07$ & $2.53 \mathrm{E}-07$ \\
\hline $\mathrm{Pu}-238$ & $2.78 \mathrm{E}-06$ & $2.14 \mathrm{E}-03$ & 0.295 & $2.54 \mathrm{E}-06$ & $2.70 \mathrm{E}-06$ & $2.86 \mathrm{E}-06$ & $2.93 \mathrm{E}-06$ \\
\hline $\mathrm{P}_{\mathrm{u}-239}$ & $1.47 \mathrm{E}-04$ & 0.113 & 15.6 & $1.32 \mathrm{E}-04$ & $1.42 \mathrm{E}-04$ & $1.53 \mathrm{E}-04$ & $1.57 \mathrm{E}-04$ \\
\hline $\mathrm{Pu}-240$ & $2.30 \mathrm{E}-05$ & $1.77 \mathrm{E}-02$ & 2.44 & $2.07 \mathrm{E}-05$ & $2.22 \mathrm{E}-05$ & $2.38 \mathrm{E}-05$ & $2.45 \mathrm{E}-05$ \\
\hline $\mathrm{Pu}-241$ & $2.03 \mathrm{E}-04$ & 0.156 & 21.5 & $1.85 \mathrm{E}-04$ & $1.97 \mathrm{E}-04$ & $2.09 \mathrm{E}-04$ & $2.14 \mathrm{E}-04$ \\
\hline $\mathrm{Pu}-242$ & $8.83 \mathrm{E}-10$ & $6.79 \mathrm{E}-07$ & $9.36 \mathrm{E}-05$ & $8.18 \mathrm{E}-10$ & $8.62 \mathrm{E}-10$ & $9.05 \mathrm{E}-10$ & $9.25 \mathrm{E}-10$ \\
\hline$\Delta \mathrm{m}-241$ & $1.65 \mathrm{E}-03$ & 1.27 & 175 & 7.13E-04 & $1.17 \mathrm{E}-03$ & $2.13 \mathrm{E}-03$ & $2.59 \mathrm{E}-03$ \\
\hline$\Delta \mathrm{m}-243$ & $3.59 \mathrm{E}-08$ & $2.76 \mathrm{E}-05$ & $3.80 \mathrm{E}-03$ & $1.61 \mathrm{E}-08$ & $2.60 \mathrm{E}-08$ & $4.54 \mathrm{E}-08$ & $5.41 \mathrm{E}-08$ \\
\hline $\mathrm{Cm}-242$ & $1.76 \mathrm{E}-06$ & $1.35 \mathrm{E}-03$ & 0.187 & $1.76 \mathrm{E}-06$ & $1.76 \mathrm{E}-06$ & $1.76 \mathrm{E}-06$ & $1.76 \mathrm{E}-06$ \\
\hline $\mathrm{Cm}-243$ & $9.74 \mathrm{E}-08$ & $7.50 \mathrm{E}-05$ & $1.03 \mathrm{E}-02$ & $9.75 \mathrm{E}-08$ & $9.75 \mathrm{E}-08$ & $9.75 \mathrm{E}-08$ & $9.75 \mathrm{E}-08$ \\
\hline $\mathrm{Cm}-244$ & $7.60 \mathrm{E}-07$ & $5.85 \mathrm{E}-04$ & $8.06 \mathrm{E}-02$ & $9.50 \mathrm{E}-08$ & $9.67 \mathrm{E}-08$ & $1.92 \mathrm{E}-06$ & $3.04 \mathrm{E}-06$ \\
\hline Totals & $\mathbf{M}$ & עolo & $\mathrm{kg}$ & $\begin{array}{c}-95 \text { CI } \\
\text { M_ar } \alpha / L\end{array}$ & $\begin{array}{c}-67 \mathrm{CI} \\
\mathrm{M} / \mathrm{a} / \mathrm{L} / \mathrm{L} \\
\end{array}$ & $\begin{array}{c}+67 \mathrm{CI} \\
(\mathrm{M} / \mathrm{a} / \mathrm{L} / \mathrm{L} \\
\end{array}$ & $\begin{array}{c}+95 \text { CI } \\
\text { M_ar } \alpha / L / L\end{array}$ \\
\hline $\mathrm{Pu}$ & $1.50 \mathrm{E}-03(\mathrm{~g} / \mathrm{L})$ & --- & 0.158 & $1.23 \mathrm{E}-03$ & $1.41 \mathrm{E}-03$ & $1.58 \mathrm{E}-03$ & $1.66 \mathrm{E}-03$ \\
\hline $\mathrm{U}$ & $1.91 \mathrm{E}-03$ & 350 & 48.3 & $1.78 \mathrm{E}-03$ & $1.84 \mathrm{E}-03$ & $1.99 \mathrm{E}-03$ & $2.06 \mathrm{E}-03$ \\
\hline
\end{tabular}

*Unknowns in tank solids inventory are assigned by Tank Layering Model (TLM).

$\nmid$ Volume average for density, mass average Water wt $\%$ and TOC wt $\% \mathrm{C}$. 
HDW Model Rev. 4

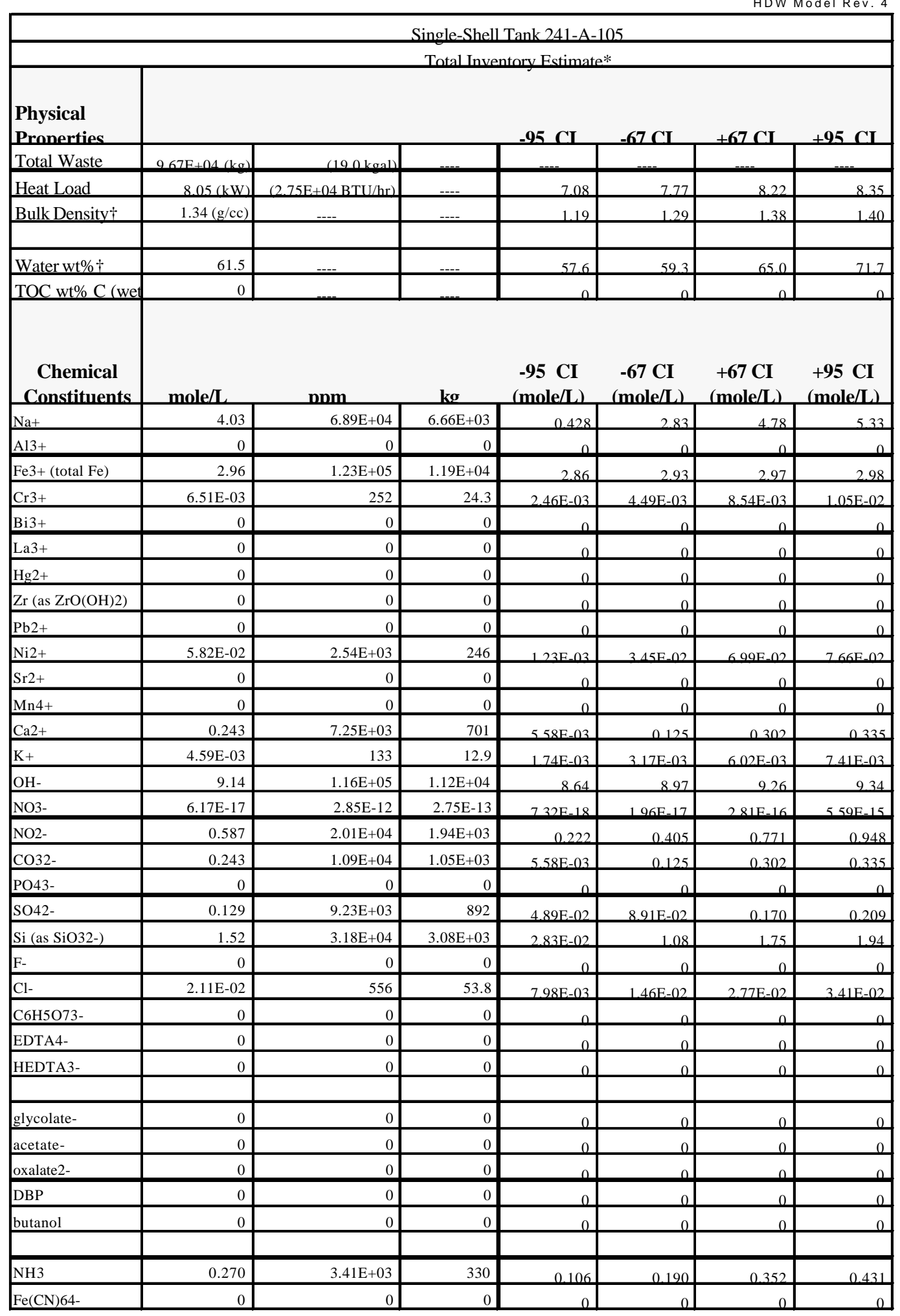

*Unknowns in tank solids inventory are assigned by Tank Layering Model (TLM).

$\dagger$ Water wt $\%$ derived from the difference of density and total dissolved species. 


\begin{tabular}{|c|c|c|c|c|c|c|c|}
\hline \multicolumn{8}{|c|}{ Single-Shell Tank 241-A-105 } \\
\hline & \multicolumn{7}{|c|}{ Total Unventory Estimate* } \\
\hline PhysicalPronerties & & & & $.95 \mathrm{CI}$ & $-67 C L$ & $+67 C I$ & +95 CI \\
\hline Total Waste & $9.67 \mathrm{E}+04(\mathrm{~kg})$ & $(19.0 \mathrm{kgal})$ & $\ldots$ & $\ldots$ & $\ldots$ & $\ldots$ & $\ldots$ \\
\hline Heat Load & $8.05(\mathrm{~kW})$ & $(2.75 \mathrm{E}+04 \mathrm{BTU} / \mathrm{hr})$ & $\ldots$ & 7.08 & 7.77 & 8.22 & 8.35 \\
\hline Bulk Density & $1.34(\mathrm{~g} / \mathrm{cc})$ & $\ldots$ & $\ldots$ & 1.19 & 1.29 & 1.38 & 1.40 \\
\hline Water wt $\% \dagger$ & 61.5 & 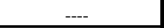 & --- & 57.6 & 59.3 & 65.0 & 71.7 \\
\hline TOC wt $\% \mathrm{C}$ (wet)t & 0 & $\ldots$ & $\ldots$ & 0 & 0 & $\underline{0}$ & 0 \\
\hline $\begin{array}{l}\text { Radiological } \\
\text { Constitwents }\end{array}$ & $\mathrm{Ci} / \mathrm{L}$ & & Ci & $.95 \mathrm{CL}(\mathrm{Ci} / \mathrm{L})$ & $.67 \mathrm{CL}(\mathrm{Ci} / \mathrm{L})$ & $+67 \mathrm{CL}(\mathrm{Ci} / \mathrm{L})$ & $+95 \mathrm{CL}(\mathrm{Ci} / \mathrm{L})$ \\
\hline $\mathrm{H}-3$ & $1.28 \mathrm{E}-04$ & $9.50 \mathrm{E}-02$ & 9.18 & $1.76 \mathrm{E}-05$ & 5.96E-05 & $2.22 \mathrm{E}-04$ & $3.38 \mathrm{E}-04$ \\
\hline C-14 & $2.38 \mathrm{E}-05$ & $1.77 \mathrm{E}-02$ & 1.71 & $9.00 \mathrm{E}-06$ & $1.64 \mathrm{E}-05$ & $3.12 \mathrm{E}-05$ & $3.84 \mathrm{E}-05$ \\
\hline $\mathrm{Ni}-59$ & $1.18 \mathrm{E}-04$ & $8.77 \mathrm{E}-02$ & 8.48 & $2.49 \mathrm{E}-06$ & $7.00 \mathrm{E}-05$ & $1.42 \mathrm{E}-04$ & $1.55 \mathrm{E}-04$ \\
\hline $\mathrm{Ni}-63$ & $1.18 \mathrm{E}-02$ & 8.81 & 852 & $2.50 \mathrm{E}-04$ & $7.03 \mathrm{E}-03$ & $1.42 \mathrm{E}-02$ & $1.56 \mathrm{E}-02$ \\
\hline Co-60 & $3.28 \mathrm{E}-05$ & $2.44 \mathrm{E}-02$ & 2.36 & $1.24 \mathrm{E}-05$ & $2.26 \mathrm{E}-05$ & $4.30 \mathrm{E}-05$ & $3.17 \mathrm{E}-04$ \\
\hline Se-79 & $1.12 \mathrm{E}-04$ & $8.30 \mathrm{E}-02$ & 8.02 & $1.02 \mathrm{E}-05$ & $8.53 \mathrm{E}-05$ & $1.29 \mathrm{E}-04$ & $1.47 \mathrm{E}-04$ \\
\hline Sr-90 & 16.2 & $1.20 \mathrm{E}+04$ & $1.16 \mathrm{E}+06$ & 14.5 & 15.7 & 16.4 & 16.5 \\
\hline $\mathrm{Y}-90$ & 16.2 & $1.20 \mathrm{E}+04$ & $1.16 \mathrm{E}+06$ & 14.5 & 15.7 & 16.4 & 16.5 \\
\hline $7 \mathrm{r}-93$ & 5.12E-04 & 0.381 & 36.8 & $9.11 \mathrm{E}-06$ & $3.81 \mathrm{E}-04$ & $6.02 \mathrm{E}-04$ & $6.87 \mathrm{E}-04$ \\
\hline $\mathrm{Nb}-93 \mathrm{~m}$ & $3.85 \mathrm{E}-04$ & 0.286 & 27.7 & $3.00 \mathrm{E}-05$ & $2.93 \mathrm{E}-04$ & $4.47 \mathrm{E}-04$ & $5.07 \mathrm{E}-04$ \\
\hline Tc-99 & $1.69 \mathrm{E}-04$ & 0.125 & 12.1 & $6.38 \mathrm{E}-05$ & $1.16 \mathrm{E}-04$ & $2.21 \mathrm{E}-04$ & $2.72 \mathrm{E}-04$ \\
\hline Ru-106 & $3.82 \mathrm{E}-07$ & $2.84 \mathrm{E}-04$ & $2.75 \mathrm{E}-02$ & $1.29 \mathrm{E}-07$ & $3.16 \mathrm{E}-07$ & $4.27 \mathrm{E}-07$ & $4.70 \mathrm{E}-07$ \\
\hline Cd-113m & $2.20 \mathrm{E}-03$ & 1.63 & 158 & 4.41E-05 & $1.41 \mathrm{E}-03$ & $2.73 \mathrm{E}-03$ & $3.25 \mathrm{E}-03$ \\
\hline Sb-125 & $1.47 \mathrm{E}-04$ & 0.110 & 10.6 & $5.57 \mathrm{E}-05$ & $1.02 \mathrm{E}-04$ & $1.93 \mathrm{E}-04$ & $2.38 \mathrm{E}-04$ \\
\hline Sn-126 & $1.74 \mathrm{E}-04$ & 0.129 & 12.5 & $2.20 \mathrm{E}-05$ & $1.35 \mathrm{E}-04$ & $2.01 \mathrm{E}-04$ & $2.27 \mathrm{E}-04$ \\
\hline $\mathrm{I}-129$ & $3.26 \mathrm{E}-07$ & $2.43 \mathrm{E}-04$ & $2.35 \mathrm{E}-02$ & $1.23 \mathrm{E}-07$ & $2.25 \mathrm{E}-07$ & $4.28 \mathrm{E}-07$ & 5.27E-07 \\
\hline Cs- 134 & 7.82E-06 & $5.81 \mathrm{E}-03$ & 0.562 & $2.96 \mathrm{E}-06$ & $5.39 \mathrm{E}-06$ & $1.03 \mathrm{E}-05$ & $1.26 \mathrm{E}-05$ \\
\hline Cs-137 & 0.622 & 463 & $4.47 \mathrm{E}+04$ & 0.235 & 0.429 & 0.816 & 1.00 \\
\hline $\mathrm{Ba}-137 \mathrm{~m}$ & 0.588 & 438 & $4.23 \mathrm{E}+04$ & 0.223 & 0.406 & 0.772 & 0.950 \\
\hline $\mathrm{Sm}-151$ & 0.416 & 309 & $2.99 \mathrm{E}+04$ & $6.12 \mathrm{E}-02$ & 0.324 & 0.478 & 0.538 \\
\hline$E_{11-152}$ & $1.27 \mathrm{E}-04$ & $9.44 \mathrm{E}-02$ & 9.13 & $1.25 \mathrm{E}-04$ & $1.26 \mathrm{E}-04$ & $1.28 \mathrm{E}-04$ & $1.29 \mathrm{E}-04$ \\
\hline Eul-154 & 7.32E- 03 & 5.44 & 526 & $2.36 \mathrm{E}-04$ & 7.46E-04 & $1.18 \mathrm{E}-02$ & $1.61 \mathrm{E}-02$ \\
\hline Eu-155 & $9.46 \mathrm{E}-03$ & 7.03 & 680 & $9.28 \mathrm{E}-03$ & $9.37 \mathrm{E}-03$ & $9.55 \mathrm{E}-03$ & $9.64 \mathrm{E}-03$ \\
\hline Ra-226 & $7.40 \mathrm{E}-09$ & $5.51 \mathrm{E}-06$ & $5.32 \mathrm{E}-04$ & $4.26 \mathrm{E}-09$ & $6.59 \mathrm{E}-09$ & $7.96 \mathrm{E}-09$ & $8.49 \mathrm{E}-09$ \\
\hline $\mathrm{Ra}-228$ & $6.69 \mathrm{E}-14$ & $4.98 \mathrm{E}-11$ & $4.81 \mathrm{E}-09$ & $6.57 \mathrm{E}-14$ & $6.63 \mathrm{E}-14$ & $6.76 \mathrm{E}-14$ & $6.82 \mathrm{E}-14$ \\
\hline$A c-227$ & 3.99E-08 & $2.97 \mathrm{E}-05$ & $2.87 \mathrm{E}-03$ & $2.17 \mathrm{E}-08$ & $3.52 \mathrm{E}-08$ & $4.31 \mathrm{E}-08$ & $4.62 \mathrm{E}-08$ \\
\hline $\mathrm{Pa}-231$ & $8.98 \mathrm{E}-08$ & $6.68 \mathrm{E}-05$ & $6.46 \mathrm{E}-03$ & 1.67E-09 & $6.36 \mathrm{E}-08$ & $1.08 \mathrm{E}-07$ & $1.25 \mathrm{E}-07$ \\
\hline Th-229 & $1.04 \mathrm{E}-11$ & $7.77 \mathrm{E}-09$ & $7.51 \mathrm{E}-07$ & $1.03 \mathrm{E}-11$ & $1.04 \mathrm{E}-11$ & $1.06 \mathrm{E}-11$ & $1.06 \mathrm{E}-11$ \\
\hline Th-232 & $6.04 \mathrm{E}-15$ & $4.49 \mathrm{E}-12$ & $4.34 \mathrm{E}-10$ & $2.28 \mathrm{E}-15$ & $4.17 \mathrm{E}-15$ & $7.93 \mathrm{E}-15$ & $9.75 \mathrm{E}-15$ \\
\hline U-232 & $8.40 \mathrm{E}-12$ & $6.24 \mathrm{E}-09$ & $6.04 \mathrm{E}-07$ & $3.18 \mathrm{E}-12$ & $5.79 \mathrm{E}-12$ & $1.10 \mathrm{E}-11$ & $1.36 \mathrm{E}-11$ \\
\hline U-233 & $1.98 \mathrm{E}-13$ & $1.47 \mathrm{E}-10$ & $1.42 \mathrm{E}-08$ & $7.49 \mathrm{E}-14$ & $1.37 \mathrm{E}-13$ & $2.60 \mathrm{E}-13$ & $3.20 \mathrm{E}-13$ \\
\hline U-234 & $1.04 \mathrm{E}-07$ & $7.70 \mathrm{E}-05$ & $7.44 \mathrm{E}-03$ & $3.91 \mathrm{E}-08$ & $7.14 \mathrm{E}-08$ & $1.36 \mathrm{E}-07$ & $1.67 \mathrm{E}-07$ \\
\hline U-235 & $4.32 \mathrm{E}-09$ & $3.21 \mathrm{E}-06$ & $3.10 \mathrm{E}-04$ & 1.63E-09 & $2.98 \mathrm{E}-09$ & $5.67 \mathrm{E}-09$ & $6.97 \mathrm{E}-09$ \\
\hline U-236 & $2.82 \mathrm{E}-09$ & $2.10 \mathrm{E}-06$ & $2.03 \mathrm{E}-04$ & $1.07 \mathrm{E}-09$ & $1.95 \mathrm{E}-09$ & $3.71 \mathrm{E}-09$ & 4.56E- 09 \\
\hline U-238 & $1.01 \mathrm{E}-07$ & $7.49 \mathrm{E}-05$ & $7.25 \mathrm{E}-03$ & $3.81 \mathrm{E}-08$ & $6.95 \mathrm{E}-08$ & $1.32 \mathrm{E}-07$ & $1.63 \mathrm{E}-07$ \\
\hline $\mathrm{Nn}-237$ & $3.60 \mathrm{E}-07$ & $2.68 \mathrm{E}-04$ & $2.59 \mathrm{E}-02$ & $1.36 \mathrm{E}-07$ & $2.49 \mathrm{E}-07$ & 4.73E-07 & 5.82E-07 \\
\hline $\mathrm{Pu}-238$ & $9.43 \mathrm{E}-05$ & $7.01 \mathrm{E}-02$ & 6.78 & $7.72 \mathrm{E}-05$ & $8.99 \mathrm{E}-05$ & $9.73 \mathrm{E}-05$ & $1.00 \mathrm{E}-04$ \\
\hline $\mathrm{Pu}-239$ & $2.44 \mathrm{E}-03$ & 1.82 & 176 & $2.00 \mathrm{E}-03$ & $2.33 \mathrm{E}-03$ & $2.52 \mathrm{E}-03$ & $2.60 \mathrm{E}-03$ \\
\hline $\mathrm{Pu}-240$ & $4.66 \mathrm{E}-04$ & 0.347 & 33.5 & $3.82 \mathrm{E}-04$ & 4.44E- 04 & $4.81 \mathrm{E}-04$ & $4.95 \mathrm{E}-04$ \\
\hline $\mathrm{Pu}-241$ & $6.71 \mathrm{E}-03$ & 4.99 & 483 & $5.50 \mathrm{E}-03$ & $6.40 \mathrm{E}-03$ & $6.93 \mathrm{E}-03$ & 7.13E-03 \\
\hline $\mathrm{Pu}-242$ & $3.88 \mathrm{E}-08$ & $2.89 \mathrm{E}-05$ & $2.79 \mathrm{E}-03$ & $3.18 \mathrm{E}-08$ & $3.70 \mathrm{E}-08$ & $4.01 \mathrm{E}-08$ & $4.12 \mathrm{E}-08$ \\
\hline Am-241 & 3.84E-03 & 2.86 & 276 & $2.32 \mathrm{E}-03$ & $3.45 \mathrm{E}-03$ & $4.11 \mathrm{E}-03$ & $4.37 \mathrm{E}-03$ \\
\hline Am-243 & $1.18 \mathrm{E}-07$ & $8.77 \mathrm{E}-05$ & $8.48 \mathrm{E}-03$ & $7.12 \mathrm{E}-08$ & $1.06 \mathrm{E}-07$ & $1.26 \mathrm{E}-07$ & $1.34 \mathrm{E}-07$ \\
\hline $\mathrm{Cm}-242$ & 3.51E-06 & $2.61 \mathrm{E}-03$ & 0.252 & $3.44 \mathrm{E}-06$ & $3.48 \mathrm{E}-06$ & $3.54 \mathrm{E}-06$ & $3.58 \mathrm{E}-06$ \\
\hline $\mathrm{Cm}-243$ & $2.70 \mathrm{E}-07$ & $2.01 \mathrm{E}-04$ & $1.94 \mathrm{E}-02$ & $2.64 \mathrm{E}-07$ & $2.67 \mathrm{E}-07$ & $2.72 \mathrm{E}-07$ & $2.75 \mathrm{E}-07$ \\
\hline $\mathrm{Cm}-244$ & $8.29 \mathrm{E}-06$ & $6.17 \mathrm{E}-03$ & 0.596 & $3.22 \mathrm{E}-06$ & $6.98 \mathrm{E}-06$ & $9.18 \mathrm{E}-06$ & $1.00 \mathrm{E}-05$ \\
\hline Tatals & $\mathbf{M}$ & & $\mathrm{kg}$ & 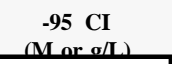 & $\begin{array}{c}-67 \mathrm{CI} \\
\mathrm{M} / \mathrm{ar} \sigma / \mathrm{L}\end{array}$ & $\begin{array}{c}+67 \mathrm{CI} \\
\mathrm{M} / \mathrm{ar} / \mathrm{L} / \mathrm{L}\end{array}$ & $\begin{array}{c}+95 \text { CI } \\
\text { M_ar } 0 / \text { L }\end{array}$ \\
\hline $\mathrm{Pu}$ & $4.14 \mathrm{E}-02(\mathrm{~g} / \mathrm{L})$ & -- & 2.98 & $3.39 \mathrm{E}-02$ & $3.95 \mathrm{E}-02$ & $4.28 \mathrm{E}-02$ & $4.40 \mathrm{E}-02$ \\
\hline $\mathrm{U}$ & $1.27 \mathrm{E}-03$ & 224 & 21.7 & $4.80 \mathrm{E}-04$ & $8.75 \mathrm{E}-04$ & $1.66 \mathrm{E}-03$ & $2.05 \mathrm{E}-03$ \\
\hline
\end{tabular}

*Unknowns in tank solids inventory are assigned by Tank Layering Model (TLM).

$\dagger$ Volume average for density, mass average Water wt $\%$ and TOC wt $\% \mathrm{C}$. 
HDW Model Rev. 4

\begin{tabular}{|c|c|c|c|c|c|c|c|}
\hline & & & ingle-Shell & Tank 241-A- & & & \\
\hline & & & Total Inves & tory Estimat & & & \\
\hline \begin{tabular}{|l} 
Physical \\
Properties
\end{tabular} & & & & .95 CI & $-67 \mathrm{CI}$ & $+67 \mathrm{CI}$ & $+95 \mathrm{CI}$ \\
\hline Total Waste & $7.16 \mathrm{E}+05(\mathrm{~kg})$ & $0125 \mathrm{kgal}$ & & & & & \\
\hline Heat Load & $14.6(\mathrm{~kW})$ & $(4.98 \mathrm{E} \pm 04 \mathrm{BTU} / \mathrm{hr})$ & $\ldots$ & 745 & 121 & 157 & 163 \\
\hline Bulk Density $\dagger$ & $1.51(\mathrm{~g} / \mathrm{cc})$ & & $\ldots$ & 1.44 & 148 & 1.54 & 1.56 \\
\hline & & & & & & & \\
\hline Water wt $\% \dagger$ & 42.3 & & & 389 & 40.4 & 44.4 & 47.5 \\
\hline TOC wt $\% \mathrm{C}$ (wet) & 1.53 & & & م681 & 112 & 103 & 221 \\
\hline $\begin{array}{c}\text { Chemical } \\
\text { Constituents }\end{array}$ & $\mathrm{mole} / \mathrm{L}$ & nnm & kg & $\begin{array}{c}-95 \mathrm{CI} \\
(\mathrm{mole} / \mathrm{L}) \\
\end{array}$ & $\begin{array}{c}-67 \mathrm{CI} \\
(\mathrm{mole} / \mathrm{L})\end{array}$ & $\begin{array}{c}+67 \mathrm{CI} \\
(\mathrm{mole} / \mathrm{L})\end{array}$ & $\begin{array}{r}+95 \mathrm{CI} \\
(\mathrm{mole} / \mathrm{L})\end{array}$ \\
\hline $\mathrm{Na}+$ & 11.4 & $1.74 \mathrm{E}+05$ & $1.24 \mathrm{E}+05$ & 287 & 107 & 119 & 124 \\
\hline $\mathrm{Al} 13+$ & 1.12 & $1.99 \mathrm{E}+04$ & $1.42 \mathrm{E}+04$ & 101 & 1.08 & 115 & 118 \\
\hline $\mathrm{Fe} 3+($ total Fe) & 0.521 & $1.92 \mathrm{E}+04$ & $1.38 \mathrm{E}+04$ & 0290 & 0.476 & 0.541 & 0.552 \\
\hline $\mathrm{Cr} 3+$ & $8.93 \mathrm{E}-02$ & $3.07 \mathrm{E}+03$ & $2.20 \mathrm{E}+03$ & $767 \mathrm{E}-02$ & $8.35 \mathrm{E}-02$ & $916 \mathrm{E}-02$ & $2.45 \mathrm{E}-02$ \\
\hline $\mathrm{Bi} 3+$ & $8.13 \mathrm{E}-04$ & 112 & 80.4 & $7.56 \mathrm{E}-04$ & $784 \mathrm{E}-04$ & $8.42 \mathrm{E}-04$ & $8.70 \mathrm{E}-04$ \\
\hline $\mathrm{La} 3+$ & $1.79 \mathrm{E}-05$ & 1.64 & 1.17 & $131 \mathrm{E}-05$ & $1.54 \mathrm{E}-05$ & $203 \mathrm{E}-05$ & $2.27 \mathrm{E}-0.5$ \\
\hline $\mathrm{Hg} 2+$ & $6.15 \mathrm{E}-06$ & 0.815 & 0.584 & $585 \mathrm{E}-06$ & $602 E-06$ & $623 \mathrm{E}-06$ & $6.30 \mathrm{E}-06$ \\
\hline $\mathrm{Zr}$ (as $\mathrm{ZrO}(\mathrm{OH}) 2)$ & $1.25 \mathrm{E}-04$ & 7.54 & 5.40 & 1 1 $15 \mathrm{E}-\mathrm{OA}$ & 1 1 $18 E_{-}-04$ & $120 \mathrm{E}-\mathrm{OA}$ & $135 \mathrm{E}-\mathrm{C}$ \\
\hline $\mathrm{Pb} 2+$ & $7.70 \mathrm{E}-04$ & 105 & 75.5 & $6.57 \mathrm{E}-\mathrm{NA}$ & 7 13E_-OA & 828E-OA & $883 E_{-} 0$ \\
\hline $\mathrm{Ni} 2+$ & $2.71 \mathrm{E}-02$ & $1.05 \mathrm{E}+03$ & 753 & $269 \mathrm{E}-02$ & $270 \mathrm{E}-02$ & $272 \mathrm{E}-02$ & $272 \mathrm{E}-02$ \\
\hline $\mathrm{Sr} 2+$ & 0 & 0 & 0 & & & 0 & \\
\hline Mn4+ & $3.14 \mathrm{E}-03$ & 114 & 81.6 & $2.65 \mathrm{E}-03$ & $289 \mathrm{E}-03$ & $3.39 \mathrm{E}-03$ & $3.63 \mathrm{E}-03$ \\
\hline $\mathrm{Ca} 2+$ & $7.02 \mathrm{E}-02$ & $1.86 \mathrm{E}+03$ & $1.33 \mathrm{E}+03$ & $3.86 \mathrm{E}-02$ & $3.99 \mathrm{E}-02$ & $928 \mathrm{E}-02$ & 0105 \\
\hline $\mathrm{K}+$ & $4.61 \mathrm{E}-02$ & $1.19 \mathrm{E}+03$ & 852 & $426 \mathrm{E}-02$ & $4.41 \mathrm{E}-02$ & $4.84 \mathrm{E}-02$ & $5.16 \mathrm{E}-02$ \\
\hline $\mathrm{OH}-$ & 8.07 & $9.06 \mathrm{E}+04$ & $6.49 \mathrm{E}+04$ & 7.34 & 787 & 828 & 8.38 \\
\hline NO3- & 2.98 & $1.22 \mathrm{E}+05$ & $8.75 \mathrm{E}+04$ & 2.80 & 2.91 & 3.02 & 3.06 \\
\hline $\mathrm{NO} 2-$ & 1.85 & $5.62 \mathrm{E}+04$ & $4.02 \mathrm{E}+04$ & 1.64 & 1.74 & 1.96 & 2.06 \\
\hline $\mathrm{CO} 32-$ & 0.423 & $1.68 \mathrm{E}+04$ & $1.20 \mathrm{E}+04$ & 0340 & 0368 & 0471 & مـ574 \\
\hline PO43- & $6.14 \mathrm{E}-02$ & $3.85 \mathrm{E}+03$ & $2.76 \mathrm{E}+03$ & $553 \mathrm{E}-02$ & $574 \mathrm{E}-02$ & $635 \mathrm{E}-02$ & $663 \mathrm{E}-0$ \\
\hline SO42- & 0.204 & $1.29 \mathrm{E}+04$ & $9.25 \mathrm{E}+03$ & 0.176 & 0189 & 0218 & 0231 \\
\hline $\mathrm{Si}$ (as $\mathrm{SiO} 32-$ ) & 0.849 & $1.58 \mathrm{E}+04$ & $1.13 \mathrm{E}+04$ & 0434 & م6565 & مـ 934 & م-994 \\
\hline $\mathrm{F}-$ & $4.22 \mathrm{E}-02$ & 530 & 379 & $372 \mathrm{E}-02$ & $303 \mathrm{E}-02$ & $4.46 \mathrm{E}-02$ & $4.82 \mathrm{E}-02$ \\
\hline $\mathrm{Cl}-$ & 0.170 & $3.98 \mathrm{E}+03$ & $2.85 \mathrm{E}+03$ & 0.157 & 0.164 & 0.177 & 0.182 \\
\hline C6H5O73- & $1.97 \mathrm{E}-02$ & $2.46 \mathrm{E}+03$ & $1.76 \mathrm{E}+03$ & $1.83 \mathrm{E}-02$ & $1.90 \mathrm{E}-02$ & $2.05 \mathrm{E}-02$ & $2.14 \mathrm{E}-02$ \\
\hline EDTA4- & $4.60 \mathrm{E}-02$ & $8.75 \mathrm{E}+03$ & $6.27 \mathrm{E}+03$ & $1.33 \mathrm{E}-02$ & $3.01 \mathrm{E}-02$ & $6.18 \mathrm{E}-02$ & $7.37 \mathrm{E}-02$ \\
\hline HEDTA3- & $8.89 \mathrm{E}-02$ & $1.61 \mathrm{E}+04$ & $1.15 \mathrm{E}+04$ & $2.35 \mathrm{E}-02$ & $570 \mathrm{E}-02$ & 0.120 & 0.144 \\
\hline & & & & & & & \\
\hline glycolate- & 0.130 & $6.42 \mathrm{E}+03$ & $4.60 \mathrm{E}+03$ & $6.42 \mathrm{E}-02$ & $276 \mathrm{E}-02$ & 0.161 & 0.185 \\
\hline acetate- & $1.01 \mathrm{E}-02$ & 393 & 281 & $831 \mathrm{E}-03$ & $907 E-03$ & $112 \mathrm{E}-02$ & $128 \mathrm{E}-02$ \\
\hline oxalate2- & $2.34 \mathrm{E}-05$ & 1.36 & 0.975 & $208 \mathrm{E}-05$ & $221 \mathrm{E}-05$ & $247 \mathrm{E}-05$ & $260 \mathrm{E}-05$ \\
\hline DBP & $1.52 \mathrm{E}-02$ & $2.11 \mathrm{E}+03$ & $1.51 \mathrm{E}+03$ & $135 \mathrm{E}-02$ & $143 E_{-}-02$ & $162 \mathrm{E}-02$ & $177 \mathrm{E}-02$ \\
\hline butanol & $1.52 \mathrm{E}-02$ & 744 & 533 & $135 \mathrm{E}-\mathrm{O} 2$ & $143 \mathrm{E}-02$ & $162 \mathrm{E}-\mathrm{O} 2$ & $177 \mathrm{E}-0$ \\
\hline & & & & & & & \\
\hline $\mathrm{NH} 3$ & 0.111 & $1.25 \mathrm{E}+03$ & 893 & $796 \mathrm{E}-02$ & $2,47 \mathrm{E}-02$ & 0.126 & 0.132 \\
\hline $\mathrm{Fe}(\mathrm{CN}) 64-$ & 0 & 0 & 0 & 0 & 0 & 0 & \\
\hline
\end{tabular}

*Unknowns in tank solids inventory are assigned by Tank Layering Model (TLM).

$\dagger$ Water wt $\%$ derived from the difference of density and total dissolved species. 
HDW Model Rev. 4

\begin{tabular}{|c|c|c|c|c|c|c|c|}
\hline \multicolumn{8}{|c|}{ Single-Shell Tank 241-A-106 } \\
\hline \multicolumn{8}{|c|}{ Total Inventory Estimate* } \\
\hline $\begin{array}{l}\text { Physical } \\
\text { Pronerties }\end{array}$ & & & & $.05 \mathrm{CI}$ & $-67 \mathrm{CL}$ & $+67 \mathrm{CI}$ & $+05 \mathrm{CI}$ \\
\hline Total Waste & $7.16 \mathrm{E}+05(\mathrm{~kg})$ & $(125 \mathrm{kgal})$ & $-\cdots$ & $\ldots$ & $\ldots$ & $\ldots$ & $-\cdots$ \\
\hline Heat Load & $14.6(\mathrm{~kW})$ & $(4.98 \mathrm{E}+04 \mathrm{BTU} / \mathrm{hr})$ & $-\ldots$ & 7.45 & 12.1 & 15.7 & 16.3 \\
\hline Bulk Density & $1.51(\mathrm{~g} / \mathrm{cc})$ & $\ldots$ & $\ldots$ & 1.44 & 1.48 & 1.54 & 1.56 \\
\hline Water wt $\% \div$ & 42.3 & -..- & $\ldots$ & 38.9 & 40.4 & 44.4 & 47.5 \\
\hline TOC wt $\% \mathrm{C}$ (wet & 1.53 & $-\cdots$ & $-\ldots$ & 0.681 & 1.12 & 1.93 & 2.21 \\
\hline $\begin{array}{l}\text { Radiological } \\
\text { Conctitunntc }\end{array}$ & (I/I & م/:عس & $\mathbf{C i}$ & O5_LI $/(\mathrm{Ci} / \mathrm{L})$ & (6) & 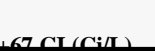 & 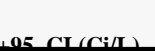 \\
\hline $\mathrm{H}-3$ & $1.83 \mathrm{E}-04$ & 0.121 & 86.5 & 1.20E-04 & $1.20 \mathrm{E}-04$ & $2.08 \mathrm{E}-04$ & 2.35E-04 \\
\hline C-14 & $2.80 \mathrm{E}-05$ & $1.85 \mathrm{E}-02$ & 13.2 & $1.49 \mathrm{E}-05$ & $1.49 \mathrm{E}-05$ & $2.88 \mathrm{E}-05$ & $3.63 \mathrm{E}-05$ \\
\hline $\mathrm{Ni}-59$ & $1.62 \mathrm{E}-04$ & 0.107 & 76.5 & $1.51 \mathrm{E}-04$ & $1.56 \mathrm{E}-04$ & $1.67 \mathrm{E}-04$ & $1.72 \mathrm{E}-04$ \\
\hline Ni-63 & $1.59 \mathrm{E}-02$ & 10.5 & $7.53 \mathrm{E}+03$ & $1.49 \mathrm{E}-02$ & $1.54 \mathrm{E}-02$ & $1.64 \mathrm{E}-02$ & $1.69 \mathrm{E}-02$ \\
\hline Co-60 & $3.45 \mathrm{E}-05$ & $2.28 \mathrm{E}-02$ & 16.3 & $1.95 \mathrm{E}-05$ & $1.95 \mathrm{E}-05$ & $3.62 \mathrm{E}-05$ & $4.38 \mathrm{E}-05$ \\
\hline Se-79 & $8.97 \mathrm{E}-05$ & $5.93 \mathrm{E}-02$ & 42.5 & $2.63 \mathrm{E}-05$ & $5.06 \mathrm{E}-05$ & $1.29 \mathrm{E}-04$ & $1.66 \mathrm{E}-04$ \\
\hline Sr-90 & 4.38 & $2.89 \mathrm{E}+03$ & $2.07 \mathrm{E}+06$ & 2.18 & 3.60 & 4.72 & 4.91 \\
\hline Y-90 & 4.38 & $2.89 \mathrm{E}+03$ & $2.07 \mathrm{E}+06$ & 2.18 & 3.61 & 4.72 & 4.91 \\
\hline Zr-93 & $3.88 \mathrm{E}-04$ & 0.256 & 184 & $9.90 \mathrm{E}-05$ & $1.93 \mathrm{E}-04$ & $5.84 \mathrm{E}-04$ & $7.71 \mathrm{E}-04$ \\
\hline $\mathrm{Nb}-93 \mathrm{~m}$ & 3.33E-04 & 0.220 & 158 & $9.01 \mathrm{E}-05$ & $1.96 \mathrm{E}-04$ & $4.70 \mathrm{E}-04$ & $6.01 \mathrm{E}-04$ \\
\hline$T c-99$ & $2.05 \mathrm{E}-04$ & 0.136 & 97.1 & $1.56 \mathrm{E}-04$ & $1.80 \mathrm{E}-04$ & $2.30 \mathrm{E}-04$ & $2.55 \mathrm{E}-04$ \\
\hline Ru-106 & $6.17 \mathrm{E}-07$ & 4.07E-04 & 0.292 & 4.72E-07 & $5.82 \mathrm{E}-07$ & $6.51 \mathrm{E}-07$ & $6.85 \mathrm{E}-07$ \\
\hline Cd- $113 \mathrm{~m}$ & $8.16 \mathrm{E}-04$ & 0.539 & 386 & $9.45 \mathrm{E}-05$ & $3.99 \mathrm{E}-04$ & $1.81 \mathrm{E}-03$ & $2.94 \mathrm{E}-03$ \\
\hline Sh-125 & $1.56 \mathrm{E}-04$ & 0.103 & 73.6 & $9.06 \mathrm{E}-05$ & $9.06 \mathrm{E}-05$ & $1.66 \mathrm{E}-04$ & $1.73 \mathrm{E}-04$ \\
\hline $\mathrm{Sn}-126$ & $1.44 \mathrm{E}-04$ & $9.53 \mathrm{E}-02$ & 68.3 & $4.38 \mathrm{E}-05$ & $8.56 \mathrm{E}-05$ & $2.03 \mathrm{E}-04$ & $2.59 \mathrm{E}-04$ \\
\hline I-129 & $3.96 \mathrm{E}-07$ & $2.62 \mathrm{E}-04$ & 0.188 & $3.02 \mathrm{E}-07$ & $3.48 \mathrm{E}-07$ & $4.45 \mathrm{E}-07$ & $4.92 \mathrm{E}-07$ \\
\hline Cs-134 & $4.91 \mathrm{E}-06$ & $3.24 \mathrm{E}-03$ & 2.32 & $2.44 \mathrm{E}-06$ & $3.70 \mathrm{E}-06$ & $6.10 \mathrm{E}-06$ & $7.01 \mathrm{E}-06$ \\
\hline Cs-137 & 0.277 & 183 & $1.31 \mathrm{E}+05$ & 0.232 & 0.255 & 0.299 & 0.315 \\
\hline Ba-137m & 0.262 & 173 & $1.24 \mathrm{E}+05$ & 0.220 & 0.233 & 0.283 & 0.298 \\
\hline $\mathrm{Sm}-151$ & 0.336 & 222 & $1.59 \mathrm{E}+05$ & 0.104 & 0.199 & 0.473 & 0.604 \\
\hline $\mathrm{Eu}-152$ & $8.92 \mathrm{E}-05$ & $5.89 \mathrm{E}-02$ & 42.2 & $8.74 \mathrm{E}-05$ & $8.81 \mathrm{E}-05$ & $9.00 \mathrm{E}-05$ & $9.07 \mathrm{E}-05$ \\
\hline En-154 & $2.24 \mathrm{E}-03$ & 1.48 & $1.06 \mathrm{E}+03$ & $5.10 \mathrm{E}-04$ & $5.86 \mathrm{E}-04$ & $5.71 \mathrm{E}-03$ & $1.17 \mathrm{E}-02$ \\
\hline Eul-155 & $5.52 \mathrm{E}-03$ & 3.65 & $2.61 \mathrm{E}+03$ & $5.41 \mathrm{E}-03$ & $5.46 \mathrm{E}-03$ & $5.57 \mathrm{E}-03$ & $5.61 \mathrm{E}-03$ \\
\hline Ra-226 & $1.08 \mathrm{E}-08$ & $7.14 \mathrm{E}-06$ & $5.11 \mathrm{E}-03$ & $8.43 \mathrm{E}-09$ & $9.59 \mathrm{E}-09$ & $1.20 \mathrm{E}-08$ & $1.32 \mathrm{E}-08$ \\
\hline Ra-228 & $1.77 \mathrm{E}-07$ & $1.17 \mathrm{E}-04$ & $8.39 \mathrm{E}-02$ & $7.56 \mathrm{E}-08$ & $7.56 \mathrm{E}-08$ & $2.04 \mathrm{E}-07$ & $2.33 \mathrm{E}-07$ \\
\hline$A c-227$ & $5.61 \mathrm{E}-08$ & $3.70 \mathrm{E}-05$ & $2.65 \mathrm{E}-02$ & 4.23E-08 & $4.91 \mathrm{E}-08$ & $6.31 \mathrm{E}-08$ & $6.99 \mathrm{E}-08$ \\
\hline $\mathrm{Pa}-231$ & $8.51 \mathrm{E}-08$ & $5.62 \mathrm{E}-05$ & $4.02 \mathrm{E}-02$ & $1.38 \mathrm{E}-08$ & $4.60 \mathrm{E}-08$ & $1.24 \mathrm{E}-07$ & $1.62 \mathrm{E}-07$ \\
\hline Th-229 & $4.19 \mathrm{E}-09$ & $2.77 \mathrm{E}-06$ & $1.98 \mathrm{E}-03$ & $1.84 \mathrm{E}-09$ & $1.84 \mathrm{E}-09$ & $4.78 \mathrm{E}-09$ & $5.41 \mathrm{E}-09$ \\
\hline Th-232 & $1.75 \mathrm{E}-08$ & $1.15 \mathrm{E}-05$ & $8.27 \mathrm{E}-03$ & $4.89 \mathrm{E}-09$ & $4.89 \mathrm{E}-09$ & $2.09 \mathrm{E}-08$ & $2.42 \mathrm{E}-08$ \\
\hline U-232 & $6.27 \mathrm{E}-07$ & $4.14 \mathrm{E}-04$ & 0.297 & 4.45E-07 & $5.34 \mathrm{E}-07$ & $7.35 \mathrm{E}-07$ & $8.50 \mathrm{E}-07$ \\
\hline U-233 & $2.40 \mathrm{E}-06$ & $1.59 \mathrm{E}-03$ & 1.14 & $1.71 \mathrm{E}-06$ & $2.05 \mathrm{E}-06$ & $2.82 \mathrm{E}-06$ & $3.26 \mathrm{E}-06$ \\
\hline U-234 & $5.49 \mathrm{E}-07$ & $3.63 \mathrm{E}-04$ & 0.260 & $5.32 \mathrm{E}-07$ & $5.41 \mathrm{E}-07$ & $5.58 \mathrm{E}-07$ & $5.63 \mathrm{E}-07$ \\
\hline U-235 & $2.21 \mathrm{E}-08$ & $1.46 \mathrm{E}-05$ & $1.04 \mathrm{E}-02$ & $2.14 \mathrm{E}-08$ & $2.17 \mathrm{E}-08$ & $2.25 \mathrm{E}-08$ & $2.27 \mathrm{E}-08$ \\
\hline U-236 & $1.75 \mathrm{E}-08$ & $1.16 \mathrm{E}-05$ & $8.30 \mathrm{E}-03$ & $1.70 \mathrm{E}-08$ & $1.73 \mathrm{E}-08$ & $1.78 \mathrm{E}-08$ & $1.80 \mathrm{E}-08$ \\
\hline U-238 & $6.83 \mathrm{E}-07$ & $4.51 \mathrm{E}-04$ & 0.323 & $6.66 \mathrm{E}-07$ & $6.74 \mathrm{E}-07$ & $6.92 \mathrm{E}-07$ & $6.99 \mathrm{E}-07$ \\
\hline $\mathrm{Nn}-237$ & $7.20 \mathrm{E}-07$ & $4.76 \mathrm{E}-04$ & 0.341 & $5.60 \mathrm{E}-07$ & $6.38 \mathrm{E}-07$ & $8.03 \mathrm{E}-07$ & $8.82 \mathrm{E}-07$ \\
\hline $\mathrm{Pu}-238$ & $1.12 \mathrm{E}-04$ & $7.38 \mathrm{E}-02$ & 52.9 & 7.41E-05 & $1.04 \mathrm{E}-04$ & $1.19 \mathrm{E}-04$ & $1.26 \mathrm{E}-04$ \\
\hline$P_{u-239}$ & $3.01 \mathrm{E}-03$ & 1.99 & $1.42 \mathrm{E}+03$ & $2.00 \mathrm{E}-03$ & $2.76 \mathrm{E}-03$ & $3.27 \mathrm{E}-03$ & $3.51 \mathrm{E}-03$ \\
\hline $\mathrm{Pu}-240$ & $5.59 \mathrm{E}-04$ & 0.369 & 264 & $3.71 \mathrm{E}-04$ & $5.15 \mathrm{E}-04$ & $6.02 \mathrm{E}-04$ & $6.44 \mathrm{E}-04$ \\
\hline $\mathrm{Pu}-241$ & 7.92E-03 & 5.23 & $3.75 \mathrm{E}+03$ & $5.25 \mathrm{E}-03$ & $7.40 \mathrm{E}-03$ & $8.44 \mathrm{E}-03$ & $8.92 \mathrm{E}-03$ \\
\hline $\mathrm{Pu}-242$ & 4.67E- 08 & $3.08 \mathrm{E}-05$ & $2.21 \mathrm{E}-02$ & $3.09 \mathrm{E}-08$ & $4.36 \mathrm{E}-08$ & $4.94 \mathrm{E}-08$ & $5.20 \mathrm{E}-08$ \\
\hline$A m-241$ & $3.66 \mathrm{E}-03$ & 2.42 & $1.73 \mathrm{E}+03$ & $2.51 \mathrm{E}-03$ & $3.08 \mathrm{E}-03$ & $4.25 \mathrm{E}-03$ & $4.81 \mathrm{E}-03$ \\
\hline$\Delta \mathrm{m}-243$ & $1.83 \mathrm{E}-07$ & $1.21 \mathrm{E}-04$ & $8.65 \mathrm{E}-02$ & $1.37 \mathrm{E}-07$ & $1.68 \mathrm{E}-07$ & $1.96 \mathrm{E}-07$ & $2.07 \mathrm{E}-07$ \\
\hline $\mathrm{Cm}-242$ & $3.21 \mathrm{E}-06$ & $2.12 \mathrm{E}-03$ & 1.52 & $3.14 \mathrm{E}-06$ & $3.16 \mathrm{E}-06$ & $3.24 \mathrm{E}-06$ & $3.26 \mathrm{E}-06$ \\
\hline $\mathrm{Cm}-243$ & $2.79 \mathrm{E}-07$ & $1.84 \mathrm{E}-04$ & 0.132 & $2.73 \mathrm{E}-07$ & $2.75 \mathrm{E}-07$ & $2.82 \mathrm{E}-07$ & $2.84 \mathrm{E}-07$ \\
\hline $\mathrm{Cm}-244$ & $1.05 \mathrm{E}-05$ & $6.92 \mathrm{E}-03$ & 4.96 & $7.59 \mathrm{E}-06$ & $9.79 \mathrm{E}-06$ & $1.12 \mathrm{E}-05$ & $1.18 \mathrm{E}-05$ \\
\hline Tatals & $\mathbf{M}$ & 10/0 & $\mathrm{kg}$ & $\begin{array}{c}-95 \text { CI } \\
\text { M_ar } a / L \text { L }\end{array}$ & $\begin{array}{c}-67 \mathrm{CI} \\
\mathrm{M} / \mathrm{a} / \mathrm{a} / \mathrm{L}\end{array}$ & $\begin{array}{c}+67 \mathrm{CI} \\
\mathrm{M} / \mathrm{a} / \mathrm{L} / \mathrm{L}\end{array}$ & $\begin{array}{c}+95 \text { CI } \\
\text { (M_a/L_L }\end{array}$ \\
\hline $\mathrm{Pu}$ & $5.07 \mathrm{E}-02(\mathrm{~g} / \mathrm{L})$ & -- & 24.0 & $3.35 \mathrm{E}-02$ & $4.64 \mathrm{E}-02$ & $5.49 \mathrm{E}-02$ & $5.90 \mathrm{E}-02$ \\
\hline $\mathrm{U}$ & $6.24 \mathrm{E}-03$ & 982 & 703 & $6.04 \mathrm{E}-03$ & $6.14 \mathrm{E}-03$ & $6.36 \mathrm{E}-03$ & $6.41 \mathrm{E}-03$ \\
\hline
\end{tabular}

*Unknowns in tank solids inventory are assigned by Tank Layering Model (TLM).

$\dagger$ Volume average for density, mass average Water wt $\%$ and TOC wt $\%$ C.

A. 13 
HDW Model Rev. 4

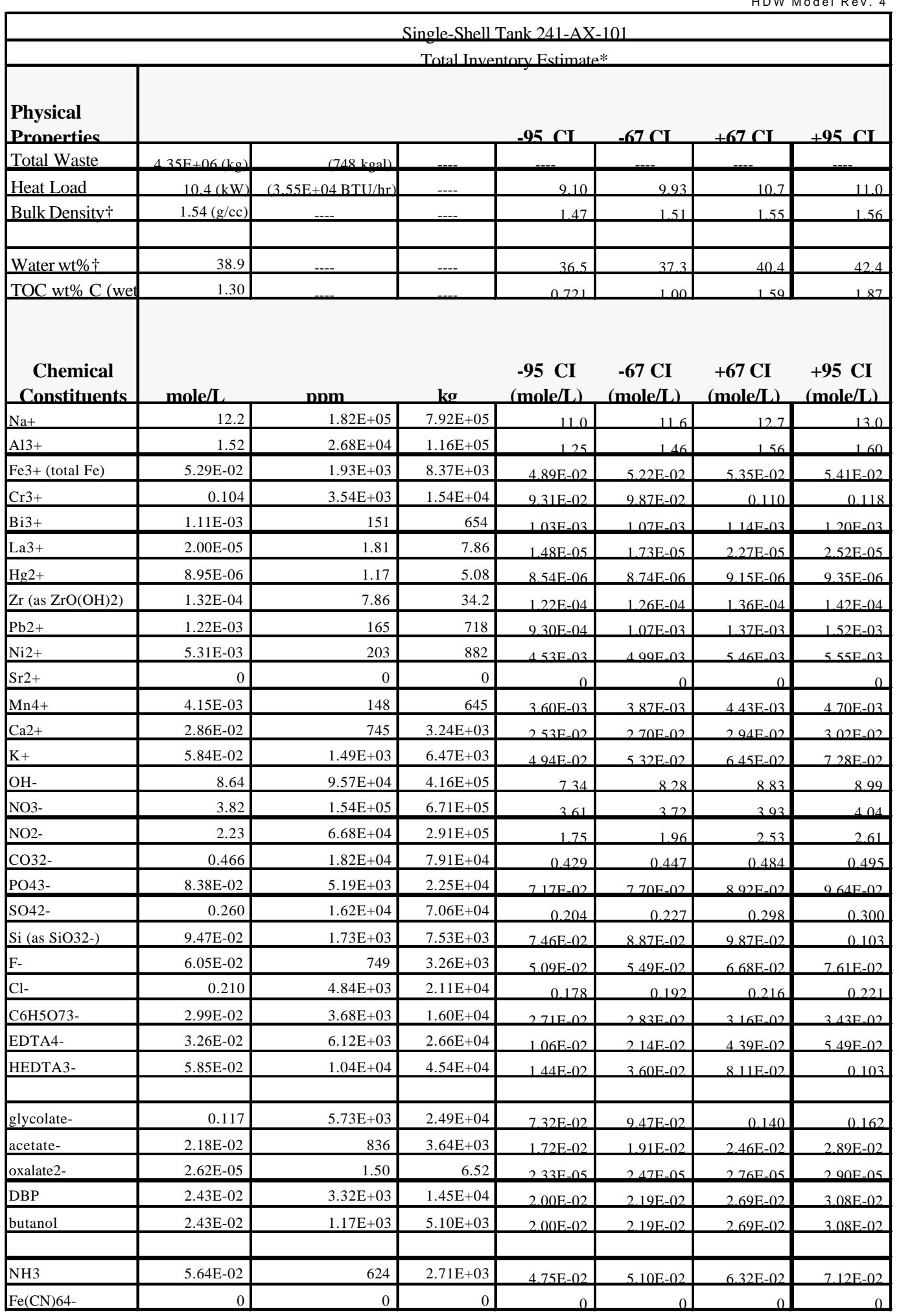

*Unknowns in tank solids inventory are assigned by Tank Layering Model (TLM).

$\dagger$ Water wt $\%$ derived from the difference of density and total dissolved species. 
HDW Model Rev. 4

\begin{tabular}{|c|c|c|c|c|c|c|c|}
\hline \multicolumn{8}{|c|}{ Single-Shell Tank 241-AX-101 } \\
\hline \multicolumn{8}{|c|}{ Total Inventory Estimate* } \\
\hline $\begin{array}{l}\text { Physical } \\
\text { Pronerties }\end{array}$ & & & & -95 CI & $-67 C L$ & $\pm 67 C I$ & +95 CI \\
\hline Total Waste & $4.35 \mathrm{E}+06(\mathrm{~kg})$ & (748 kgal) & -- & $\ldots$ & - & $-\ldots$ & $\ldots$ \\
\hline Heat Load & $10.4(\mathrm{~kW}$ & $(3.55 \mathrm{E}+04 \mathrm{BTU} / \mathrm{hr})$ & $\ldots$ & 9.10 & 9.93 & 10.7 & 11.0 \\
\hline Bulk Density & $1.54(\mathrm{~g} / \mathrm{ccc})$ & $\ldots$ & $\ldots$ & 1.47 & 1.51 & 1.55 & 1.56 \\
\hline Water wt $\% \div$ & 38.9 & $\ldots$ & $\ldots$ & 36.5 & 37.3 & 40.4 & 42.4 \\
\hline TOC wt $\% \mathrm{C}$ (wet & 1.30 & - & $\ldots$ & 0.721 & 1.00 & 1.59 & 1.87 \\
\hline Radiological & Cill & (A) & $\mathbf{C i}_{\mathbf{i}}$ & $05 \mathrm{CI}(\mathrm{Ci} / \mathrm{I})$ & $67 \mathrm{Cl}(\mathrm{Ci} / \mathrm{I})$ & $167 \mathrm{CI}(\mathrm{Ci} / \mathrm{I})$ & CI $(\mathrm{Ci} / \mathrm{I})$ \\
\hline $\mathrm{H}-3$ & $2.21 \mathrm{E}-04$ & 0.144 & 625 & $1.51 \mathrm{E}-04$ & $1.51 \mathrm{E}-04$ & $2.38 \mathrm{E}-04$ & $2.59 \mathrm{E}-04$ \\
\hline C-14 & $3.49 \mathrm{E}-05$ & $2.27 \mathrm{E}-02$ & 98.7 & $2.02 \mathrm{E}-05$ & $2.02 \mathrm{E}-05$ & $3.55 \mathrm{E}-05$ & $3.62 \mathrm{E}-05$ \\
\hline $\mathrm{Ni}-59$ & $5.77 \mathrm{E}-06$ & $3.75 \mathrm{E}-03$ & 16.3 & $4.19 \mathrm{E}-06$ & $5.08 \mathrm{E}-06$ & $6.08 \mathrm{E}-06$ & $6.26 \mathrm{E}-06$ \\
\hline Ni-63 & $5.71 \mathrm{E}-04$ & 0.372 & $1.62 \mathrm{E}+03$ & $4.13 \mathrm{E}-04$ & 5.03E-04 & $6.03 \mathrm{E}-04$ & $6.21 \mathrm{E}-04$ \\
\hline $\mathrm{Co}-60$ & 4.46E- 05 & $2.91 \mathrm{E}-02$ & 126 & $2.79 \mathrm{E}-05$ & $2.79 \mathrm{E}-05$ & $4.58 \mathrm{E}-05$ & $4.80 \mathrm{E}-05$ \\
\hline Se-79 & $6.24 \mathrm{E}-06$ & 4.07E- 03 & 17.7 & $4.89 \mathrm{E}-06$ & 5.31E-06 & $6.78 \mathrm{E}-06$ & $7.30 \mathrm{E}-06$ \\
\hline Sr-90 & 0.360 & 234 & $1.02 \mathrm{E}+06$ & 0.313 & 0.346 & 0.365 & 0.369 \\
\hline$Y-90$ & 0.360 & 234 & $1.02 \mathrm{E}+06$ & 0.313 & 0.327 & 0.366 & 0.369 \\
\hline Zr-93 & $2.95 \mathrm{E}-05$ & $1.92 \mathrm{E}-02$ & 83.4 & $2.27 \mathrm{E}-05$ & $2.48 \mathrm{E}-05$ & $3.22 \mathrm{E}-05$ & $3.48 \mathrm{E}-05$ \\
\hline $\mathrm{Nb}-93 \mathrm{~m}$ & $2.22 \mathrm{E}-05$ & $1.44 \mathrm{E}-02$ & 62.8 & $1.74 \mathrm{E}-05$ & $1.89 \mathrm{E}-05$ & $2.41 \mathrm{E}-05$ & $2.59 \mathrm{E}-05$ \\
\hline Tc-99 & $2.66 \mathrm{E}-04$ & 0.173 & 753 & $2.07 \mathrm{E}-04$ & $2.33 \mathrm{E}-04$ & $3.02 \mathrm{E}-04$ & $3.51 \mathrm{E}-04$ \\
\hline$R_{u-106}$ & $2.34 \mathrm{E}-08$ & $1.52 \mathrm{E}-05$ & $6.62 \mathrm{E}-02$ & $2.00 \mathrm{E}-08$ & $2.12 \mathrm{E}-08$ & $2.41 \mathrm{E}-08$ & $2.48 \mathrm{E}-08$ \\
\hline $\mathrm{Cd}-113 \mathrm{~m}$ & $1.34 \mathrm{E}-04$ & $8.76 \mathrm{E}-02$ & 381 & $1.05 \mathrm{E}-04$ & $1.06 \mathrm{E}-04$ & $1.48 \mathrm{E}-04$ & $1.63 \mathrm{E}-04$ \\
\hline Sh-125 & $2.01 \mathrm{E}-04$ & 0.131 & 568 & $1.26 \mathrm{E}-04$ & $1.26 \mathrm{E}-04$ & $2.08 \mathrm{E}-04$ & $2.15 \mathrm{E}-04$ \\
\hline Sn-126 & $9.63 \mathrm{E}-06$ & $6.27 \mathrm{E}-03$ & 27.3 & $7.60 \mathrm{E}-06$ & $8.23 \mathrm{E}-06$ & $1.04 \mathrm{E}-05$ & $1.12 \mathrm{E}-05$ \\
\hline I-129 & $5.14 \mathrm{E}-07$ & 3.35E-04 & 1.45 & $4.00 \mathrm{E}-07$ & $4.51 \mathrm{E}-07$ & $5.84 \mathrm{E}-07$ & $6.80 \mathrm{E}-07$ \\
\hline Cs-134 & $3.99 \mathrm{E}-06$ & $2.60 \mathrm{E}-03$ & 11.3 & $2.33 \mathrm{E}-06$ & $3.14 \mathrm{E}-06$ & $4.85 \mathrm{E}-06$ & $5.68 \mathrm{E}-06$ \\
\hline Cs- 137 & 0.266 & 173 & $7.54 \mathrm{E}+05$ & 0.234 & 0.248 & 0.283 & 0.308 \\
\hline Ba- $137 \mathrm{~m}$ & 0.252 & 164 & $7.13 \mathrm{E}+05$ & 0.205 & 0.205 & 0.267 & 0.281 \\
\hline $\mathrm{Sm}-151$ & $2.26 \mathrm{E}-02$ & 14.7 & $6.39 \mathrm{E}+04$ & $1.78 \mathrm{E}-02$ & $1.93 \mathrm{E}-02$ & $2.45 \mathrm{E}-02$ & $2.63 \mathrm{E}-02$ \\
\hline Eu-152 & $7.56 \mathrm{E}-06$ & 4.93E- 03 & 21.4 & $6.38 \mathrm{E}-06$ & $6.41 \mathrm{E}-06$ & $8.17 \mathrm{E}-06$ & $8.77 \mathrm{E}-06$ \\
\hline Eul-154 & $8.14 \mathrm{E}-04$ & 0.530 & $2.30 \mathrm{E}+03$ & $5.80 \mathrm{E}-04$ & $5.80 \mathrm{E}-04$ & $8.98 \mathrm{E}-04$ & $9.57 \mathrm{E}-04$ \\
\hline Eul-155 & $4.80 \mathrm{E}-04$ & 0.313 & $1.36 \mathrm{E}+03$ & $4.08 \mathrm{E}-04$ & 4.12E-04 & $5.18 \mathrm{E}-04$ & $5.54 \mathrm{E}-04$ \\
\hline Ra-226 & $3.91 \mathrm{E}-10$ & $2.55 \mathrm{E}-07$ & $1.11 \mathrm{E}-03$ & $3.49 \mathrm{E}-10$ & $3.62 \mathrm{E}-10$ & $4.08 \mathrm{E}-10$ & $4.24 \mathrm{E}-10$ \\
\hline Ra-228 & $3.59 \mathrm{E}-07$ & 2.34E-04 & 1.02 & $9.39 \mathrm{E}-08$ & $9.39 \mathrm{E}-08$ & $3.92 \mathrm{E}-07$ & $4.28 \mathrm{E}-07$ \\
\hline Ac-227 & $2.18 \mathrm{E}-09$ & 1.42E-06 & $6.17 \mathrm{E}-03$ & $1.94 \mathrm{E}-09$ & $2.01 \mathrm{E}-09$ & $2.28 \mathrm{E}-09$ & $2.37 \mathrm{E}-09$ \\
\hline Pa-231 & $6.34 \mathrm{E}-09$ & 4.13E-06 & $1.80 \mathrm{E}-02$ & $5.16 \mathrm{E}-09$ & $5.41 \mathrm{E}-09$ & $6.88 \mathrm{E}-09$ & $7.40 \mathrm{E}-09$ \\
\hline Th-229 & $8.32 \mathrm{E}-09$ & $5.42 \mathrm{E}-06$ & $2.35 \mathrm{E}-02$ & $2.20 \mathrm{E}-09$ & $2.20 \mathrm{E}-09$ & $9.05 \mathrm{E}-09$ & $9.83 \mathrm{E}-09$ \\
\hline Th-232 & $3.88 \mathrm{E}-08$ & $2.53 \mathrm{E}-05$ & 0.110 & $6.06 \mathrm{E}-09$ & $6.06 \mathrm{E}-09$ & 4.77E- 08 & $5.63 \mathrm{E}-08$ \\
\hline U-232 & $1.06 \mathrm{E}-06$ & $6.90 \mathrm{E}-04$ & 3.00 & $8.12 \mathrm{E}-07$ & $9.11 \mathrm{E}-07$ & $1.23 \mathrm{E}-06$ & $1.41 \mathrm{E}-06$ \\
\hline U-233 & $4.06 \mathrm{E}-06$ & $2.65 \mathrm{E}-03$ & 11.5 & $3.11 \mathrm{E}-06$ & 3.49E-06 & $4.71 \mathrm{E}-06$ & $5.41 \mathrm{E}-06$ \\
\hline U-234 & $6.50 \mathrm{E}-07$ & 4.24E-04 & 1.84 & $6.30 \mathrm{E}-07$ & $6.42 \mathrm{E}-07$ & $6.59 \mathrm{E}-07$ & $6.66 \mathrm{E}-07$ \\
\hline U-235 & $2.57 \mathrm{E}-08$ & $1.68 \mathrm{E}-05$ & $7.29 \mathrm{E}-02$ & $2.49 \mathrm{E}-08$ & $2.54 \mathrm{E}-08$ & $2.61 \mathrm{E}-08$ & $2.64 \mathrm{E}-08$ \\
\hline U-236 & $2.10 \mathrm{E}-08$ & $1.37 \mathrm{E}-05$ & $5.94 \mathrm{E}-02$ & $2.04 \mathrm{E}-08$ & $2.07 \mathrm{E}-08$ & $2.12 \mathrm{E}-08$ & $2.15 \mathrm{E}-08$ \\
\hline U-238 & $9.10 \mathrm{E}-07$ & $5.93 \mathrm{E}-04$ & 2.58 & $8.91 \mathrm{E}-07$ & $9.02 \mathrm{E}-07$ & $9.18 \mathrm{E}-07$ & $9.51 \mathrm{E}-07$ \\
\hline $\mathrm{Nn}-237$ & $9.20 \mathrm{E}-07$ & $5.99 \mathrm{E}-04$ & 2.60 & $7.29 \mathrm{E}-07$ & $8.14 \mathrm{E}-07$ & $1.04 \mathrm{E}-06$ & $1.20 \mathrm{E}-06$ \\
\hline Рu-238 & 4.56E- 06 & $2.97 \mathrm{E}-03$ & 12.9 & $3.90 \mathrm{E}-06$ & 4.43E-06 & $4.66 \mathrm{E}-06$ & 4.77E-06 \\
\hline $\mathrm{P}_{\mathrm{II}-239}$ & $1.30 \mathrm{E}-04$ & $8.46 \mathrm{E}-02$ & 368 & $1.12 \mathrm{E}-04$ & $1.27 \mathrm{E}-04$ & $1.33 \mathrm{E}-04$ & $1.35 \mathrm{E}-04$ \\
\hline $\mathrm{Pu}-240$ & $2.37 \mathrm{E}-05$ & $1.54 \mathrm{E}-02$ & 67.1 & $2.05 \mathrm{E}-05$ & $2.31 \mathrm{E}-05$ & $2.42 \mathrm{E}-05$ & $2.47 \mathrm{E}-05$ \\
\hline $\mathrm{Pu}-241$ & $3.21 \mathrm{E}-04$ & 0.209 & 910 & $2.75 \mathrm{E}-04$ & $3.12 \mathrm{E}-04$ & $3.29 \mathrm{E}-04$ & $3.36 \mathrm{E}-04$ \\
\hline $\mathrm{Pu}-242$ & $1.84 \mathrm{E}-09$ & $1.20 \mathrm{E}-06$ & $5.22 \mathrm{E}-03$ & $1.57 \mathrm{E}-09$ & $1.79 \mathrm{E}-09$ & $1.89 \mathrm{E}-09$ & $1.93 \mathrm{E}-09$ \\
\hline$\Delta \mathrm{m}-241$ & $1.65 \mathrm{E}-04$ & 0.107 & 466 & $1.44 \mathrm{E}-04$ & $1.57 \mathrm{E}-04$ & $1.73 \mathrm{E}-04$ & $1.81 \mathrm{E}-04$ \\
\hline Am-243 & $6.74 \mathrm{E}-09$ & $4.39 \mathrm{E}-06$ & $1.91 \mathrm{E}-02$ & $5.95 \mathrm{E}-09$ & $6.52 \mathrm{E}-09$ & $6.99 \mathrm{E}-09$ & $7.20 \mathrm{E}-09$ \\
\hline $\mathrm{Cm}-242$ & $2.48 \mathrm{E}-07$ & 1.62E-04 & 0.703 & $2.01 \mathrm{E}-07$ & $2.01 \mathrm{E}-07$ & $2.71 \mathrm{E}-07$ & $2.94 \mathrm{E}-07$ \\
\hline $\mathrm{Cm}-243$ & $2.22 \mathrm{E}-08$ & $1.45 \mathrm{E}-05$ & $6.28 \mathrm{E}-02$ & $1.77 \mathrm{E}-08$ & $1.77 \mathrm{E}-08$ & $2.43 \mathrm{E}-08$ & $2.63 \mathrm{E}-08$ \\
\hline $\mathrm{Cm}-244$ & $4.04 \mathrm{E}-07$ & $2.63 \mathrm{E}-04$ & 1.15 & $3.37 \mathrm{E}-07$ & $3.58 \mathrm{E}-07$ & 4.20E- -07 & $4.30 \mathrm{E}-07$ \\
\hline Tatals & $\mathbf{M}$ & Ho/a & ko & 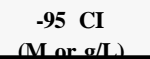 & $\begin{array}{c}-67 \mathrm{CI} \\
\mathrm{Mor} \sigma / \mathrm{L})\end{array}$ & $\begin{array}{c}+67 \mathrm{CI} \\
(\mathrm{M} / \mathrm{ar} / \mathrm{L}\end{array}$ & $\begin{array}{c}+95 \text { CI } \\
\text { (M) }\end{array}$ \\
\hline $\mathrm{Pu}$ & $1.93 \mathrm{E}-03(\mathrm{~g} / \mathrm{L})$ & --- & 5.47 & $1.64 \mathrm{E}-03$ & $1.88 \mathrm{E}-03$ & $1.99 \mathrm{E}-03$ & $2.03 \mathrm{E}-03$ \\
\hline $\mathrm{U}$ & $7.28 \mathrm{E}-03$ & $1.13 \mathrm{E}+03$ & $4.91 \mathrm{E}+03$ & $7.04 \mathrm{E}-03$ & $7.18 \mathrm{E}-03$ & $7.39 \mathrm{E}-03$ & 7.47E- 03 \\
\hline
\end{tabular}

*Unknowns in tank solids inventory are assigned by Tank Layering Model (TLM).

$\dagger$ Volume average for density, mass average Water wt $\%$ and TOC wt $\%$ C. 
HDW Model Rev. 4

\begin{tabular}{|c|c|c|c|c|c|c|c|}
\hline & & & ingle-Shell & ank 241-AX & & & \\
\hline & & & Total Inve & tory Estimat & & & \\
\hline \begin{tabular}{|l} 
Physical \\
Properties \\
\end{tabular} & & & & $-95 \mathrm{CI}$ & $-67 C I$ & $+67 \mathrm{CI}$ & $+95 \mathrm{CI}$ \\
\hline Total Waste & $229 \mathrm{E}+05(\mathrm{~kg})$ & $(390 \mathrm{kgal})$ & & &  & & \\
\hline Heat Load & $133(\mathrm{~kW})$ & $(4.54 \mathrm{E}+03 \mathrm{BTU} / \mathrm{hr}$ & & 0272 & 0659 & 159 & 173 \\
\hline Bulk Density $\dagger$ & $1.55(\mathrm{~g} / \mathrm{cc})$ & & & 1.51 & 1.53 & 1.58 & 1.59 \\
\hline & & & & & & & \\
\hline Water wt $\% \dagger$ & 38.1 & & & 36.2 & 36.8 & 391 & 40.3 \\
\hline TOC wt $\% \mathrm{C}$ (wet & 0.983 & & & 0583 & 0770 & 110 & 138 \\
\hline $\begin{array}{c}\text { Chemical } \\
\text { Constituents }\end{array}$ & mole/L & nnm & $\mathrm{kg}$ & $\begin{array}{c}-95 \text { CI } \\
\text { (mole/L) }\end{array}$ & $\begin{array}{c}-67 \mathrm{CI} \\
(\mathrm{mole} / \mathrm{L})\end{array}$ & $\begin{array}{c}+67 \mathrm{CI} \\
(\mathrm{mole} / \mathrm{L})\end{array}$ & $\begin{array}{r}+95 \mathrm{CI} \\
(\mathrm{mole} / \mathrm{L})\end{array}$ \\
\hline $\mathrm{Na}+$ & 12.2 & $1.81 \mathrm{E}+05$ & $4.15 \mathrm{E}+04$ & 115 & 118 & 128 & 13.1 \\
\hline $\mathrm{Al} 3+$ & 1.61 & $2.79 \mathrm{E}+04$ & $6.39 \mathrm{E}+03$ & 144 & 1.57 & 165 & 168 \\
\hline $\mathrm{Fe} 3+$ (total $\mathrm{Fe}$ ) & 0.211 & $7.59 \mathrm{E}+03$ & $1.74 \mathrm{E}+03$ & $8.30 \mathrm{E}-02$ & 0.171 & 0.227 & 0235 \\
\hline $\mathrm{Cr} 3+$ & 0.111 & $3.72 \mathrm{E}+03$ & 852 & $2.57 \mathrm{E}-02$ & 0.104 & 0.114 & 0.119 \\
\hline $\mathrm{Bi} 3+$ & $1.06 \mathrm{E}-03$ & 142 & 32.6 & $288 \mathrm{E}-04$ & $102 \mathrm{E}-03$ & $109 \mathrm{E}-03$ & $1.13 \mathrm{E}-03$ \\
\hline $\mathrm{La} 3+$ & $2.20 \mathrm{E}-05$ & 1.97 & 0.452 & $161 \mathrm{E}-05$ & $190 \mathrm{E}-05$ & $2.51 \mathrm{E}-05$ & $280 \mathrm{E}-05$ \\
\hline $\mathrm{Hg} 2+$ & $8.09 \mathrm{E}-06$ & 1.05 & 0.239 & $772 \mathrm{E}-\mathrm{O} 6$ & $703 \mathrm{E}-\mathrm{O} 6$ & $821 \mathrm{E}-06$ & $833 \mathrm{E}-06$ \\
\hline $\mathrm{Zr}$ (as $\mathrm{ZrO}(\mathrm{OH}) 2)$ & $1.55 \mathrm{E}-04$ & 9.08 & 2.08 & $120 \mathrm{E}-\mathrm{A}$ & $146 \mathrm{E}-\mathrm{OA}$ & $160 \mathrm{E}-04$ & $167 \mathrm{E}-04$ \\
\hline $\mathrm{Pb} 2+$ & $1.04 \mathrm{E}-03$ & 138 & 31.7 & $856 \mathrm{E}-04$ & Q Q AME-OA & 1 13E_-03 & $122 \mathrm{E}-03$ \\
\hline $\mathrm{Ni2+}$ & $1.28 \mathrm{E}-02$ & 483 & 111 & $735 \mathrm{E}-03$ & $751 \mathrm{E}-03$ & $268 \mathrm{E}-02$ & $340 \mathrm{E}-02$ \\
\hline $\mathrm{Sr} 2+$ & 0 & 0 & 0 & & & & \\
\hline Mn4+ & $3.68 \mathrm{E}-03$ & 130 & 29.8 & $3.07 \mathrm{E}-03$ & $3.37 \mathrm{E}-03$ & $399 \mathrm{E}-03$ & $4.29 \mathrm{E}-03$ \\
\hline $\mathrm{Ca} 2+$ & $6.52 \mathrm{E}-02$ & $1.68 \mathrm{E}+03$ & 386 & $3.65 \mathrm{E}-02$ & $3.73 \mathrm{E}-02$ & 0.135 & 0.171 \\
\hline $\mathrm{K}+$ & $5.59 \mathrm{E}-02$ & $1.41 \mathrm{E}+03$ & 323 & $504 \mathrm{E}-02$ & $527 \mathrm{E}-02$ & 5 .97E- 02 & $6.47 \mathrm{E}-02$ \\
\hline $\mathrm{OH}-$ & 9.45 & $1.04 \mathrm{E}+05$ & $2.37 \mathrm{E}+04$ & 8.65 & 920 & 971 & 2.84 \\
\hline NO3- & 4.00 & $1.60 \mathrm{E}+05$ & $3.66 \mathrm{E}+04$ & 3.78 & 3.90 & 4.32 & 4.13 \\
\hline NO2- & 2.14 & $6.35 \mathrm{E}+04$ & $1.45 \mathrm{E}+04$ & 1.85 & 1.97 & 2.32 & 2.41 \\
\hline $\mathrm{CO} 32-$ & 0.447 & $1.73 \mathrm{E}+04$ & $3.96 \mathrm{E}+03$ & م.414 & 0410 & مـ517 & 0553 \\
\hline PO43- & $7.84 \mathrm{E}-02$ & $4.80 \mathrm{E}+03$ & $1.10 \mathrm{E}+03$ & $709 \mathrm{E}-02$ & $735 \mathrm{E}-02$ & $8 \quad 17 \mathrm{E}-02$ & $861 \mathrm{E}-02$ \\
\hline SO42- & 0.232 & $1.44 \mathrm{E}+04$ & $3.29 \mathrm{E}+03$ & ــــ & 0212 & 0255 & 0266 \\
\hline $\mathrm{Si}$ (as $\mathrm{SiO} 32-$ ) & 0.223 & $4.04 \mathrm{E}+03$ & 925 & $647 \mathrm{E}-02$ & $677 \mathrm{E}-02$ & 0.488 & 6.650 \\
\hline F- & $5.56 \mathrm{E}-02$ & 681 & 156 & $4.96 \mathrm{E}-02$ & $521 \mathrm{E}-02$ & $594 \mathrm{E}-02$ & $651 \mathrm{E}-02$ \\
\hline $\mathrm{Cl}-$ & 0.205 & $4.68 \mathrm{E}+03$ & $1.07 \mathrm{E}+03$ & 0.185 & 0.194 & 0.212 & 0.218 \\
\hline C6H5O73- & $2.78 \mathrm{E}-02$ & $3.38 \mathrm{E}+03$ & 775 & $2.59 \mathrm{E}-02$ & $2.68 \mathrm{E}-02$ & $2.88 \mathrm{E}-02$ & $3.05 \mathrm{E}-02$ \\
\hline EDTA4- & $2.28 \mathrm{E}-02$ & $4.24 \mathrm{E}+03$ & 971 & $7.45 \mathrm{E}-03$ & $1.50 \mathrm{E}-02$ & $3.08 \mathrm{E}-02$ & $3.85 \mathrm{E}-02$ \\
\hline HEDTA3- & $4.10 \mathrm{E}-02$ & $7.24 \mathrm{E}+03$ & $1.66 \mathrm{E}+03$ & $1.02 \mathrm{E}-02$ & $2.52 \mathrm{E}-02$ & $568 \mathrm{E}-02$ & $723 \mathrm{E}-02$ \\
\hline glycolate- & $9.43 \mathrm{E}-02$ & $4.56 \mathrm{E}+03$ & $1.04 \mathrm{E}+03$ & $6.35 \mathrm{E}-02$ & $786 \mathrm{E}-02$ & 0.110 & 0.126 \\
\hline acetate- & $1.50 \mathrm{E}-02$ & 571 & 131 & $122 \mathrm{E}-02$ & $134 \mathrm{E}-02$ & 1 67E-02 & $194 \mathrm{E}-02$ \\
\hline oxalate2- & $2.89 \mathrm{E}-05$ & 1.64 & 0.375 & $257 \mathrm{E}-05$ & $272 \mathrm{E}-05$ & $305 \mathrm{E}-05$ & $321 \mathrm{E}-05$ \\
\hline DBP & $2.06 \mathrm{E}-02$ & $2.80 \mathrm{E}+03$ & 640 & $180 \mathrm{E}-02$ & $192 \mathrm{E}-02$ & $222 \mathrm{E}-02$ & $246 \mathrm{E}-02$ \\
\hline butanol & $2.06 \mathrm{E}-02$ & 986 & 226 & $180 \mathrm{E}-\mathrm{CO}$ & $102 \mathrm{E}-\mathrm{O} 2$ & $222 \mathrm{E}-02$ & $246 \mathrm{E}-02$ \\
\hline & & & & & & & \\
\hline $\mathrm{NH} 3$ & $6.50 \mathrm{E}-02$ & 712 & 163 & $5.51 \mathrm{E}-02$ & $5.90 \mathrm{E}-02$ & $726 \mathrm{E}-02$ & $8.15 \mathrm{E}-02$ \\
\hline $\mathrm{Fe}(\mathrm{CN}) 64-$ & 0 & 0 & 0 & 0 & 0 & 0 & 0 \\
\hline
\end{tabular}

*Unknowns in tank solids inventory are assigned by Tank Layering Model (TLM).

$\dagger$ Water wt $\%$ derived from the difference of density and total dissolved species. 
HDW Model Rev. 4

\begin{tabular}{|c|c|c|c|c|c|c|c|}
\hline \multicolumn{8}{|c|}{ Single-Shell Tank 241-AX-102 } \\
\hline \multicolumn{8}{|c|}{ Total Inventory Estimate* } \\
\hline $\begin{array}{l}\text { Physical } \\
\text { Pronerties }\end{array}$ & & & & $.05 \mathrm{CI}$ & $.67 \mathrm{CI}$ & $+67 \mathrm{CI}$ & $+95 \mathrm{CI}$ \\
\hline Total Waste & $2.29 \mathrm{E}+05(\mathrm{~kg})$ & $(39.0 \mathrm{kgal})$ & -..- & -.-- & $\ldots$ & $\ldots$ & $\ldots$ \\
\hline Heat Load & $1.33(\mathrm{~kW})$ & $(4.54 \mathrm{E}+03 \mathrm{BTU} / \mathrm{hr}$ & $-\ldots$ & 0.272 & 0.659 & 1.59 & 1.73 \\
\hline Bulk Density & $1.55(\mathrm{~g} / \mathrm{cc})$ & $\ldots$ & $\ldots$ & 1.51 & 1.53 & 1.58 & 1.59 \\
\hline Water wt $\% \div$ & 38.1 & --- & $\ldots$ & 36.2 & 36.8 & 39.1 & 40.3 \\
\hline TOC wt $\% \mathrm{C}$ (wet & 0.983 & --- & $-\ldots$ & 0.583 & 0.779 & 1.19 & 1.38 \\
\hline $\begin{array}{l}\text { Radiological } \\
\text { Constituents }\end{array}$ & Ii/L. & ل & تــ & $-95 \mathrm{CL}(\mathrm{Ci} / \mathrm{L})$ & -67CI (Ci/L) & $\pm 67 \mathrm{CL}(\mathrm{Ci} / \mathrm{L})$ & $+95 \mathrm{CL}(\mathrm{Ci} / \mathrm{L})$ \\
\hline $\mathrm{H}-3$ & $2.19 \mathrm{E}-04$ & 0.141 & 32.4 & $1.41 \mathrm{E}-04$ & $1.41 \mathrm{E}-04$ & $2.31 \mathrm{E}-04$ & $2.46 \mathrm{E}-04$ \\
\hline $\mathrm{C}-14$ & $3.45 \mathrm{E}-05$ & $2.23 \mathrm{E}-02$ & 5.10 & $1.82 \mathrm{E}-05$ & $1.82 \mathrm{E}-05$ & $3.52 \mathrm{E}-05$ & $3.59 \mathrm{E}-05$ \\
\hline $\mathrm{Ni}-59$ & $1.06 \mathrm{E}-05$ & $6.84 \mathrm{E}-03$ & 1.57 & $1.83 \mathrm{E}-06$ & $2.07 \mathrm{E}-06$ & $3.34 \mathrm{E}-05$ & $4.51 \mathrm{E}-05$ \\
\hline $\mathrm{Ni}-63$ & $1.09 \mathrm{E}-03$ & 0.704 & 161 & $1.79 \mathrm{E}-04$ & $2.05 \mathrm{E}-04$ & $3.46 \mathrm{E}-03$ & $4.67 \mathrm{E}-03$ \\
\hline $\mathrm{Co}_{0}-60$ & $4.48 \mathrm{E}-05$ & $2.89 \mathrm{E}-02$ & 6.61 & $2.61 \mathrm{E}-05$ & $2.61 \mathrm{E}-05$ & 4.65E-05 & $3.16 \mathrm{E}-04$ \\
\hline Se-79 & $3.58 \mathrm{E}-05$ & $2.31 \mathrm{E}-02$ & 5.29 & $3.20 \mathrm{E}-06$ & $3.45 \mathrm{E}-06$ & $5.42 \mathrm{E}-05$ & $7.18 \mathrm{E}-05$ \\
\hline Sr-90 & 1.16 & 749 & $1.72 \mathrm{E}+05$ & 0.101 & 0.488 & 1.43 & 1.56 \\
\hline $\mathrm{Y}-90$ & 1.16 & 750 & $1.72 \mathrm{E}+05$ & 0.101 & 0.488 & 1.43 & 1.56 \\
\hline Zr-93 & $1.58 \mathrm{E}-04$ & 0.102 & 23.3 & $1.58 \mathrm{E}-05$ & $1.69 \mathrm{E}-05$ & $2.50 \mathrm{E}-04$ & $3.38 \mathrm{E}-04$ \\
\hline $\mathrm{Nh}-93 \mathrm{~m}$ & $1.06 \mathrm{E}-04$ & $6.83 \mathrm{E}-02$ & 15.6 & $1.13 \mathrm{E}-05$ & $1.22 \mathrm{E}-05$ & $1.70 \mathrm{E}-04$ & $2.32 \mathrm{E}-04$ \\
\hline$T_{c-99}$ & $2.55 \mathrm{E}-04$ & 0.165 & 37.7 & $1.94 \mathrm{E}-04$ & $2.24 \mathrm{E}-04$ & $2.87 \mathrm{E}-04$ & $3.17 \mathrm{E}-04$ \\
\hline Ru-106 & $3.96 \mathrm{E}-06$ & $2.55 \mathrm{E}-03$ & 0.585 & $3.20 \mathrm{E}-06$ & 3.86E-06 & $4.01 \mathrm{E}-06$ & $4.05 \mathrm{E}-06$ \\
\hline $\mathrm{Cd}-113 \mathrm{~m}$ & 7.95E-04 & 0.513 & 117 & $8.54 \mathrm{E}-05$ & $9.21 \mathrm{E}-05$ & $1.35 \mathrm{E}-03$ & $1.87 \mathrm{E}-03$ \\
\hline Sb- 125 & $2.09 \mathrm{E}-04$ & 0.134 & 30.8 & $1.28 \mathrm{E}-04$ & $1.28 \mathrm{E}-04$ & $2.19 \mathrm{E}-04$ & $2.29 \mathrm{E}-04$ \\
\hline Sn-126 & 5.65E-05 & $3.64 \mathrm{E}-02$ & 8.35 & 4.84E-06 & $5.22 \mathrm{E}-06$ & $8.41 \mathrm{E}-05$ & $1.11 \mathrm{E}-04$ \\
\hline $\mathrm{L}-129$ & $4.93 \mathrm{E}-07$ & $3.18 \mathrm{E}-04$ & $7.28 \mathrm{E}-02$ & $3.75 \mathrm{E}-07$ & 4.33E-07 & $5.54 \mathrm{E}-07$ & $6.13 \mathrm{E}-07$ \\
\hline Cs- 134 & $3.41 \mathrm{E}-06$ & $2.20 \mathrm{E}-03$ & 0.504 & $2.25 \mathrm{E}-06$ & $2.82 \mathrm{E}-06$ & $4.01 \mathrm{E}-06$ & 4.60E-06 \\
\hline Cs-137 & 0.252 & 163 & $3.73 \mathrm{E}+04$ & 0.230 & 0.241 & 0.264 & 0.278 \\
\hline $\mathrm{Ba}-137 \mathrm{~m}$ & 0.239 & 154 & $3.52 \mathrm{E}+04$ & 0.203 & 0.203 & 0.250 & 0.260 \\
\hline Sm-151 & 0.105 & 67.9 & $1.55 \mathrm{E}+04$ & $1.12 \mathrm{E}-02$ & $1.21 \mathrm{E}-02$ & 0.170 & 0.231 \\
\hline Eu-152 & 1.43E-04 & $9.19 \mathrm{E}-02$ & 21.1 & $1.41 \mathrm{E}-04$ & $1.41 \mathrm{E}-04$ & $1.43 \mathrm{E}-04$ & $1.43 \mathrm{E}-04$ \\
\hline Eu-154 & $1.12 \mathrm{E}-02$ & 7.23 & $1.66 \mathrm{E}+03$ & $6.24 \mathrm{E}-04$ & $1.29 \mathrm{E}-03$ & $1.58 \mathrm{E}-02$ & $2.02 \mathrm{E}-02$ \\
\hline Eu-155 & $6.95 \mathrm{E}-03$ & 4.48 & $1.03 \mathrm{E}+03$ & $6.87 \mathrm{E}-03$ & $6.87 \mathrm{E}-03$ & $6.98 \mathrm{E}-03$ & $7.00 \mathrm{E}-03$ \\
\hline Ra-226 & $1.58 \mathrm{E}-09$ & $1.02 \mathrm{E}-06$ & $2.34 \mathrm{E}-04$ & $1.27 \mathrm{E}-10$ & 3.53E-10 & $2.15 \mathrm{E}-09$ & $2.70 \mathrm{E}-09$ \\
\hline $\mathrm{Ra}-228$ & $2.57 \mathrm{E}-07$ & $1.66 \mathrm{E}-04$ & $3.79 \mathrm{E}-02$ & $9.51 \mathrm{E}-08$ & $9.51 \mathrm{E}-08$ & $2.91 \mathrm{E}-07$ & $3.27 \mathrm{E}-07$ \\
\hline$A c-227$ & 7.70E-09 & $4.96 \mathrm{E}-06$ & $1.14 \mathrm{E}-03$ & $7.88 \mathrm{E}-10$ & $8.36 \mathrm{E}-10$ & $1.10 \mathrm{E}-08$ & $1.42 \mathrm{E}-08$ \\
\hline $\mathrm{Pa}-231$ & $4.00 \mathrm{E}-09$ & $2.58 \mathrm{E}-06$ & $5.91 \mathrm{E}-04$ & $2.96 \mathrm{E}-09$ & $2.96 \mathrm{E}-09$ & $2.24 \mathrm{E}-08$ & 4.00E-08 \\
\hline Th-229 & $5.98 \mathrm{E}-09$ & $3.85 \mathrm{E}-06$ & $8.82 \mathrm{E}-04$ & $2.24 \mathrm{E}-09$ & $2.24 \mathrm{E}-09$ & $6.72 \mathrm{E}-09$ & 7.51E-09 \\
\hline Th-232 & $2.62 \mathrm{E}-08$ & $1.69 \mathrm{E}-05$ & $3.86 \mathrm{E}-03$ & $6.15 \mathrm{E}-09$ & $6.15 \mathrm{E}-09$ & $3.16 \mathrm{E}-08$ & 3.69E- 08 \\
\hline U-232 & $8.51 \mathrm{E}-07$ & $5.48 \mathrm{E}-04$ & 0.126 & $6.22 \mathrm{E}-07$ & 7.34E-07 & $9.87 \mathrm{E}-07$ & $1.13 \mathrm{E}-06$ \\
\hline U-233 & $3.26 \mathrm{E}-06$ & $2.10 \mathrm{E}-03$ & 0.482 & $2.38 \mathrm{E}-06$ & $2.81 \mathrm{E}-06$ & $3.78 \mathrm{E}-06$ & $4.34 \mathrm{E}-06$ \\
\hline U-234 & $6.71 \mathrm{E}-07$ & $4.32 \mathrm{E}-04$ & $9.90 \mathrm{E}-02$ & $6.49 \mathrm{E}-07$ & $6.60 \mathrm{E}-07$ & $6.82 \mathrm{E}-07$ & $6.88 \mathrm{E}-07$ \\
\hline U-235 & $2.68 \mathrm{E}-08$ & $1.73 \mathrm{E}-05$ & $3.96 \mathrm{E}-03$ & $2.59 \mathrm{E}-08$ & $2.64 \mathrm{E}-08$ & $2.73 \mathrm{E}-08$ & $2.75 \mathrm{E}-08$ \\
\hline U-236 & $2.19 \mathrm{E}-08$ & $1.41 \mathrm{E}-05$ & $3.23 \mathrm{E}-03$ & $2.09 \mathrm{E}-08$ & $2.14 \mathrm{E}-08$ & $2.22 \mathrm{E}-08$ & $2.25 \mathrm{E}-08$ \\
\hline U-238 & $8.62 \mathrm{E}-07$ & $5.55 \mathrm{E}-04$ & 0.127 & $8.42 \mathrm{E}-07$ & $8.51 \mathrm{E}-07$ & $8.73 \mathrm{E}-07$ & $8.87 \mathrm{E}-07$ \\
\hline $\mathrm{Nn}-237$ & $8.99 \mathrm{E}-07$ & $5.79 \mathrm{E}-04$ & 0.133 & $7.00 \mathrm{E}-07$ & 7.97E-07 & $1.00 \mathrm{E}-06$ & $1.10 \mathrm{E}-06$ \\
\hline $\mathrm{Pu}-238$ & $4.11 \mathrm{E}-04$ & 0.265 & 60.7 & 2.23E-04 & $3.87 \mathrm{E}-04$ & $4.22 \mathrm{E}-04$ & $4.33 \mathrm{E}-04$ \\
\hline $\mathrm{Pu}-239$ & $2.81 \mathrm{E}-03$ & 1.81 & 415 & $1.54 \mathrm{E}-03$ & $2.65 \mathrm{E}-03$ & $2.89 \mathrm{E}-03$ & $2.96 \mathrm{E}-03$ \\
\hline $\mathrm{Pu}-240$ & $1.00 \mathrm{E}-03$ & 0.647 & 148 & 5.47E-04 & 9.44E-04 & $1.03 \mathrm{E}-03$ & $1.06 \mathrm{E}-03$ \\
\hline $\mathrm{Pu}-241$ & $2.84 \mathrm{E}-02$ & 18.3 & $4.20 \mathrm{E}+03$ & $1.54 \mathrm{E}-02$ & $2.67 \mathrm{E}-02$ & $2.92 \mathrm{E}-02$ & $3.00 \mathrm{E}-02$ \\
\hline $\mathrm{Pu}-242$ & $2.06 \mathrm{E}-07$ & $1.32 \mathrm{E}-04$ & $3.03 \mathrm{E}-02$ & $1.12 \mathrm{E}-07$ & $1.93 \mathrm{E}-07$ & $2.11 \mathrm{E}-07$ & $2.17 \mathrm{E}-07$ \\
\hline$A m-241$ & $9.02 \mathrm{E}-03$ & 5.81 & $1.33 \mathrm{E}+03$ & $4.44 \mathrm{E}-03$ & $8.42 \mathrm{E}-03$ & $9.30 \mathrm{E}-03$ & $9.56 \mathrm{E}-03$ \\
\hline$\Delta \mathrm{m}-243$ & $1.00 \mathrm{E}-06$ & $6.48 \mathrm{E}-04$ & 0.148 & 4.93E-07 & $9.38 \mathrm{E}-07$ & $1.04 \mathrm{E}-06$ & $1.07 \mathrm{E}-06$ \\
\hline $\mathrm{Cm}-242$ & $1.21 \mathrm{E}-05$ & $7.80 \mathrm{E}-03$ & 1.79 & $1.20 \mathrm{E}-05$ & $1.20 \mathrm{E}-05$ & $1.21 \mathrm{E}-05$ & $1.21 \mathrm{E}-05$ \\
\hline $\mathrm{Cm}-243$ & $1.48 \mathrm{E}-06$ & $9.52 \mathrm{E}-04$ & 0.218 & $1.47 \mathrm{E}-06$ & $1.47 \mathrm{E}-06$ & $1.48 \mathrm{E}-06$ & $1.48 \mathrm{E}-06$ \\
\hline $\mathrm{Cm}-244$ & $6.07 \mathrm{E}-05$ & $3.91 \mathrm{E}-02$ & 8.96 & $4.54 \mathrm{E}-05$ & 5.87E-05 & $6.16 \mathrm{E}-05$ & $6.25 \mathrm{E}-05$ \\
\hline Totals & $\mathbf{M}$ & no/a & ko & 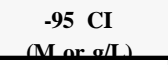 & $\begin{array}{c}-67 \mathrm{CI} \\
(\mathrm{M} / \mathrm{ar} / \mathrm{L}) \\
\end{array}$ & $\begin{array}{c}+67 \mathrm{CI} \\
\mathrm{M} \operatorname{cor} \sigma / L \\
\end{array}$ & $\begin{array}{c}+95 \text { CI } \\
(M ـ a / L / L \\
\end{array}$ \\
\hline $\mathrm{Pu}$ & $4.98 \mathrm{E}-02(\mathrm{~g} / \mathrm{L})$ & $\ldots$ & 7.35 & $2.72 \mathrm{E}-02$ & $4.68 \mathrm{E}-02$ & $5.11 \mathrm{E}-02$ & $5.24 \mathrm{E}-02$ \\
\hline $\mathrm{U}$ & $7.57 \mathrm{E}-03$ & $1.16 \mathrm{E}+03$ & 266 & $7.31 \mathrm{E}-03$ & $7.43 \mathrm{E}-03$ & $7.71 \mathrm{E}-03$ & $7.77 \mathrm{E}-03$ \\
\hline
\end{tabular}

*Unknowns in tank solids inventory are assigned by Tank Layering Model (TLM).

$\doteqdot$ Volume average for density, mass average Water wt $\%$ and TOC wt $\% \mathrm{C}$. 
HDW Model Rev. 4

\begin{tabular}{|c|c|c|c|c|c|c|c|}
\hline \multicolumn{8}{|c|}{ Single-Shell Tank 241-AX-103 } \\
\hline \multicolumn{8}{|c|}{ Total Inventory Estimate* } \\
\hline $\begin{array}{l}\text { Physical } \\
\text { Pronerties }\end{array}$ & & & & .95 CI & -67 CI & +67 CI & $+95 \mathrm{CL}$ \\
\hline Total Waste & $6.20 \mathrm{E}+05(\mathrm{~kg})$ & $(112 \mathrm{kgall}$ & & & & & \\
\hline Heat Load & $6.56(\mathrm{~kW})$ & $0224 \mathrm{E}+04 \mathrm{BTU} / \mathrm{hr}$ & & 582 & 6.33 & 670 & 681 \\
\hline Bulk Density $\dagger$ & $1.46(\mathrm{~g} / \mathrm{cc})$ & & & 142 & 145 & 148 & 148 \\
\hline & & & & & & & \\
\hline Water wt $\%$ t & 45.2 & & & 432 & 43.9 & 46.5 & 48.1 \\
\hline TOC wt $\% \mathrm{C}$ (wet) & 1.01 & & & 0580 & 0794 & 122 & \\
\hline $\begin{array}{c}\text { Chemical } \\
\text { Constituents }\end{array}$ & mole/L. & nnm & $\mathrm{ko}$ & $\begin{array}{c}-95 \mathrm{CI} \\
(\mathrm{mole} / \mathrm{I})\end{array}$ & $\begin{array}{c}-67 \mathrm{CI} \\
(\mathrm{mole} / \mathrm{L})\end{array}$ & $\begin{array}{c}+67 \mathrm{CI} \\
(\mathrm{mole} / \mathrm{I})\end{array}$ & $\begin{array}{c}+95 \mathrm{CI} \\
(\mathrm{mole} / \mathrm{I})\end{array}$ \\
\hline $\mathrm{Na}+$ & 10.1 & $1.59 \mathrm{E}+05$ & $9.87 \mathrm{E}+04$ & 025 & 071 & 105 & 107 \\
\hline $\mathrm{Al} 3+$ & 1.21 & $2.22 \mathrm{E}+04$ & $1.38 \mathrm{E}+04$ & 100 & 116 & 124 & 127 \\
\hline $\mathrm{Fe} 3+($ total $\mathrm{Fe})$ & 0.376 & $1.44 \mathrm{E}+04$ & $8.91 \mathrm{E}+03$ & 0.364 & 0.373 & 0.378 & 0.379 \\
\hline $\mathrm{Cr} 3+$ & $8.38 \mathrm{E}-02$ & $2.98 \mathrm{E}+03$ & $1.85 \mathrm{E}+03$ & $743 \mathrm{E}-02$ & $704 \mathrm{E}-02$ & $879 \mathrm{E}-02$ & $038 \mathrm{E}-02$ \\
\hline Bi3+ & $8.63 \mathrm{E}-04$ & 123 & 76.4 & $8.09 \mathrm{E}-04$ & $8.35 \mathrm{E}-04$ & $890 \mathrm{E}-04$ & $932 \mathrm{E}-04$ \\
\hline $\mathrm{La} 3+$ & $1.54 \mathrm{E}-05$ & 1.46 & 0.904 & $13 \mathrm{E}-05$ & $133 \mathrm{E}-05$ & $174 \mathrm{E}-05$ & $194 \mathrm{E}-05$ \\
\hline $\mathrm{Hg} 2+$ & $6.93 \mathrm{E}-06$ & 0.950 & 0.589 & $6.63 \mathrm{E}-06$ & $6.78 \mathrm{E}-06$ & $7.08 \mathrm{E}-06$ & $7.23 \mathrm{E}-06$ \\
\hline $\mathrm{Zr}$ (as $\mathrm{ZrO}(\mathrm{OH}) 2)$ & $1.07 \mathrm{E}-04$ & 6.68 & 4.14 & $9.90 \mathrm{E}-05$ & $1.02 \mathrm{E}-04$ & $111 \mathrm{E}-04$ & $1.15 \mathrm{E}-04$ \\
\hline $\mathrm{Pb} 2+$ & $9.39 \mathrm{E}-04$ & 133 & 82.5 & $722 \mathrm{E}-04$ & $828 \mathrm{E}-04$ & $105 \mathrm{E}-03$ & $116 \mathrm{E}-03$ \\
\hline $\mathrm{Ni} 2+$ & $1.09 \mathrm{E}-02$ & 439 & 272 & $3.81 \mathrm{E}-03$ & $799 \mathrm{E}-03$ & 124E-02 & $132 \mathrm{E}-02$ \\
\hline $\mathrm{Sr} 2+$ & 0 & 0 & 0 & & 0 & & \\
\hline Mn4+ & $3.20 \mathrm{E}-03$ & 120 & 74.5 & $275 \mathrm{E}-03$ & $207 \mathrm{E}-03$ & $342 \mathrm{E}-03$ & $364 \mathrm{E}-03$ \\
\hline $\mathrm{Ca} 2+$ & $5.03 \mathrm{E}-02$ & $1.38 \mathrm{E}+03$ & 854 & $2.05 \mathrm{E}-02$ & $3.55 \mathrm{E}-02$ & $5.76 \mathrm{E}-02$ & $6.18 \mathrm{E}-02$ \\
\hline $\mathrm{K}+$ & 4.67E- 02 & $1.25 \mathrm{E}+03$ & 775 & 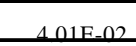 & $420 \mathrm{E}-02$ & $5-2 \mathrm{E}-02$ & $573 \mathrm{E}-02$ \\
\hline $\mathrm{OH}-$ & 7.95 & $9.24 \mathrm{E}+04$ & $5.73 \mathrm{E}+04$ & 699 & 768 & 8.11 & 826 \\
\hline NO3- & 3.05 & $1.29 \mathrm{E}+05$ & $8.02 \mathrm{E}+04$ & 289 & 297 & 3.13 & 3.21 \\
\hline NO2- & 1.81 & $5.68 \mathrm{E}+04$ & $3.53 \mathrm{E}+04$ & 146 & 160 & 203 & 200 \\
\hline CO32- & 0.399 & $1.64 \mathrm{E}+04$ & $1.02 \mathrm{E}+04$ & 0.363 & 0.381 & 0.417 & 0.429 \\
\hline PO43- & $6.50 \mathrm{E}-02$ & $4.22 \mathrm{E}+03$ & $2.62 \mathrm{E}+03$ & $560 \mathrm{E}-02$ & $5.99 \mathrm{E}-02$ & $6.90 \mathrm{E}-02$ & $7.43 \mathrm{E}-02$ \\
\hline SO42- & 0.216 & $1.42 \mathrm{E}+04$ & $8.81 \mathrm{E}+03$ & 0.175 & 0192 & 0244 & 0246 \\
\hline $\mathrm{Si}$ (as $\mathrm{SiO} 32-$ ) & 0.244 & $4.69 \mathrm{E}+03$ & $2.91 \mathrm{E}+03$ & $5.72 \mathrm{E}-02$ & 0.188 & 0.272 & 0295 \\
\hline $\mathrm{F}-$ & $4.69 \mathrm{E}-02$ & 610 & 378 & $398 \mathrm{E}-02$ & $428 \mathrm{E}-02$ & $516 \mathrm{E}-02$ & $585 \mathrm{E}-02$ \\
\hline $\mathrm{Cl}-$ & 0.169 & $4.10 \mathrm{E}+03$ & $2.55 \mathrm{E}+03$ & 0.146 & 0.156 & 0.174 & 0.179 \\
\hline C6H5O73- & $2.40 \mathrm{E}-02$ & $3.10 \mathrm{E}+03$ & $1.92 \mathrm{E}+03$ & $2.19 \mathrm{E}-02$ & $228 \mathrm{E}-02$ & $2.53 \mathrm{E}-02$ & $273 \mathrm{E}-02$ \\
\hline EDTA4- & $2.28 \mathrm{E}-02$ & $4.48 \mathrm{E}+03$ & $2.78 \mathrm{E}+03$ & $756 \mathrm{E}-02$ & 1 150E-02 & $306 \mathrm{E}-02$ & $382 \mathrm{E}-02$ \\
\hline HEDTA3- & $4.04 \mathrm{E}-02$ & $7.57 \mathrm{E}+03$ & $4.70 \mathrm{E}+03$ & $299 \mathrm{E}-03$ & $2.49 \mathrm{E}-02$ & $5.61 \mathrm{E}-02$ & $713 \mathrm{E}-02$ \\
\hline & & & & & & & \\
\hline glycolate- & $9.75 \mathrm{E}-02$ & $5.00 \mathrm{E}+03$ & $3.10 \mathrm{E}+03$ & $671 E_{-0} 0$ & 8 201E_ 02 & 0113 & 0.128 \\
\hline acetate- & $1.64 \mathrm{E}-02$ & 661 & 410 & $130 \mathrm{E}-02$ & $144 \mathrm{E}-02$ & $185 \mathrm{E}-02$ & $217 \mathrm{E}-02$ \\
\hline \begin{tabular}{|l} 
oxalate2- \\
\end{tabular} & $2.01 \mathrm{E}-05$ & 1.21 & 0.750 & $179 \mathrm{E}-05$ & $190 \mathrm{E}-05$ & $212 \mathrm{E}-05$ & $223 \mathrm{E}-05$ \\
\hline DBP & $1.88 \mathrm{E}-02$ & $2.70 \mathrm{E}+03$ & $1.67 \mathrm{E}+03$ & $1.56 \mathrm{E}-02$ & $170 \mathrm{E}-02$ & $2.07 \mathrm{E}-02$ & $2.36 \mathrm{E}-02$ \\
\hline butanol & $1.88 \mathrm{E}-02$ & 951 & 590 & $1.56 \mathrm{E}-02$ & $1.70 \mathrm{E}-02$ & $2.07 \mathrm{E}-02$ & $2.36 \mathrm{E}-02$ \\
\hline & & & & & & & \\
\hline NH3 & $7.54 \mathrm{E}-02$ & 876 & 543 & $5.42 \mathrm{E}-02$ & $6.49 \mathrm{E}-02$ & $8.63 \mathrm{E}-02$ & $271 \mathrm{E}-02$ \\
\hline $\mathrm{Fe}(\mathrm{CN}) 64$ & 0 & 0 & 0 & 0 & 0 & 0 & \\
\hline
\end{tabular}

*Unknowns in tank solids inventory are assigned by Tank Layering Model (TLM).

$\dagger$ Water wt $\%$ derived from the difference of density and total dissolved species. 
HDW Model Rev. 4

\begin{tabular}{|c|c|c|c|c|c|c|c|}
\hline \multicolumn{8}{|c|}{ Single-Shell Tank 241-AX-103 } \\
\hline \multicolumn{8}{|c|}{ Total Inventory Estimate* } \\
\hline $\begin{array}{l}\text { Physical } \\
\text { Pronerties }\end{array}$ & & & & $.95 \mathrm{CI}$ & $-67 \mathrm{CI}$ & $+67 \mathrm{CI}$ & $+95 \mathrm{CI}$ \\
\hline Total Waste & $6.20 \mathrm{E}+05(\mathrm{~kg})$ & $(112 \mathrm{kgal})$ & -.-- & - & -.-- & - & - \\
\hline Heat Load & $6.56(\mathrm{~kW})$ & $(2.24 \mathrm{E}+04 \mathrm{BTU} / \mathrm{hr})$ & $-\ldots$ & 5.82 & 6.33 & 6.70 & 6.81 \\
\hline Bulk Density† & $1.46(\mathrm{~g} / \mathrm{cc})$ & $\ldots$ & $\ldots$ & 1.42 & 1.45 & 1.48 & 1.48 \\
\hline & & & & & & & \\
\hline Water wt $\% \dagger$ & 45.2 & $\ldots$ & $\ldots$ & 43.2 & 43.9 & 46.5 & 48.1 \\
\hline TOC wt $\% \mathrm{C}$ (wet & 1.01 & --- & $-\ldots$ & 0.589 & 0.794 & 1.22 & 1.43 \\
\hline $\begin{array}{l}\text { Radiological } \\
\text { Conctituntc }\end{array}$ & Lل/L & Cilo & $\mathrm{Ci}_{\mathrm{i}}$ & 05 CL/Ci/L) & $67 \mathrm{CI} / \mathrm{Ci} / \mathrm{L})$ & $67 \mathrm{CI}(\mathrm{Ci} / \mathrm{I})$ & $\mathbf{L} \mathbf{C i}$ \\
\hline $\mathrm{H}-3$ & $1.88 \mathrm{E}-04$ & 0.129 & 79.8 & $1.32 \mathrm{E}-04$ & $1.32 \mathrm{E}-04$ & $2.04 \mathrm{E}-04$ & $2.23 \mathrm{E}-04$ \\
\hline C-14 & $2.98 \mathrm{E}-05$ & $2.04 \mathrm{E}-02$ & 12.6 & $1.80 \mathrm{E}-05$ & $1.80 \mathrm{E}-05$ & $3.10 \mathrm{E}-05$ & $3.22 \mathrm{E}-05$ \\
\hline $\mathrm{Ni}-59$ & $1.61 \mathrm{E}-05$ & $1.10 \mathrm{E}-02$ & 6.83 & $1.67 \mathrm{E}-06$ & $1.01 \mathrm{E}-05$ & $1.91 \mathrm{E}-05$ & $2.08 \mathrm{E}-05$ \\
\hline $\mathrm{Ni}-63$ & $1.62 \mathrm{E}-03$ & 1.10 & 685 & $1.65 \mathrm{E}-04$ & $1.01 \mathrm{E}-03$ & $1.91 \mathrm{E}-03$ & $2.08 \mathrm{E}-03$ \\
\hline $\mathrm{Co}-60$ & $3.81 \mathrm{E}-05$ & $2.60 \mathrm{E}-02$ & 16.2 & $2.46 \mathrm{E}-05$ & $2.46 \mathrm{E}-05$ & $3.98 \mathrm{E}-05$ & $7.32 \mathrm{E}-05$ \\
\hline Se-79 & $1.66 \mathrm{E}-05$ & $1.14 \mathrm{E}-02$ & 7.04 & $3.94 \mathrm{E}-06$ & $1.33 \mathrm{E}-05$ & $1.88 \mathrm{E}-05$ & $2.09 \mathrm{E}-05$ \\
\hline Sr-90 & 2.10 & $1.44 \mathrm{E}+03$ & $8.92 \mathrm{E}+05$ & 1.89 & 2.05 & 2.13 & 2.15 \\
\hline Y-90 & 2.11 & $1.44 \mathrm{E}+03$ & $8.93 \mathrm{E}+05$ & 1.89 & 2.05 & 2.13 & 2.15 \\
\hline Zr-93 & 7.72E-05 & $5.27 \mathrm{E}-02$ & 32.7 & $1.43 \mathrm{E}-05$ & $6.07 \mathrm{E}-05$ & $8.82 \mathrm{E}-05$ & $9.88 \mathrm{E}-05$ \\
\hline $\mathrm{Nb}-93 \mathrm{~m}$ & $5.75 \mathrm{E}-05$ & $3.93 \mathrm{E}-02$ & 24.4 & $1.32 \mathrm{E}-05$ & $4.60 \mathrm{E}-05$ & $6.53 \mathrm{E}-05$ & $7.27 \mathrm{E}-05$ \\
\hline Tc-99 & $2.25 \mathrm{E}-04$ & 0.154 & 95.4 & $1.81 \mathrm{E}-04$ & $2.01 \mathrm{E}-04$ & $2.52 \mathrm{E}-04$ & $2.88 \mathrm{E}-04$ \\
\hline$R=106$ & $5.39 \mathrm{E}-08$ & $3.68 \mathrm{E}-05$ & $2.28 \mathrm{E}-02$ & $2.22 \mathrm{E}-08$ & $4.57 \mathrm{E}-08$ & $5.94 \mathrm{E}-08$ & $6.47 \mathrm{E}-08$ \\
\hline$C d-113 m$ & 3.46E-04 & 0.237 & 147 & $7.69 \mathrm{E}-05$ & $2.48 \mathrm{E}-04$ & $4.12 \mathrm{E}-04$ & $4.76 \mathrm{E}-04$ \\
\hline Sb-125 & $1.71 \mathrm{E}-04$ & 0.117 & 72.4 & $1.12 \mathrm{E}-04$ & $1.12 \mathrm{E}-04$ & $1.78 \mathrm{E}-04$ & $1.86 \mathrm{E}-04$ \\
\hline Sn-126 & $2.58 \mathrm{E}-05$ & $1.76 \mathrm{E}-02$ & 10.9 & $6.78 \mathrm{E}-06$ & $2.09 \mathrm{E}-05$ & $2.91 \mathrm{E}-05$ & $3.23 \mathrm{E}-05$ \\
\hline I-129 & $4.35 \mathrm{E}-07$ & $2.97 \mathrm{E}-04$ & 0.184 & $3.50 \mathrm{E}-07$ & $3.88 \mathrm{E}-07$ & $4.87 \mathrm{E}-07$ & $5.58 \mathrm{E}-07$ \\
\hline Cs-134 & 3.79E- 06 & $2.59 \mathrm{E}-03$ & 1.61 & $2.64 \mathrm{E}-06$ & $3.20 \mathrm{E}-06$ & $4.38 \mathrm{E}-06$ & $4.96 \mathrm{E}-06$ \\
\hline Cs-137 & 0.275 & 188 & $1.17 \mathrm{E}+05$ & 0.212 & 0.243 & 0.307 & 0.338 \\
\hline $\mathrm{Ba}-137 \mathrm{~m}$ & 0.260 & 178 & $1.10 \mathrm{E}+05$ & 0.200 & 0.226 & 0.290 & 0.320 \\
\hline Sm-151 & $6.14 \mathrm{E}-02$ & 41.9 & $2.60 \mathrm{E}+04$ & $1.70 \mathrm{E}-02$ & $4.99 \mathrm{E}-02$ & $6.91 \mathrm{E}-02$ & $7.65 \mathrm{E}-02$ \\
\hline Eu-152 & $1.94 \mathrm{E}-05$ & $1.32 \mathrm{E}-02$ & 8.21 & $1.84 \mathrm{E}-05$ & $1.84 \mathrm{E}-05$ & $1.98 \mathrm{E}-05$ & $2.02 \mathrm{E}-05$ \\
\hline Eu-154 & 1.44E-03 & 0.987 & 612 & $5.52 \mathrm{E}-04$ & $6.23 \mathrm{E}-04$ & $2.00 \mathrm{E}-03$ & $2.53 \mathrm{E}-03$ \\
\hline Eu-155 & 1.39E-03 & 0.951 & 590 & $1.34 \mathrm{E}-03$ & $1.34 \mathrm{E}-03$ & $1.42 \mathrm{E}-03$ & $1.44 \mathrm{E}-03$ \\
\hline $\operatorname{Ra}-226$ & 1.03E-09 & 7.02E-07 & $4.36 \mathrm{E}-04$ & $6.35 \mathrm{E}-10$ & $9.26 \mathrm{E}-10$ & 1.10E-09 & $1.16 \mathrm{E}-09$ \\
\hline Ra-228 & $2.69 \mathrm{E}-07$ & $1.84 \mathrm{E}-04$ & 0.114 & $7.32 \mathrm{E}-08$ & $7.32 \mathrm{E}-08$ & $2.95 \mathrm{E}-07$ & $3.23 \mathrm{E}-07$ \\
\hline$\Delta c-227$ & 5.62E-09 & $3.84 \mathrm{E}-06$ & $2.38 \mathrm{E}-03$ & $3.34 \mathrm{E}-09$ & $5.03 \mathrm{E}-09$ & $6.02 \mathrm{E}-09$ & $6.40 \mathrm{E}-09$ \\
\hline $\mathrm{Pa}-231$ & $1.43 \mathrm{E}-08$ & $9.75 \mathrm{E}-06$ & $6.05 \mathrm{E}-03$ & $3.25 \mathrm{E}-09$ & $1.10 \mathrm{E}-08$ & $1.65 \mathrm{E}-08$ & $1.86 \mathrm{E}-08$ \\
\hline Th-220 & $6.24 \mathrm{E}-09$ & $4.27 \mathrm{E}-06$ & $2.65 \mathrm{E}-03$ & $1.72 \mathrm{E}-09$ & $1.72 \mathrm{E}-09$ & $6.81 \mathrm{E}-09$ & 7.42E- 09 \\
\hline Th-232 & $2.89 \mathrm{E}-08$ & $1.98 \mathrm{E}-05$ & $1.23 \mathrm{E}-02$ & 4.73E-09 & 4.73E- 09 & $3.56 \mathrm{E}-08$ & $4.19 \mathrm{E}-08$ \\
\hline U-232 & $8.05 \mathrm{E}-07$ & $5.50 \mathrm{E}-04$ & 0.341 & $6.21 \mathrm{E}-07$ & $6.95 \mathrm{E}-07$ & $9.31 \mathrm{E}-07$ & $1.06 \mathrm{E}-06$ \\
\hline U-233 & $3.09 \mathrm{E}-06$ & $2.11 \mathrm{E}-03$ & 1.31 & $2.38 \mathrm{E}-06$ & $2.66 \mathrm{E}-06$ & $3.57 \mathrm{E}-06$ & $4.08 \mathrm{E}-06$ \\
\hline U-234 & $5.24 \mathrm{E}-07$ & $3.58 \mathrm{E}-04$ & 0.222 & $5.07 \mathrm{E}-07$ & $5.17 \mathrm{E}-07$ & $5.31 \mathrm{E}-07$ & $5.36 \mathrm{E}-07$ \\
\hline $\mathrm{U}-235$ & 2.08E-08 & $1.42 \mathrm{E}-05$ & $8.81 \mathrm{E}-03$ & $2.01 \mathrm{E}-08$ & $2.05 \mathrm{E}-08$ & $2.11 \mathrm{E}-08$ & $2.13 \mathrm{E}-08$ \\
\hline U-236 & $1.68 \mathrm{E}-08$ & $1.15 \mathrm{E}-05$ & $7.11 \mathrm{E}-03$ & $1.63 \mathrm{E}-08$ & $1.66 \mathrm{E}-08$ & $1.70 \mathrm{E}-08$ & $1.72 \mathrm{E}-08$ \\
\hline U-238 & $7.20 \mathrm{E}-07$ & $4.92 \mathrm{E}-04$ & 0.305 & 7.05E-07 & 7.14E-07 & 7.27E- 07 & 7.51E-07 \\
\hline $\mathrm{Nn}-237$ & 7.56E-07 & $5.16 \mathrm{E}-04$ & 0.320 & $6.12 \mathrm{E}-07$ & $6.77 \mathrm{E}-07$ & $8.43 \mathrm{E}-07$ & 9.62E-07 \\
\hline Pu-238 & $1.28 \mathrm{E}-05$ & $8.78 \mathrm{E}-03$ & 5.45 & $1.07 \mathrm{E}-05$ & $1.23 \mathrm{E}-05$ & $1.32 \mathrm{E}-05$ & $1.36 \mathrm{E}-05$ \\
\hline Pu-239 & $3.40 \mathrm{E}-04$ & 0.232 & 144 & $2.85 \mathrm{E}-04$ & $3.26 \mathrm{E}-04$ & $3.50 \mathrm{E}-04$ & $3.59 \mathrm{E}-04$ \\
\hline $\mathrm{Pu}-240$ & 6.43E-05 & $4.39 \mathrm{E}-02$ & 27.3 & $5.37 \mathrm{E}-05$ & $6.16 \mathrm{E}-05$ & $6.61 \mathrm{E}-05$ & $6.79 \mathrm{E}-05$ \\
\hline $\mathrm{Pu}-241$ & 9.13E-04 & 0.624 & 387 & $7.61 \mathrm{E}-04$ & $8.73 \mathrm{E}-04$ & $9.39 \mathrm{E}-04$ & $9.64 \mathrm{E}-04$ \\
\hline $\mathrm{Pu}-242$ & $5.26 \mathrm{E}-09$ & $3.59 \mathrm{E}-06$ & $2.23 \mathrm{E}-03$ & $4.38 \mathrm{E}-09$ & 5.03E- 09 & $5.41 \mathrm{E}-09$ & $5.56 \mathrm{E}-09$ \\
\hline$A m-241$ & $5.25 \mathrm{E}-04$ & 0.359 & 222 & $3.35 \mathrm{E}-04$ & $4.75 \mathrm{E}-04$ & $5.58 \mathrm{E}-04$ & $5.89 \mathrm{E}-04$ \\
\hline Am-243 & $1.65 \mathrm{E}-08$ & $1.13 \mathrm{E}-05$ & $6.99 \mathrm{E}-03$ & $1.07 \mathrm{E}-08$ & $1.50 \mathrm{E}-08$ & $1.75 \mathrm{E}-08$ & $1.85 \mathrm{E}-08$ \\
\hline $\mathrm{Cm}-242$ & $5.56 \mathrm{E}-07$ & $3.80 \mathrm{E}-04$ & 0.236 & $5.17 \mathrm{E}-07$ & $5.17 \mathrm{E}-07$ & $5.72 \mathrm{E}-07$ & $5.87 \mathrm{E}-07$ \\
\hline $\mathrm{Cm}-243$ & 4.46E-08 & $3.05 \mathrm{E}-05$ & $1.89 \mathrm{E}-02$ & $4.10 \mathrm{E}-08$ & $4.10 \mathrm{E}-08$ & $4.61 \mathrm{E}-08$ & $4.75 \mathrm{E}-08$ \\
\hline $\mathrm{Cm}-244$ & 1.13E-06 & 7.73E-04 & 0.479 & 4.97E-07 & $9.66 \mathrm{E}-07$ & $1.24 \mathrm{E}-06$ & $1.35 \mathrm{E}-06$ \\
\hline Totals & $\mathbf{M}$ & no/o & $\mathrm{ko}$ & $\begin{array}{c}-95 \text { CI } \\
\text { M-ar } \mathrm{d} / \mathrm{L} \text {. }\end{array}$ & $\begin{array}{c}-67 \mathrm{CI} \\
(\mathrm{M} / \mathrm{ar} / \mathrm{L}) \\
\end{array}$ & $\begin{array}{c}+67 \mathrm{CI} \\
(\mathrm{M} / \mathrm{ar} / \mathrm{L})\end{array}$ & $\begin{array}{c}+95 \text { CI } \\
(\mathrm{M} \text { or } \mathrm{o} / \mathrm{L})\end{array}$ \\
\hline $\mathrm{Pu}$ & $5.58 \mathrm{E}-03(\mathrm{~g} / \mathrm{L})$ & $\ldots$ & 2.37 & $4.64 \mathrm{E}-03$ & $5.34 \mathrm{E}-03$ & $5.74 \mathrm{E}-03$ & $5.90 \mathrm{E}-03$ \\
\hline $\mathrm{U}$ & $5.88 \mathrm{E}-03$ & 957 & 594 & $5.69 \mathrm{E}-03$ & $5.80 \mathrm{E}-03$ & $5.97 \mathrm{E}-03$ & $6.04 \mathrm{E}-03$ \\
\hline
\end{tabular}

*Unknowns in tank solids inventory are assigned by Tank Layering Model (TLM).

$\dagger$ Volume average for density, mass average Water wt $\%$ and TOC wt $\% \mathrm{C}$. 
HDW Model Rev. 4

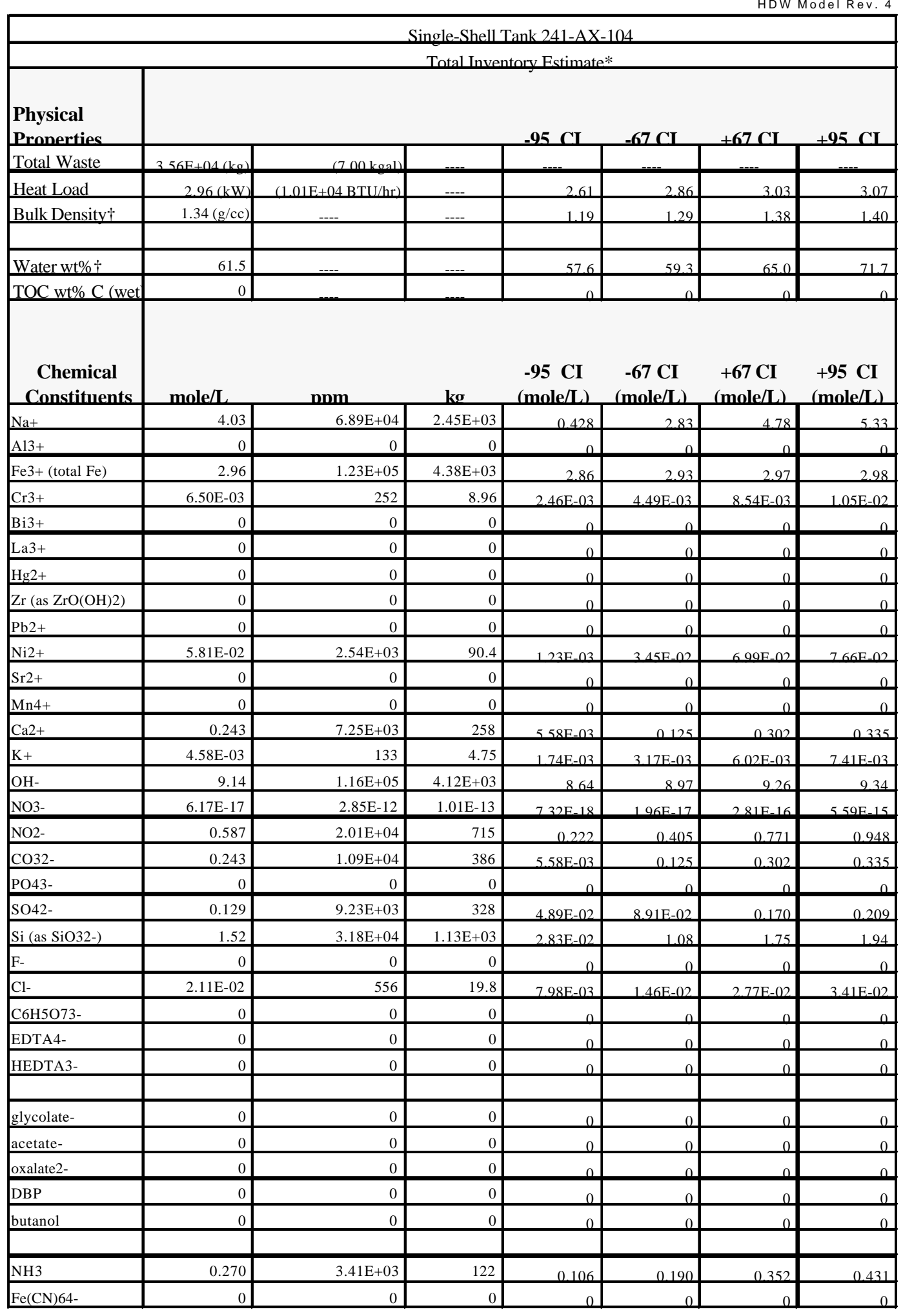

*Unknowns in tank solids inventory are assigned by Tank Layering Model (TLM).

$\dagger$ Water wt $\%$ derived from the difference of density and total dissolved species. 
HDW Model Rev. 4

\begin{tabular}{|c|c|c|c|c|c|c|c|}
\hline \multicolumn{8}{|c|}{ Single-Shell Tank 241-AX-104 } \\
\hline & \multicolumn{7}{|c|}{ Total Inventory Estimate* } \\
\hline $\begin{array}{l}\text { Physical } \\
\text { Pronerties }\end{array}$ & & & & $-95 \mathrm{CL}$ & $-67 \mathrm{CL}$ & $+67 \mathrm{CL}$ & $+95 \mathrm{CL}$ \\
\hline Total Waste & $3.56 \mathrm{E}+04(\mathrm{~kg})$ & $(7.00 \mathrm{kgal})$ & - & $\ldots$ & $-\ldots$ & $-\cdots$ & - \\
\hline Heat Load & $206(\mathrm{~kW}$ & $(101 \mathrm{E}+04 \mathrm{BT} U / \mathrm{hr})$ & & 261 & 286 & 303 & 307 \\
\hline Bulk Densityt & $134(\mathrm{~g} / \mathrm{de})$ & & & 110 & 120 & 138 & 140 \\
\hline Water wt $\%+$ & 61.5 & $\ldots$ & $\ldots$ & 576 & 593 & 650 & 717 \\
\hline TOC wt $\% \mathrm{C}$ (wet & 0 & $\ldots$ & $\ldots$ & 0 & 0 & 0 & 0 \\
\hline $\begin{array}{l}\text { Radiological } \\
\text { Constituents }\end{array}$ & $\mathrm{Ci} / \mathrm{L}$ & $\mu \mathrm{Ci} / \mathrm{g}$ & $\mathrm{Ci}$ & $\begin{array}{l}-95 \mathrm{CI} \\
(\mathrm{Ci} / \mathrm{L}) \\
\end{array}$ & $\begin{array}{l}-67 \mathrm{CI} \\
(\mathrm{Ci} / \mathrm{L})\end{array}$ & $\begin{array}{l}+67 \mathrm{CI} \\
(\mathrm{Ci} / \mathrm{L}) \\
\end{array}$ & $\begin{array}{c}+95 \mathrm{CI} \\
(\mathrm{Ci} / \mathrm{L}) \\
\end{array}$ \\
\hline $\mathrm{H}-3$ & $128 \mathrm{E}-04$ & $9.50 \mathrm{E}-02$ & 3.38 & $1.76 \mathrm{E}-05$ & $596 \mathrm{E}-05$ & $222 \mathrm{E}-04$ & $3.38 \mathrm{E}-04$ \\
\hline C-14 & $238 \mathrm{E}-05$ & 1 77E- 02 & 0.630 &  & $164 \mathrm{E}-05$ & 3 12E-05 & $384 \mathrm{E}-05$ \\
\hline $\mathrm{Ni}-59$ & 1 18E_OA & $877 E_{-}-02$ & 3.12 & $240 E_{-} 06$ & $700 E_{-} 05$ & 1 LEE_OA & 1 _5E_-04 \\
\hline $\mathrm{Ni}-63$ & $1 \mathrm{1} 8 \mathrm{E}-\mathrm{C} 2$ & 881 & 313 & $250 \mathrm{E}-04$ & $703 \mathrm{E}-03$ & $142 \mathrm{E}-\mathrm{O} 2$ & $156 \mathrm{E}-02$ \\
\hline $\mathrm{C} 0-60$ & $3.28 \mathrm{E}-05$ & $2.44 \mathrm{E}-02$ & 0.868 & $1.24 \mathrm{E}-05$ & $2.26 \mathrm{E}-05$ & $4.30 \mathrm{E}-05$ & $3.17 \mathrm{E}-04$ \\
\hline $\mathrm{Se}-79$ & $1 \mathrm{de-04}$ & $8.30 \mathrm{E}-02$ & 2.95 & $1.02 \mathrm{E}-05$ & $8.53 \mathrm{E}-05$ & $1.29 \mathrm{E}-04$ & $1.47 \mathrm{E}-04$ \\
\hline $\mathrm{Sr}-90$ & 162 & $120 \mathrm{E}+04$ & $4.28 \mathrm{E}+05$ & 145 & 157 & 164 & 165 \\
\hline$Y-90$ & 162 & $120 \mathrm{E}+04$ & $4.29 \mathrm{E}+05$ & 145 & 157 & 164 & 165 \\
\hline $\mathrm{Zr}-93$ & 5 12F_- 04 & 0381 & 13.6 & 0 11E_06 & $381 E_{-} \Omega 4$ & $602 E_{-} 04$ & 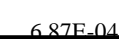 \\
\hline $\mathrm{Nb}-93 \mathrm{~m}$ & $3.84 \mathrm{E}-04$ & 0.286 & 10.2 & $3.00 \mathrm{E}-05$ & $293 \mathrm{E}-04$ & $4.47 \mathrm{E}-04$ & $5.07 \mathrm{E}-04$ \\
\hline Tc-99 & $169 \mathrm{E}-04$ & 0.125 & 4.47 & $6.38 \mathrm{E}-0.5$ & $1.16 \mathrm{E}-04$ & $2.21 \mathrm{E}-04$ & $2.72 \mathrm{E}-04$ \\
\hline Ru-106 & $382 \mathrm{E}-07$ & $284 \mathrm{E}-04$ & $1.01 \mathrm{E}-02$ & $129 \mathrm{E}-07$ & $316 \mathrm{E}-07$ & $427 \mathrm{E}-07$ & $4.70 \mathrm{E}-07$ \\
\hline $\mathrm{Cd}-113 \mathrm{~m}$ & $220 \mathrm{E}_{-} 03$ & 163 & 58.2 & $441 \mathrm{E}_{-} 05$ & $141 \mathrm{E}_{-} 03$ & $273 \mathrm{E}-03$ & $325 \mathrm{E}_{-} 03$ \\
\hline $\mathrm{Sh}-125$ & $147 \mathrm{E}_{-} \mathrm{\Omega} 4$ & مــــــــ & 3.90 & 5 57E-05 & $102 \mathrm{E}_{-} \mathrm{O} 4$ & 1 Q23E-04 & $238 \mathrm{E}-04$ \\
\hline $\mathrm{Sn}-126$ & $1.74 \mathrm{E}-04$ & 0.129 & 4.61 & $2.20 \mathrm{E}-0.0$ & $1.35 \mathrm{E}-04$ & $2.01 \mathrm{E}-04$ & $2.27 \mathrm{E}-04$ \\
\hline $\mathrm{I}-129$ & $326 \mathrm{E}-07$ & $2,43 \mathrm{E}-04$ & 8.64E-03 & $123 \mathrm{E}-07$ & $225 \mathrm{E}-07$ & $4.28 \mathrm{E}-07$ & $5,27 \mathrm{E}-07$ \\
\hline Cs-134 & $781 \mathrm{E}_{-} \mathrm{O} 6$ & $581 \mathrm{E}_{-} 03$ & 0.207 & $206 \mathrm{E}-06$ & 5 39E-06 & كم-03E & $126 \mathrm{E}-05$ \\
\hline Cs- 137 & 0621 & 463 & $1.65 \mathrm{E}+04$ & 0235 & 0420 & 0.816 & ممـــ \\
\hline $\mathrm{Ba}-137 \mathrm{~m}$ & 0.588 & 438 & $1.56 \mathrm{E}+04$ & 0223 & 0.406 & 0772 & مكوفم \\
\hline $\mathrm{Sm}-151$ & 0.416 & 309 & $1.10 \mathrm{E}+04$ & $6.12 \mathrm{E}-02$ & 0.324 & 0.478 & 0.538 \\
\hline Eu-152 & $1.27 \mathrm{E}-04$ & $2,44 \mathrm{E}-02$ & 3.36 & $125 \mathrm{E}-04$ & $126 \mathrm{E}-04$ & $128 \mathrm{E}-04$ & $1.29 \mathrm{E}-04$ \\
\hline Eu-154 & $731 E_{-} 03$ & 544 & 194 & $236 \mathrm{E}-04$ & $7 \mathrm{AGE}-04$ & 1 18E_ 02 & 1 G1E_ 02 \\
\hline Eu-155 & $045 \mathrm{E}_{-} \mathrm{O} 3$ & 703 & 250 & $028 E_{-} 03$ & $037 \mathrm{E}_{-} \mathrm{O} 3$ & $0 \leq 55 E_{-} 03$ & O 64E_ 03 \\
\hline Ra-226 & 7 30E_00 & 5 51E_a6 & $1.96 \mathrm{E}-04$ & $426 \mathrm{E}_{2} 0 \mathrm{O}$ &  & $706 \mathrm{E}-00$ & 8 SـAE_ \\
\hline Ra-228 & $6.69 \mathrm{E}-14$ & $4.98 \mathrm{E}-11$ & $1.77 \mathrm{E}-09$ & $6.57 \mathrm{E}-14$ & $6.63 \mathrm{E}-14$ & $6.76 \mathrm{E}-14$ & $6.82 \mathrm{E}-14$ \\
\hline Ac-227 & $3.99 \mathrm{E}-08$ & $2.97 \mathrm{E}-05$ & $1.06 \mathrm{E}-03$ & $2.17 \mathrm{E}-08$ & $3.52 \mathrm{E}-08$ & $4.31 \mathrm{E}-08$ & $4.62 \mathrm{E}-08$ \\
\hline $\mathrm{Pa}-231$ & 8 98E-08 & $668 \mathrm{E}-05$ & $2.38 \mathrm{E}-03$ & $167 E_{-} 09$ & $636 \mathrm{E}-08$ & $108 E-07$ & $125 \mathrm{E}_{-} 07$ \\
\hline Th-229 & لـ & 7 77E-09 & $2.77 \mathrm{E}-07$ & $103 E_{-11}$ & $104 \mathrm{E}-11$ & $106 \mathrm{E}-11$ & 1 م6E-11 \\
\hline Th-232 & $604 \mathrm{E}-15$ & $449 \mathrm{E}-12$ & $1.60 \mathrm{E}-10$ & $228 \mathrm{E}-15$ & $4-17 E_{-}-15$ & $793 \mathrm{E}-15$ & $075 \mathrm{E}-15$ \\
\hline $\mathrm{U}-232$ & $8.39 \mathrm{E}-12$ & $6.24 \mathrm{E}-09$ & $2.22 \mathrm{E}-07$ & $3.18 \mathrm{E}-12$ & $5.79 \mathrm{E}-12$ & $1.10 \mathrm{E}-11$ & $136 \mathrm{E}-11$ \\
\hline $\mathrm{U}-233$ & $198 \mathrm{E}-13$ & $147 \mathrm{E}-10$ & $5.24 \mathrm{E}-09$ & $7.49 \mathrm{E}-14$ & $137 \mathrm{E}-13$ & $260 \mathrm{E}-13$ & $320 \mathrm{E}-13$ \\
\hline U-234 & $103 E_{-} 07$ & $770 \mathrm{E}-05$ & $2.74 \mathrm{E}-03$ & $301 E_{-0} 8$ & $714 \mathrm{E}_{-} \mathrm{O} 8$ & $136 \mathrm{E}-07$ & 1 67E_-07 \\
\hline U-235 & $431 \mathrm{E}-09$ & $321 \mathrm{E}-06$ & $1.14 \mathrm{E}-04$ & $163 \mathrm{E}_{-} 09$ & $298 E_{-} 09$ & $567 \mathrm{E}-09$ & $607 \mathrm{E}_{0} 09$ \\
\hline U-236 & $282 E_{-} 09$ & 2 10E-O6 & 7.47E-05 & $107 \mathrm{E}_{-09}$ & $195 E_{-} 00$ & $371 \mathrm{E}-09$ & $4.56 \mathrm{E}-00$ \\
\hline U-238 & $1.01 \mathrm{E}-07$ & $7.49 \mathrm{E}-05$ & $2.67 \mathrm{E}-03$ & $3.81 \mathrm{E}-08$ & $6.95 \mathrm{E}-08$ & $1.32 \mathrm{E}-07$ & $163 \mathrm{E}-07$ \\
\hline $\mathrm{Np}-237$ & $3.60 \mathrm{E}-07$ & $2.68 \mathrm{E}-04$ & $9.54 \mathrm{E}-03$ & $1.36 \mathrm{E}-07$ & $2.49 \mathrm{E}-07$ & $4.73 \mathrm{E}-07$ & $5.82 \mathrm{E}-07$ \\
\hline $\mathrm{Pu}-238$ & $042 E_{-} 05$ & 7 ONE_ & 2.50 & $772 E_{-} 05$ & $809 E_{-} 05$ & $073 E_{-05}$ & 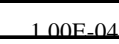 \\
\hline $\mathrm{Pu}$-239 & $244 \mathrm{E}_{2} \mathrm{O} 3$ & 182 & 64.7 & $2 \mathrm{ONE} \mathrm{E}_{2}$ & $233 \mathrm{E}_{-} \mathrm{O} 3$ & $252 \mathrm{~F}_{-} \mathrm{O} 3$ & $260 E_{-} 03$ \\
\hline
\end{tabular}




\section{Appendix B}

Suggested Approach for

First Determination Assessment Plan 


\section{Appendix B}

\section{Suggested Approach for First Determination Assessment}

This chapter presents a basic approach for an assessment-monitoring program, as required by 40 CFR 265.93(a). The assessment program must be capable of determining whether dangerous waste or dangerous waste constituents from the facility have compromised groundwater, and if so, to determine the concentration, the rate and the extent of migration in the groundwater (40 CFR 265.93(d)).

If an indicator parameter at a downgradient well exceeds the initial background value, an assessment plan will be prepared and submitted to Washington State Department of Ecology (Ecology). The plan will include the:

- description of the approach to determine if dangerous waste or dangerous waste constituents from the facility have entered the groundwater or if the exceedance was caused by other sources (false positive rationale)

- description of the investigative approach to fully characterize rate and extent of contaminant migration

- number, locations, and depths of wells in the monitoring network

- sampling and analytical methods used

- data evaluation procedures

- an implementation schedule.

A generic flowchart for the assessment program is presented in Figure B.1 with a proposed plan outline provided in Table B.1.

The first determination is conducted as soon as technically feasible and a report of the findings sent to Ecology. If a further determination investigation is required based on the results of the first determination, a detailed assessment plan appropriate to Waste Management Area (WMA) A-AX will be developed and updated annually as required by 40 CFR 265.94(b).

\section{B.1}


Table B.1. Contents of Proposed Groundwater Quality Assessment Monitoring Plan

\begin{tabular}{|c|c|}
\hline $\begin{array}{ll}1.0 & \text { Introduction } \\
1.1 & \text { Objectives } \\
1.2 & \text { Approach } \\
1.3 & \text { Scope and Organization }\end{array}$ & $\begin{array}{ll}\text { 4.0 Assessment Monitoring Program } \\
\text { 4.1 Monitoring Network } \\
\text { 4.2 Groundwater Flow Direction Rate } \\
\text { 4.3 Dangerous Waste Constituents } \\
\text { 4.4 Investigative Tasks } \\
\text { 5.0 Assessment Schedule and Budget }\end{array}$ \\
\hline $\begin{array}{ll}2.0 \text { Background Information } \\
\text { 2.1 Facility Description } \\
2.2 \text { Facility Operational History } \\
2.2 .1 \text { Past Operational Tank History } \\
2.2 .2 \text { Tank Leak History } \\
2.2 .3 \text { Present Operational History } \\
2.3 \text { Waste Characteristics } \\
\text { 2.3.1 PUREX Primary Process } \\
2.4 \text { Geology } \\
\text { 2.4.1 Site Specific Stratigraphy } \\
\text { 2.4.2 Aquifer properties } \\
2.5 \text { Groundwater Chemistry }\end{array}$ & \\
\hline $\begin{array}{l}\text { 3.0 Conceptual Model } \\
\text { 3.1 Contaminant Sources } \\
\text { 3.2 Driving Forces } \\
\text { 3.3 Migration Pathways }\end{array}$ & $\begin{array}{l}6.0 \text { References } \\
\text { Appendix A-Sampling and Analysis Plan } \\
\text { Appendix B-As-Built Diagrams of Single-Shell } \\
\text { Tank System Waste Management Area A-AX } \\
\text { Groundwater Monitoring Wells }\end{array}$ \\
\hline
\end{tabular}




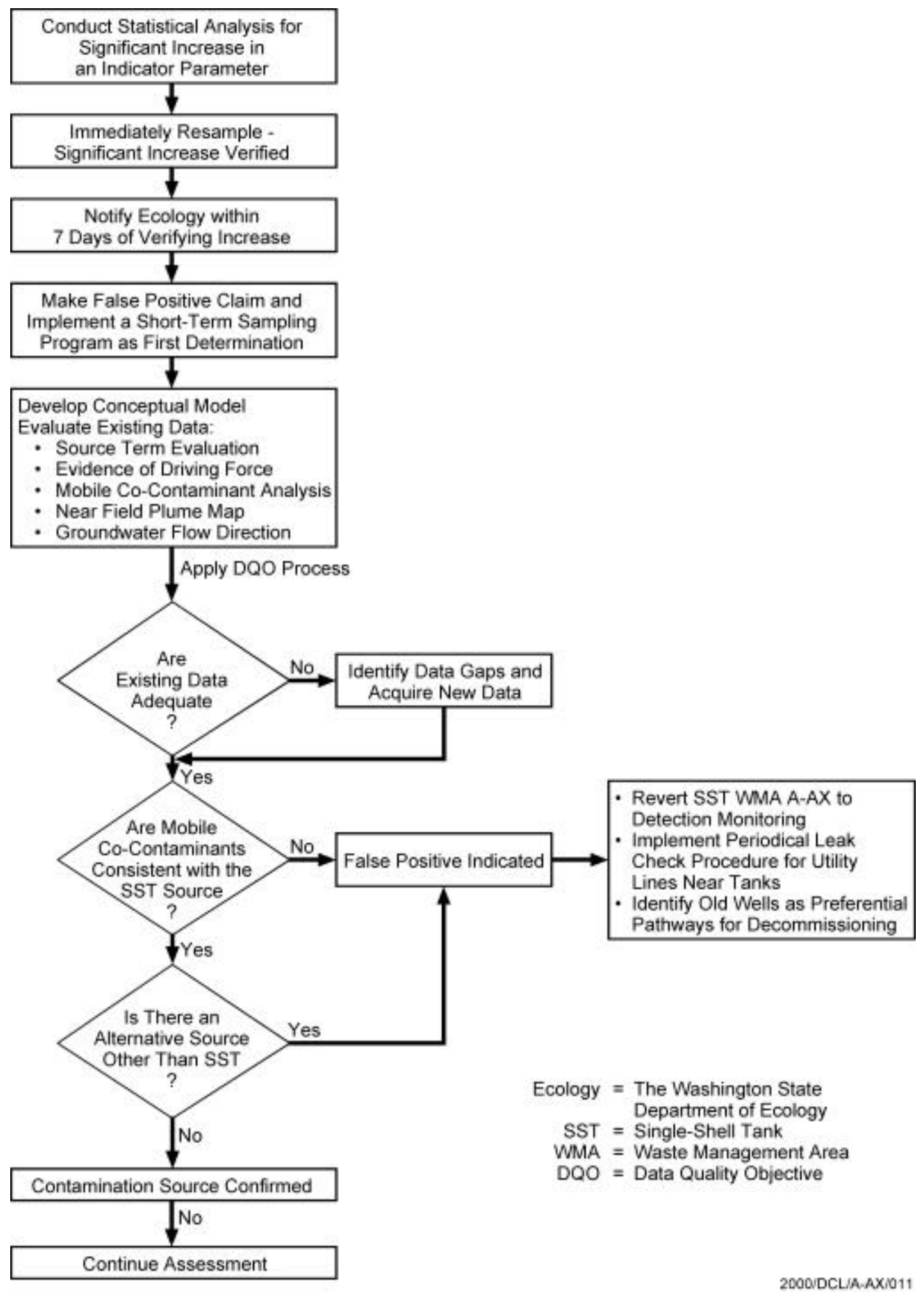

Figure B.1. Flow Chart for First Determination Groundwater Quality Assessment Monitoring Program 


\section{Appendix C}

As-Built Diagrams of Single-Shell Tank System Waste Management Area A-AX Groundwater Monitoring Wells 


\section{Appendix C}

\section{As-Built Diagrams of Single-Shell Tank System Waste Management Area A-AX Groundwater Monitoring Wells}

The following as-built diagrams illustrate specifications of well construction and the general

lithologic information recorded during the drilling of each well. All depths and dimensions are in feet and inches, as they were recorded during the drilling and construction of the wells. Included are the six wells in the current A-AX, and additional candidate wells that could be added to the network if assessment monitoring becomes necessary. 


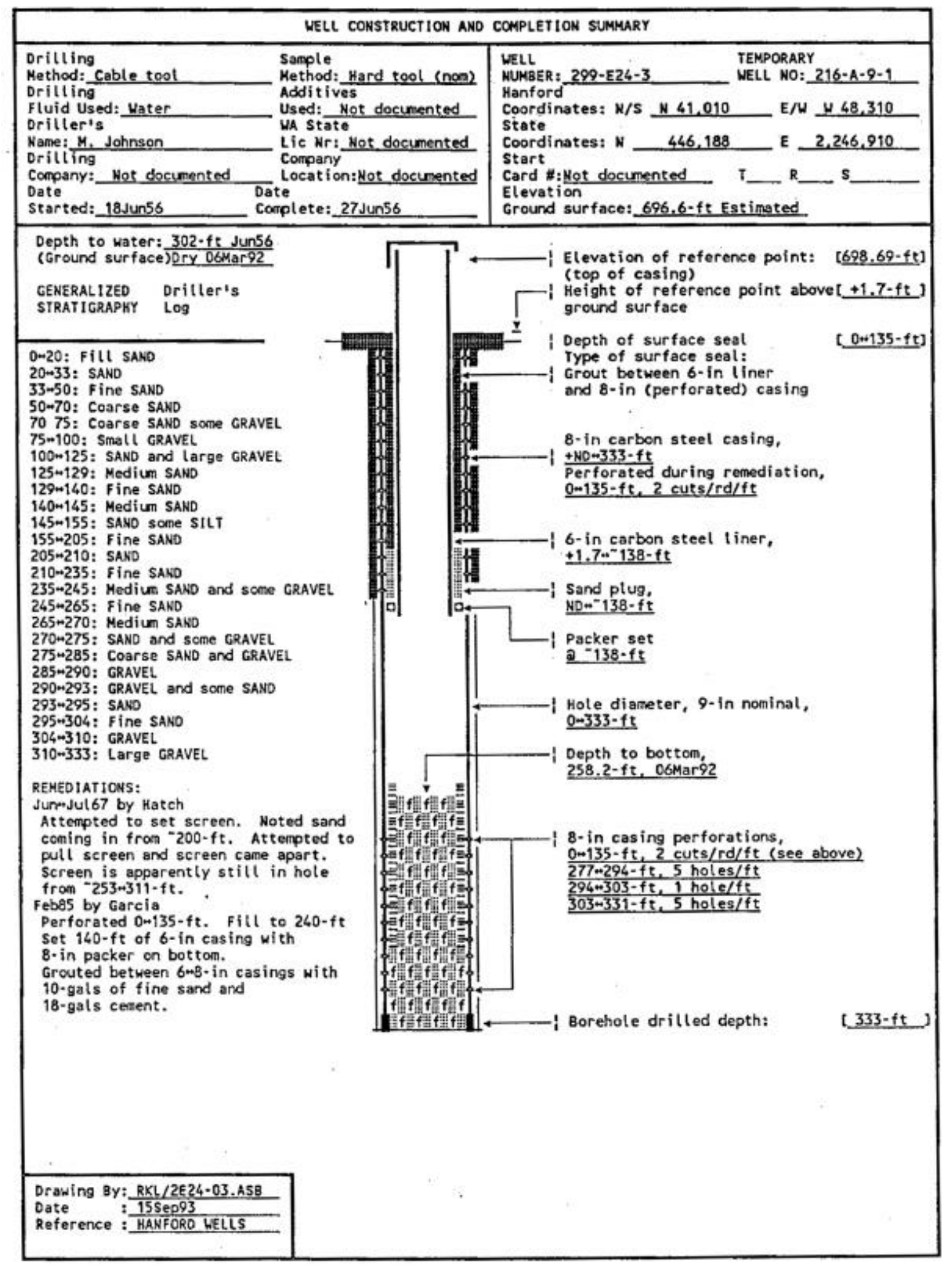




\section{SUMMARY OF CONSTRUCTION DATA AND FIELD OBSERVATIONS RESOURCE PROTECTION WELL - 299-E24-3}

\begin{tabular}{|c|}
\hline $\begin{array}{l}\text { WELL DESIGNATION } \\
\text { RCRA FACILITY } \\
\text { CERCLA UNIT } \\
\text { HANFORD COORDIMATES } \\
\text { LANBERT COORDIMATES } \\
\text { DATE DRILLED } \\
\text { DEPTH DRILLED (GS) } \\
\text { MEASURED DEPTH (GS) } \\
\text { DEPTH TO WATER (GS) }\end{array}$ \\
\hline CASING DIAMETER \\
\hline $\begin{array}{l}\text { ELEV TOP CASING } \\
\text { ELEV GROUND SURFACE } \\
\text { PERFORATED INTERVAL }\end{array}$ \\
\hline $\begin{array}{l}\text { SCREENED INTERVAL } \\
\text { COMMENTS }\end{array}$ \\
\hline $\begin{array}{l}\text { AVAILABLE LOGS } \\
\text { TV SCAN COMMENTS } \\
\text { DATE EVALUATED } \\
\text { EVAL RECCMMENDATION } \\
\text { LISTED USE } \\
\text { CURRENT USER } \\
\text { PUMP TYPE } \\
\text { MAINTENANCE }\end{array}$ \\
\hline
\end{tabular}

299-E24-3

Not applicable

200 Aggregate Area Management Study

N 41,010.8 W 48,310.4 [02Mar88-200E]

N 446,188 E $2,246,910$ [HANCONV]

Jun56

$333 . \mathrm{ft}$

258.2-ft, 06Mar92

$302-\mathrm{ft}$, Mays7;

Dry at 258.2-ft, 06Mar92

8-in, carbon steel, 0 m333-ft;

6-in, carbon steel, +1.7*-238-ft

698.33- $\mathrm{ft}$, [02Mar88-200E]

696.6-ft, Estimated

$277+331-\mathrm{ft}$;

Remediation $0+135-\mathrm{ft}$

-253-311-ft

FIELD INSPECTION, O6Har92,

6-in carbon steel casing. Capped, not locked

No pad, no posts. no permanent identification.

Not in radiation zone.

Driller

Hot appl icable

Not applicable

Not applicable

Water levels measured 09Sep65-07Apr67;

None documented

None documented 
WELL CONSTRUCTION AND COMPLETION SUMMARY

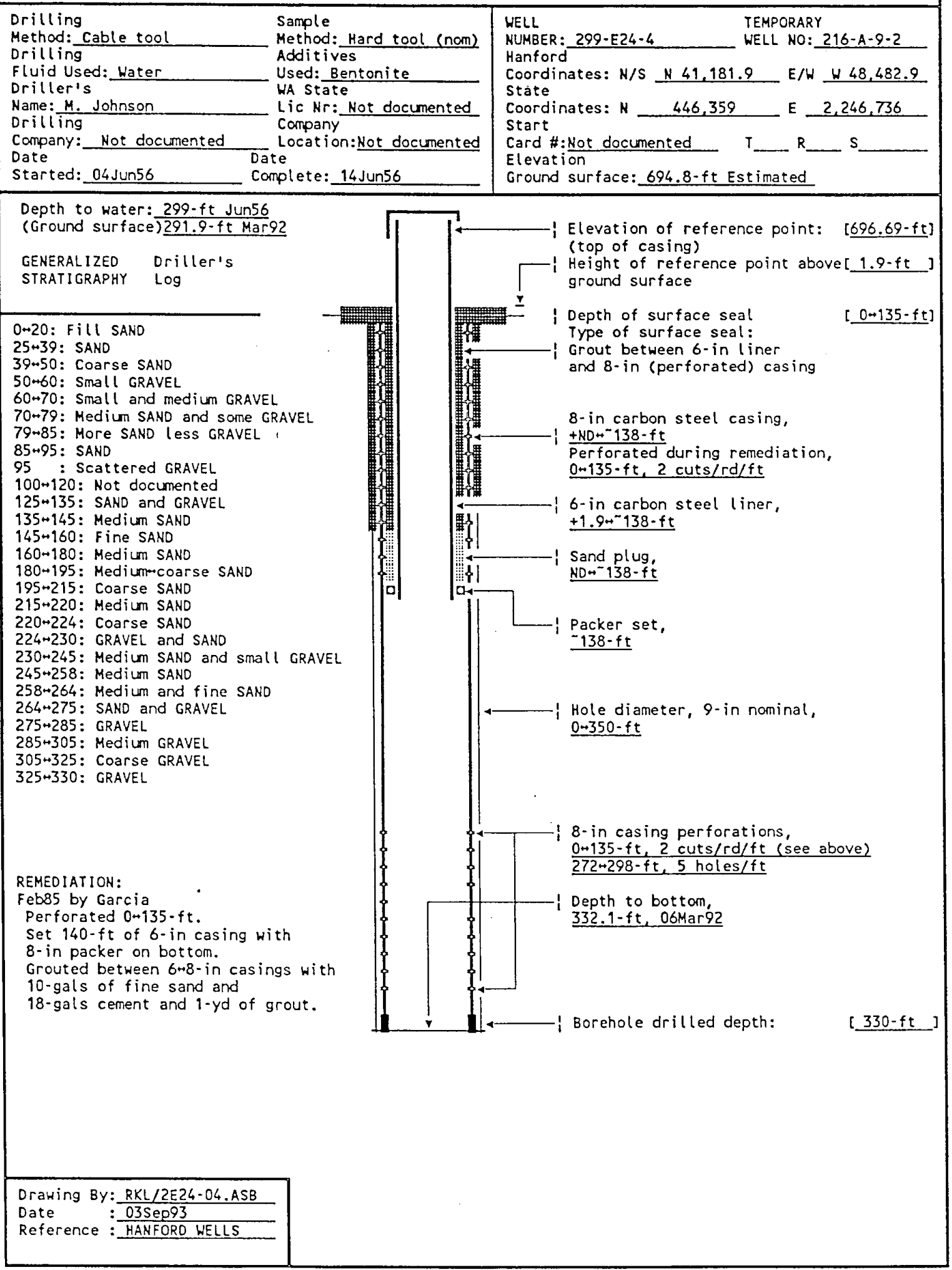




\section{SUMMARY OF CONSTRUCTION DATA AND FIELD OBSERVATIONS RESOURCE PROTECTION WELL - 299-E24-4}

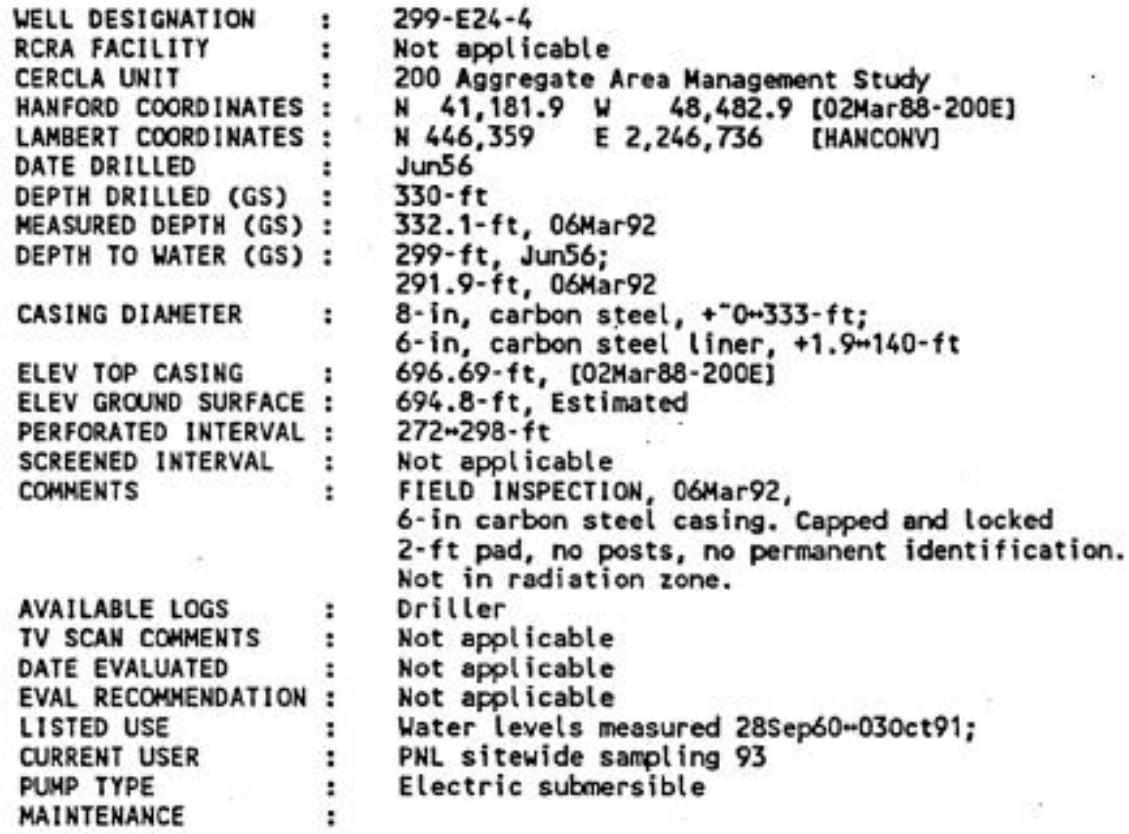




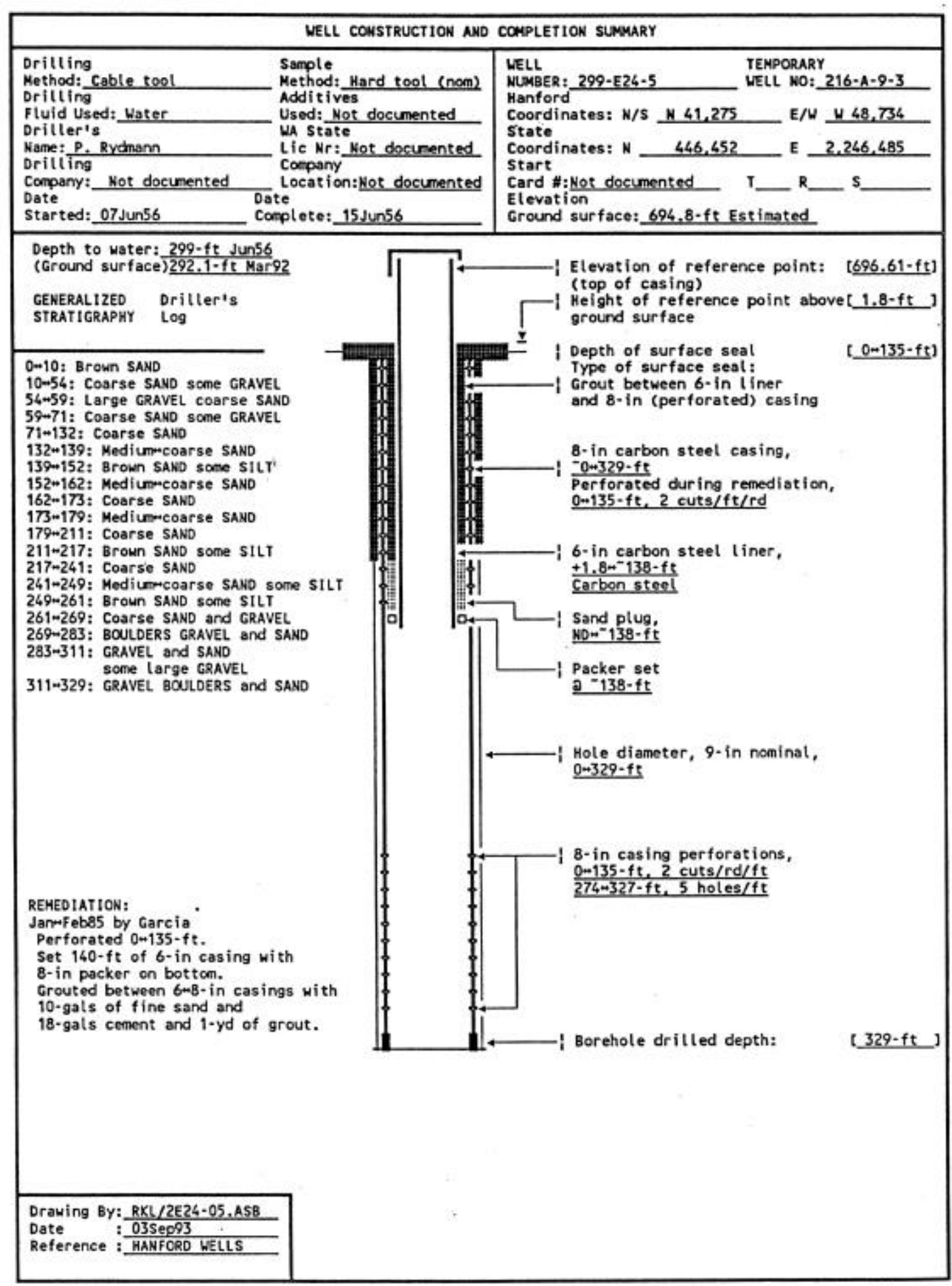




\section{SUMMARY OF CONSTRUCTION DATA AND FIELD OBSERVATIONS RESOURCE PROTECTION WELL - 299-E24-5}

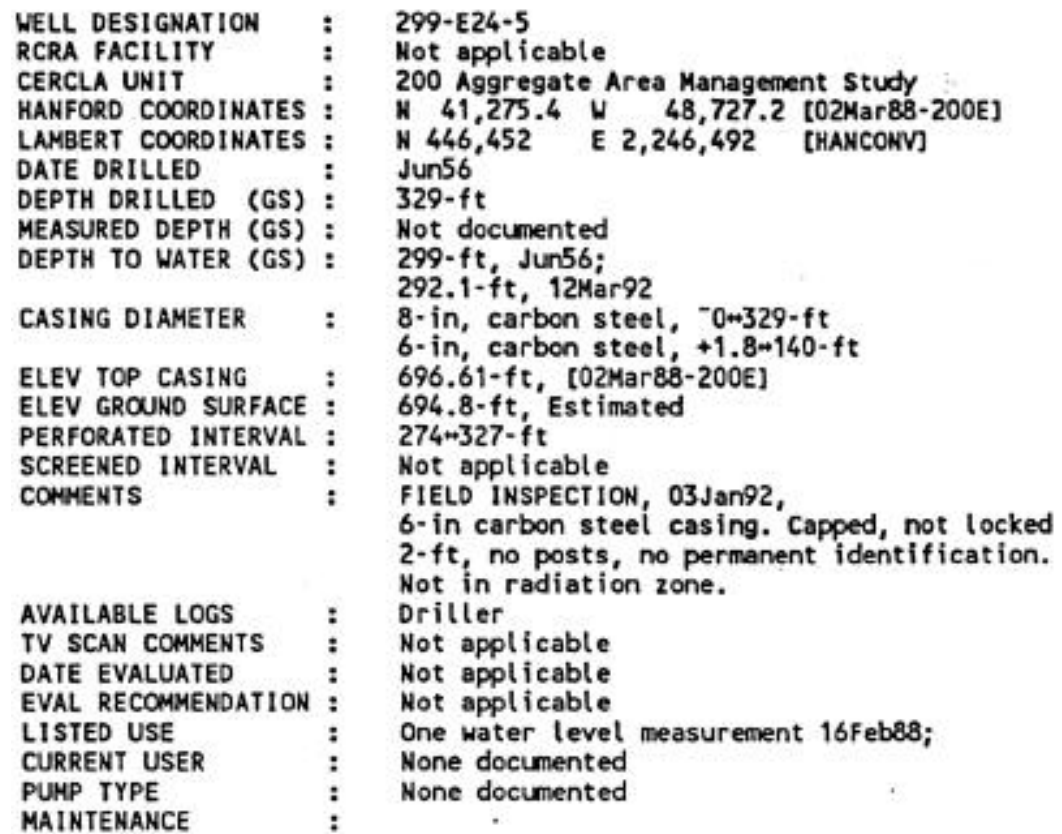




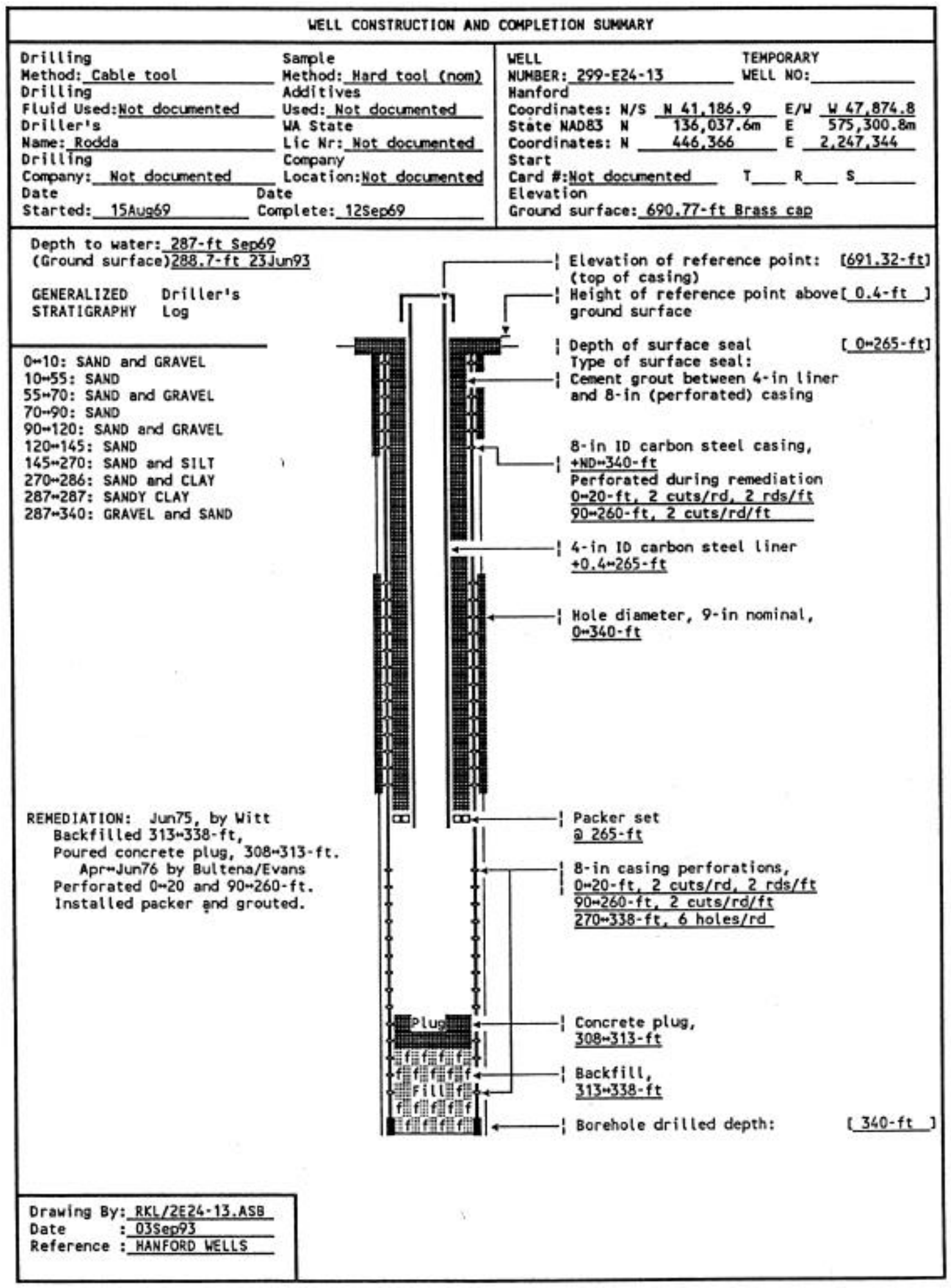




\section{SUMMARY OF CONSTRUCTION DATA AND FIELD OBSERVATIONS RESOURCE PROTECTION WELL - 299-E24-13}

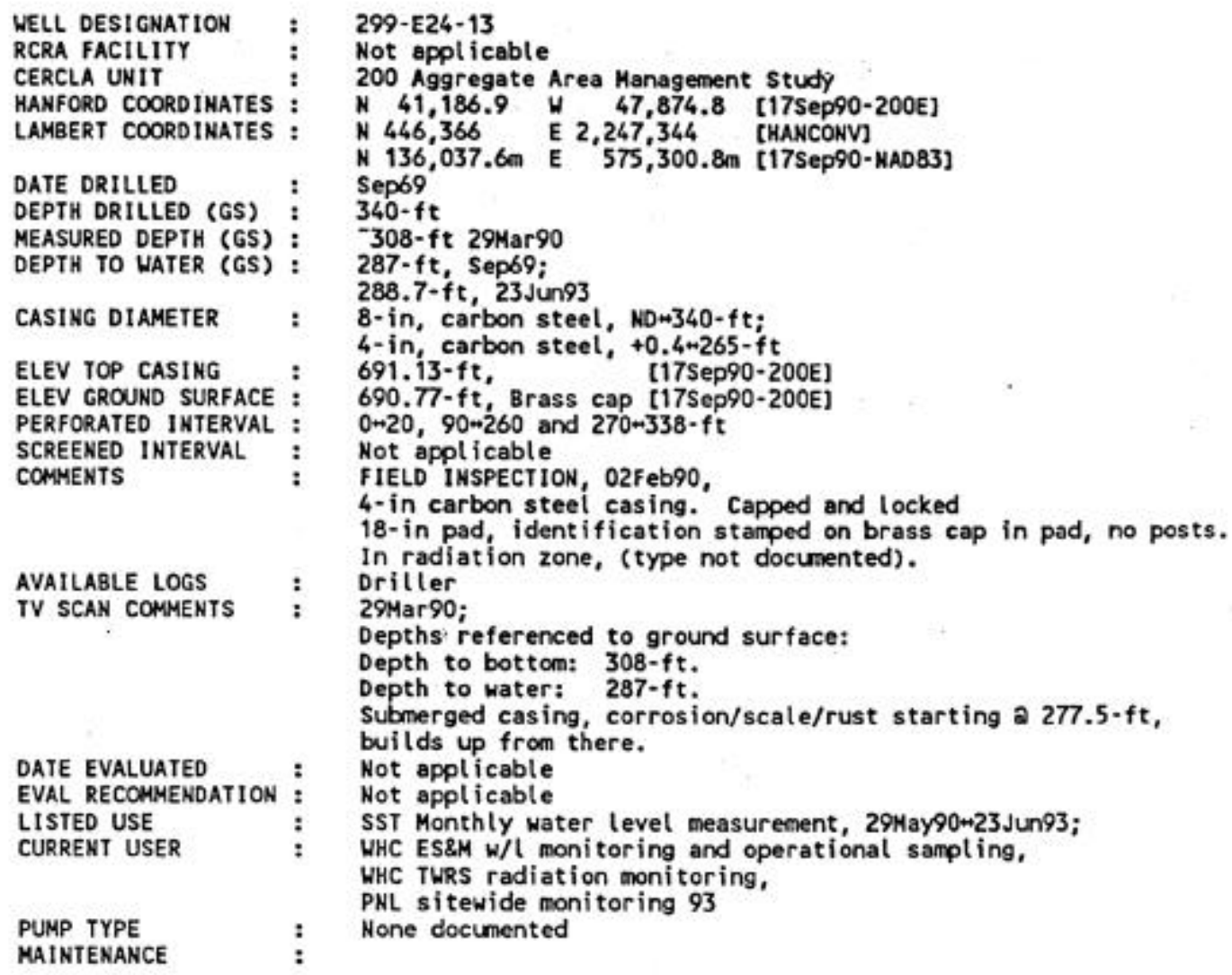




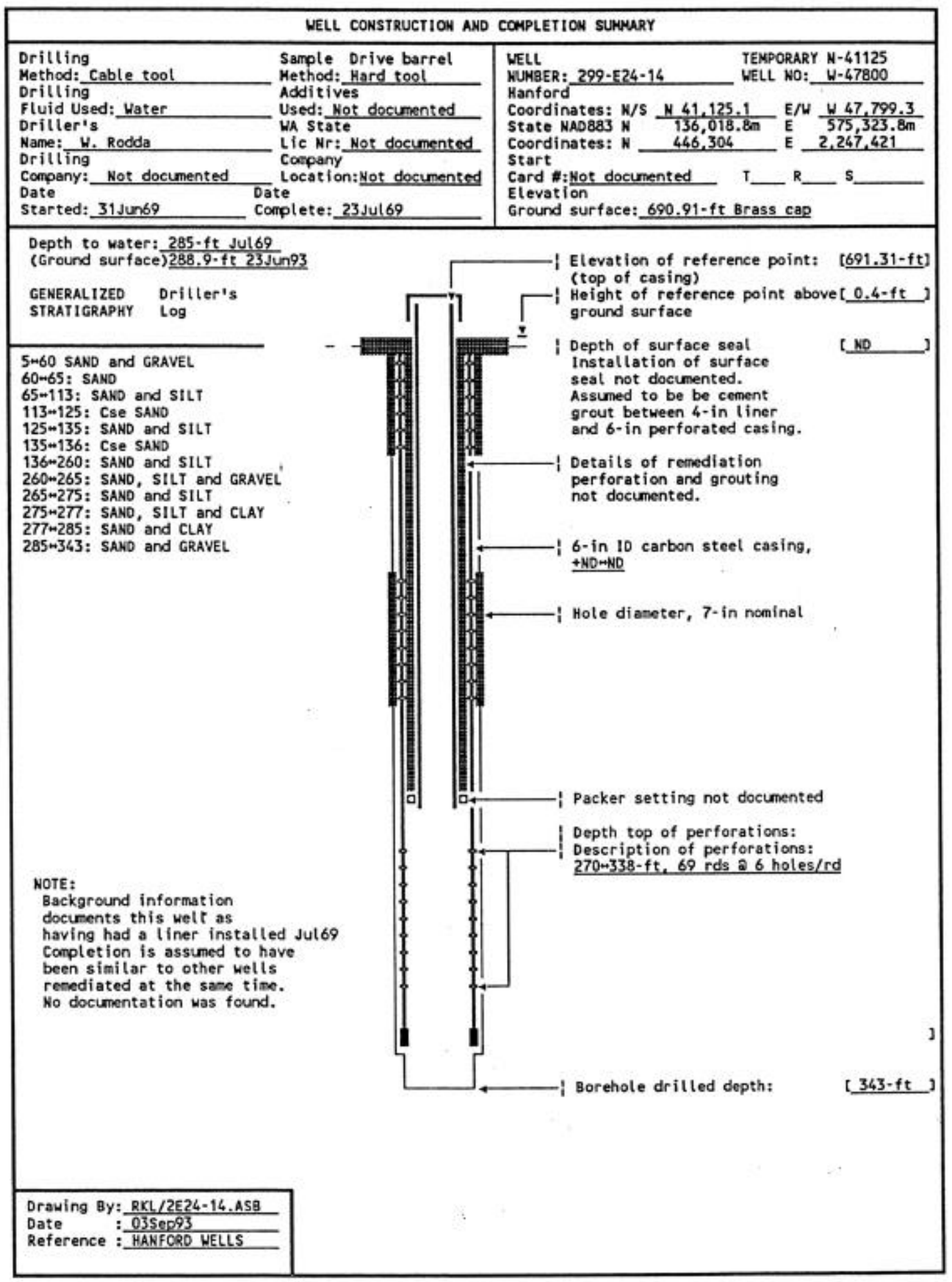




\section{SUMMARY OF CONSTRUCTION DATA AND FIELD OBSERVATIONS RESOURCE PROTECTION WELL - 299-E24-14}






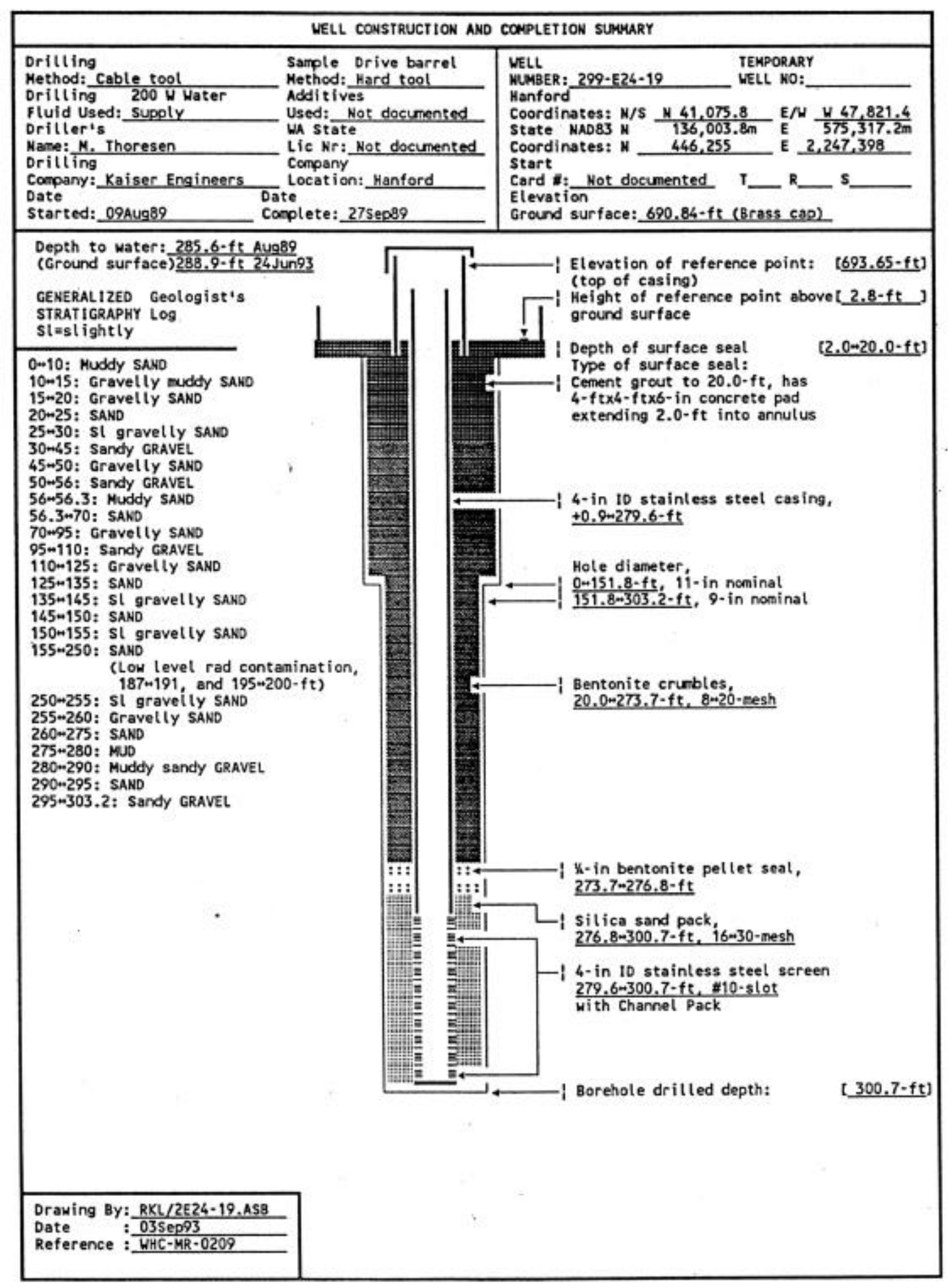




\section{SUMMARY OF CONSTRUCTION DATA AND FIELD OBSERVATIONS RESOURCE PROTECTION WELL - 299-E24-19}

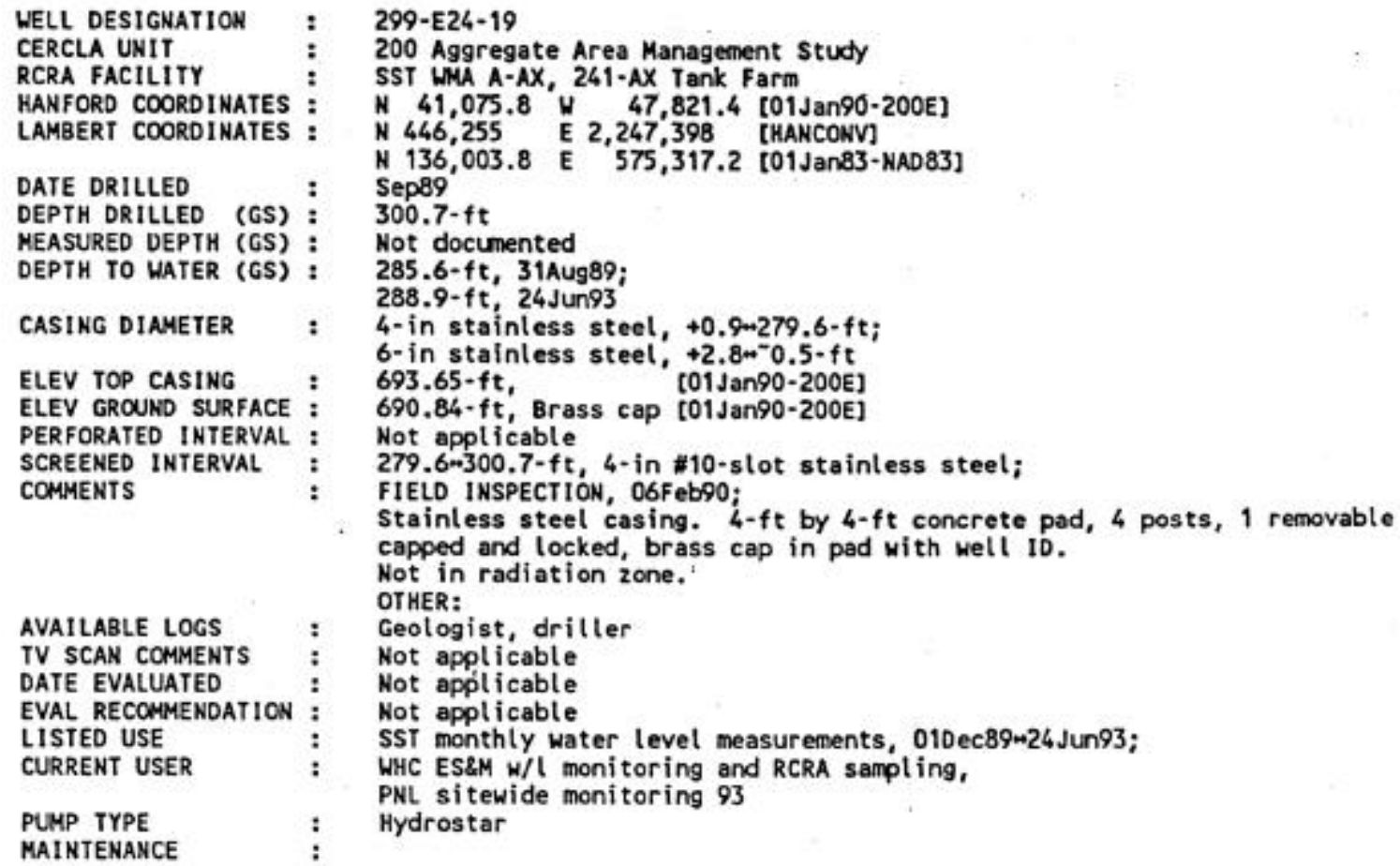

MAINTENAMCE 


\begin{tabular}{|c|c|c|c|}
\hline \multicolumn{4}{|c|}{ WELL CONSTRUCTION AND COMPLETION SUMMARY } \\
\hline $\begin{array}{l}\text { Drilling } \\
\text { Method:-Cable tool } \\
\text { Drilling } \\
\text { Fluid Used:_Row water } \\
\text { Driller's } \\
\text { Name: Kolson } \\
\text { Drilling } \\
\text { Company:_Kaiser Engineers } \\
\text { Date } \\
\text { Started: } 31 \text { Jang1 }\end{array}$ & $\begin{array}{l}\text { Sample Orive bart } \\
\text { Method: Hard tool } \\
\text { Additives } \\
\text { Used: None } \\
\text { WA State } \\
\text { Lic Hr: Not docum } \\
\text { Company } \\
\text { Location: Hanford } \\
\text { te } \\
\text { oplete: } 14 \text { Mar91 }\end{array}$ & ret &  \\
\hline 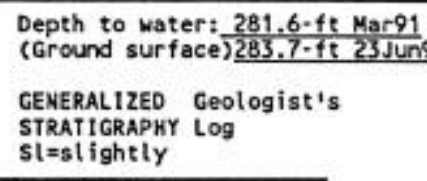 & 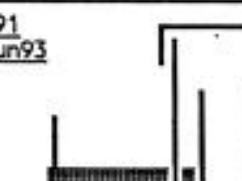 & 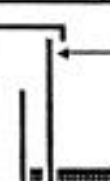 & $\begin{array}{l}\text { - Elevation of reference point: }[689.28-\mathrm{ft}] \\
\text { (top of casing) } \\
\text { 1 Height of reference point abovet } 3.43-\mathrm{ft}] \\
\text { ground surface }\end{array}$ \\
\hline  & 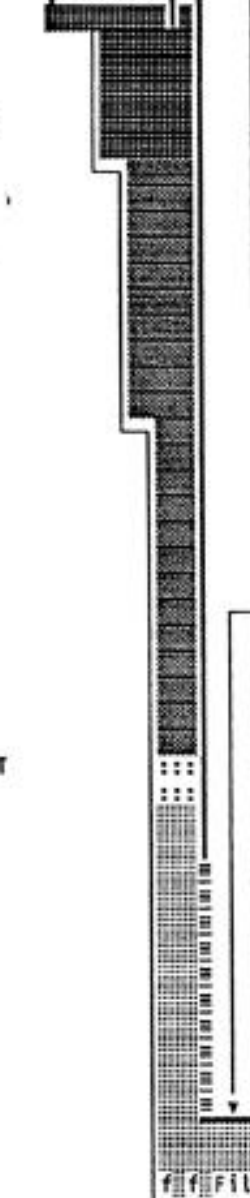 & 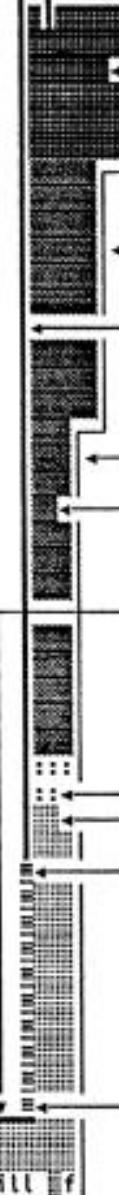 &  \\
\hline . & & & \\
\hline $\begin{array}{l}\text { Drawing By: } \frac{\text { RKL/2E24-20.ASB }}{0 .} \\
\text { Date } \\
\text { Reference }\end{array}$ & & & \\
\hline
\end{tabular}




\section{SUMMARY OF CONSTRUCTION DATA AND FIELD OBSERVATIONS RESOURCE PROTECTION WELL - 299-E24-20}

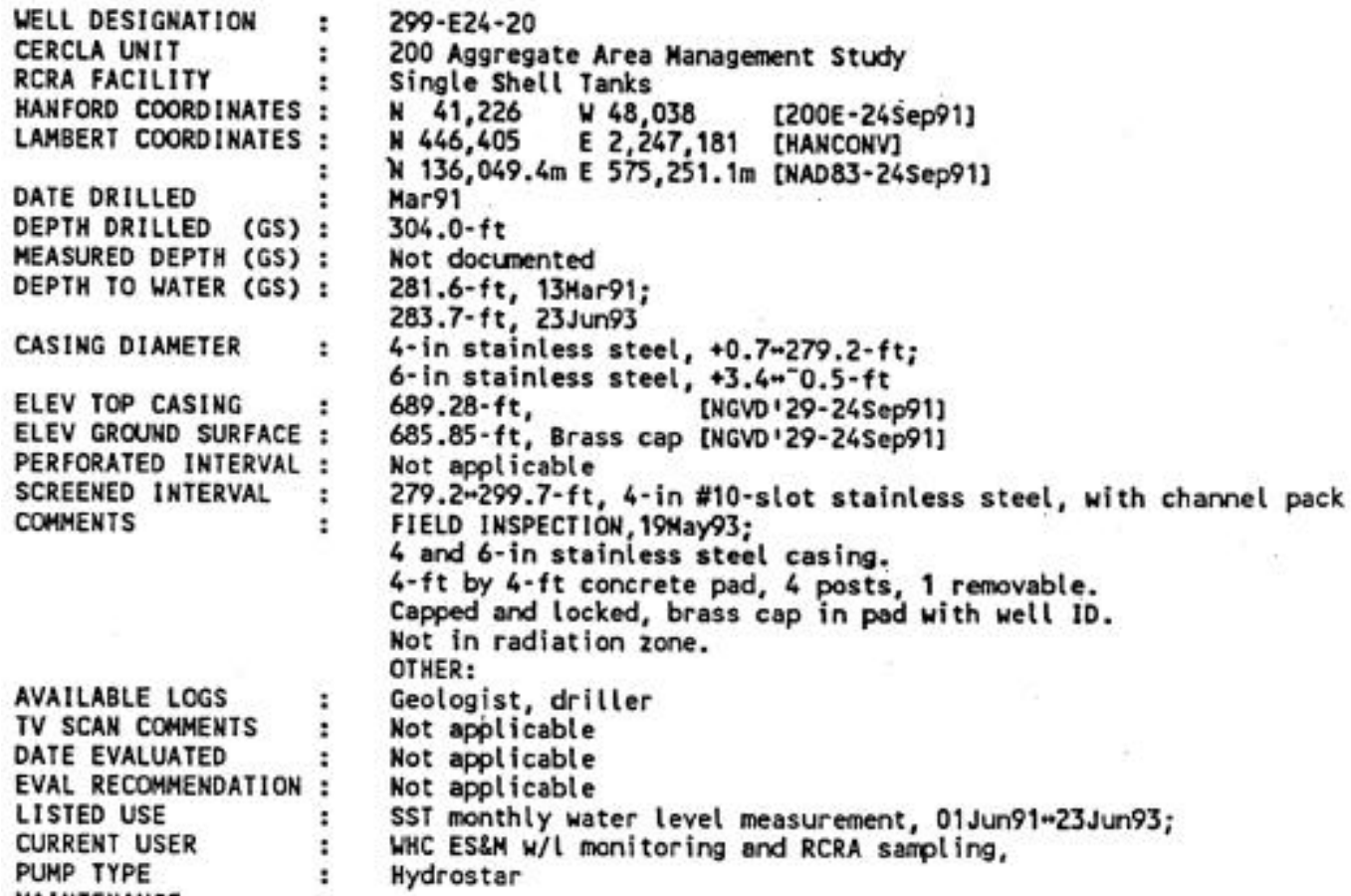




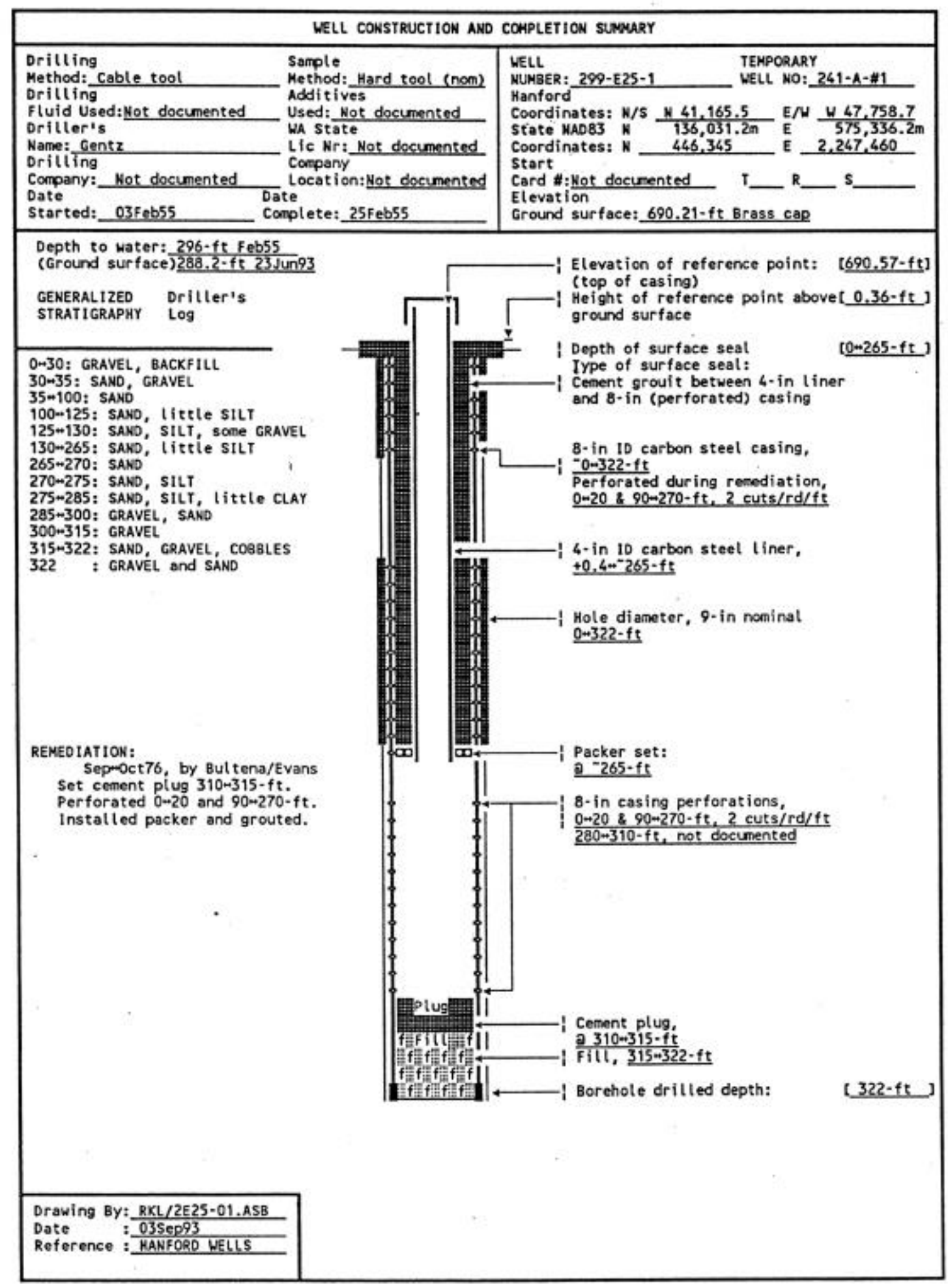




\section{SUMMARY OF CONSTRUCTION DATA AND FIELD OBSERVATIONS RESOURCE PROTECTION WELL - 299-E25-1}

\begin{tabular}{l} 
WELL DESIGNATION \\
RCRA FACILITY \\
CERCLA UNIT \\
HANFORD COORDIHATES : \\
LAMBERT COORDIMATES : \\
DATE DRILLED \\
DEPTH DRILL (GS) \\
MEAS DEPTH (GS) \\
DEPTH WATER (GS) \\
CASIMG DIAMETER \\
ELEV TOP CASING \\
ELEV GROUND SURFACE : \\
PERFORATED INTERVAL : \\
SCREENED INTERVAL \\
COMMENTS \\
\multicolumn{1}{|}{} \\
PUMP TYPE \\
MAINTENANCE \\
AVAILABLE LOGS \\
TV SCAN COMMENTS \\
DATE EVALUATED \\
EVAL RECOMMENDATION \\
LISTED USE \\
CURRENT USER \\
:
\end{tabular}

299-E25-1

Not applicable

200 Aggregate Area Management Study

N 41,165.5 W 47,758.7 [175ep90-200E]

N 446,345 E 2,247, 460 [HANCONV];

N $136,031.2 \mathrm{~m}$ E $547,336.2 \mathrm{~m}$ [17sep90-NAD83]

Feb55

322- $\mathrm{ft}$

Not documented

296-ft, Feb55;

288.2- $\mathrm{ft}, 23$ Jun 93

8-in, carbon steel, 0-322-ft;

4-in, carbon steel, $+0.36=235$ or $-265-\mathrm{ft}$

690.57-ft, [17Sep90-200E]

$690.21-\mathrm{ft}$, Brass cap [17Sep90-200E]

$0-20,90+270$ and $280+310-\mathrm{ft}$

Not applicable

FIELD INSPECTION, O2Feb90,

$4-$ in carbon steel casing. Capped and locked

18-in pad with identifcation stamed on brass marker in pad, no posts.

In surface radiation zone.

Cement plug 310 $315-\mathrm{ft}$

Driller

$14 \mathrm{Feb} 90$ - 4 -in liner in good condition with some cement on surface. Casing below water has heavy scale.

Not applicable

Not appl icable

SST monthly water level measurement, 12Jul74*23Jun93;

WHC ES\&M W/l monitoring,

UHC TURS radiation monitoring

MAINTENANCE

None documented 


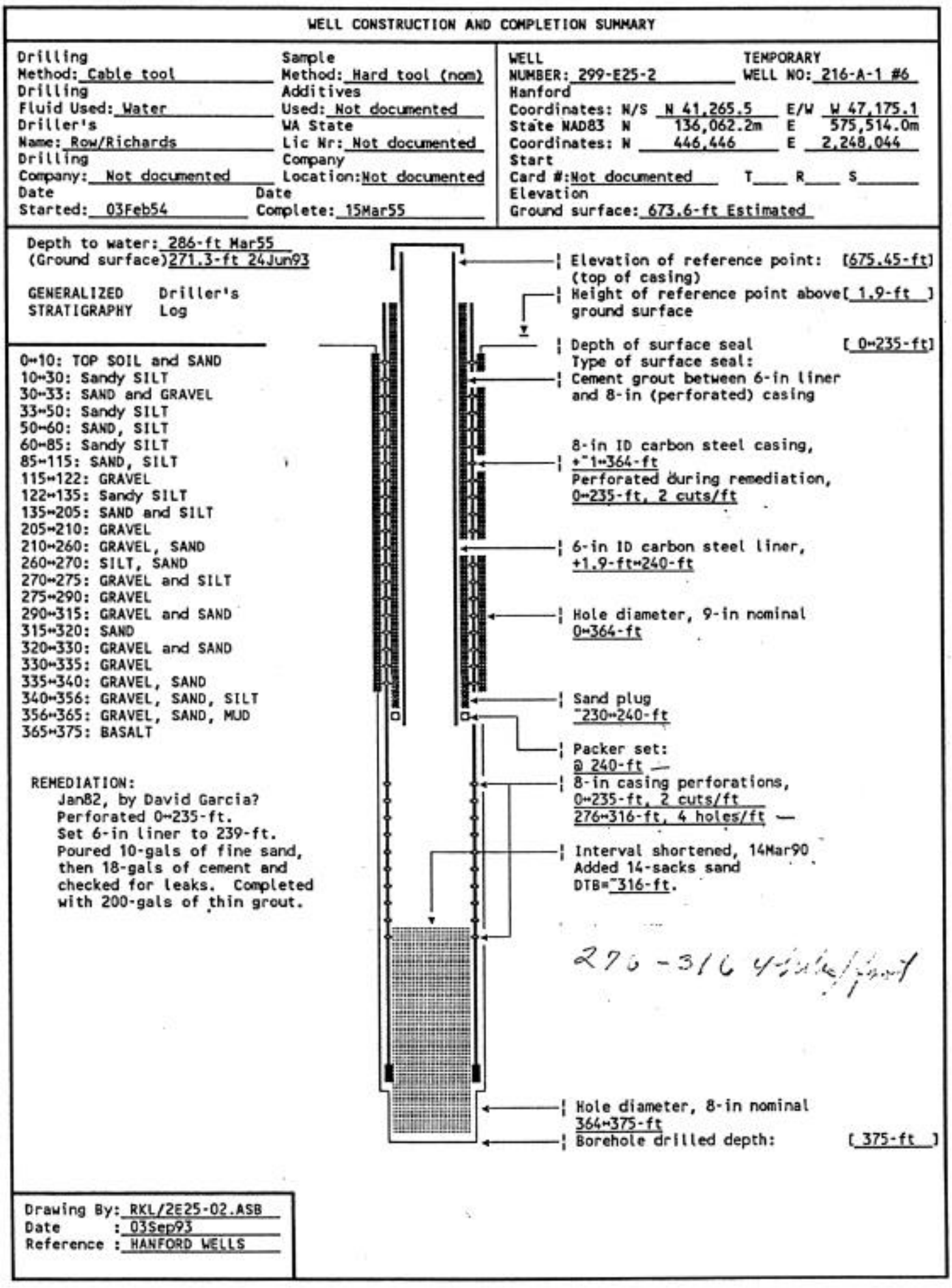




\section{SUMMARY OF CONSTRUCTION DATA AND FIELD OBSERVATIONS RESOURCE PROTECTION WELL - 299-E25-2}

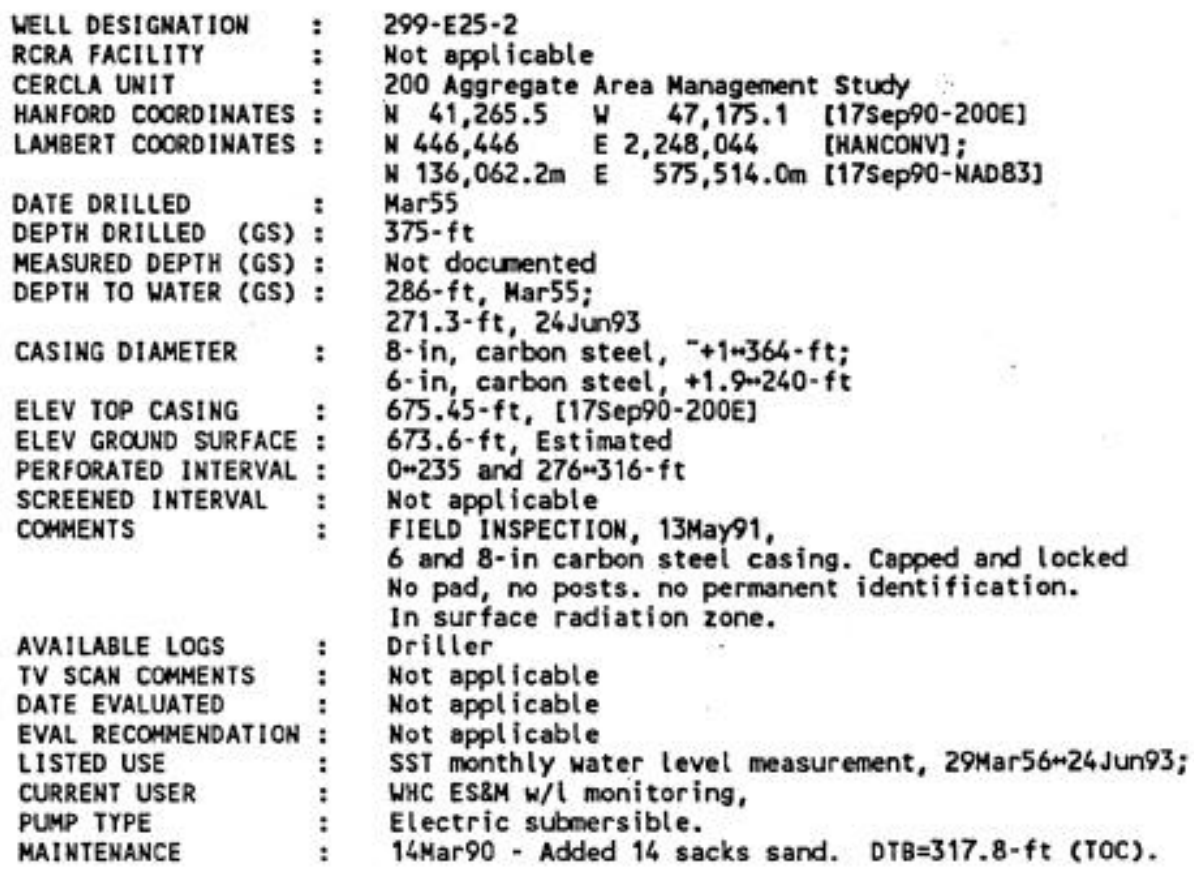




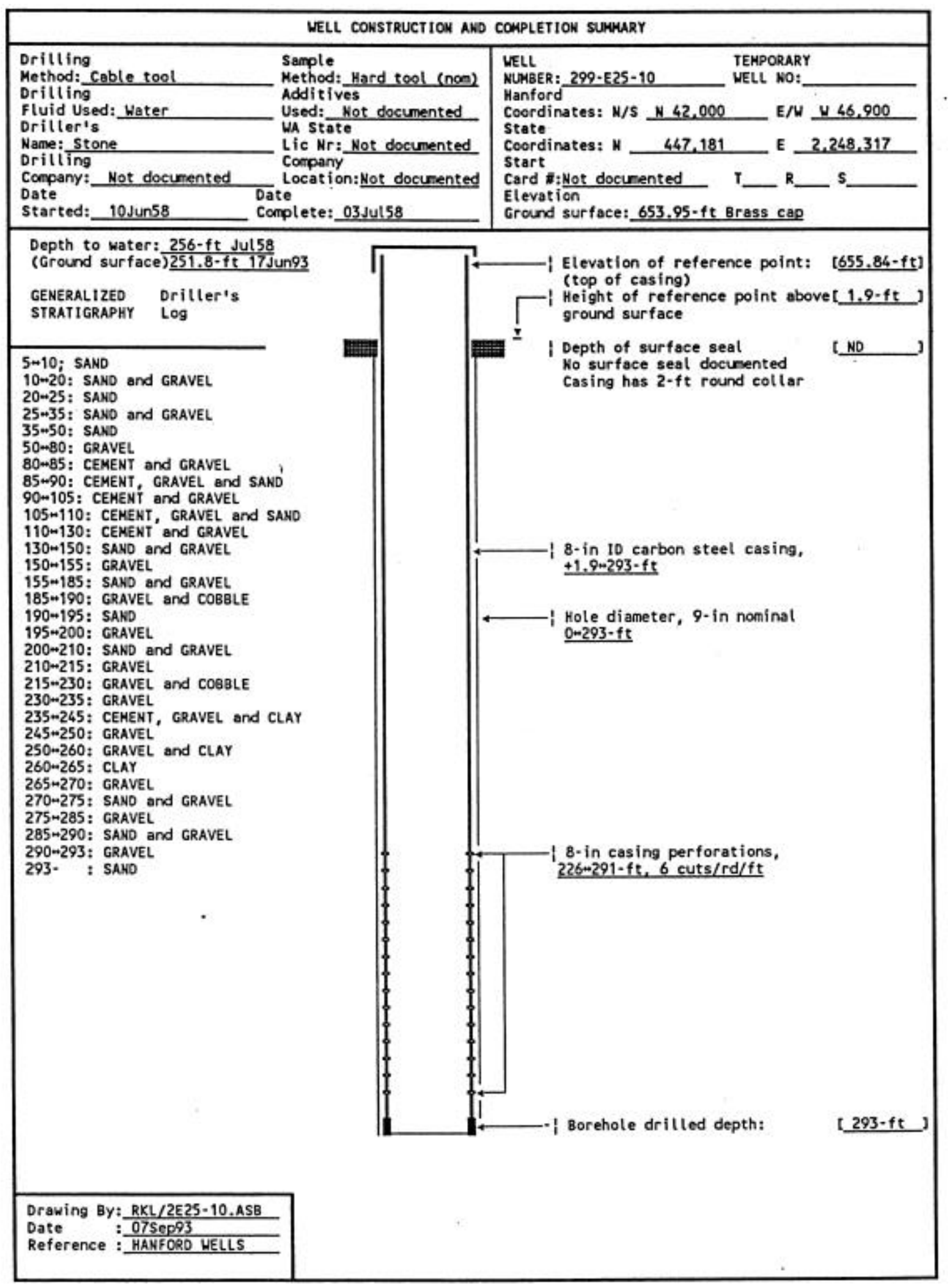




\section{SUMMARY OF CONSTRUCTION DATA AND FIELD OBSERVATIONS \\ RESOURCE PROTECTION WELL - 299-E25-10}

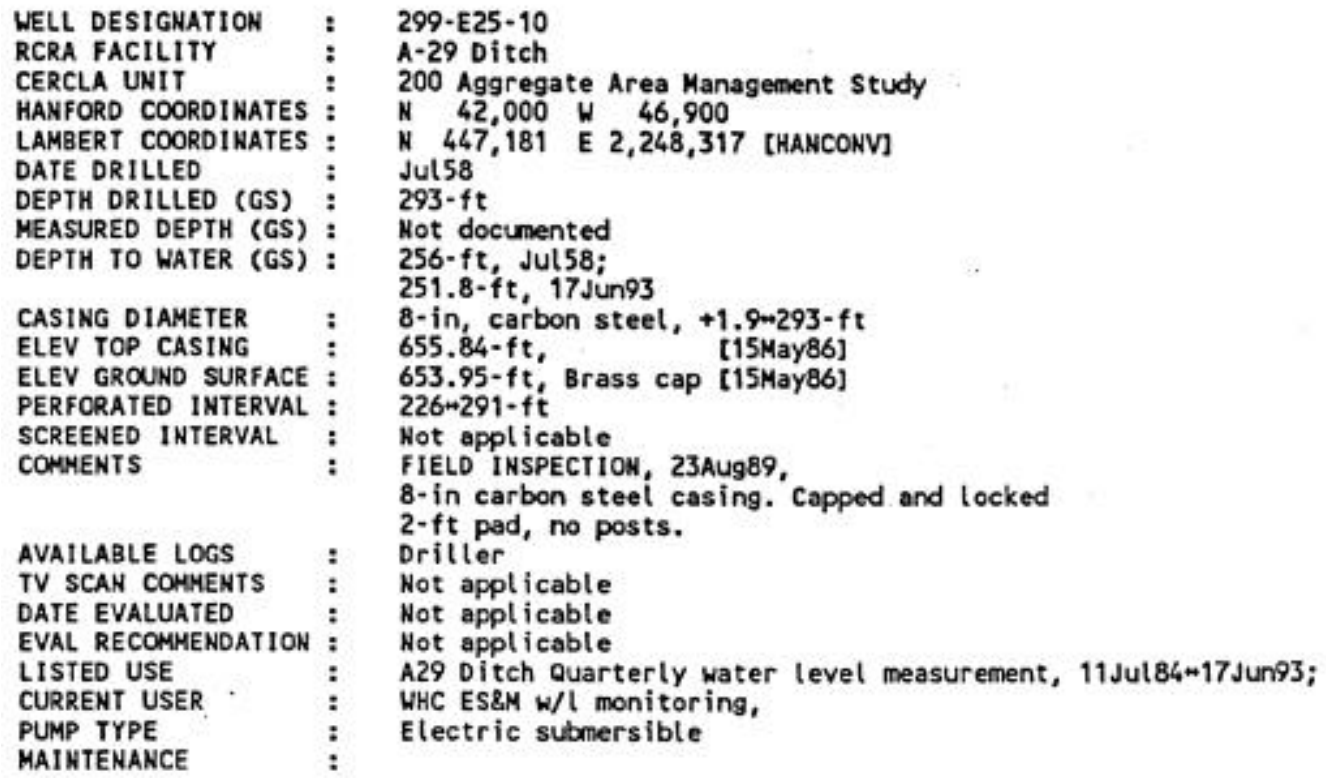




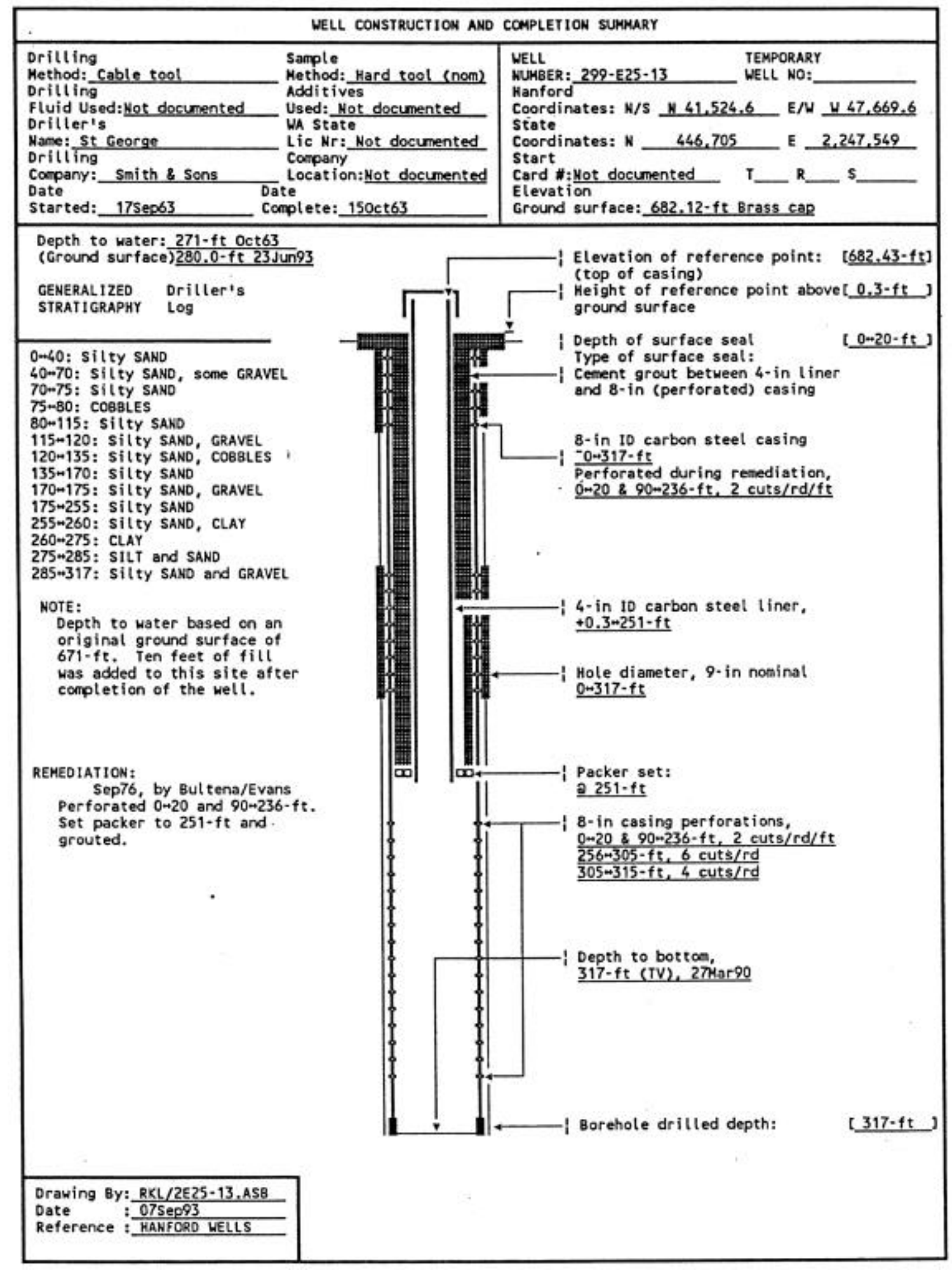




\section{SUMMARY OF CONSTRUCTION DATA AND FIELD OBSERVATIONS RESOURCE PROTECTION WELL - 299-E25-13}

WELL DESIGHATION
RCRA FACILITY
CERCLA UNIT
HANFORD COORDINATES
LAMBERT COORDINATES :
DATE DRILLLD
DEPTH DRILLED (GS)
MEASURED DEPTH (GS)
DEPTH TO WATER (GS)
CASING DIAMETER
ELEV TOP CASING
ELEV GROUND SURFACE
PERFORATED INTERVAL
SCREENED INTERVAL
COMMENTS
A
AVAILABLE LOGS
TV SCAN COHMENTS
PUMP TYPE
MAINTENANCE
DATE EVALUATED
EVAL RECOMMENDATION
LISTED USE
CURRENT USER
:

299-E25- 13

SST

200 Aggregate Area Management Study.

N 41,524.6 W 47,669.6 [17Sep90-200E]

N 446,705 E 2,247,549 [HANCONV]

N $136,140.7 \mathrm{~m}$ E $575,363.0 \mathrm{~m}$ [17Sep90-NAD83]

0 ct63

317-ft

Not documented

271-ft, Oct63;

280.0-ft, 23 Jun93

8-in, carbon steel, 0u317-ft;

$4-$ in, carbon steel, $+0.3+198$ or $-251-\mathrm{ft}$

682.43-ft, [17Sep90-200E]

$682.12-\mathrm{ft}$, Brass cap [17Sep90-200E]

$0+20,90-236$ and $256 * 315-\mathrm{ft}$

Not applicable

FIELD IMSPECTION, O2Feb90,

4 -in carbon steel casing. Capped and locked

18-in pad with identification stamped on brass marker in pad. No posts. In surface radiation zone.

Driller

$27 \mathrm{Mar} 90$;

DTW $=277.5-\mathrm{ft}$

DTB=317-ft

Vadose casing has scale starting a $262.4-\mathrm{ft}$.

Perforations start a 209.9-ft.

Hot applicable

Hot applicable

SST Monthly water levels measurement, 22Mar90m23 Jun93;

WHC ES\&H W/I monitoring,

PNL sitewide sampling 93

None documented 


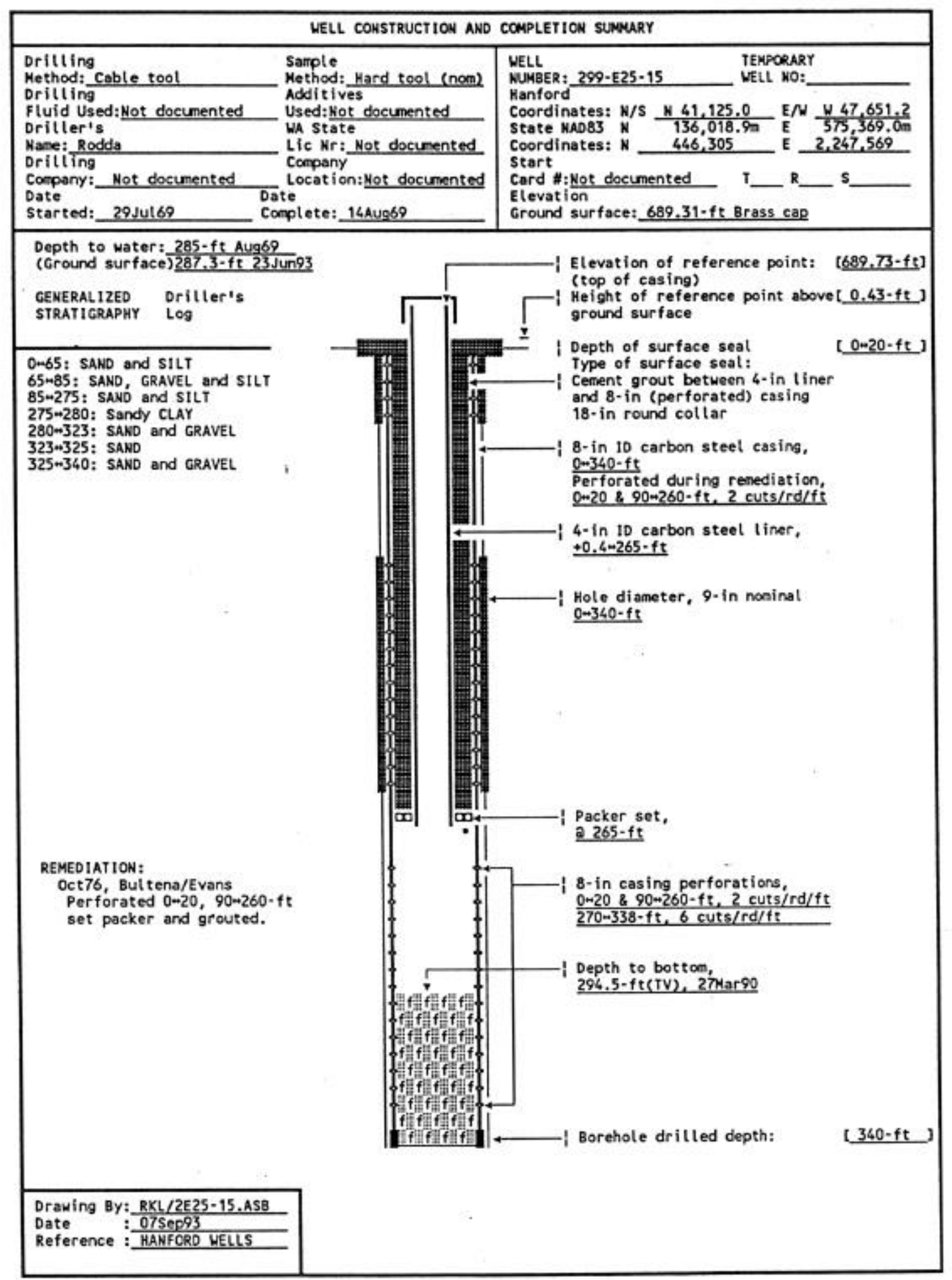




\section{SUMMARY OF CONSTRUCTION DATA AND FIELD OBSERVATIONS RESOURCE PROTECTION WELL - 299-E25-15}

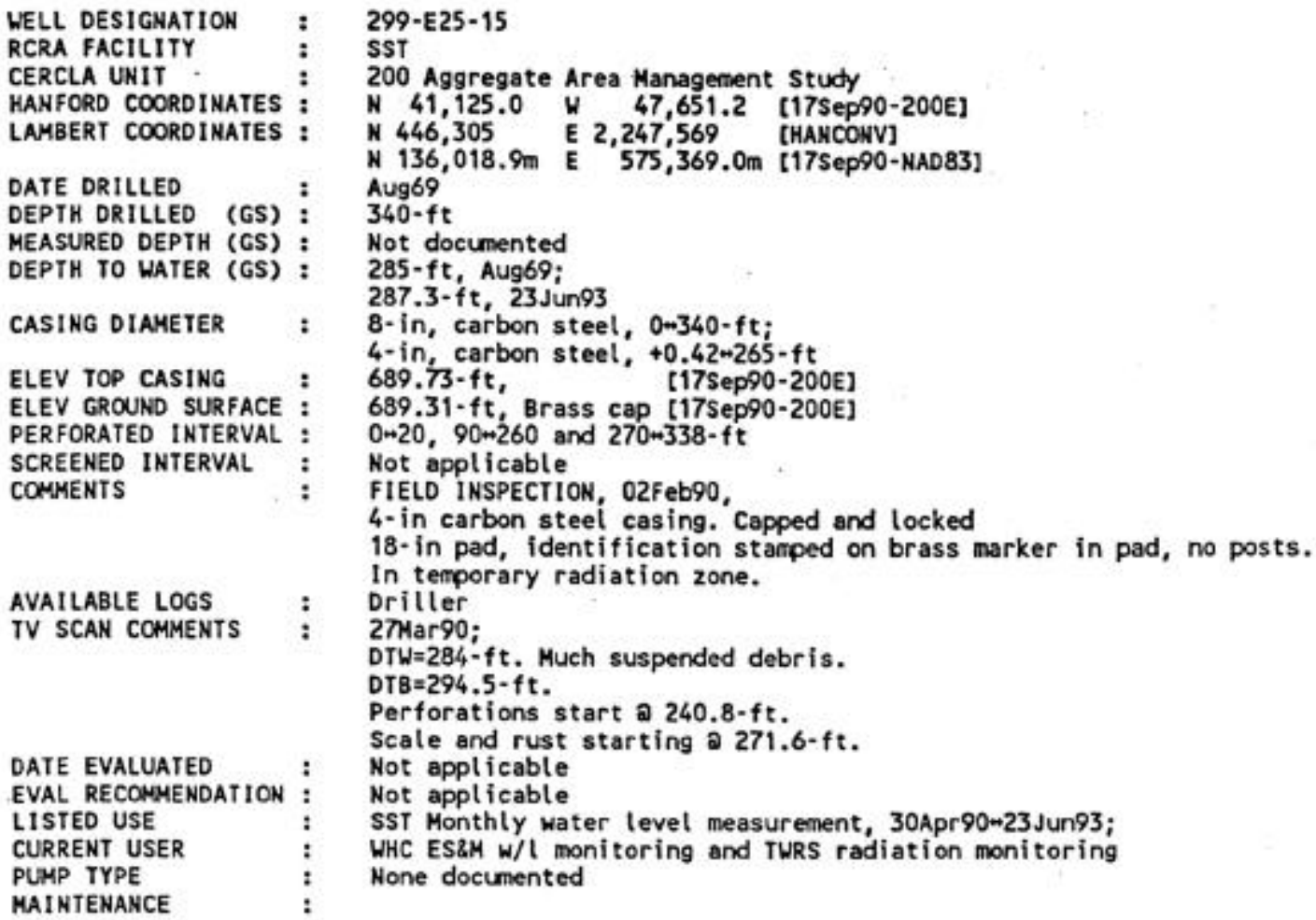




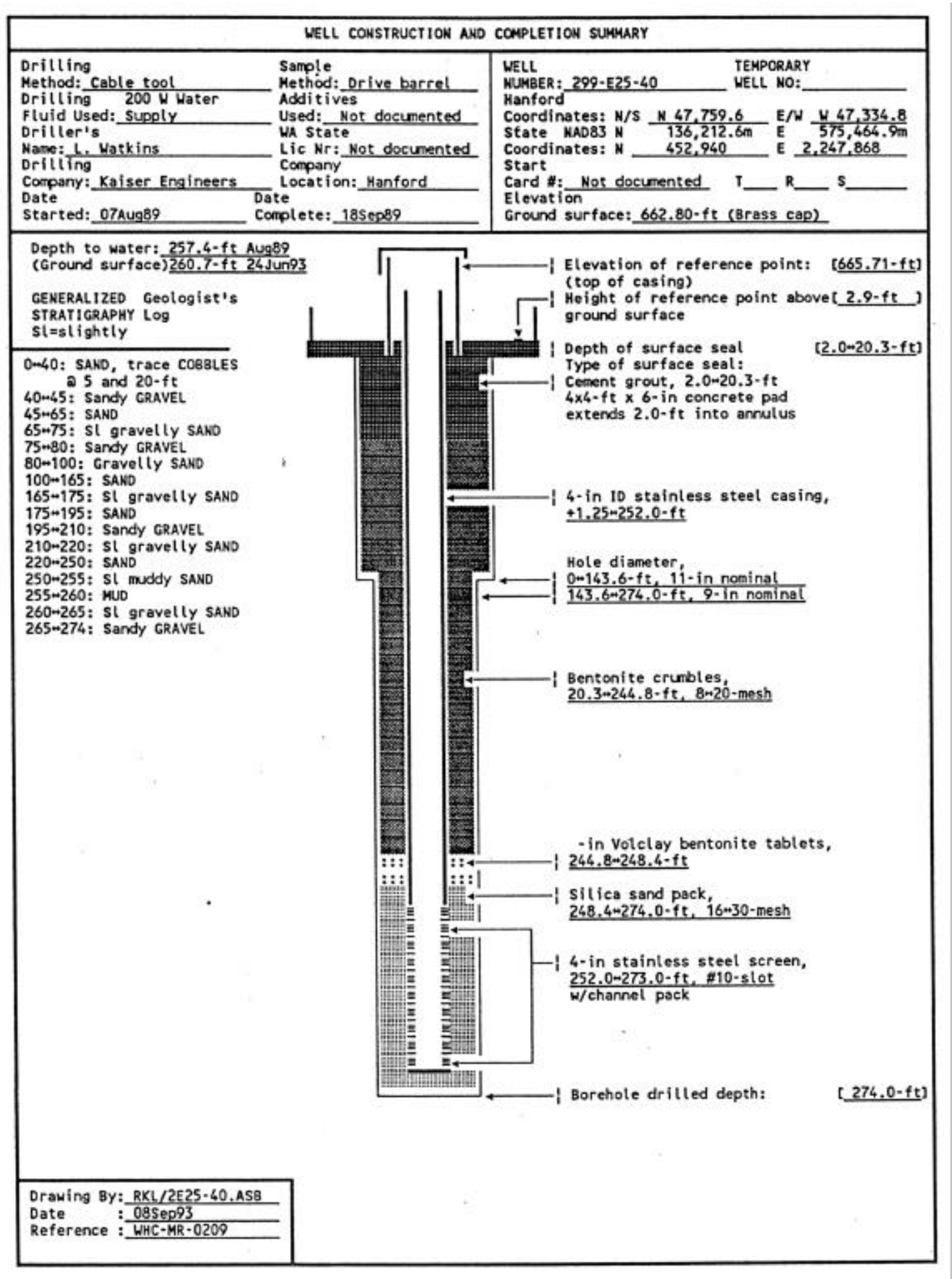




\section{SUMMARY OF CONSTRUCTION DATA AND FIELD OBSERVATIONS RESOURCE PROTECTION WELL - 299-E25-40}

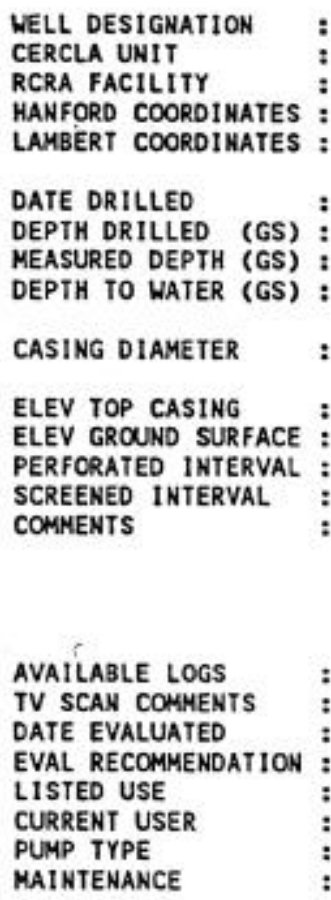

299-E25- 40

200 Aggregate Area Management Study SST INA A-AX, 241-AX Tank Farm

N $47,759.6$ W $47,334.8$ [O J Jañ $90-200 E$ ]

N 452,940 E 2,247,868; [HANCONV]

N 136,212.6m E $575,464.9 \mathrm{~m}$ [04Jan909-NAD83] Sep89

274.0- $\mathrm{ft}$

Not documented

257.4-ft, 31Aug89:

260.7- $\mathrm{ft}, 24$ Jungs

4-in staintess steel, $+1.25+252.0-\mathrm{ft}$;

6 -in stainless steel, $+2.9-0.5-\mathrm{ft}$

665.71- $\mathrm{ft}$, [04 Jan90-200E]

$662.80-\mathrm{ft}$, Brass cap [04Jan90-200E]

Not applicable

$252.0 m 273.0-\mathrm{ft}, 4-$ in $\# 10-$ slot stainless steel w/channel pack FIELD INSPECTION, 02Feb90;

stainless steel casing. $4-\mathrm{ft}$ by $4-\mathrm{ft}$ concrete pad, 4 posts, 1 removable capped and locked, brass cap in pad with well to.

Not in radiation zone.

OTHER:

Geologist, driller

Not applicable

Not app'l icable

Not applicable

SST monthly water level measurement, 010ec89-24Jun93;

WHC ES\&M w/l monitoring and RCRA sampling

Hydrostar 


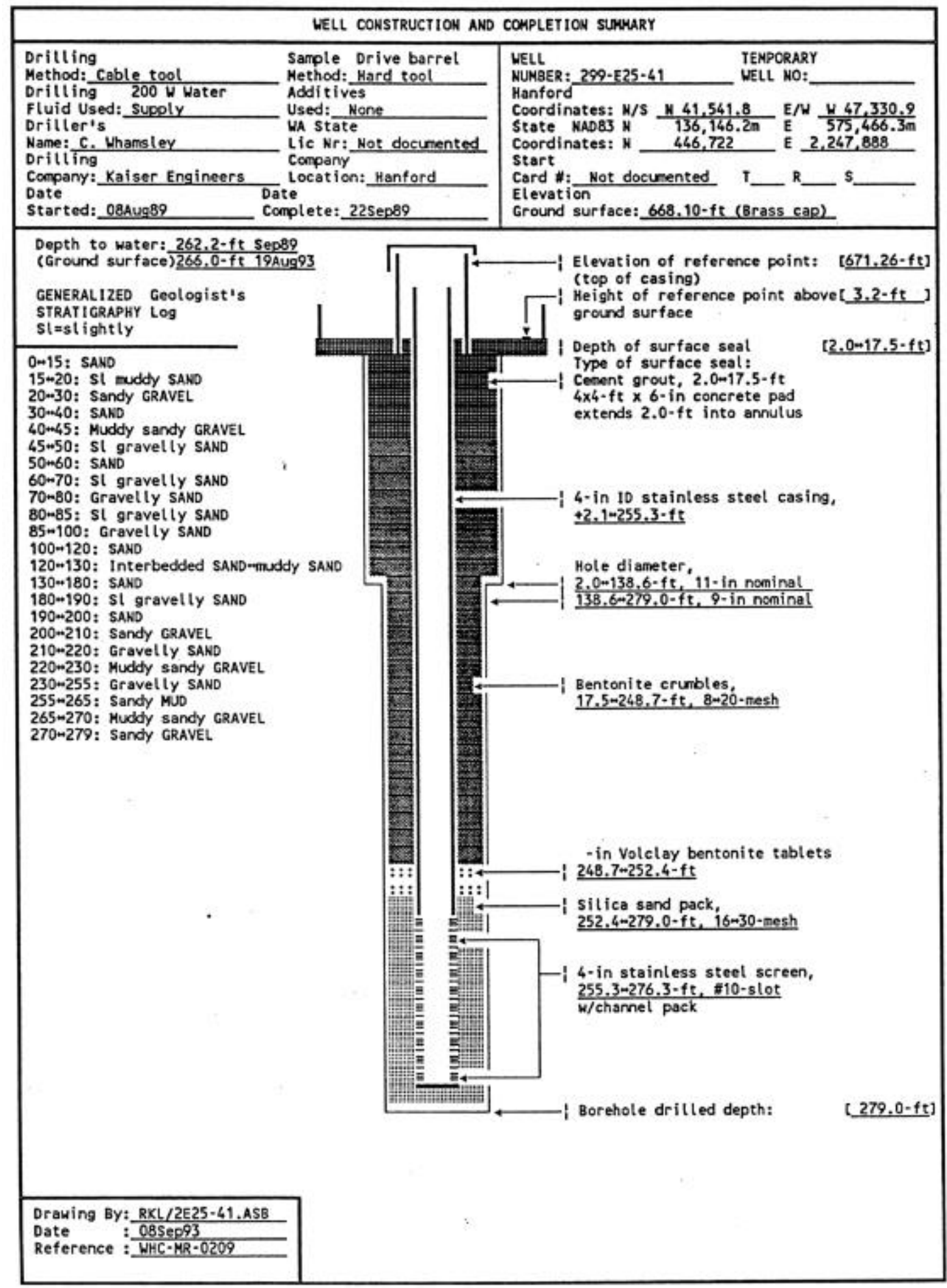




\section{SUMMARY OF CONSTRUCTION DATA AND FIELD OBSERVATIONS RESOURCE PROTECTION WELL - 299-E25-41}

\begin{tabular}{l} 
WELL DESIGNATION \\
CERCLA UNIT \\
RCRA FACILIIY \\
HANFORD COORDINATES \\
LAMBERT COORDINATES : \\
DATE DRILLED \\
DEPTH DRILLED (GS) \\
MEASURED DEPTH (GS) \\
DEPTH TO WATER (GS) \\
CASIMG DIAMETER \\
ELEV TOP CASING \\
ELEV GROUND SURFACE \\
PERFORATED IMTERVAL \\
SCREENED INTERVAL \\
COMMENTS \\
\multicolumn{1}{c}{} \\
AVAILABLE LOGS \\
TV SCAN COMMENTS \\
DATE EVALUATED \\
EVAL RECOHMENDATION \\
LISTED USE \\
CURRENT USER \\
PUMP TYPE \\
MAINTENANCE
\end{tabular}

299-E25-41

200 Aggregate Area Management study

SST WMA A-AX, 241-AX Tank Farm

$N 41,541.8$ W $47,330.9$ [04Jan90-200E]

N 446,722 E 2,247,888 [HANCONV]

$N 136,146.2 \mathrm{~m}$ E $575,466.3 \mathrm{~m}$ [04Jan90-MAD83]

Sep89

$279.0-\mathrm{ft}$

Not documented

262.2-ft, 22Sep89;

266.0-ft, 19Aug93

$4-$ in staintess steel, $+2.1+255.3-\mathrm{ft}$;

$6-$ in stainless steel; $+3.2=0.5-\mathrm{ft}$

671.26- $\mathrm{ft}$

668.10-ft (Brass cap)

Not appl icable

$255.3+276.3-\mathrm{ft}, 4$-in $\# 10-\mathrm{sl}$ ot stainless steel w/channel pack

FIELD INSPECTION, 02F eb90;

stainless steel casing. $4-\mathrm{ft}$ by $4-\mathrm{ft}$ concrete pad, 4 posts, 1 removable capped and locked, brass cap in pad with well to.

Not in radiation zone.

OTHER :

Geologist, driller

Not applicable

Not applicable

Not apol icable

SST monthly water level measurement, 01Dec89m19Aug93;

WHC ES\&N w/l monitoring and RCRA sampling

Hydrostar 


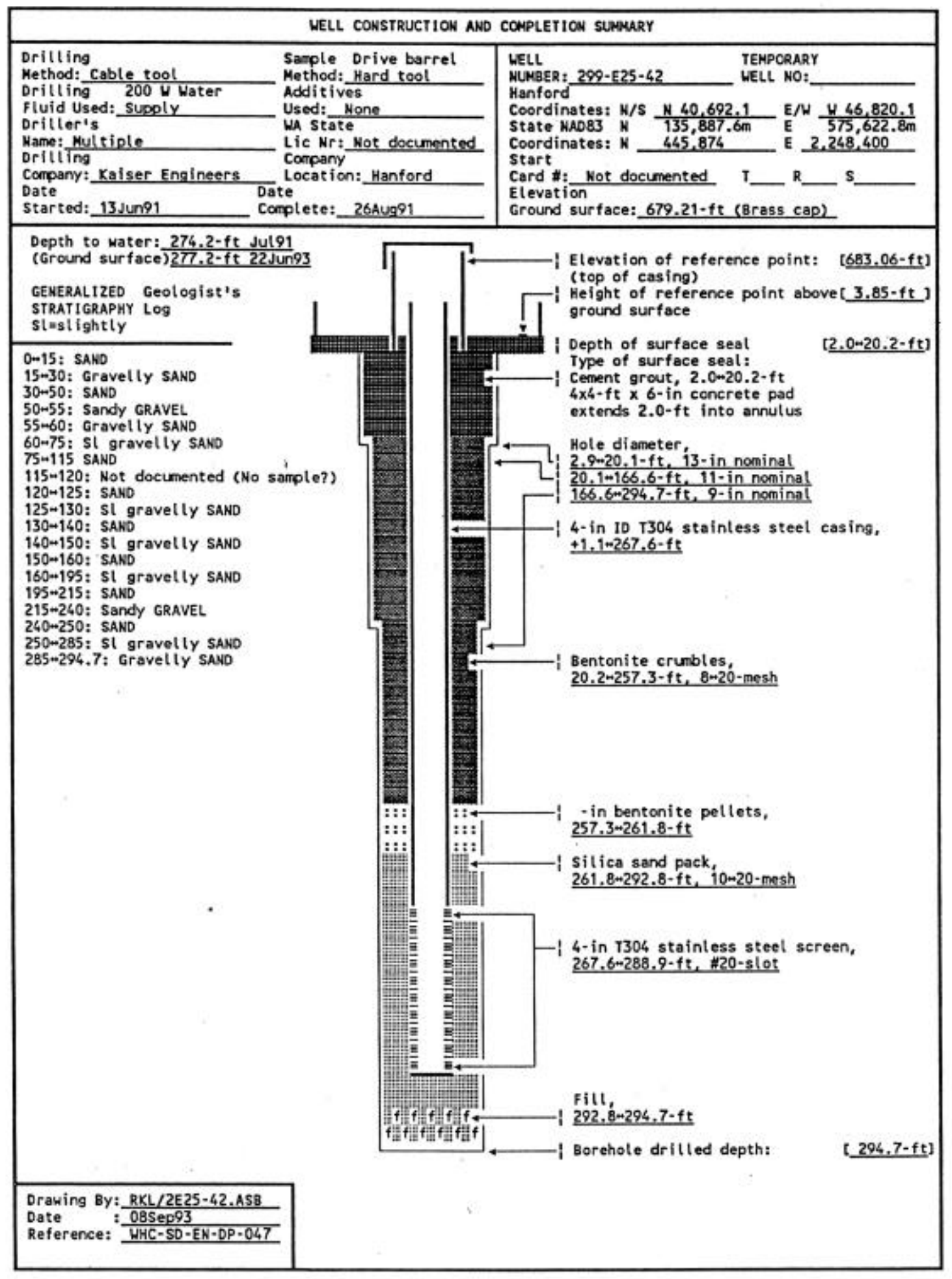




\section{SUMMARY OF CONSTRUCTION DATA AND FIELD OBSERVATIONS \\ RESOURCE PROTECTION WELL - 299-E25-42}

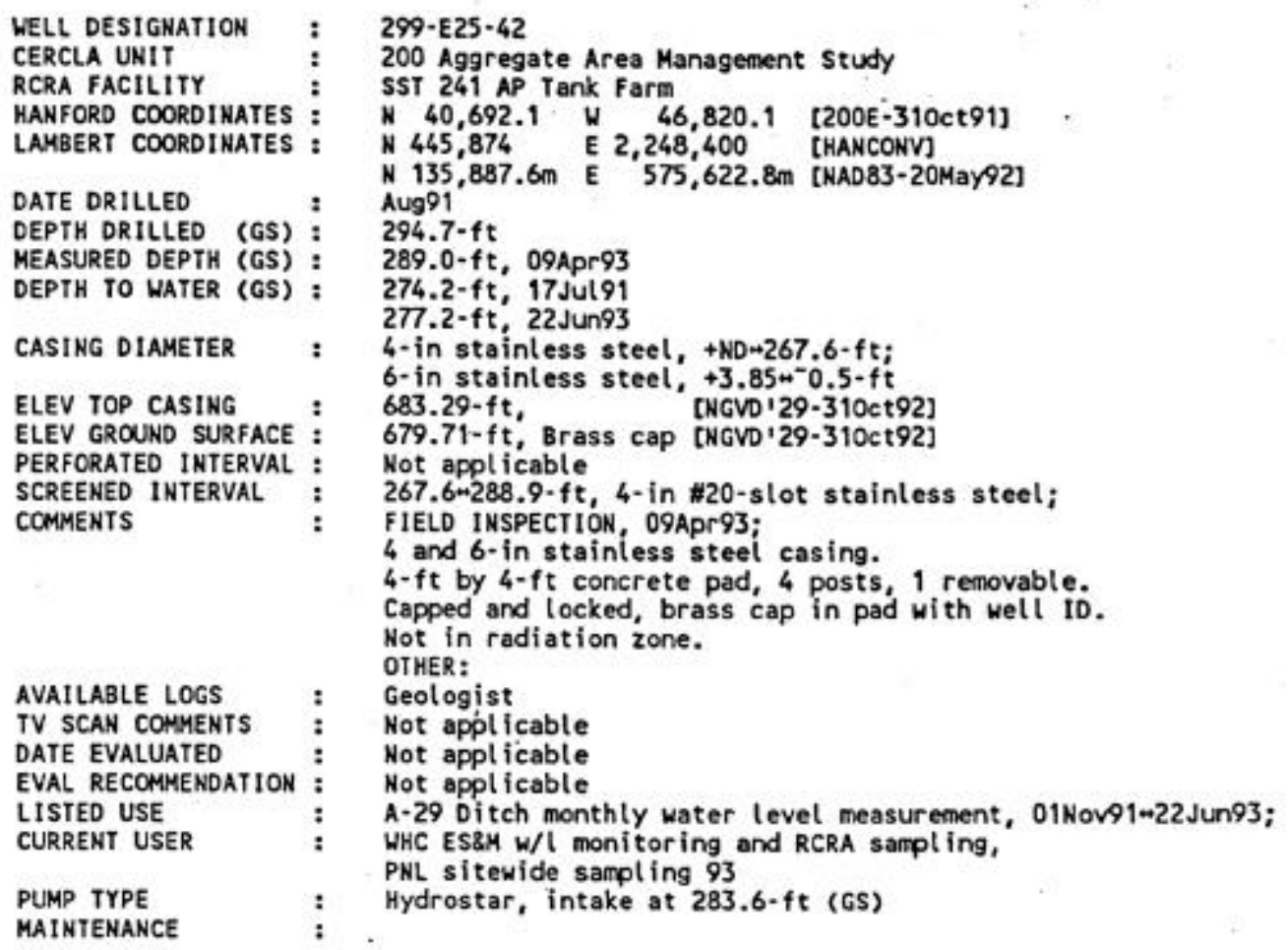




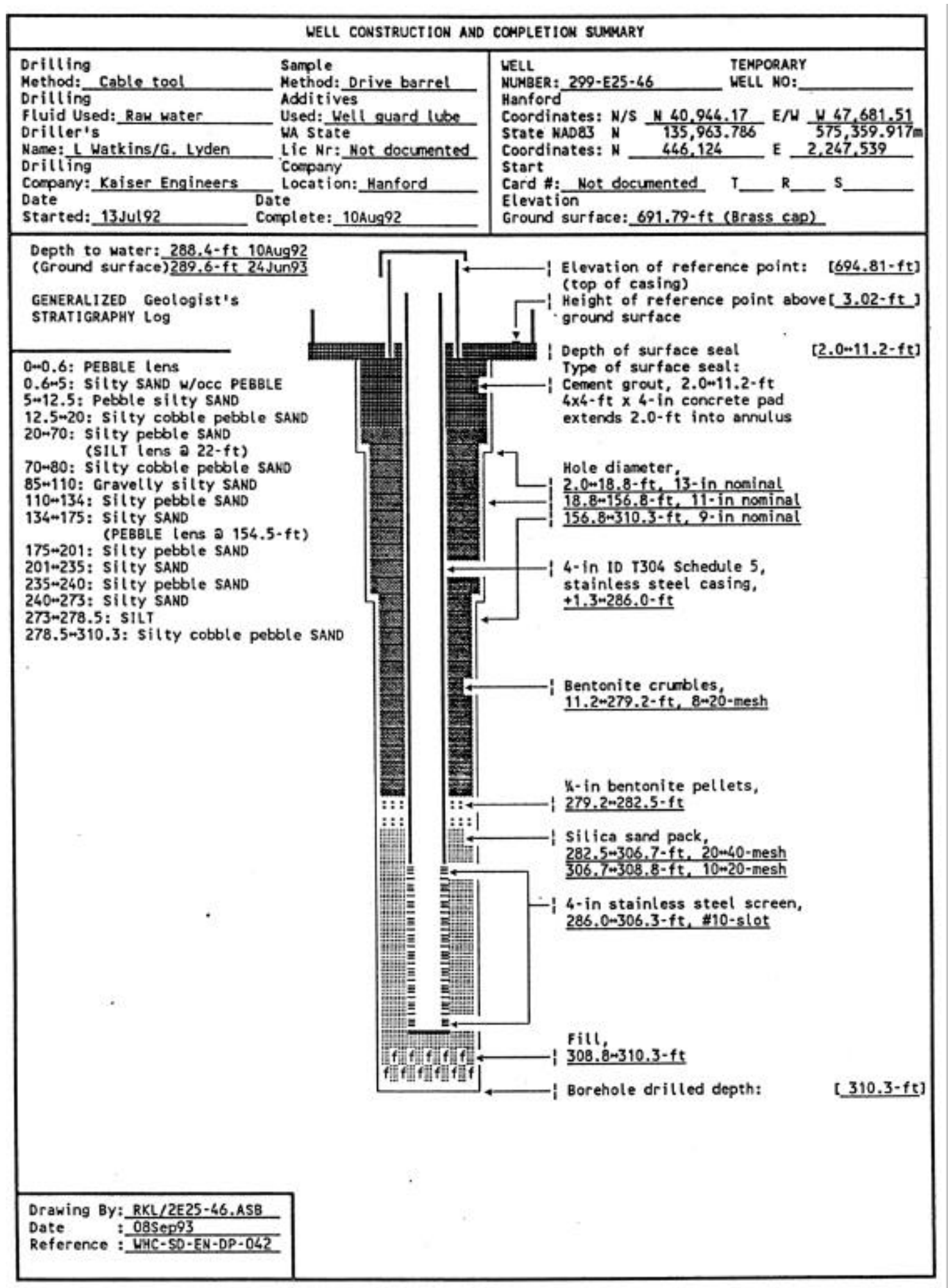




\section{SUMMARY OF CONSTRUCTION DATA AND FIELD OBSERVATIONS RESOURCE PROTECTION WELL - 299-E25-46}

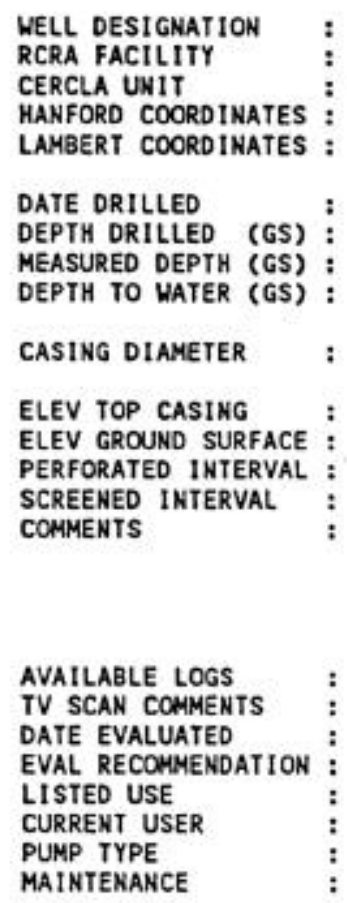

299-E25-46

A29 Evaporator

Not applicable

N 40,944.17

N 446,124

W 47,681.51 [21Sep92-200E]

H 446,124 E 2,247,539

[HANCONV]

N $135,659.15 \mathrm{~m}$ E $576,185.55 \mathrm{~m}$ [NAD83-21'sep92]

Aug92

$310.3-\mathrm{ft}$

306.6- $\mathrm{ft}, 19 \mathrm{May} 93$

$288.4-\mathrm{ft}, 10 \mathrm{Aug} 92$

289.6- $\mathrm{ft}, 24 \mathrm{Jun} 93$

$6-\mathrm{in}$, stainless steel, $+3.0+0.5-\mathrm{ft}$;

4 -in, stainless steel, $+1,3+286,0-\mathrm{ft}$

694.81-ft, [21Sep92-NGVD'29]

691.79-ft, Brass cap [21Sep92-NGVD'29]

Not applicable

286.0-306.3-ft, 4-in stainless steel, \#10-slot

FIELD INSPECTION, 19May93;

4 and 6 -in stainless steel casing.

$4-\mathrm{ft}$ by $4-\mathrm{ft}$ conerete pad, 4 posts, 1 renovable.

Capped and locked, brass cap in pad with well 10.

Not in radiation zone.

Geologist

Not apolicable

Not applicable

Not applicable

SST monthly water level measurement, 200ct92m24 Jun93;

WHC ES\&N W/l monitoring and RCRA sampling

Hydrostar, intake a 289.1-ft (GS) 


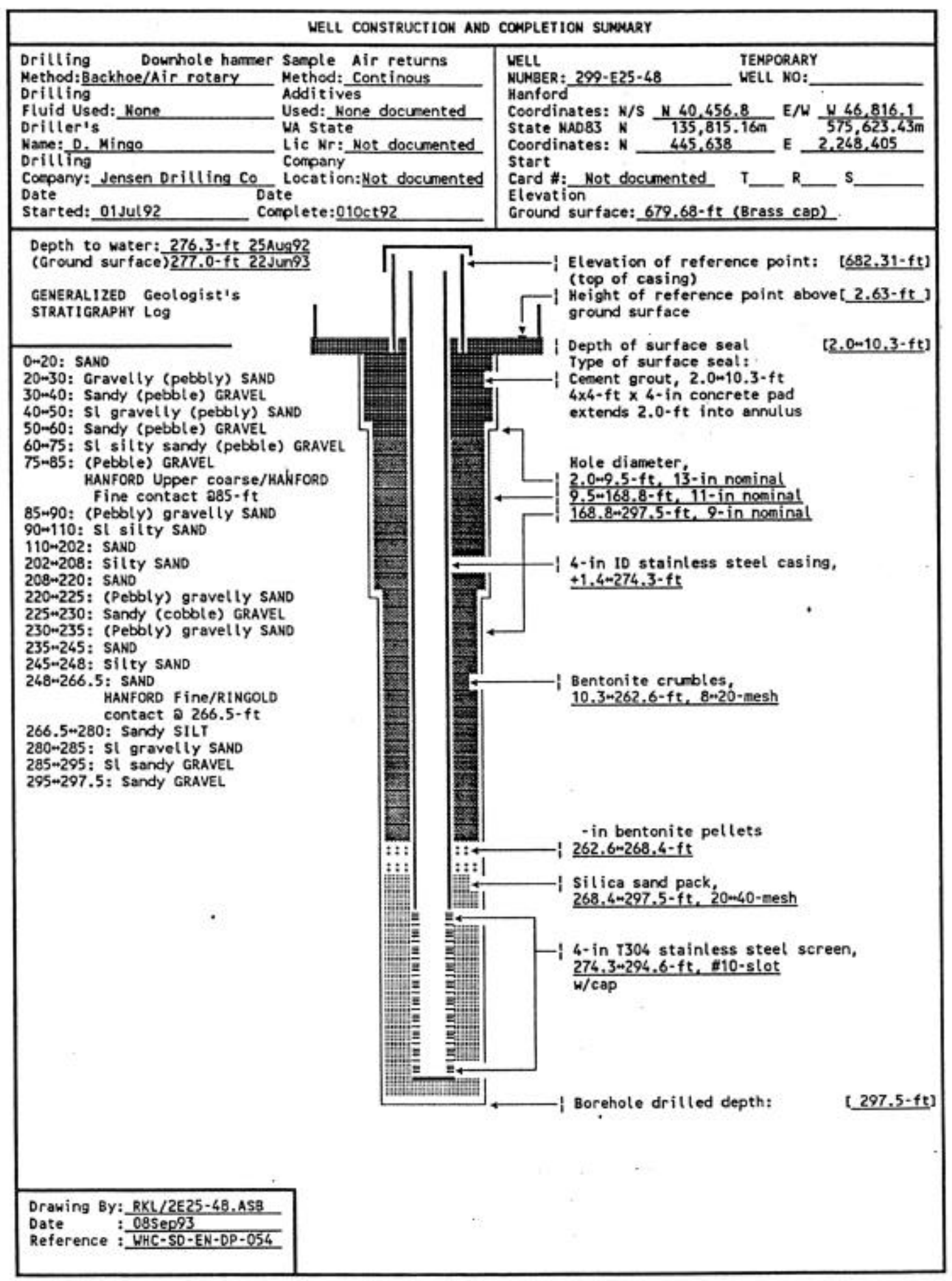




\section{SUMMARY OF CONSTRUCTION DATA AND FIELD OBSERVATIONS \\ RESOURCE PROTECTION WELL - 299-E25-48}

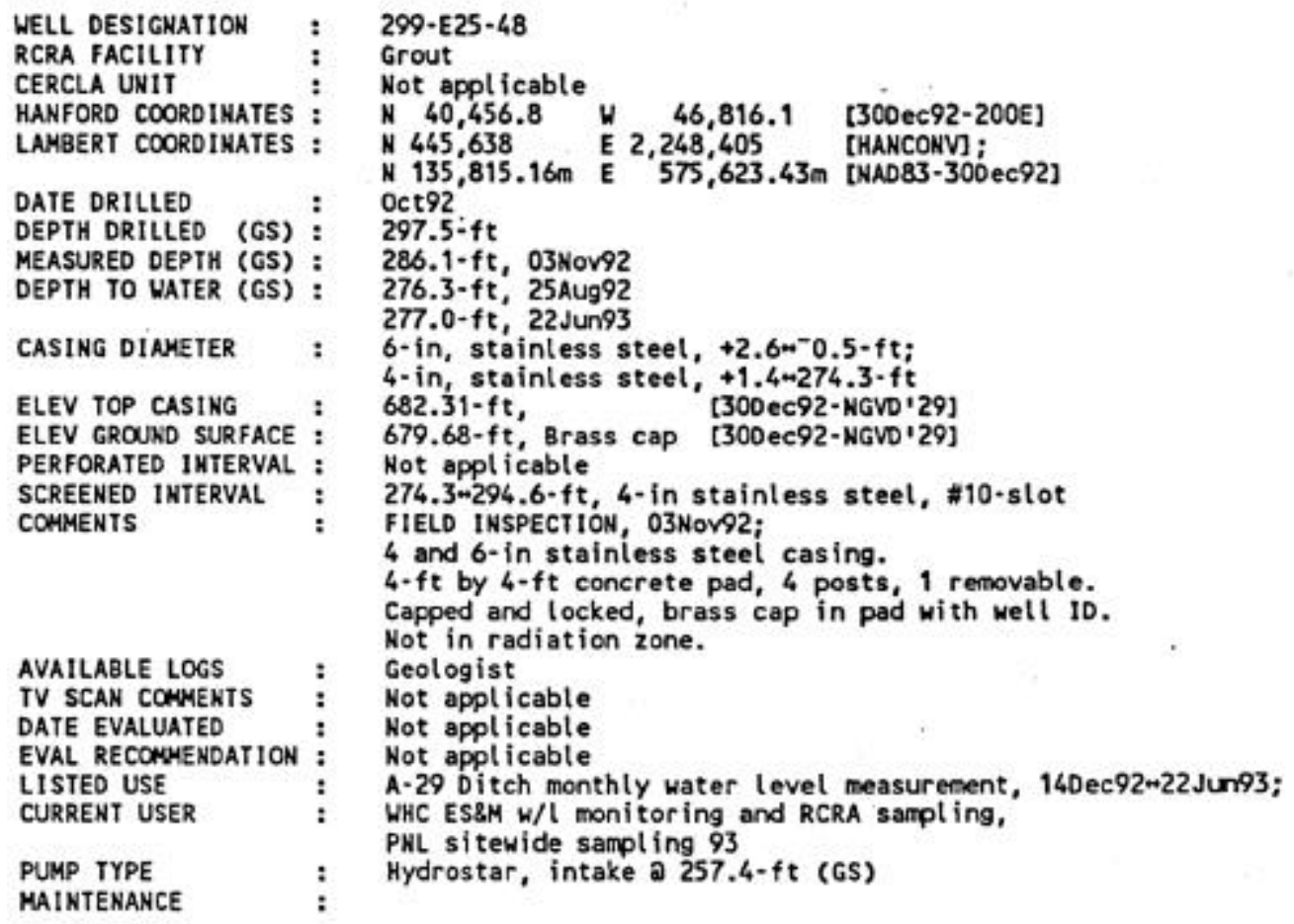




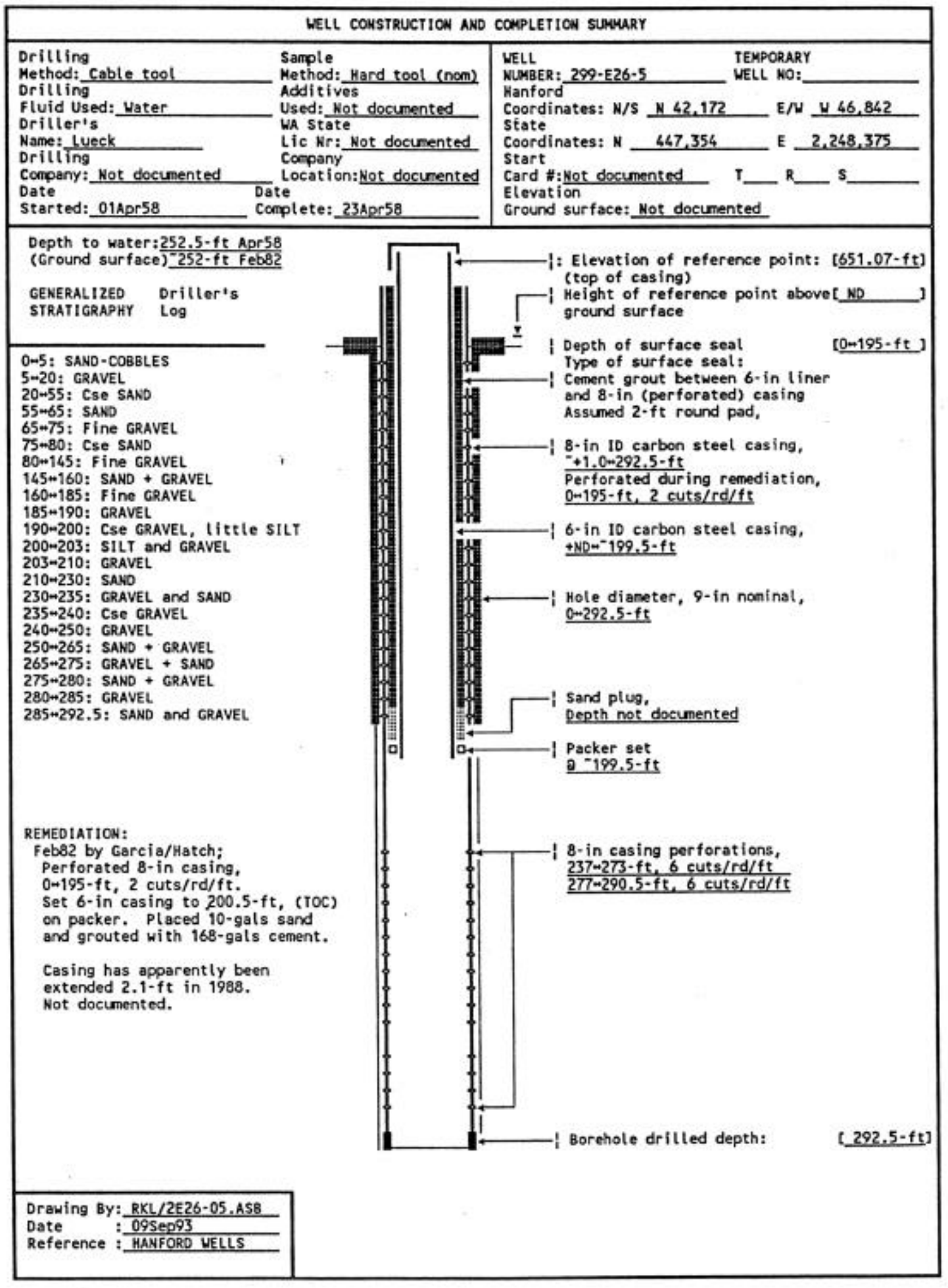




\section{SUMMARY OF CONSTRUCTION DATA AND FIELD OBSERVATIONS RESOURCE PROTECTION WELL - 299-E26-5}

\begin{tabular}{l} 
WELL DESIGNATION \\
RCRA FACILITY \\
CERCLA UNIT \\
HANFORD COORDINATES \\
LANBERT COORDIMATES : \\
DATE DRILLED \\
DEPTH DRILLED (GS) \\
MEASURED DEPTH (GS) \\
DEPTH TO WATER (GS) \\
CASING DIAMETER \\
ELEV TOP CASING \\
ELEV GROUND SURFACE : \\
PERFORATED INTERVAL \\
SCREENED INTERVAL \\
COMMENTS \\
AVAILABLE LOGS \\
TV SCAN COMMENTS \\
DATE EVALUATED \\
EVAL RECOMMENDATION \\
LISTED USE \\
CURRENT USER \\
PUNP TYPE \\
MAINTENANCE \\
\multicolumn{1}{|}{}
\end{tabular}

299-E26-5

Not applicable

200 Aggregate Area Management Study

N 42,172 W 46,842

N 447,354 E $2,248,375$ [HANCONV]

Apr58

$292.5 \cdot \mathrm{ft}$

Not documented

$252.5-\mathrm{ft}$, Apr58

$-252-\mathrm{ft}, \mathrm{Feb82}$

8-in, carbon steel, $+=1.0-292.5-\mathrm{ft}$

6-in, carbon steel, +ND- $-199.5-\mathrm{ft}$

651.07-ft, [210ct88-200E]

Not documented

$0 * 195,237-273$, and $277+290.5-\mathrm{ft}$

Not applicable

FIELD INSPECTIOH,

OTHER: Casing has apparently been extended 4.1- $\mathrm{ft}$ in 1988. Not documented.

Driller

Not applicable

Not appl icable

Not applicable

One water level measurement, 21 Jun88;

None documented

None documented 


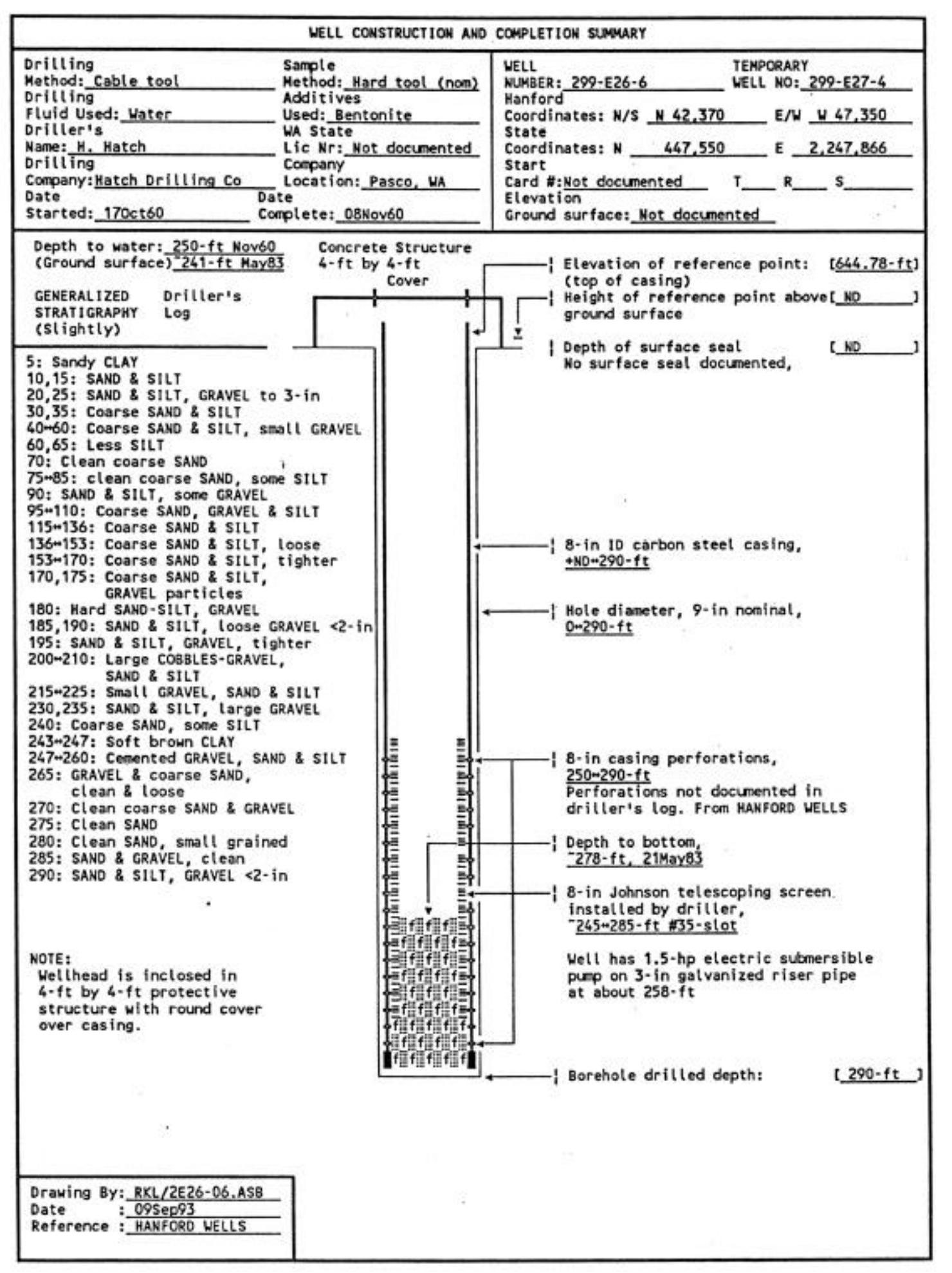




\section{SUMMARY OF CONSTRUCTION DATA AND FIELD OBSERVATIONS RESOURCE PROTECTION WELL - 299-E26-6}

WELL DESIGNATION :
RCRA FACILITY
CERCLA UNIT
HANFORD COORDINATES :
LAMBERT COORDIMATES :
DATE DRILLED :
DEPTH DRILLED (GS) :
MEASURED DEPTH (GS) :
DEPTH TO WATER (GS) :
CASING DIAMETER
ELEV TOP CASING
ELEV GROUND SURFACE :
PERFORATED INTERVAL :
SCREENED INTERVAL :
COMNENTS

AVAILABLE LOGS TV SCAN COHMENTS DATE EVALUATED EVAL RECONHENDATION LISTEO USE CURRENT USER PUMP TYPE MAINTEHANCE
299-E26-6

Not applicable

200 Aggregate Area Management Study

N 42,370 W 47,350

N 447,550 E $2,247,866$ [HANCONV]

Nov60

290- $\mathrm{ft}$

Not documented

$250-\mathrm{ft}$, Nov60

$-241-\mathrm{ft}$, May8

8-in, carbon steel, +ND 290 - ft

644.78-ft

Not documented

$250+290-\mathrm{ft}$

$-245 \mathrm{~m} 285-\mathrm{ft}$

FIELD INSPECTION, 23Mar92,

Inside concrete protective structure, $4-\mathrm{ft}$ by $4-\mathrm{ft}$ by $-1-\mathrm{ft}$.

Structure cover has cap over well casing. Not in radiation zone.

OTHER: Structure has following information written on it:

21May83 - Depth from TOC, 278-ft, 8-in. Static $\mathrm{H}_{2} \mathrm{O}$ level, $242-\mathrm{ft}$.

Screen 243 - ft.

1.5 HP submersible pump, 3-in riser pipe.

Driller

Top-of-pump, $258.5-\mathrm{ft}$.

Not applicable

Not applícable

Not applicable

No water level data

WHC ES\&M operational sampling,

Electric submersible

May83 - Pulled pump, scrubbed screen bailed debris. Reset new electric submersible punp. 


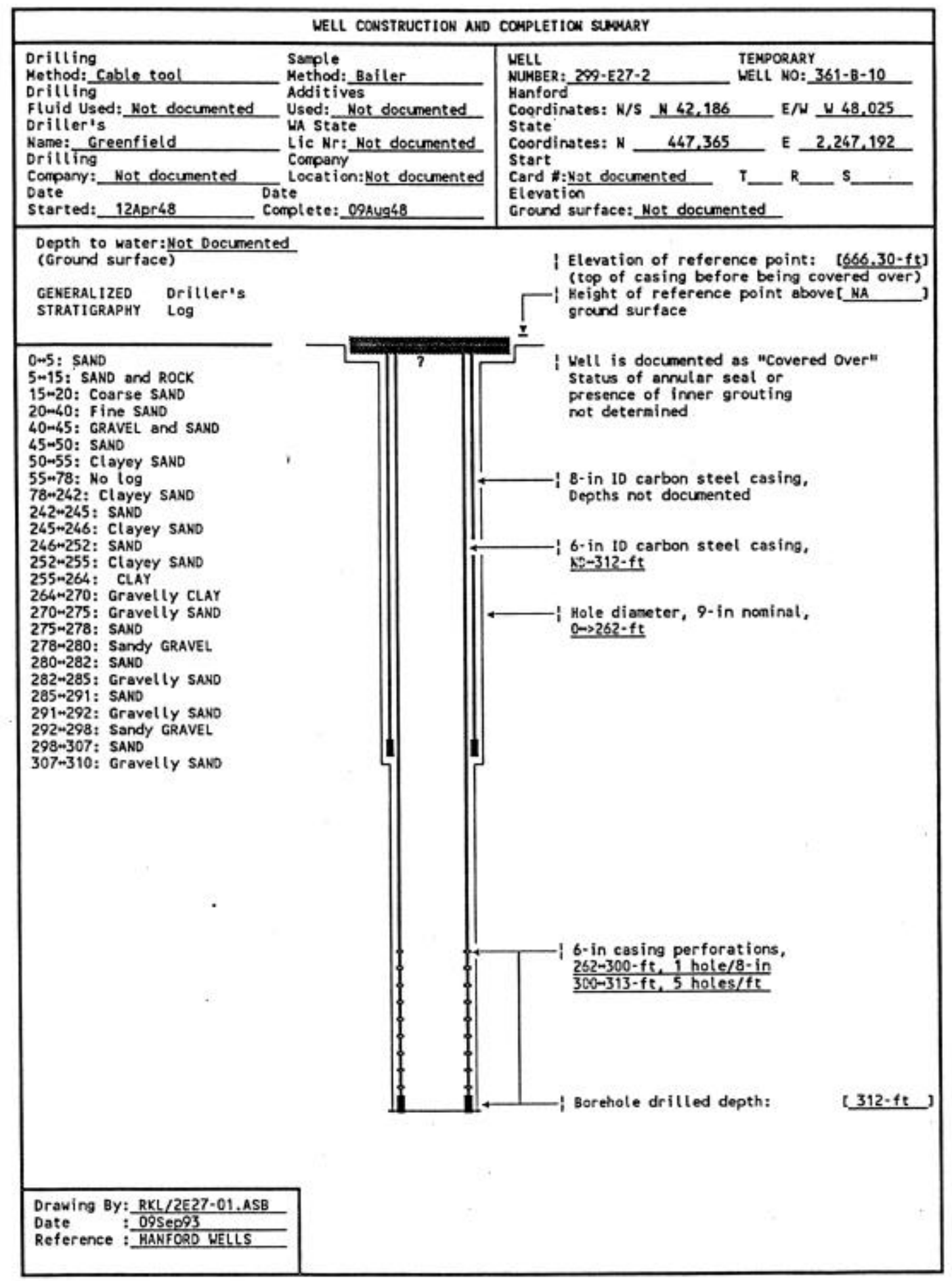




\section{SUMMARY OF CONSTRUCTION DATA AND FIELD OBSERVATIONS RESOURCE PROTECTION WELL - 299-E27-2}

WELL DESIGNATION
RCRA FACILITY
CERCLA UNIT
HANFORD COORDINATES :
LAMBERT COORDINATES :
DATE DRILLED
DEPTH DRILLED (GS) :
MEASUREO DEPTH (GS) :
DEPTH TO WATER (GS) :
CASING DIAMETER
ELEV TOP CASING
ELEV GROUND SURFACE :
PERFORATED INTERVAL :
SCREENED INTERVAL
COMMENTS
AVAILABLE LOGS
TV SCAN CONMENTS
DATE EVALUATED
EVAL RECOMMENDATION :
LISTED USE
CURRENT USER
PUNP TYPE
MAINTENANCE

299-E27-2

Not appl icable

200 Aggregate Area Management Study

N 42,186 W 48,025

N 447,365 E 2,247,192 [HANCONV]

Aug 48

312- $\mathrm{ft}$

Not documented

Not documented

8-in, carbon steel, ND-ND- $\mathrm{ft}$;

6-in, carbon steel, +MD $-312-\mathrm{ft}$

666.30- $\mathrm{ft}$ before being covered over

Not documented

262*312-ft

Not appl icable

Well is documented as covered over

Driller

Not appl icable

Not applicable

Not applicable

No water level data

None documented

None documented 


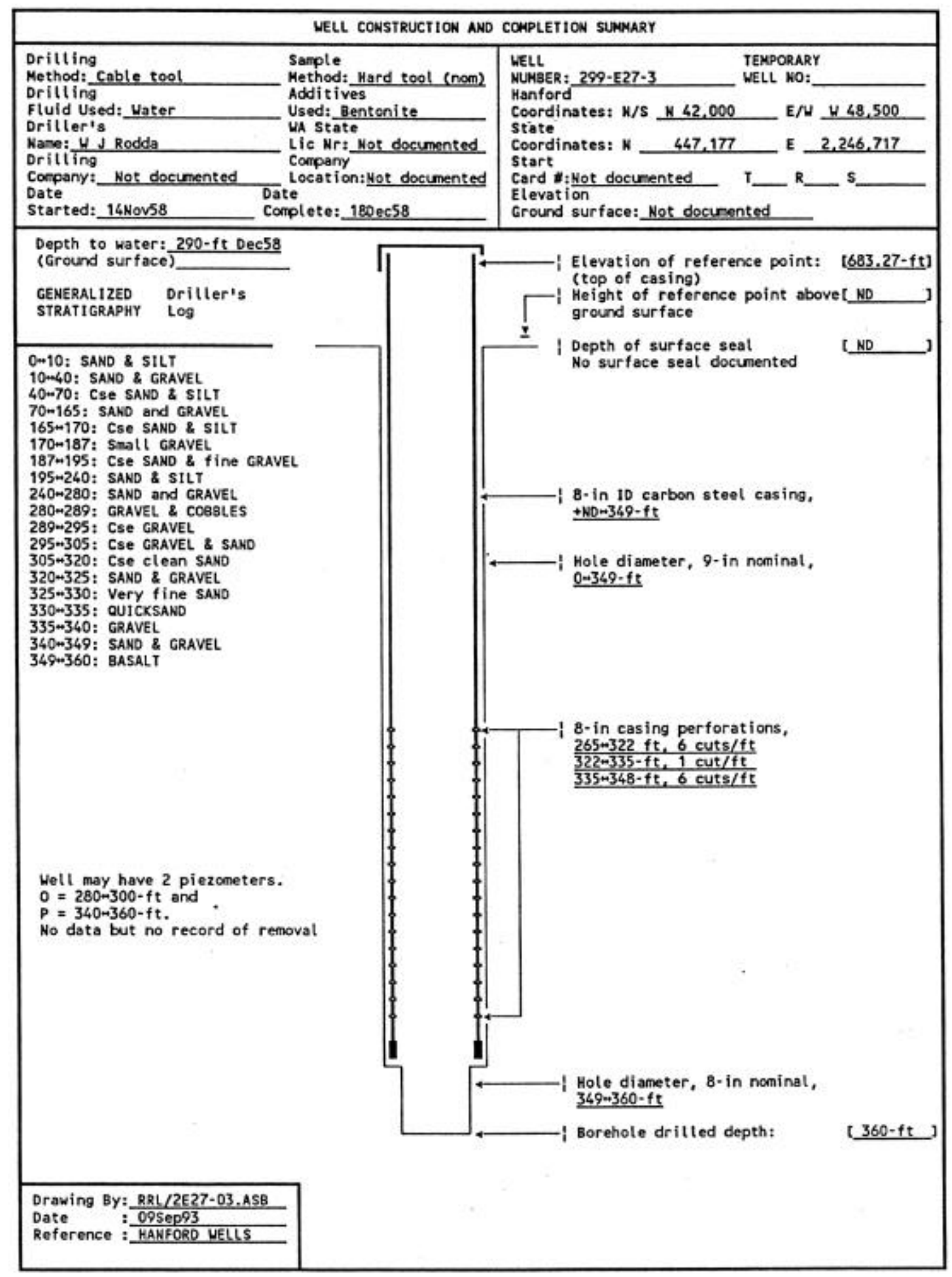




\section{SUMMARY OF CONSTRUCTION DATA AND FIELD OBSERVATIONS RESOURCE PROTECTION WELL - 299-E27-3}

WELL DESIGNATION
RCRA FACILITY
CERCLA UNIT
HAHFORD COORDINATES :
LAMBERT COORDINATES
DATE DRILLLD
DEPTH DRILLED (GS)
MEASURED DEPIH (GS)
DEPTH TO WATER (GS)
CASING DIAMETER
ELEV TOP CASI IKG
ELEV GROUND SURFACE
PERFORATED INTERVAL
SCREENED INTERVAL
CONMENTS
AVAILABLE LOGS
TV SCAN COMMENTS
DATE EVALUATED
EVAL RECOMMENDATION :
LISTED USE
CURRENT USER
PUMP TYPE
MAINTEMANCE

299-E27-3

Not applícable 200 Aggregate Area Management Study

N 42,000

Dec58

$360-\mathrm{ft}$

Not documented

290- ft, 170 ec58

8-in, carbon steel, +ND+349-ft.

$683.27-\mathrm{ft}$,

Not documented

$265 \cdot 348-\mathrm{ft}$

Not applicable

FIELD INSPECTION,

OTHER; May contain two piezometers.

Driller

Not applicable

Not applicable

Not applicable

Water levels measured 28Sep60m010ec82, None documented

None documented 


\section{Appendix D}

Sampling and Analysis Plan 


\section{Appendix D}

\section{Sampling and Analysis Plan}

This appendix consists of a description of the statistical method used for data evaluation, the field sampling plan (FSP), and the quality assurance project plan (QAPP). The t-test required to calculate the critical means is provided in Table 4.1. The FSP specifies the location of procedures guiding sample and field data collection. The Sampling Services Procedure Manual (WMFS 1998) includes the procedures and project management controls intended to ensure the analyzed data and associated measurement errors meet the quantitative and qualitative needs of the groundwater monitoring program at Waste Management Area (WMA) A-AX. Together these documents form the Sampling and Analysis Plan (SAP). The SAP is used as a principal controlling document for conducting the work identified in Section 4.3.

Activities identified in Section 4.3.4 that relate to compliance issues are not currently included in the SAP. Prior to commencement of the tasks required to bring WMA A-AX into compliance with 40 CFR 265, Subpart F, and by reference of Washington State Administrative Code (WAC) 173-303-400 (3), a well installation plan will be developed with a work plan and schedule to guide implementation of these tasks.

\section{D.1 Statistical Methods}

The goal of RCRA detection monitoring is to determine if WMA A-AX has affected groundwater quality. This is determined based on the results of a statistical test. According to 40 CFR 265.92 (and by reference of WAC 173-303-400[3]) the owner/operator of an interim-status hazardous waste facility must establish initial background concentrations for the contamination indicator parameters: specific conductance, $\mathrm{pH}$, total organic carbon, and total organic halogen. This has been done for WMA A-AX by obtaining at least four replicate measurements for each parameter from each well quarterly for 1 year. Data from the upgradient well(s) were used to determine the initial background arithmetic mean and variance.

Monitoring data collected after the first year are compared with the initial background data to determine if there is an indication that contamination may have occurred. A t-test is required to make this determination (40 CFR 265.93[b]). A recommended method is the averaged replicate t-test method described in Appendix B of the RCRA Groundwater Monitoring Technical Enforcement Guidance Document (EPA 1986b). The averaged replicate t-test method for each contamination indicator parameter is calculated as:

$$
\mathrm{t}=\left(\overline{\mathrm{x}}_{1}-\overline{\mathrm{x}}_{\mathrm{b}}\right) / \mathrm{S}_{\mathrm{b}} * \sqrt{1+1 / \mathrm{n}_{\mathrm{b}}}
$$


where $\mathrm{t}=$ test statistic

$\overline{\mathrm{X}}_{\mathrm{i}}=$ average of replicates from the $\mathrm{i}^{\text {th }}$ monitoring well

$\overline{\mathrm{x}}_{\mathrm{b}}=$ background average

$\mathrm{S}_{\mathrm{b}}=$ background standard deviation

$\mathrm{n}_{\mathrm{b}}=$ number of background replicate averages.

A test statistic larger than the Bonferroni critical value, $t_{c}$, (i.e., $t>t_{c}$ ) indicates a statistically significant probability of contamination. These Bonferroni critical values depend on the overall falsepositive rate required for each sampling period (i.e., $1 \%$ for interim status), the total number of wells in the monitoring network, and the number of degrees of freedom $\left(\mathrm{n}_{\mathrm{b}}-1\right)$ associated with the background standard deviation. Because of the nature of the test statistic in the above equation, results to be compared to background do not contribute to the estimate of the variance. The test can be reformulated, without prior knowledge of the results of the sample to be compared to background (i.e., $\overline{\mathrm{x}}_{\mathrm{i}}$ ), in such a way that a critical mean, CM, can be obtained:

$$
\begin{aligned}
& \mathrm{CM}=\overline{\mathrm{x}}_{\mathrm{b}}+\mathrm{t}_{\mathrm{c}} * \mathrm{~S}_{\mathrm{b}} * \sqrt{\left(1+1 / \mathrm{n}_{\mathrm{b}}\right)} \text { (one tailed) } \\
& \mathrm{CM}=\overline{\mathrm{x}}_{\mathrm{b}} \pm \mathrm{t}_{\mathrm{c}} * \mathrm{~S}_{\mathrm{b}} * \sqrt{\left(1+1 / \mathrm{n}_{\mathrm{b}}\right)} \text { (two tailed) }
\end{aligned}
$$

If downgradient data exceed the $\mathrm{CM}$, they are determined to be statistically different from background. For pH, a two-tailed CM (or critical range) is calculated and downgradient data beyond the range are considered to be statistically different from background. If a statistical exceedance is detected, the well will be resampled to determine if the originally detected increase (or $\mathrm{pH}$ decrease) was a result of laboratory or measurement error (verification sampling). If verification sampling confirms the exceedance, the owner/operator must notify Ecology within 7 days and submit a groundwater quality assessment plan within 15 days following the notification (40 CFR 265.93[d]). The goal of the assessment monitoring program is to determine if dangerous waste or dangerous waste constituents from the facility have entered the groundwater and, if so, to determine their concentration and the rate and extent of migration in groundwater (40 CFR 265.93[d]). Critical mean values for WMA A-AX are presented in Table 4.1 in Section 4.3.3.

\section{D.2 Field Sampling Plan}

Sampling and analyses for the WMA A-AX is part of the Hanford Groundwater Monitoring Project. Procedures for groundwater sampling, sample documentation and preservation, shipment, and chain-ofcustody requirements are described in WHC-CM-7-7, and in the project quality assurance project plan (PNNL 1998). Samples are collected after a minimum of three casing volumes of water have been purged from the well and/or after field parameters ( $\mathrm{pH}$, temperature, conductivity, and turbidity) are stable. For routine groundwater samples, labels and preservatives are added to the collection bottles prior to transport 
to the field. Samples to be analyzed for metals are filtered in the field to assure results represent dissolved metals and do not include particulates. Procedures for field measurements are specified in the subcontractor's and/or manufacturer's manuals.

\section{D.3 Quality Assurance Project Plan}

The groundwater monitoring project's quality assurance/quality control (QA/QC) program is designed to assess and improve the reliability and validity of groundwater data. The primary quantitative measures or parameters used to assess data quality are accuracy, precision, completeness, and the method detection limit. The QC parameters are evaluated through laboratory checks (e.g., matrix spikes, laboratory blanks), duplicate sampling and analysis, and analysis of blind standards and blanks. When required, interlaboratory comparisons are made. Acceptance criteria have been established for each of these parameters (PNNL 1998), based on guidance from the U.S. Environmental Protection Agency (OSWER-9950.1; EPA 1986a). When a parameter is outside the criteria, corrective actions are taken to prevent a future occurrence. Affected data are either rejected with a reanalysis of the sample or flagged in the database as suspect.

Furthermore, the data undergo a validation/verification process according to a documented procedure in the Hanford Groundwater Monitoring Project QAPP. Quality control data are evaluated against criteria provided in the QAPP. In addition, the project scientist for WMA A-AX, who has specific site knowledge of historic chemical trends, the facility operations, and the local hydrogeology, screens the data. If the data are suspect, the lab is requested to check calculations and/or reanalyze the sample. Suspect data are either rejected with the reanalysis value or flagged in the database. If after reanalysis, the data are still questionable and pertain to exceedences in the DWS, a new sample is collected and analyzed.

Qualitative measures include representativeness and comparability. For this groundwater monitoring program, the location of the wells with respect to WMA facilities, with respect to groundwater flow direction and rate and the interwell spacing address the goal of acquiring representative samples. In addition, the materials used in well construction, the well construction design, and the length of the screened interval are designed to provide samples representative of groundwater conditions in the uppermost aquifer under the WMA. The sampling frequency is also examined with each sampling event to assure adequacy to detect changes in groundwater quality occurring across the site. Sampling techniques are addressed in the FSP in Appendix D.2. Analysis techniques are specified in contracts with the analytical laboratories used by the Hanford Groundwater Monitoring Project. Most techniques are standard methods from Test Methods for Evaluating Solid Wastes, Physical/Chemical Methods (EPA 1986a). Alternative procedures meet the guidelines of SW-846, Chapter 10. Analytical methods are described in Gille spie (1999). 
Comparability is the confidence with which one data set can be compared to another. The degree to which this can be accomplished depends upon the degree to which the data are accurate, precise, complete, and representative of the groundwater conditions at the WMA. When comparisons between data sets indicate data may be problematic, the data validation/verification process is followed until comparisons can be made with confidence.

\section{D.4 References}

40 CFR 265, Code of Federal Regulations, Title 40, Part 265. Interim Status Standards for Owners and Operators of Hazardous Waste Treatment Storage and Disposal Facilities.

Gillespie, B. M. 1999. “Analytical Methods,” Appendix C of Hanford Site Groundwater Monitoring for Fiscal Year 1998. PNNL-12086, Pacific Northwest National Laboratory, Richland, Washington.

PNNL. 1998. The Hanford Ground-Water Monitoring Project Quality Assurance Project Plan, QA Plan ETD-012, Rev. 1, Pacific Northwest National Laboratory, Richland, Washington.

U.S. Environmental Protection Agency (EPA). 1986a. Test Methods for Evaluating Solid Wastes: Physical/Chemical Methods, $3^{\text {rd }}$ Ed. Office of Solid Waste and Emergency Response, Washington, D.C.

U.S. Environmental Protection Agency (EPA). 1986b. RCRA Groundwater Monitoring Technical Enforcement Guidance Document. Washington, D.C.

WAC 173-303, Dangerous Waste Regulations, Washington Administrative Code, Olympia, Washington (as amended).

WHC-CM-7-7. Westinghouse Hanford Environmental Investigations and Site Characterization Manual. Westinghouse Hanford Company, Richland, Washington. (Current version).

WMFS. 1998. Sampling Services Procedure Manual. ES-SSPM-001. Waste Management Federal Services, Inc. Richland, Washington. 
PNNL-13023

\section{Distribution}

No. of

Copies

\section{OFFSITE}

R. Jim, Manager

Environmental Restoration/

Waste Management Program

Confederated Tribes and Bands of the

Yakama Indian Nation

2802 Main Street

Union Gap, WA 98903

The Honorable W. Burke

Confederated Tribes of the Umatilla

Indian Reservation

P.O. Box 638

Pendleton, OR 97801

P. Sobotta

Nez Perce Tribe

P.O. Box 365

Lapwai, ID 83540

P. Rogers

Jacobs Engineering Group, Inc.

3250 W. Clearwater Ave.

Kennewick, WA 99336

S. Van Verst

Washington State Department of Health

Airdustrial Park, Bldg. 5

Olympia, WA 98504

\section{U.S. Environmental Protection Agency \\ D. Faulk \\ B5-01}

No. of

Copies

4 Washington State Department of Ecology
J. A. Caggiano
B5-18
S. L. Dahl
B5-18
D. N. Goswami
B5-18
A. D. Huckaby
B5-18

\section{ONSITE}

\section{Bechtel Hanford, Inc.}

B. Ford

H0-19

4 CH2M Hill Hanford Group, Inc.
J. Hebdon
R1-51
A. J. Knepp
$\mathrm{H} 0-22$
F. M. Mann
$\mathrm{H} 0-22$
D. A. Myers
$\mathrm{H} 0-22$

10 DOE-Richland Operations Office
C. E. Clark (3)
A5-15
M. J. Furman
A5-13
J. B. Hall
A2-15
R. D. Hildebrand
A5-13
R. W. Lober
H6-60
K. M. Thompson
A5-13
R. Yasek
H6-60
Public Reading Room
$\mathrm{H} 2-53$

13 Pacific Northwest National Laboratory

$\begin{array}{ll}\text { C. J. Chou } & \text { K6-81 } \\ \text { F. N. Hodges } & \text { K6-81 } \\ \text { D. G. Horton } & \text { K6-81 } \\ \text { V. G. Johnson } & \text { K6-96 } \\ \text { S. P. Luttrell } & \text { K6-96 } \\ \text { S. M. Narbutovskih } & \text { K6-96 } \\ \text { Information Release Office (7) } & \text { K1-06 }\end{array}$

Distr.1 